$\Rightarrow$ 政器

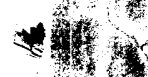
ats

औ 4. औ? 16

As<smiles></smiles>
. W. H2 E* a 4 (3)

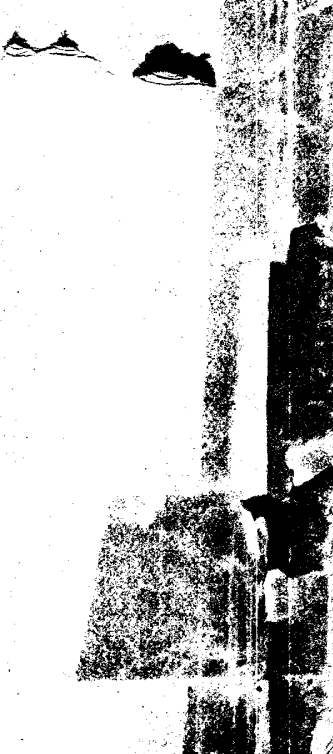
Wry \% , 


\section{CONTENTS}

Abstract.

Introduction

Location and extent of the area....................

Previous geologic work . . . .

Field work

1 Laboratory work

Acknowledgments

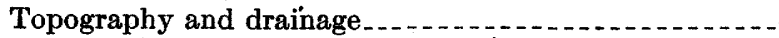

Structure

Major features ...

Minor features...........

Age of folding . . . .

Stratigraphy $\ldots \ldots \ldots$

Lithologic terms used ...............................

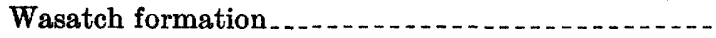

Green River formation . .

Age

Lithology _... . . . .

Rocks east of Bitter Creek, Utah........

Douglas Creek member..........

Garden Gulch member. ..........

Parachute Creek member............

Evacuation Creek member..........

Delta and shore facies.............

Columnar sections .................

Rocks west of Bitter Creek, Utah........

Duchesne-Uintah county line section

Gate Canyon section . . . . .

Indian Canyon section..............

Correlation of facies and zones in Uinta and

Piceance Creek Basins..............

Bridger formation

Lower beds.....

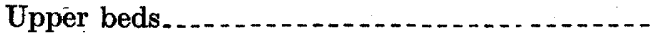

Relations of the Tertiary formations in the Uinta Basin .

The oil shale

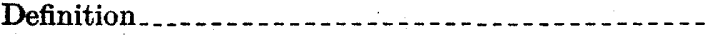

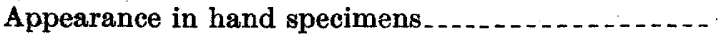

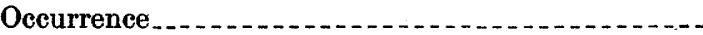

Sedimentary structure in the oil shale and associated rocks

Major features of bedding ................ Regular beds and their significance..... Lenticular beds and their significance.....

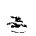

The oil shale-Continued.

Sedimentary structure in the oil shale and associated rocks-Continued.

Minor features of stratification

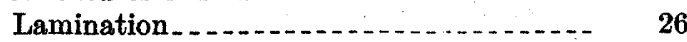

Contorted bedding .

Shale breccias ........................ 28

Mud cracks................ 28

Mineralogy ........................ 29

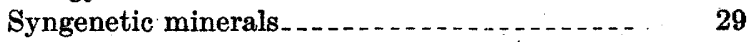

Calcite and dolomite............. 29

Analcite and sepiolite................ 30

Pyrite.......... 30

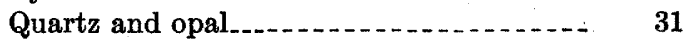

Clastic minerals......................... 31

Saline minerals and their significance $\ldots \ldots . . . \quad 32$

Secondary minerals........................ 36

Concretions....... 37

Calcite concretions

Chert concretions.......... 37

Microfossils _...

Previous similar studies..........

Preparation of thin sections

Appearance of organic matter in thin sections.....-

Flora of the oil shale........................ 40

Bacteria

Fungi......... 40

Algae...... 40

Flagellata............... 41

Cyanophyceae.......................... 41

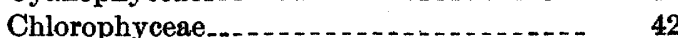

Unclassified forms...................... 44

Bryophyta and Pteridophyta................ 45

Spermatophyta_.......... 46

Gymnospermae.......................... 46

Angiospermae.... 46

Fauna of the oil shale

Protozoa

Sarcodina....... 48

Arthropoda

Arachnida........... 49

Insecta......... 49

Interpretation and significance of the microfossils.-

Structureless organic matter.......................... 52

Phases of Uinta Lake during the Green River epoch.... $\quad 54$

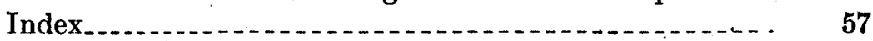

\section{ILLUSTRATIONS}

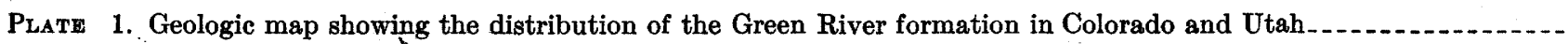

2. $A$, View near Clear Creek, Colo., showing typical cliffs made by the Green River formation; B, Bedding plane of organic marlstone covered with spinose fly larvae.

3. Stratigraphic relations of the subdivisions of the Green River formation in Colorado and Utah.

4. A, View down Piceance Creek, Colo., showing the broken cliffs of the Garden Gulch and Parachute Creek members; $B$, Outcrop of paper shale showing its flexibility

5. $A$, Ellipsoidal salt cavities in Evacuation Creek member; $B$, Close view of cavities formed by radial aggregates of salt crystals 
Plate 6. $A$, Calcite mold of radial aggregate of salt crystals; $B$, Salt crystal cavities suggesting interlocking plates of anhydrite. . . .

7. Columnar section of the Green River formation measured on Parachute Creek, Colo . . . . . . . . . . . .

8. Columnar sections of the Green River formation measured in Trail Creek, Cathedral Creek, Hells Hole Canyon, and White River Canyon, Utah, and north of Deep Channel Creek, Colo . .

9. $A$, Steep false bedding in the muddy sandstone of a delta facies; $B$, View southwest across the valley of Minnie Maud Creek, Utah. .

10. $A$, Differential compaction of oil shale and muddy sandstone; $B$, Mud-cracked organic marlstone bed with small calcite pseudomorphs of a salt filling the cracks .

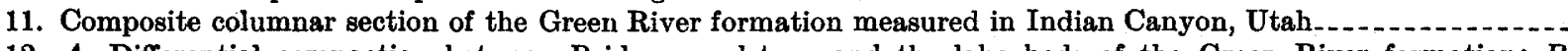

12. $A$, Differential compaction between Bridger sandstone and the lake beds of the Green River formation; $B$, Lower sandy part of Bridger formation in Duchesne County, Utah

13. Oil yields of oil-shale beds in the Green River formation

14. $A$, Contorted bedding in a bed of oil shale; $B$, Photomicrograph showing thin regular lamination in a rich oil shale - . -

15. $A$, Mosaic breccia in oil shale; $B$, Distributive thrust faults in a bed of rich oil shale . . . . . . . . . . . . . . .

16. $A$, Oil-shale breccia showing large fragment oriented at angle to bedding; $B$, Coarse shale breccia in fairly rich oil shale.

17. $A$, Photomicrograph of an oil shale showing calcite concretions and lenses; $B$, Oil shale showing loop bedding.-

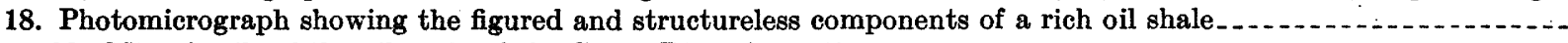

19-28. Microfossils of the oil shale of the Green River formation

FIGORe 1. Index map showing the distribution of the Green River formation

2. Diagram showing the differential compaction at the contact of the Bridger and Green River formations......

3. Columnar section showing distribution of salt mold layers in a part of the Green River formation. 


\section{ABSTRACT}

The Green River formation of Colorado and Utah is a series of lake beds of middle Eocene age that occupy two broad, shallow, simple structural basins-the Piceance Creek Basin, in northwestern Colorado, and the Uinta Basin, in northeastern Utah. It averages about 2,000 feet in thickness but ranges from about 1,200 feet at the north end of the Piceance Creek Basin to about 2,800 feet in the central part of that basin and to a maximum of about 4,900 feet in the western part of the Uinta Basin. In both basins the Green River formation is underlain by beds of sandy mudstone of fluviatile origin that belong to the Wasatch formation. In the Piceance Creek Basin the rocks of the Green River formation are the youngest rocks exposed except in one area, where they are overlain by 400 feet of sandy beds of fluviatile origin that appear to be lithologically and stratigraphically equivalent to the basal beds of the Bridger formation of the Uinta Basin. In the Uinta Basin the Green River formation is conformably overlain by the Bridger formation and that in turn by the Uinta formation, both of which are dominantly of fluviatile origin and consist of mudstone and sandstone.

In this paper the terms "oil shale," "marlstone," "mudstone," "claystone," "siltstone," "shale," and "paper shale" are defined before the lithology of the Green River formation is described. The lithology is treated in two geographic divisions-one east of Bitter Creek, Utah, which is in the eastern part of the Uinta Basin, and the other west of Bitter Creek. East of Bitter Creek the formation has been divided into four members-the Douglas Creek member (at the base), the Garden Gulch member, the Parachute Creek member, and the Evacuation Creek member (at the top). The Parachute Creek member contains most of the rich oil-shale beds and is divided into the lower and upper oil-shale groups, which are separated by a thin unit of relatively barren beds. The upper oil-shale group, which contains the "mahogany ledge," is the principal oil-shale zone of the Green River formation and probably was once continuous from east to west across both basins. At the north end of the Piceance Creek Basin is a thick delta and shore facies that appears to mark the mouth of a large stream that once drained the great lake which lay north of the Uinta Mountains and in which the Green River formation of Wyoming was deposited. West of Bitter Creek, Utah, the Green River formation is not divided into members. In at least two localities it contains thick deltaic facies. In the western part of the Uinta Basin the lower beds interfinger with the Wasatch formation. Locally the contact between the Green River and the overlying Bridger formation has been greatly distorted by differential compaction.

The vertical and horizontal distribution of the oil-shale beds in the Green River formation of Colorado and Utah are discussed, and the appearance of various sorts of oil shale is described. The sedimentary structural features in the oil shale and associated rocks appear to indicate two extremes of conditions under which beds of rich oil shale were formed. The regular beds of great persistence with their thin regular laminae seem to indicate stages when the ancient Lake Uinta was not only relatively broad and deep but also probably thermally stratified, so that the lower stagnant layer of water was favorable to the accumulation of the organic ooze that later became oil shale. The short lenticular beds, the mud cracks, and the shale breccias indicate stages when the water level was low and the organic matter accumulated in more or lesis isolated residual pools. The contortion of the oil shale and associated beds is ascribed chiefly to differential compaction.

Microgranular calcite and dolomite are the predominant mineral constituents of most of the oil-shale beds, but in a few clay minerals belonging to the beidellite group predominate. Analcite, an alteration product of volcanic ash, is plentiful in many beds. In lesser amounts occur either angular fragments or euhedral crystals of quartz, sanidine, orthoclase, plagioclase, muscovite, hornblende, pyroxene, zircon, apatite, and opal and bits of volcanic glass. A large proportion of these came in volcanic ash, and the remainder were brought in by streams. Pyrite is abundant in most beds and indicates that the original organic ooze was a strongly reducing medium wholly analogous to the fetid black organic oozes that are accumulating in certain modern lakes. The mineralogy of two typical oil-shale beds is calculated from chemical analyses. Concretions of microgranular calcite and dolomite and of chert are locally plentiful and appear to have formed soon after the deposition of the ooze. The chert concretions contain finely preserved microfossils. Molds of salt crystals, glauberite(?), and anhydrite(?) are abundant in certain layers of low-grade oil shale or organic marlstone. Calculations based on the distribution of these layers in the thickest saline unit suggest that this unit represents an interval of reduced precipitation or increased evaporation that was of the order of one and a half million years in length, or about one-fourth of the total length of the Green River epoch.

The microfossils of the Green River formation occur locally in beds of unusually rich oil shale and in chert concretions. Thin sections of the chert concretions and of many of the oil-shale samples were ground in the usual way. The remainder of the oil-shale sections were cut with a microtome after the shale had been freed of its mineral matter, softened with phenol, and embedded in paraffin. Two kinds of organic matter are discernible in thin sections of the oil shale; one is massive and structureless and is the matrix of the other, which has definite form and consists of organisms or fragments of them. The microflora of the Green River formation contains two forms that are doubtfully referred to bacteria and many fungi spores, of which 13 are illustrated and compared with living genera. In addition to the spores there are also many fragments of the vegetative parts of fungi. Of the algae, all of which are microscopic, one flagellate, a naked protoplast, five blue-green algae, and five green algae are described and referred tentatively to living genera of fresh-water algae and compared with living species. Five forms, probably all algae, which are too indefinite to be assigned to any position in the natural system are also illustrated and described. According to the numbers of individuals found the blue-green algae appear to have dominated the microflora. No diatoms were found. Of the higher plants spores and pollens are plentiful. Eight spores and three parts of reproductive organs, all probably belonging either to mosses or to ferns; are described. Nine different kinds of pollen are described, and-some of them are compared with the pollen of living plants. A fragment of bark, a part of a spiral tracheid, and a few stellate hairs are the only parts of the tissues of plants higher than the mosses and ferns that have been found. 
The fauna of the oil shale includes rhizopods, insects, and a mite. Three new species of rhizopods, all belonging to living genera, are illustrated and described. Many of the insect remains are fragmentary and include the chitinous integuments of the eyes, the wing scales, and hairs of minute adult insects. Pieces of chitinous skins of dipterous larvae and their isolated spines are the most plentiful insect remains. Complete larvae representing five different families of Diptera are illustrated and discussed, though not described. One predaceous mite belonging to the Chelytidae, probably the first fossil mite to be found in this hemisphere, is also illustrated without systematic description. The abundance of the fungi suggests the possibility that the organic ooze was occasionally exposed to air.

The predominance of microscopic fresh-water algae and Protozoa over the remains of land plants with the exception of pollens and spores suggests that the greater part of the organic matter in the oil shale was derived from microorganisms that grew in the lake and strengthens the analogy between the original organic ooze and the black fetid oozes now accumulating in certain lakes. The pollens and spores were brought into the lake chiefly by wind. Most of the fly larvae, which are found in beds of organic marlstone, appear to indicate rather shallow water.

Most of the structureless organic matter in the Green River oil shale is isotropic, though there are also two anisotropic varieties. The writer concludes that the structureless organic material, which makes up by far the greater part of the total organic matter of the oil shale, was derived from the partial putrefaction of aquatic organisms that grew in the ancient lake. Mechanical and chemical actions, such as the mastication and digestion of the original material by bottom-living organisms, were probably also important factors in the dis- integration of the organic matter. When the organic matter was reduced to a gelatinous condition it apparently resisted further bacterial decay. Other microorganisms accidentally entombed in the gel were completely impregnated with it, supported by it, and so protected from decay or disintegration until the whole mass became lithified. The manner in which the microfossils of the oil shale were preserved is thus somewhat akin to the manner in which the original resins of amber entombed minute organisms and so preserved them.

The ancient Uinta Lake, in which the sediments of the Green River formation of Colorado and Utah accumulated, appears to have had throughout its life an extraordinarily large area compared with its depth. It was probably panshaped, with very gently sloping shores. At first it was large, shallow, relatively stable, and entirely fresh. Later and for the greater part of its life it seems to have fluctuated in volume considerably, having alternately an outlet and then none. During these stages of fluctuating level and restricted discharge the lake water became rich in foodstuffs and the water temperature was generally rather high, and under these optimum conditions enormous quantities of minute aquatic organisms were produced. At many times, however, during this part of the Green River epoch the lake was apparently deep enough for the water to be thermally stratified, and the deposits that accumulated at such times were varied. The stages that followed, in the later part of the epoch, were somewhat less favorable to the growth of aquatic organisms; the concentration of dissolved salts increased, so that in parts of the basin, perhaps isolated from the rest, salt was repeatedly deposited, though never in sufficient quantity to make up continuous beds. After the saline phases the lake was again freshened either by increased rainfall, by diminished evaporation, or by the cutting down of the outlet. 


\title{
ORIGIN AND MICROFOSSILS OF THE OIL SHALE OF THE GREEN RIVER FORMATION OF COLORADO AND UTAH
}

\author{
By W. H. Bradley
}

\section{INTRODUCTION}

The Green River formation offers a rare opportunity for the study of lacustrine sedimentation, for it records with remarkable completeness a varied but essentially unbroken series of events lasting through nearly a third of a geologic epoch. Moreover, it has a great lateral extent, and in that also it is unusual for a lacustrine formation. But its chief claim to interest is the oil shale, whose potential economic value has attracted widespread attention.

Little is known, however, about the geologic history, origin, microstructure, and composition of the oil shale and it is the chief aim of this study to elucidate those aspects. To that end the field relations of the oil shale to the formation as a whole have been studied at many places. in Colorado and Utah which the writer regards as critical to their proper interpretation. The features of sedimentary structure, such as bedding, lamination, contorted bedding, shale breccias, and mud cracks, have revealed much regarding the physical conditions under which the deposits accumulated. In a comparable way the mineralogy of the oil shale has revealed the chemical and to some extent also the physical conditions attending its formation. These physical and chemical criteria, together with the stratigraphy of the region, make it possible to reconstruct a fair picture of the successive phases of the lacustrine history.

Correlated with these data is a remarkably complete biologic record which sheds much light on the physiologic and physiographic ecology of Green River time. The fossils, which include a rather unusual assemblage of forms, are all characterized by the excellence of their preservation. The fish are numerous and famous as museum specimens. Bones of crocodiles and turtles are more common in the shore phases than has been supposed. More than 300 species of insects from different parts of the formation have been described, and many more await study. Ostracodes are exceedingly abundant, but mollusks are rare except in a few of the shore phases. The flora is large and includes not only leaves but flowers, fruits, and seeds and aquatic as well as land plants. Fresh-water algae reefs are plentiful in parts of the formation and help to determine the form ratio of the Green River lakes and their relative stability at certain stages.

Supplementing this large and varied record of the life of the Green River epoch is the remarkable microscopic flora and fauna of the oil shale. These organisms exceed even the megascopic fossils in excellence of preservation. They include many algae, fungi, spores, and pollens and a few rhizopods.

With all this material available it has been possible to reconstruct in some detail the geologic history of the formation as a whole and to draw a fairly complete picture not only of the conditions within the lakes but also of the environment.

\section{LOCATION AND EXTENT OF THE AREA}

The index map (fig. 1) shows the distribution of all of the Green River formation in Colorado, Utah, and Wyoming except some small exposures of lake beds in the vicinity of Juab and Manti, Utah, whose identification with this formation is still uncertain. This report treats in particular certain phases of the formation in Colorado and Utah exclusive of that in Moffat County, Colo., north of the Yampa River, which, together with other specific parts of the formation in Wyoming, has been described elsewhere. ${ }^{1}$

The Green River formation of Colorado and Utah was laid down in the ancient Uinta Lake and now occupies two large, shallow structural basins-the Piceance Creek Basin in Colorado and the Uinta Basin in Utah. A narrow isthmus of the formation connects these two large areas. South of the Colorado River there are two isolated areas of the formation in Battlement and Grand Mesas. The rocks in these mesas were once continuous with those north of Colorado River and indicate a former considerable southward extension of Uinta.Lake.

The area in the Piceance Creek Basin where the Green River formation is now exposed is about 95 miles long from north to south and about 48 miles wide. In the Uinta Basin the formation is exposed in a strip about 135 miles long from east to west and about 46 miles wide at the widest place.

1 Sears, J. D., and Bradley, W. H., Relations of the Wasatch and Green River formations in northwestern Colorado and southern Wyoming: U. S. Geol. Survey Prof. Paper 132, pp. 93-107, 1924. Bradley, W. H., Shore phases of the Green River formation in northern Sweetwater County, Wyoming: U. S. Geol. Survey Prof. Paper 140, pp. 121-131, 1926. 


\section{PREVIOUS GEOLOGIC WORK}

Peale ${ }^{2}$ explored the region between the Colorado and Gunnison Rivers and recognized in Battlement and Grand Mesas the Green River "group," which then included the Green River and Wasatch formations. He expressed the belief of Hayden, Cope, and Marsh that the lakes of the Green River and Uinta Basins were ment Mesa and Thompsons, Utah. White and Endlich ${ }^{4}$ mapped the Uinta, Bridger, Green River, Wasatch, and older formations in the White River drainage basin from a point near Ouray, Utah, to the head of the river. This map is good for the area along the White River but very inaccurate for the side streams. Both White and Endlich ${ }^{5}$ described the

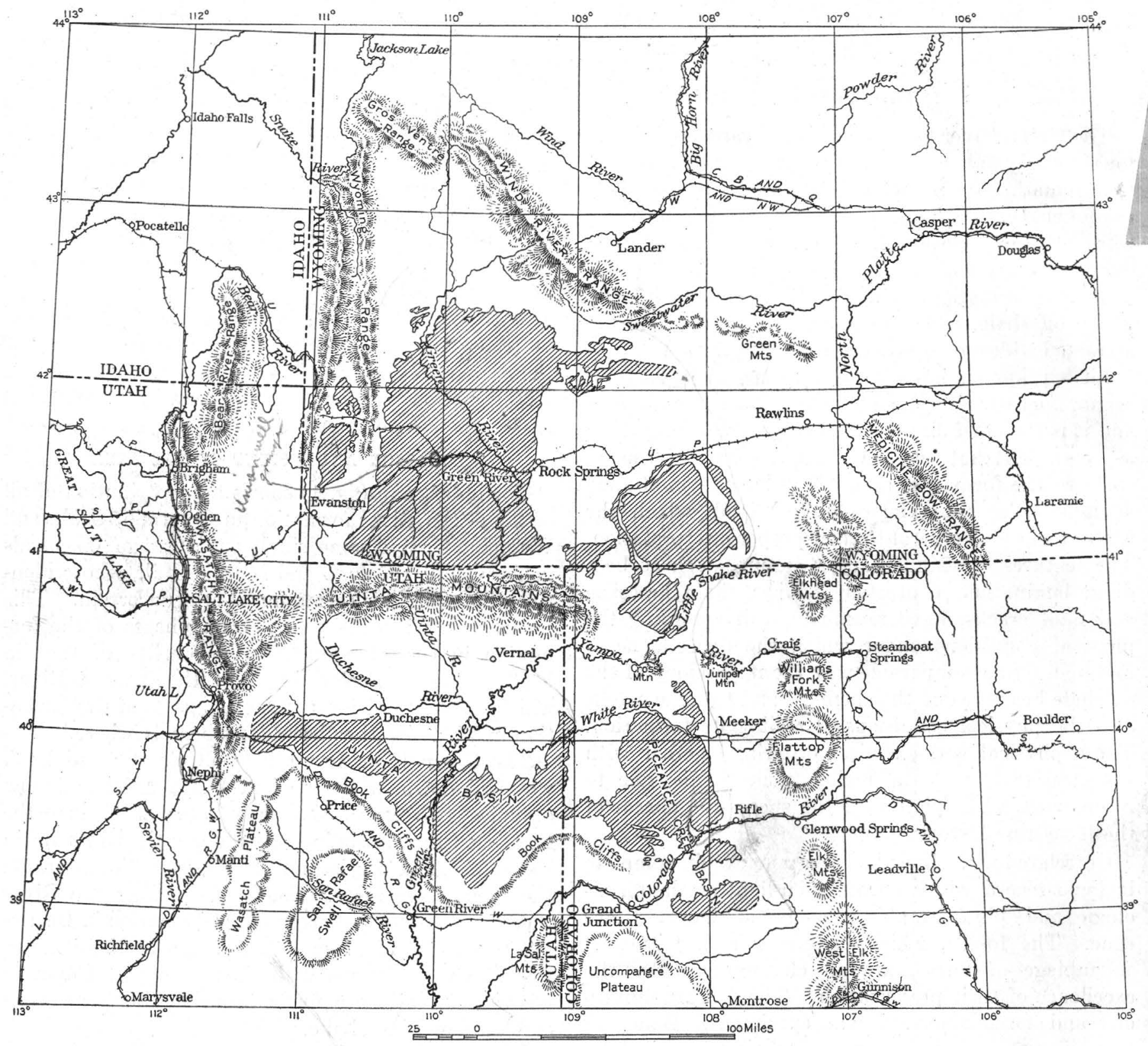

FIGURE 1.-Index map showing the distribution in Colorado, Wyoming, and Utah of the Green River formation (shaded areas). Adapted chiefly from Winchester, D. E., U. S. Geol. Survey Bull. 729, 1923, and the writer's unpublished maps

contemporaneous and probably connected by a river. Two years later Peale made a good reconnaissance map ${ }^{3}$ showing the distribution of the Green River, Wasatch, and older formations in the area drained by the Colorado River and its tributaries between Battle-

2 Peale, A. O., U. S. Geol. and Geog. Survey Terr. Ann. Rept. for 1874, pp.148, 156, 160-161, 1876.

Peale, A. C., U. S. Geol. and Geog. Survey Terr. Ann. Rept. for 1876, pl.11, 1878.
Bridger and Uinta formations. They regarded the thick series of sandstone beds at the base of the Bridger formation in Utah as a part of the Green River formation. Peale ${ }^{6}$ measured several sections of the Green River formation between the head of Roan

4 White, C. A., and Endlich, F. M., idem, pl. 2

3 Idem, pp. 35-37, 82-86.

Idem, pp. 184-185. 


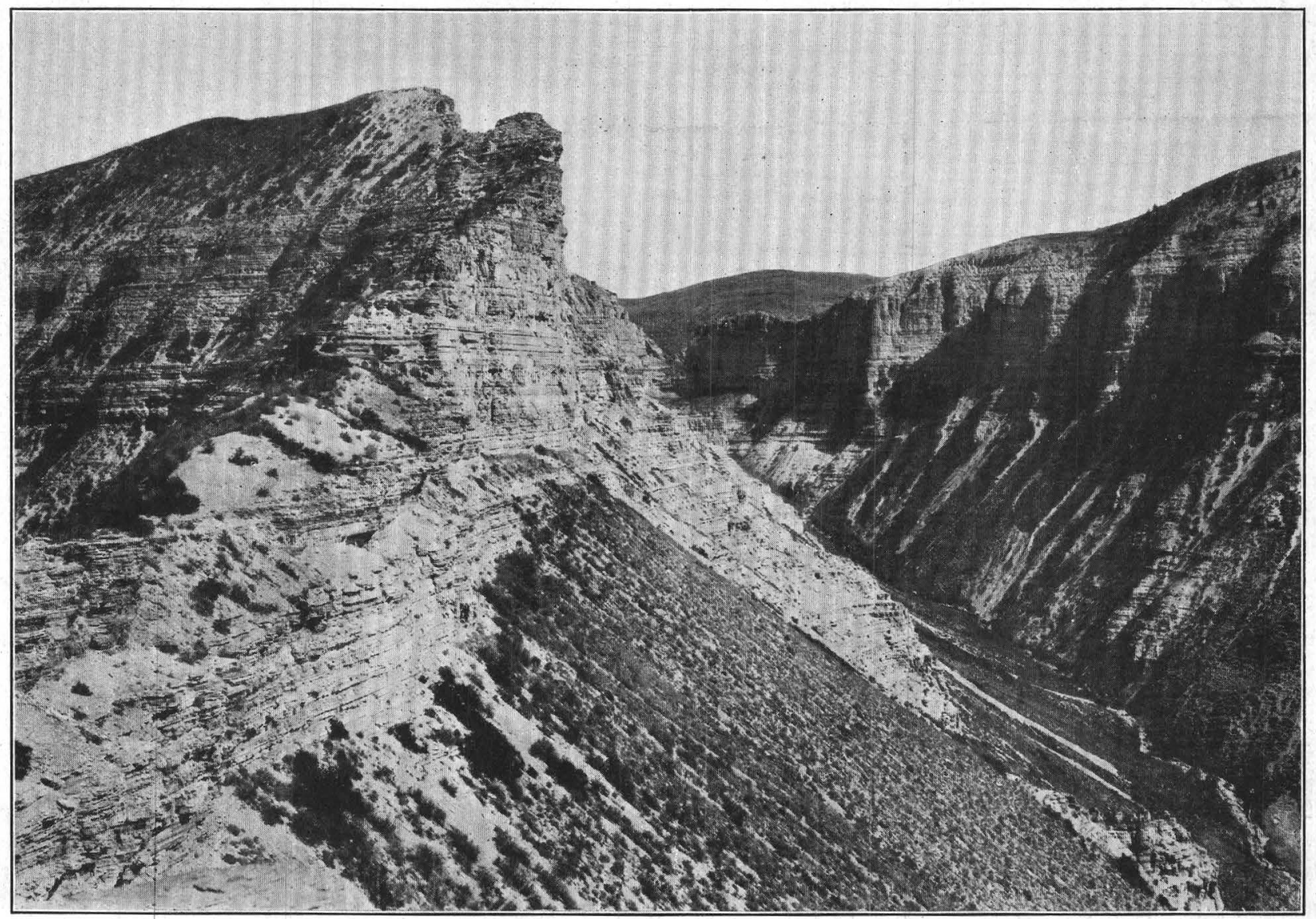

A. VIEW UP A SMALl TRIBUTARY OF ClEAR CREEK, GARFIELD COUNTY, COLO. Shows the typical cliffs made by the principal oil-shale group of the Parachute Creek member of the Green River formation. The photograph was
taken approximately from the horizon of the "mahogany ledge." Photograph by D. E. Winchester.



B. BEDDING PLANE OF BROWN ORGANIC MARLSTONE COVERED WITH LARGE SPINOSE FLY LARVAE, LITHOHYPODERMA SP. 
Creek in Colorado and Bitter Creek in Utah. He also described ${ }^{7}$ several asphalt exudations in association with sulphurous springs in the head of Asphalt Wash.

Many years later Gale ${ }^{8}$ made an excellent reconnaissance map showing a part of the Green River formation along the eastern margin of the Piceance Creek Basin.

In 1913 Woodruff and Day ${ }^{9}$ also made a reconnaissance survey of a part of the area occupied by the Green River formation in Colorado and Utah. In 1914-1917 Winchester ${ }^{10}$ studied the Green River formation in Colorado in considerable detail, mapped not only the base of the formation but also the principal oil-shale zone, measured many stratigraphic sections, especially in the oil-shale zone, and sampled many oil-shale beds. In Utah in 1918 Winchester mapped only the principal oil-shale zones, measured several stratigraphic sections, and sampled the oil shale.

\section{FIELD WORK}

The writer had the opportunity in 1921 but more especially in 1922, while assisting J. D. Sears, of the United States Geological Survey, to map and study the Green River formation in Moffat County, Colo., both north and south of the Yampa River, and in part of southern Sweetwater County, Wyo. In 1923 the writer, assisted by Carle H. Dane, also of the Geological Survey, mapped and studied some shore phases of the formation in northern Sweetwater County. The results of that study have already, been published. ${ }^{11}$ In 1924 the writer spent the first two weeks in June studying samples of the bottom deposits and the plankton of Goose and Klamath Lakes, in southern Oregon. These samples were examined in the field with a portable microscope and studied later in the office with more care. From the middle of June to the end of August, 1924, the writer was assisted by Charles E. Erdmann, of the Geological Survey. During that time most of the Green River formation between the Yampa and White Rivers in Rio Blanco and Moffat Counties, Colo., was mapped, and the conditions of sedimentation in that area, along the White River as far west as Yellow Creek, and also along Piceance and Parachute Creeks were studied. Fossils and specimens were collected particularly from Hay Gulch and Piceance, Yellow, Greasewood, and Parachute Creeks. At the end of that season a few days were spent in examining the Green River formation just north of Watson, Utah.

\footnotetext{
T Peale, A. C., op. cit. (1878), p. 175.

8 Gale, H. S., Coal fields of northwestern Colorado and northeastern Utah: U. S. Geol. survey Bull. 415, p. 83, pls. 10, 18, 1910.

- Woodruff, E. G., and Day, D. T., Oil shale of northwestern Colorado and northeastern Utah: U. S. Geol. Survey Bull. 581, pp. 1-21, 1915.

10 Winchester, D. E., Oil shale. of the Rocky Mountain region: U. S. Geol. Survey Bull. 729, 1923.

11 Bradley, W. H., Shore phases of the Green River formation in northern 8weetwater County, Wyo.: U. 8. Geol. Survey Prof. Paper 140, pp. 121-131, 1926. $36544-31-2$
}

In 1925 the writer and his assistant R. D. Ohrenschall made a stratigraphic study of the Green River formation at six critical localities in the Uinta and Piceance Creek Basins. These localities are shown on Figure 1. At each place a minutely detailed section was measured and a particular search was made for all possible features that would assist in the interpretation of the formation or that would be of value for correlation. Each section, except the one on the north side of Minnie Maud Creek near the DuchesneUintah county line in Utah, is complete, so that the fossil collections and distinctive lithologic facies are accurately located in the formation. In addition to this detailed work they made several reconnaissance trips to other parts of the Uinta and Piceance Creek Basins for comparative study and also spent two days studying the plankton and bottom deposits of Little Salt Lake, near Parowan, Utah. The field work on the Green River formation began that year July 15 and lasted until the end of September.

\section{IABORATORY WORK}

Several years ago Charles A. Davis, late of the United States Geological Survey and the United States Bureau of Mines, began to study the microscopic fossils found in the oil shale of the Green River formation. He developed a fine technique in preparing the material for study, but his untimely death left this work incomplete, and so far as the writer is aware none of the microorganisms were ever described and only a few were identified. In 1922 the writer undertook to expand and complete this study, and since then about half of each winter has been devoted to a microscopic study of the oil shale. Particular emphasis has been placed upon the description and classification of the microfossils and an inquiry into their significance in the origin of the oil shale. Much of the remainder of the writer's time in the office has been spent in a study of the literature relating not only to the origin of oil shale and related sedimentary rocks but also to limnology and hydrobiology. The results of recent work on organic lacustrine ooze have been very useful in the interpretation of oil shale.

The Davis collection of more than 160 thin sections and 176 photomicrographs formed the nucleus with which the writer began the study of the microfossils found in the Green River oil shale. No notes of any kind accompanied this material, many of the thin sections were either unlabeled or marked with symbols that had no meaning, and all the photomicrographs were unlabeled except a few of pollens and spores and one alga, which was erroneously labeled Spirulina sp. Later some specimens were found whose envelopes bore a description together with the letter symbols of the locality from which came the material richest in microfossils. All of Davis's photomicrographs repre- 
sent specimens from this one locality. Subsequent study by the writer has considerably enlarged the collection of thin sections and photomicrographs.

\section{ACKNOWLEDGMENTS}

To David White belongs the full credit for pointing out that much of the oil shale of the Green River formation was derived from sapropel which accumulated in more or less saline playa-like lakes. The writer's paper that appeared in April, 1925, ${ }^{12}$ was intended simply as a discussion of Henderson's paper on the origin of the Green River formation. ${ }^{13}$ It was prepared and had been accepted for publication before the writer had any knowledge of the contents of White's discussion of the origin of the Green River formation which was at that time in press and which appeared in April, 1926. ${ }^{14}$ The writer is much indebted to $\mathrm{Mr}$. White for his guidance during the early stages of this work and for his many stimulating suggestions during its progress.

The writer wishes also to express his thanks to Prof. Gilbert M. Smith, of Leland Stanford Junior University, who criticized that part of the report which discusses the algae and who gave very valuable advice on the taxonomy of these forms. Drs. C. L. Shear and A. C. Longley, both of the Bureau of Plant Industry, United States Department of Agriculture, have also helped the writer greatly. Doctor Shear examined many of the fungus spores and photomicrographs of them, and his suggestions regarding their possible relationships with living fungi have been incorporated in the writer's brief descriptive notes on those crypto: gams. Doctor Longley examined some of the writer's photomicrographs of pollens and suggested pertinent literature that would assist in classifying them. Dr. H. G. Dyar, of the United States National Museum, was kind enough to examine some of the eyes of minute adult insects which have been found in the oil shale.

Dr. Charles T. Greene, of the Bureau of Entomology, has taken a keen interest in the fossil dipterous larvae which the writer has collected. He has made a careful study of the best specimens in the collection and determined to what families and genera several of them belong. It is hoped that he will sometime be able to publish descriptions of some of these larvae.

The writer is indebted to Prof. Carl O. Dunbar, Prof. Adolph Knopf, and Dr. R. W. Brown, of Yale University, who read the manuscript and offered helpful criticisms. This report in essentially its present form was presented as a thesis in partial fulfillment of the requirements for the degree of doctor of philosophy at Yale University in June, 1927.

12 Bradley, W. H., A contribution to the origin of the Green River formation and its oil shale: Am. Assoc. Petroleum Geologists Bull., vol. 6, pp. 247-262, 1925.

13 Henderson, Junius, The origin of the Green River formation: Am. Assoc. Petroleum Geologists Bull., vol. 8, pp. 662-668, 1924.

14 Twenhofel, W. H., Treatise on sedimentation, pp. 289-304, 1926.
Finally, the writer is grateful to his colleagues of the Geological Survey. W. W. Rubey gave considerable time to a thorough criticism of the manuscript, and both he and C. H. Dane have, from time to time during the course of the work, offered many helpful suggestions.

\section{TOPOGRAPHY AND DRAINAGE}

That part of the Green River formation described in this report makes conspicuous highlands in central portions of a large intermontane basin inclosed by the Uinta Mountains on the north; the Williams Fork, Flattop, Elk, and West Elk Mountains on the east; remotely by the La Sal Mountains, Uncompahgre Plateau, and San Rafael Swell on the south; and the Wasatch Mountains on the west. Because the G:een River formation is resistant to erosion these central highlands have in most places high and steep outwardfacing escarpments.

Between the Colorado and Gunnison Rivers the rocks of the Green River formation make two high steep-sided tablelands, Battlement and Grand Mesas. The top of each mesa is about 10,000 feet above sea level, and between the highest point on Battlement Mesa and the Colorado River near Rifle there is a difference in altitude of about 5,500 feet. Between the White and Colorado Rivers the formation makes a large plateau, which has a small extension north of the White River, known as the Gray Hills. This large plateau is entirely surrounded by bold outwardfacing bluffs. Along the south side, in the Colorado River Valley they are 3,000 to 4,000 feet high. On the east and west sides the slopes are precipitous but not so high, and those along the White River are still lower, rising 1,200 feet or less from the river level. The extension of the plateau north of the White River is also bounded by precipitous slopes from several hundred to 1,000 feet high. The surface of the entire plateau slopes gently inward from the high rim toward the center of the basin.

The Green River formation in Utah makes a high monoclinal ridge, 8,000 to 10,000 feet above sea level, that extends from the Colorado line westward nearly to Soldier Summit. This ridge lies north of and roughly parallels the Book Cliffs and forms the southern rim of the Uinta Basin. The south side of the ridge is generally very steep, but the north side is a gentle dip slope. The Green River formation is exposed from this rim north approximately to the Duchesne and White Rivers. This high country comprises the East Tavaputs Plateau, east of the Green River, and the West Tavaputs Plateau west of the river.

All the streams that flow over the rocks of the Green River formation have cut narrow, steep-sided valleys or deep canyons with precipitous walls. The upper parts of the streams that run into the Colorado River flow for several miles in hanging valleys. Short but 
deep box canyons are characteristic of the streams draining the Green River formation. (See pl. 2, A.)

Most of the area of the formation in Colorado and Utah is drained by the Green River through either the Duchesne River or the White River. A part of the West Tavaputs Plateau is drained directly by short side streams of the Green River. In Garfield County, Colo., most of the area of the Green River formation is drained by short tributaries to the Colorado River.

The major streams of the region once flowed at higher levels on younger Tertiary rocks that covered this region, but they have since cut down through these rocks. They are not yet influenced by the structure of the older Tertiary and Mesozoic rocks through which they now flow, but their tributaries, especially in the Uinta Basin, seem to be well adjusted to the structure. (See pl. 1.) The tributaries to the Colorado River that drain parts of the Green River formation, on the contrary, are not at all adjusted to the structure and are cutting back into high divides whose rocks dip away from the heads of the streams.

\section{STRUCTURE \\ MAJOR FEATURES}

The structure of the Green River formation of Colorado and Utah is simple. The formation occupies two large shallow basins-The Piceance Creek Basin in Colorado and the Uinta Basin in Utah. These are separated by a low anticlinal arch whose axis is roughly parallel to the Utah-Colorado boundary line and about 15 miles east of it.

In the southern part of the Piceance Creek Basin and in the extensions in Battlement and Grand Mesas the beds dip very slightly toward the north, usually at angles of less than $1^{\circ}$. On the west side of the basin the dips range between $1^{\circ}$ and $2^{\circ} \mathrm{E}$. near the head of Roan Creek and $7^{\circ}$ or $8^{\circ} \mathrm{E}$. or SE. near the White River. The earth movements that tilted up steeply the rocks of the Grand Hogback also affected the Green River beds along the eastern margin of the Piceance Creek Basin, where they dip $15^{\circ}-27^{\circ} \mathrm{W}$. However, the beds flatten abruptly basinward and a few miles from the rim dip $5^{\circ}$ or less toward the west. Along the south side of the White River the rocks dip $5^{\circ}-12^{\circ} \mathrm{S}$., but there also they flatten basinward a little way from the rim.

North of the White River the Green River formation occupies a shallow and irregular syncline that ends at the north against the flank of Cross Mountain, a. dome on the eastward extension of the Uinta Mountain arch. Along the east side of this syncline the dips range from $4^{\circ}$ to $23^{\circ}$, generally west, but on the west side they are less steep, usually $1^{\circ}-6^{\circ} \mathrm{E}$.

In the Uinta Basin the rocks of the Green River formation are everywhere gently inclined except for a short distance along Raven Ridge, just west of Rangely, Colo., where they dip as much as $22^{\circ} \mathrm{SW}$.
All across the southern rim of the Uinta Basin the beds dip $2^{\circ}-8^{\circ} \mathrm{N}$. Along the north side of the Uinta Basin the Green River formation does not crop out but is covered by an overlap of younger rocks, the Bridger and Uinta formations, which dip gently northward. The exact location of the axis of the Uinta Basin is not known, but it is probably 12 or 15 miles north of the Duchesne River. North of that axis the roeks of the Uinta formation dip gently southward.

\section{MINOR FEATURES}

Near Deep Channel Creek, in the southern part of Moffat County, Colo., there are two small and apparently short faults, the only ones observed in the Green River formation in Colorado south of the Uinta Mountains. Many small and very low folds are superimposed on the major structural features. Most of these are mere undulations that can be defined only by instrumental survey. In the Uinta Basin in Utah there are several small anticlines in the vicinity of the Strawberry River and Indian Creek, the axes of which roughly parallel the major axis of the basin. Locally these folds have dips as high as $18^{\circ} \mathrm{S}$. and $15^{\circ} \mathrm{N}$. They are cut by many small faults, most of which are nearly parallel to the axes of the folds. It is probable that more detailed mapping in the Uinta Basin will disclose other minor structural features like these.

A few miles west of Watson, Utah, there is a remarkable system of nearly parallel long, straight fractures which are approximately radial to the basin. Eldridge, ${ }^{15}$ after remarking about the scarcity and small displacement of the faults in the Uinta Basin, says of these fractures:

The basin is nevertheless the seat of a large number of most remarkable vertical cracks, now filled with the various asphaltites, from one-sixteenth of an inch to 18 feet across, and in length from a few hundred yards to 8 or 10 miles. Their walls are smooth and regular, they show but the slightest undulation, and between the strata on opposite sides not even the slightest displacement can be detected. The cracks have a direction varying between $N .35^{\circ}$ W. and $N .55^{\circ}$ W., and except for an occasional short, sharp transverse throw are peculiarly straight in trend. In some localities they appear to be approximately parallel with the strike of the strata and the trend of the main flexures in the ranges and their foothills; in others they cut the strata diagonally to the strike. On this account there is not everywhere suggested a connection in their genesis with the broader structural folds. Again, none of the cracks show the irregularities of fissures formed by the tearing asunder of strata along the axis of an anticline, nor are there the slickensides occasioned by the rubbing together of the walls in displacement. The termination of a crack, either in outcrop or vertically, may occur by the gradual approach of its two walls but, as will appear subsequently, may also take place from other causes.

Farther west, in Indian and Avintaquin Canyons and in the upper part of the Strawberry River Valley,

is Eldridge, G. H., The asphalt and bituminous-rock deposits of the United States: U. S. Gedl. Survey Twenty-second Ainn. Rept., pt. 1, p. .339, 1901. 
there are several similar but smaller fractures filled with elaterite. These trend about N. $25^{\circ} \mathrm{E}$. and are also radial to the basin.

The minor structural features very probably were incidental to the major downwarping and are therefore contemporaneous with it. The small faulted anticlines in the Uinta Basin are near the axis of the basin, the site of greatest shortening, and are apparently the result of compression. Straight vertical cracks radial to the basin and without differential movements of the walls; such as the gilsonite veins near Watson and Dragon, Utah, and the elaterite veins in the vicinity of Indian and Avintaquin Canyons, are apparently due to purely tensional strains. These tensional strains may have been produced by hills and ridges on the pre-Tertiary surface, which hindered downwarp of the Tertiary rocks.

\section{AGE OF FOLDING}

The Uinta formation, of upper Eocene age, comprising the youngest rocks of the basin, took part in the major deformation, which is therefore post-Eocene. It may perhaps have been later than early Miocene and coincident with a partial collapse of the east end of the Uinta Mountain arch, which faulted and in places strongly flexed beds of the Browns Park formation that are probably of late Oligocene or early Miocene age. ${ }^{18}$ However, there are at hand no evident means of correlating these two movements, and consequently there appears to be no way to date the movement more closely without much more information on the geologic and physiographic history of the Green River drainage system, especially in the Uinta Mountains.

\section{STRATIGRAPHY}

Although the purpose of this report is to describe the Green River formation of Colorado and Utah and in particular to interpret the physiographic, environmental, and climatic conditions that attended the deposition of its oil shale, the study would be incomplete if it did not also briefly describe and interpret the rocks that immediately underlie and overlie this formation. The rocks described here were formed in large structural basins by essentially continuous aggradation that lasted throughout the Eocene epoch and probably longer. The Green River formation represents a predominantly lacustrine phase of the basin fillings and rests upon the Wasatch formation, of fluviatile origin. It is overlain by the Bridger and Uinta formations, which are also dominantly fluviatile.

\section{IITHOLOGIC TERMS OSED}

Certain descriptive terms applied to sedimentary rocks lack precision, and through continued loose

${ }^{10}$ Sears, J. D., Relations of the Browns Park formation and the Bishop conglom. erate and their rôle in the origin of Green and Yampa Rivers: Geol. Soc. America Bull., vol. 35, pp. 286-298, 1924. usage a few of them have a variety of meanings, the extremes of which differ widely. Because of this uncertainty the writer proposes to define those lithologic terms used in this report that have more than a single common meaning.

Claystone and siltstone are both massive finegrained rocks defined by the size of the predominant grains. According to Atterberg ${ }^{17}$ clay-sized particles are 0.002 millimeter or less in diameter and silt-sized particles range from 0.002 to 0.02 millimeter. Grains larger than 0.02 millimeter fall into the several grades of sand and gravel. Wentworth's classification ${ }^{18}$ differs from Atterberg's scale by including larger grains in the silt class. Wentworth puts the division between clay and silt at 0.004 millimeter and the upper limit of silt at about 0.062 millimeter. Although the name "claystone" is not intended to imply any particular mineralogy, it is likely that most of the crystalline grains less than about 0.004 millimeter in diameter belong to the general group of so-called clay minerals. But these so-called clay minerals are not by any means restricted in size and may be of such dimensions as to be properly classified as silt or even as sand. The adjectives "clayey" and "silty" imply an appreciable content of either clay or silt-sized particles.

Mudstone is also a fine-grained massive rock, but it consists of an indefinite mixture of clay, silt, and sand-sized grains, and therefore the term is more general than "claystone" or "siltstone." Consequently the adjective "muddy" signifies a rock with an admixture of enough particles smaller than fine sand to change its general aspect.

American usage of the term "marl" is very diverse. Dana ${ }^{19}$ defined marl as

a clay containing a large proportion of lime, sometimes 40 to 50 per cent. If it consists largely of shells or fragments of shells then it is termed a shell marl. Marl is used as a fertilizer, and beds of sand and clay that can be so used are often in a popular way called marl.

Perhaps this indefinite popular use has led to vague usage by American students of geology. Merrill ${ }^{20}$ says that

the name shell marl or merely marl is given to an illy defined, often arenaceous soft earthy rock consisting essentially of shell material in a more or less fragmental condition and usually intermixed with more or less clayey matter or siliceous sand and silt.

Pirsson ${ }^{21}$ held the apparently unique view that "when a soil contains a considerable quantity of calcium carbonate it is termed a marl." Despite this variety, most American textbooks agree that in com-

17 Atterberg, A., Die rationelle Klassifikation der Sande und Kiese: Chem. Zeitung, vol. 29, No. 15, pp. 195-198, 1905.

${ }_{18}$ Wentworth, C. K., A scale of grade and class terms for clastic sediments: Jour. Geology, vol. 30, pp. 377-392, 1822.

${ }^{19}$ Dana, J. D., Manual of geology, 4th ed., p. 79, 1805.

20 Merrill, G. P., A treatise on rocks, rock weathering, and soils, new ed., p. 128, 1906.

"Pirsson, L. V., and Schuchert, Charles, A tertbook of geology, pt. 1, 2d ed., p. 29,1920 , 
position a marl is a mixture of clay or mud and a rather large percentage of calcium carbonate. Opinions on the induration and structure of marl are less definite, for some writers regard marl as a wholly unconsolidated deposit, whereas others regard it as a soft earthy rock, and still others use "marl" more or less synonymously with "greensand."

European usage of the term "marl," though not entirely uniform, is less diverse than American usage. De Lapparent ${ }^{22}$ defines marl as a rock in which the clayey constituents are abundant and equal or exceed the quantity of carbonates. The rock may be dolomitic and may be rather hard. Rosenbusch ${ }^{23}$ does not restrict the proportions of the constituents. He says:

Marl and dolómitic marl are intimate mixtures of crystalline calcite, occrsionally of dolomite, with clayey substances whose character is not well known. $* * *$ In such mechanical mixtures the individual constituents vary between the widest limits, and, indeed, they show transition forms between limestone and dolomite on the one hand and clays and sandstones on the other.

The harder varieties of marl he calls marlstone.

Many beds in the Green River formation not only have the chemical composition and mineralogy of marl, but their texture is intermediate between that of mudstone and limestone, so that if they are not designated by some single term they must be described by cumbersome groups of terms like "very muddy limestone" or "very limy mudstone." "Marlstone". appeals to the writer as a particularly appropriate term to apply to these rocks. They are all fine grained and rather dense, and they contain various proportions of organic matter. Their hardness ranges from that of hard chalk to that of relatively pure, fine and close grained limestone. Their colors range from nearly white to chocolate-brown.

Claystone, siltstone, mudstone, and marlstone, as the terms are here used, are all massive rocks. They may be homogeneous in color and texture, or they may show very pronounced bedding laminae, provided, however, there is no distinct tendency to part along these closely spaced bedding planes.

"Shale" is regarded as a structural term coordinate with "slate" as advocated by Lewis, ${ }^{24}$ who says:

It implies no particular composition except so far as certain materials of fine texture lend themselves to the development of the characteristic structure. This structure, or fissility, may be defined as the capacity of clayey strata for splitting into somewhat uneven flakes, thin chips, and wedgelike fragments approximately parallel to the bedding. $* * *$ Fissility is typically developed in most of the clay rocks of finer texture and in various unsorted mixtures, such as silty clay, sandy clay, and mud, and is commonly most conspicuous on weathered surfaces.

\footnotetext{
22 De Lapparent, A., Legons de pétrographie, pp. 376-378, 1923.

${ }_{23}$ Rosenbuseh, H., Elemente der Gesteinslehre, 4th ed., revised by A. Osann, pp. $561,563,1923$.

${ }^{24}$ Lewis, J. V., Fissility of shale and its relations to petroleum: Geol. Soc. America Buil., vol. 35 , p. $568,1924$.
}

Although the term "shale" defines the size of the constituent particles of the rock only within a general range, it must imply that a large proportion of the particles are thin and flakelike. Otherwise the rock could not be fissile. These flaky particles may have been deposited in that form or they may have grown within the sediment during its compaction and solidification. The characteristic particle shape, therefore, may be original or secondary. Consequently "shaly" is used here to modify such rock names as "marlstone" and "mudstone" to indicate that they have either a slight or an apparent fissility but yet insufficient to be regarded as shale.

"Paper shale" is the term applied to finely laminated claystones, siltstones, mudstones, and marlstones that show a pronounced tendency to part along the closely spaced bedding planes. This tendency is probably. due in part to an original structure, but it seems that it might be more or less accentuated by the secondary process of compaction. For example, if for any reason there was a concentration of minute flakes of a micaceous clay mineral, or any other flat particles, at the top of each lamina, then compaction of the sediment would induce there a parallel orientation of the flat particles sooner than in other parts of the lamina. In so far as this parallelism is secondarily induced it is virtually fissility. It might possibly bo regarded as a special type of fissility, because it coincides exactly with the bedding planes. Actually paper shale consists of very thin laminae of nonfissile rock separated from one another by excessively thin laminae that are fissile. The origin of these laminae that give rise to the paper shale in the Green River formation is discussed more fully in another report. ${ }^{25}$

In accordance with a recent decision ${ }^{26}$ of the Secretary of the Interior, any shale that will yield oil when distilled will be regarded under the general mining laws as oil shale. Although this definition is suitable for that purpose, it is not precise enough to designate what most geologists regard as oil shale, for it would also include most sorts of carbonaceous shale and also shale saturated with petroleum that can be almost wholly extracted with ordinary petroleum solvents. The writer therefore proposes the following definition:

Oil shale is a fine-grained sedimentary rock containing organic matter which was derived chiefly from aquatic organisms or waxy spores and pollen grains, which is only slightly soluble in ordinary petroleum solvents, and of which a large proportion is distillable into artificial petroleum. Despite the name most rich beds' of oil shale in the Green River.formation could not be regarded strictly as shale. Instead they are more or less

${ }^{25}$ Bradley, W. H!, The varves and climate of the Green River epoch: V. S. Geol. Survey Prof. Paper 158, pp. 100-103, 1929.

28 J. D. Freeman vs. G. I. Summers; Standard Shale Produets Co. vs. G. I. Summers, Sept. 30, 1927: Decisions of the Department of the Interior relating to public lands, vol, 52 (in preparation). 
magnesian marlstones rich in organic matter. Nevertheless a few are shaly. On the other hand, many low-grade oil-shale beds are paper shale. By low grade is meant any oil shale that will yield less than 10 gallons of oil to the ton. This division between low and high grade oil shale is arbitrary and is adopted merely as a convenience in exposition. It is the same that the writer has used in his earlier reports. The character and composition of the different types of oil shale in the Green River formation are discussed fully on pages 22$32,36,37$.

\section{WASATCH FORMATION}

The Wasatch formation, of lower Eocene age rests upon rocks of earliest Tertiary age or older, in some places with distinct unconformity and in others with apparently transitional contact. Between theWasatch and the overlying Green River formation there is a transitional zone of variable thickness.

According to Osborn, ${ }^{27}$ the Wasatch formation of the Uinta Basin is characterized by fossils from the upper three of the life zones assigned by him to the lower Eocene epoch-the Lambdotherium-Eotitanops-Coryphodon zone, the Heptadon-Coryphodon-Eohippus zone, and the Systemodon-Coryphodon-Eohippus zone. The Wasatch formation of the Bridger Basin of Wyoming and Utah is lithologically almost identical with that of the Uinta and Piceance Creek Basins and separated from it by only about $13 \frac{1}{2}$ miles across the Axial Basin anticline in central Moffat County, Colo. In the vicinity of Evanston, Wyo., it is characterized by fossils from the Heptadon-Coryphodon-Eohippus zone. As indicated by the fossils of these life zones the Wasatch formation of the Uinta and Piceance Creek Basins is equivalent to that in the Bridger Basin. It is also correlative with the "Sand Coulee" and "Grey Bull" horizons of the Wasatch formation in the Big Horn Basin. $^{28}$

The Wasatch formation consists chiefly of variegated mudstone with a subordinate amount of friable gray or brown sandstone in irregular and discontinuous lenses. Locally, however, regularly bedded sandstone is abundant. The mudstone displays a great variety of colors and shades, including drab, gray, green, yellow, buff, brick-red, pink, mauve, maroon, lavender, bluish gray, brown, and black. Drab and pink or red, however, are the prevailing colors. Such colors occur either in irregular zones or thin and rather persistent beds presenting a banded aspect. The sandstone is generally medium to coarse grained, poorly sorted, soft, and light gray or buff, but most of it weathers dark brown. Many of the lenses are massive, but some are cross-bedded or ripple bedded. The more

\footnotetext{
2: Osborn, H. F., The titanotheres of ancient Wyoming, Dakota, and Nebraska: U. S. Geol. Survey Mon. 55, p. 59, 1929.

${ }^{28}$ Granger, Walter, On the names of lower Eocene faunal horizons of Wyoming and New Mexico: Am. Mus. Nat. History Bull., vol. 33, pp. 203-205, 1914.
}

regularly bedded sandstone is prevailingly buff, though locally it ranges from dark gray to almost white. Cross-bedding and ripple bedding are about as abundant in the regular beds as in the lenses. Conglomerate is locally plentiful near the base, and at a fow places it occurs in thin zones throughout the formation. In the Wasatch Plateau limestone makes up nearly one-third of the Wasatch formation, but in most of the area considered in this report limestone is rare.

The upper part of the Wasatch formation is exposed nearly everywhere adjacent to the outcrop of the Green River formation in Colorado and Utah except along the north side of the Uinta Basin, where it is covered by a wide northward overlap of the Uinta formation. The Wasatch formation makes conspicuous and at places brightly colored badland cliffs or scars on the steep slopes of plateaus and buttes, particularly where it is sharply upturned, as along the Grand Hogback, just east of the Piceance Creek Basin. In the broader valley bottoms it weathers to low, well-rounded hills or isolated knobs that show badland scars in only a few places. Along the eastern margin of the Piceance Creek Basin north of Rio Blanco the Wasatch formation contains very little sandstone but many thin zones of brightly colored chert and igneous-rock pebbles in a sandy mudstone matrix. Petrified wood, much of it waterworn, is also abundant there. Southward from Rio Blanco lenses of channel sandstone become more plentiful. In many of these the sandstone is coarse grained or even gravelly and poorly sorted. Some are ferruginous.

The thickness of the formation in northwestern Colorado is fairly uniform. A complete section measured at Price Creek post office, Moffat County, in 1924 , is about 3,500 feet thick. Gale ${ }^{29}$ says that the Wasatch at Rio Blanco is about 3,400 feet thick. Another complete section about 10 miles northwest of Rifle, Colo., measured by the writer in 1925, shows about 3,900 feet. According to Lee ${ }^{30}$ the lower part of the Wasatch formation southeast of Grand Mesa is very conglomeratic but becomes less so toward the west, passing from conglomerate to sandstone and variegated mudstone.

The Wasatch formation thins decidedly toward the west side of the Piceance Creek Basin. C. E. Erdmann, ${ }^{31}$ of the Geological Survey, measured two complete sections of the Wasatch between Debeque and the Fruita-Rangely Road. One along Hunter Canyon in secs. 21 and 16, T. 8 S., R. 100 W., Mesa County, Colo., is about 1,000 feet thick and includes at its base a few hundred feet of sandstone with some beds of conglomerate. The other section, about 16 miles to the northwest, in the canyon of East Salt Creek,

${ }^{29} \mathrm{Gale}$, H. S., Coal fields of northwesterni Colorado, and northeastern Utah: U. S. Geol. Survey Bull. 415, p. $82,1910$.

${ }^{30}$ Lee, W. T., Coal fields of Grand Mesa and the West Elk Mountains, Colo. U. S. Geol. Survey Bull. 510, p. 51, 1812.

s1 Personal communication. 
in sec. 15 , T. 7 S., R. 102 W., Garfield County, Colo., is about 800 feet thick and consists chiefly of drab clay. Northwestward the formation apparently thins still more. Reeside ${ }^{32}$ estimated the total thickness to be 400 feet near the divide between Douglas Creek and East Salt Creek, approximately on the arch that separates the Uinta Basin from the Piceance Creek Basin. The formation there consists mostly of drab mudstone with only a few thin bands of red.

In the Uinta Basin the Wasatch thickens again. Spieker and Reeside ${ }^{33}$ measured a section of it above the Book Cliffs a few miles west of the Green River and give a thickness exceeding 3,600 feet. As there are no measurements of the Wasatch formation between this locality and the Douglas Creek anticline, it is impossible to say how rapidly the formation thickens westward into the Uinta Basin. Spieker and Reeside also give a complete section of the Wasatch formation on Willow Creek, north of Castlegate, Utah, which is about 3,200 feet thick.

In the Wasatch Plateau the same authors ${ }^{34}$ found a lacustrine phase about 1,000 feet thick near the middle of the Wasatch formation. It consists almost exclusively of dense gray limestone.

\section{GREEN RIVER FORMATION}

The Green River formation of middle Eocene age, was named by Hayden ${ }^{35}$ because of its excellent exposures in Wyoming along the Green River. The type locality of the formation is at the town of Green River, Wyo. Sections measured by Winchester ${ }^{36}$ near that town, in Tps. 17 and 19 N., R. 106 W., show a thickness of about 1,350 feet. These sections include the Tower sandstone lentil, 125 to 245 feet thick, at the top. Most of the formation at the type locality consists of finely laminated marlstone, some of which is oil shale. There is a basal unit of limy or sandy shale and marlstone that weathers buff or gray-buff. This is the Tipton shale member. Overlying the Tipton is the Laney shale member, which makes up most of the formation there. The Laney shale member can be divided into two nearly equal units, of which the lower contains more marlstone and sandstone than the upper and weathers a rather somber gray. The upper unit is nearly all finely laminated marlstone, shale, and oil shale and weathers stark white. A thin but very persistent buff zone separates the two units. The Morrow Creek member, nearly all crudely bedded sandy and limy shale or shaly marlstone that weathers yellowish brown, forms the upper part of the formation

3 Reeside, J. B., jr., personal communication.

3 Spieker, E. M., and Reeside, J. B., Ir., Cretaceous and Tertiary formations of the Wasatch Plateau, Utah: Geol. Soc. America Bull., vol. 36, p. 440, 1925.

34 Idem, pp. 440, 448-449.

as Hayden, F. V., U. S. Geol. and Geog. Survey Terr. Third Ann. Rept., p. 90, 1869.

30 Winchester, D. E., Oil shale of the Rocky Mountain region: U. S. Geol. Survey Bull. 729, pp. 124-126, 1923. and at the type locality of the Green River formation includes the Tower sandstone lentil.

\section{AGE}

Osborn ${ }^{37}$ assigns the Green River formation to the upper part of the lower Eocene, making it equivalent to the lower Ypresian of the European section. Berry ${ }^{38}$ believes that the flora indicates a somewhat younger age and compares the Green River to the Claiborne and possibly also the lower part of the Jackson of the Gulf coast region. He at first regarded it as equivalent to the European Bartonian. More recently Berry ${ }^{39}$ has expressed the opinion that the Green River formation is to be correlated with the Auversian stage of the European section, thus making it a part of the middle Eocene of this country.

\section{LITHOLOGY}

The lithologic description of the Green River formation is divided into two parts, covering the rocks east and west of Bitter Creek, Utah. This creek was chosen chiefly because it is a convenient line about midway between the detailed section near Watson, Utah, and that near the Duchesne-Uintah county line. Across the area between these localities the lithologic units of the -Watson section, except the principal oilshale zone, have not been traced. Partly also, however, the division was placed here because the Green River formation in the vicinity of Watson is much more like that in Colorado than that west of Bitter Creek.

\section{ROCKS EAST OF BITTER CREEK, UTAB}

For convenience of description and interpretation the rocks of the Green River formation in the eastern area have been divided into four members-the Douglas Creek member (at the base), the Garden Gulch member, the Parachute Creek member, and the Evacuation Creek member (at the top). (See pls. 7 and 8.) The stratigraphic relations of these members in different parts of the Piceance Creek Basin and in the extreme eastern part of the Uinta Basin are shown diagrammatically in Plate 3 . These members persist throughout most of this area, though they vary in thickness from place to place and lose their identity where they merge into a shore facies. Each member represents more or less widely divergent conditions of deposition from those below and above.

\section{DOUGLAS CREEK MEMBIFR}

The rocks making up the high ridge which separates the drainage basin of West Douglas Creek from that of Trail and East Salt Creeks are typical of the basal

${ }^{37}$ Osborn, H., F., op. cit., p. 66.

${ }_{38}$ Berry, E. W., The middle and upper Eocene floras of southeastern North America: U. S. Geol. Survey Prof. Paper 92, p. 35, 1924.

${ }^{39}$ Berry, E. W., Flora and ecology of so-called Bridger beds of Wind Rivet Basin, Wyo.: Pan-Am. Geologist, vol. 44, p. 360, 1925. 
part of the Green River formation east of Bitter Creek. Because this group of beds, which constitutes a distinctive and mappable unit, is so thick and so well exposed at the head of Douglas Creek, especially in the east half of T. 5 S., R. 102 W., Garfield County, Colo., the writer proposes to call it the Douglas Creek member of the Green River formation. (See pl. 8.)

The beds of this member are characteristically buff or yellowish brown and in most places contrast markedly with the underlying drab or variegated mudstone of the Wasatch formation and the overlying gray or bluish-gray marlstone and oil shale. The member ranges in thickness from about 200 feet on Piceance Creek to nearly 800 feet near the head of Trail Creek. It differs from the bulk of the formation in having relatively large proportions of sandstone, limestone, algae reefs, and oolite. Moreover, the marlstone and shale beds are notably different from those in other parts of the formation, as many of them are silty and interbedded with very fine grained sandstone. The amount of oil shale is negligible.

The bedding is regular in general, but within the beds and on the bedding planes there are many small irregularities. Ripple marks of both oscillation and current origin ${ }^{40}$ are plentiful, but oscillation ripples predominate, and most of the current ripples are nearly symmetrical. Sandstone and siltstone beds are locally cross-bedded through a small vertical range. In a few places ostracode-bearing limestone and oolite beds also are cross-bedded. Other small irregularities such as minute faults, variations in thickness of individual laminae, and contortion by differential compaction of thin layers also occur in the sandy shale and mudstone. These are accompanied by undulating bedding planes. Mud cracks, curls, and edgewise conglomerate occur but are not nearly so abundant as higher up in the formation. Mudstone lumps of various shapes are more plentiful in the Douglas Creek member than elsewhere in the Green River formation. In a few places well-formed oscillation ripples were covered with a thin film of yellow mud, which in turn was distinctly mud cracked.

Ostracode-bearing shale and marlstone are characteristic rocks of the Douglas Creek member and in many places are associated with oolite. Locally ostracodes make up considerable masses of rock. Gastropods and pelecypods are also locally plentiful but are not so characteristic of the basal member in this area as west of Bitter Creek or in Wyoming. Vertebrae, fin rays, and other fragments of small fish skeletons are surprisingly abundant in the southwestern part of the Piceance Creek Basin. Scattered pieces of turtle carapaces and crocodiles occur near the base of the Douglas Creek member at the north

\footnotetext{
io Bucher, W. H., On ripples and related sedimentary surface forms and their paleogeographic interpretation: Am. Jour. Sci., 4th ser., pp. 149-210, 241-269, 1919.
}

end of this basin. Fragmentary plant remains, mostly stems and ribs of leaves, occur rather sparingly but uniformly distributed through the member.

GARDEN GULCH MEMBEER

In most places east of Bitter Creek the transition upward from the Douglas Creek member is abrupt and marked by a change from yellowish brown or buff to light gray, as well as by a distinct change in lithology. The overlying member will be designated herein the Garden Gulch member because it is so thick and so fully exposed in the bluffs near the mouth of Garden Gulch, a short gulch tributary to Parachute Creek in secs. 7 and 8, T. 6 S., R. 96 W., Garfield County, Colo. (See pl. 7.) The rocks of this member weather either to a smooth slope or to one interrupted only by low, rounded, and discontinuous benches. Its topographic expression is thus noticeably different from that of either the Douglas Creek member, which makes steeper slopes broken by low but precipitous ledges, or the overlying oil shale bearing rocks, which generally make steep and rather high but broken cliffs. (Stee pl. 4, A.) The thickness of this member ranges from a little more than 200 feet in Hells Hole Canyon, near Watson, Utah, to about 700 feet in the Parachute Creek Canyon, north of Grand Valley, Garfield County, Colo.

Paper shale with discrete laminae less than 1 millimeter in thickness, many to be measured in a few hundredths of a millimeter, is the characteristic feature of this second member of the Green River formation. Shale of this type constitutes 20 to about 40 per cent of the member, and is one of the most remarkable rocks of the formation. It occurs in unbroken units 20 to 70 feet thick, aggregating thousands of monotonously. uniform, paper-thin layers, each sharply separated from the next. Many of these paper-thin layers are lowgrade oil shale and are surprisingly flexible. Their flexibility increases with their content of organic matter. Some of the paper shale will yield more than 15 gallons of oil to the ton upon distillation. Such shale is dark chocolate-brown on the fresh surface but weathers gray. The leaner paper shale is buff or graybuff and weathers lighter gray or buff. Outcrops of the paper shale resemble piles of deckle-edge paper. (See pl. 4, B.)

Units of paper shale are intercalated with somewhat thicker units of flaky shale, which is also thinly but much less distinctly laminated. The greater part of the Garden Gulch member consists of flaky shale and more thickly laminated marlstone, some of which is shaly. Most of the marlstone is light gray or buff and weathers yellowish. Other limy deposits, however, such as oolite beds and algae reefs, are few or absent. Locally there are a few beds, several inches to a foot thick, of pale greenish-gray mudstone that contains an abundance of marcasite lenticules and concretions. 


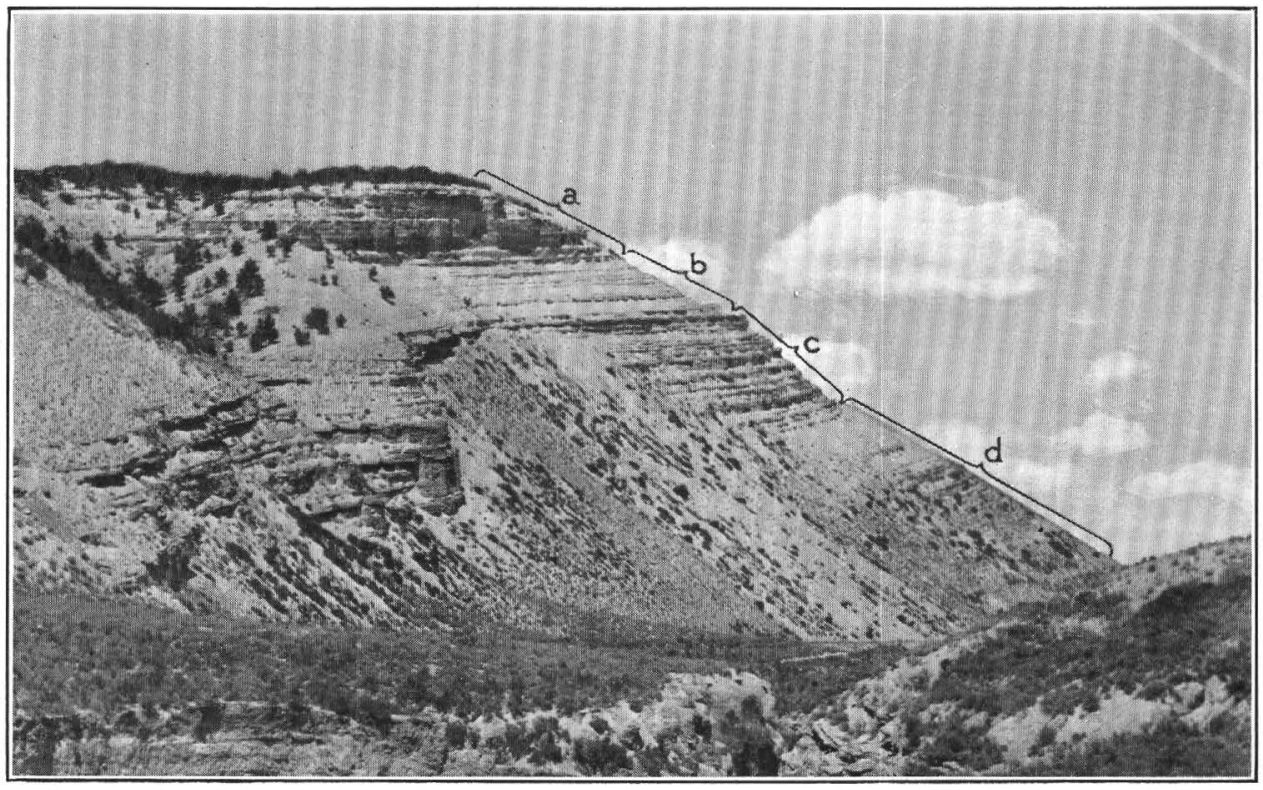

A. VIEW NORTH DOWN PICEANCE CREEK IN T. 1 N., R. 97 W., RIO BLANCO COUNTY, COLO. Above, three units of the Parachute Creek member of the Green River formation ( $a$, the lower part of the upper oilshale group; $b$, the transitional beds; $c$, the lower oil-shale group); below (d), the Garden Gulch member.

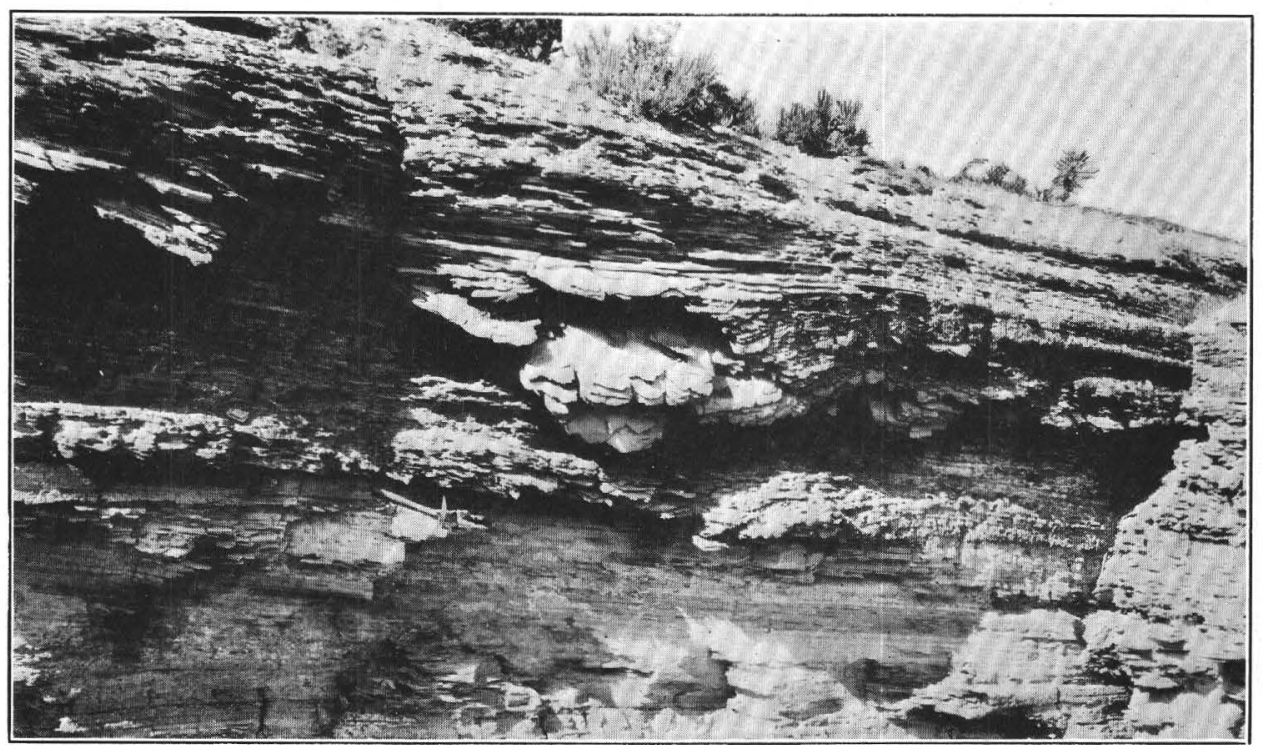

B. OUTCROP OF PAPER SHALE, SHOWING ITS FLEXIBILITY

Photograph by D. E. Winchester. 


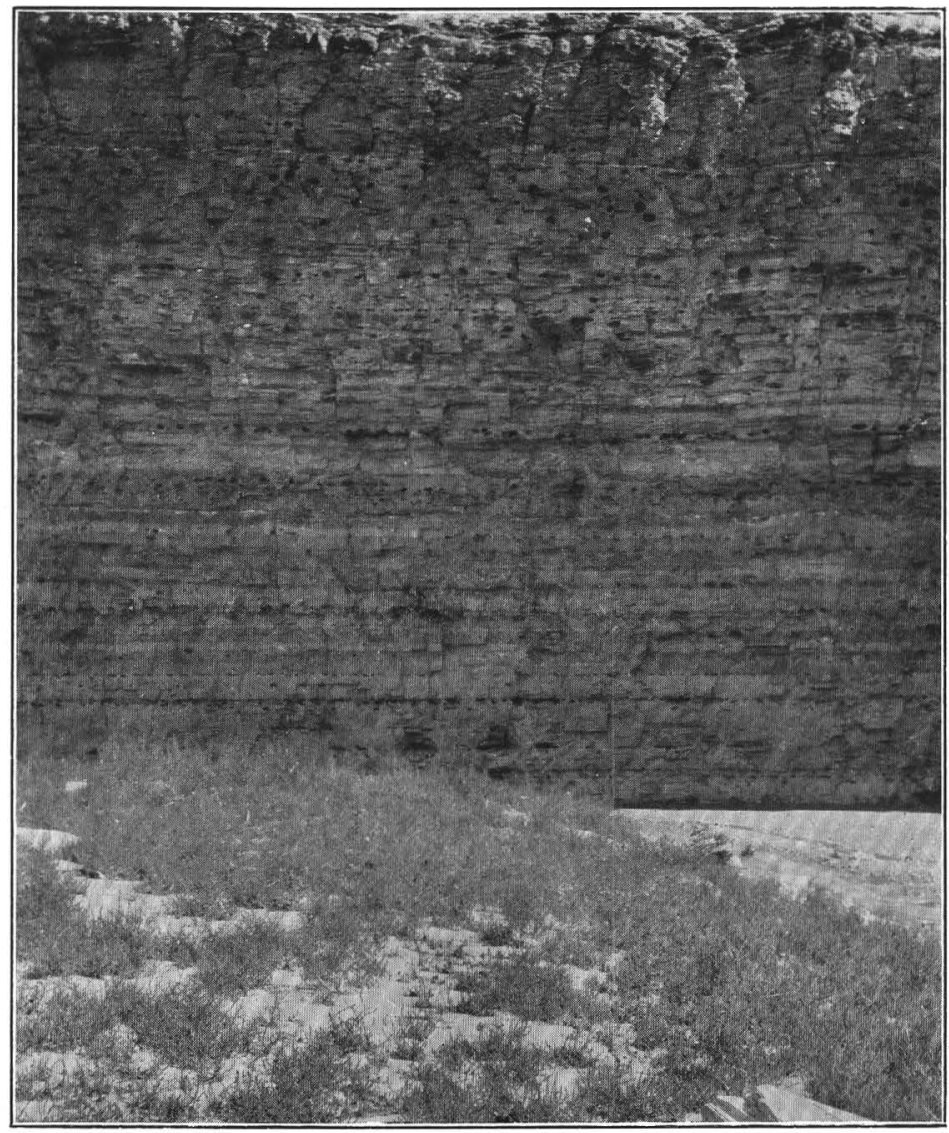

A. UPPER PART OF EVACUATION CREEK MEMBER IN EAST WALL OF EVACUATION CREEK CANYON IN SEC. 8, T. 10 S., R. 25 E. SALT LAKE MERIDIAN, UINTA COUNTY, UTAH

Shows numerous ellipsoidal cavities formed by the growth of bladed aggregates of an unknown salt while the beds were still plastic.

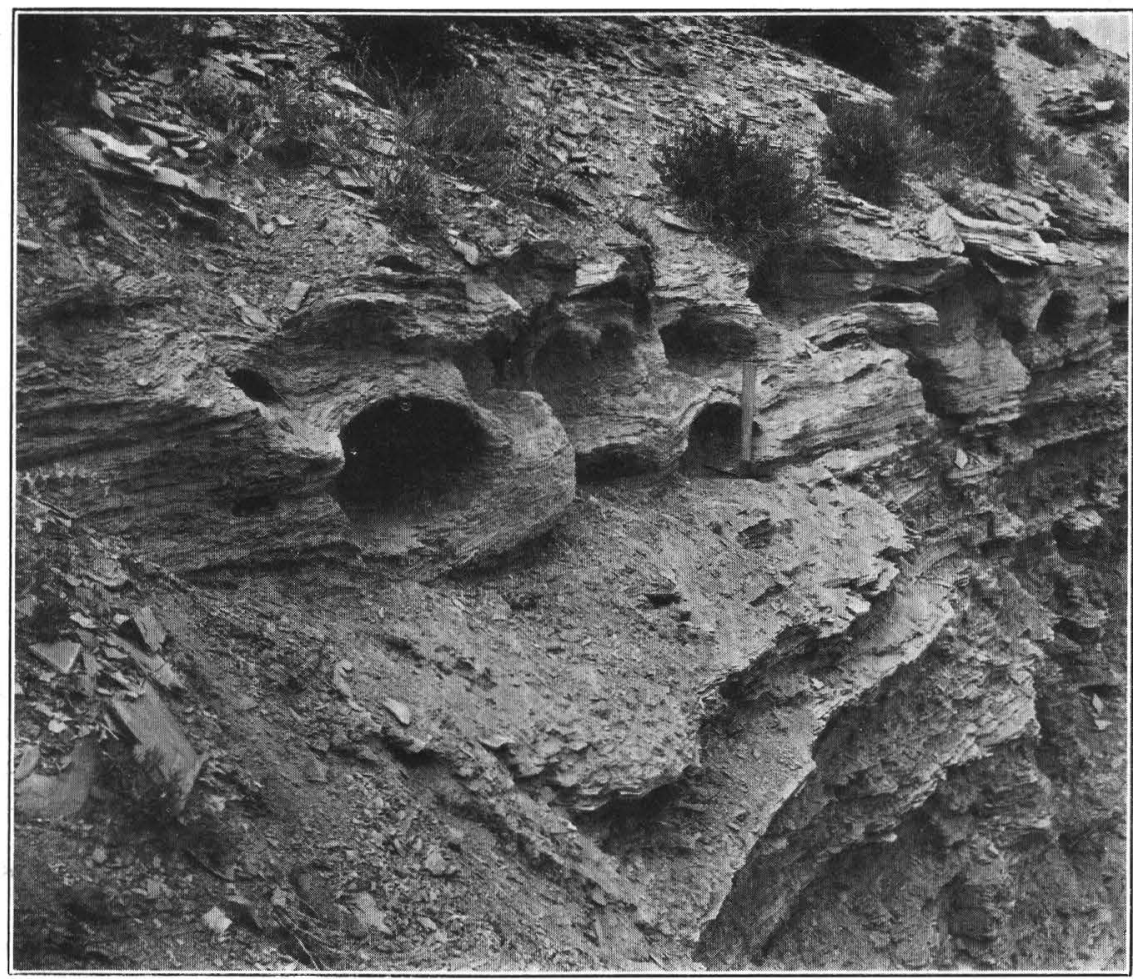

B. CLOSE VIEW OF CAVITIES FORMED IN A RICH OLL-SHALE BED BY THE GROWTH OF LARGE RADIAL AGGREGATES OF AN UNKNOWN SALT

Note the distortion of the laminae above and below the cavities. Photograph taken on the west side of Piceance Creek, Colo., near its mouth. 


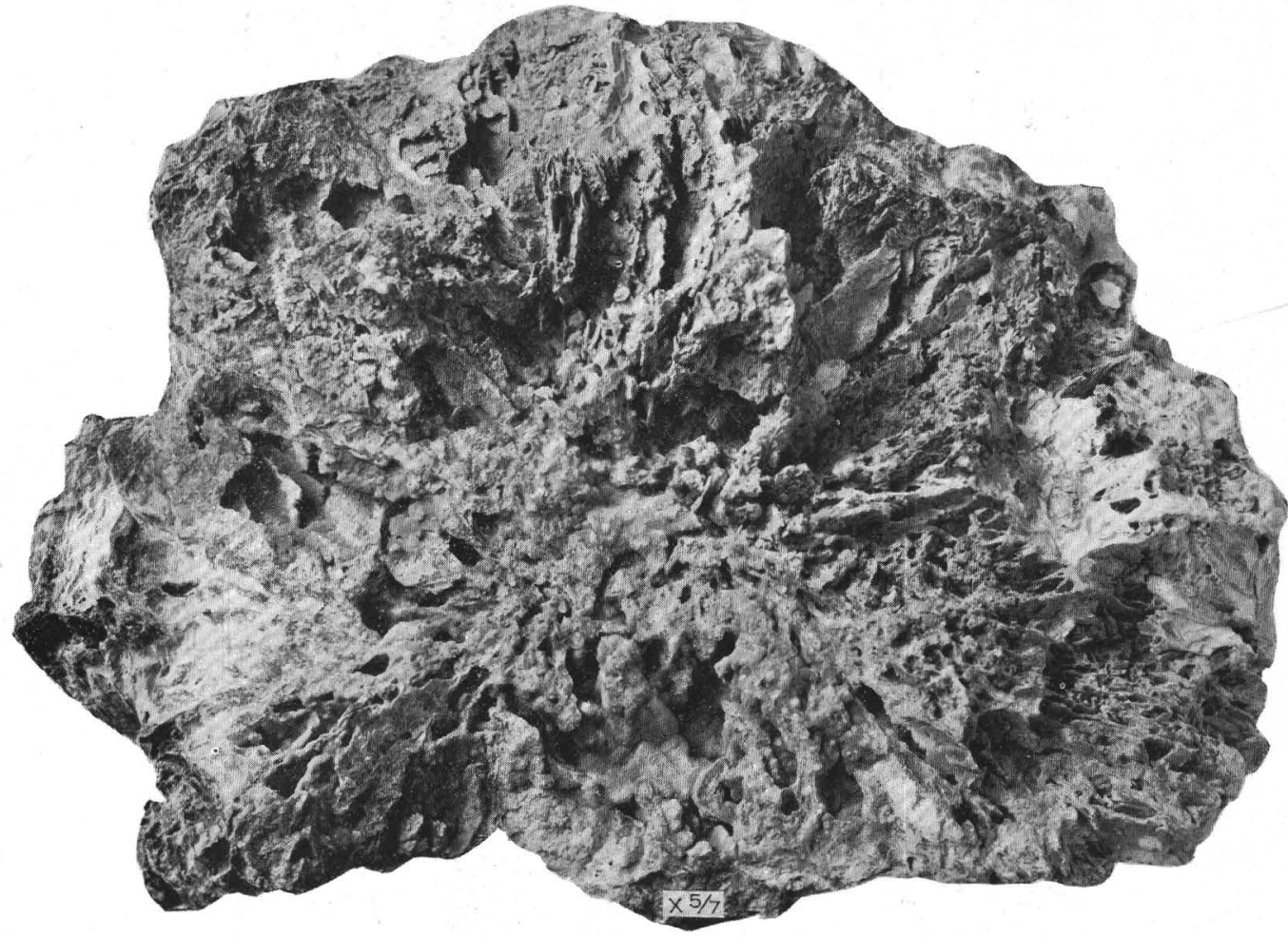

A. CALCITE MOLD OF RADIAL AGGREGATE OF SALT CRYSTALS FOUND IN SOME OF THE ELLIPSOIDAL CAVITIES SHOWN IN PLATE $5, B$

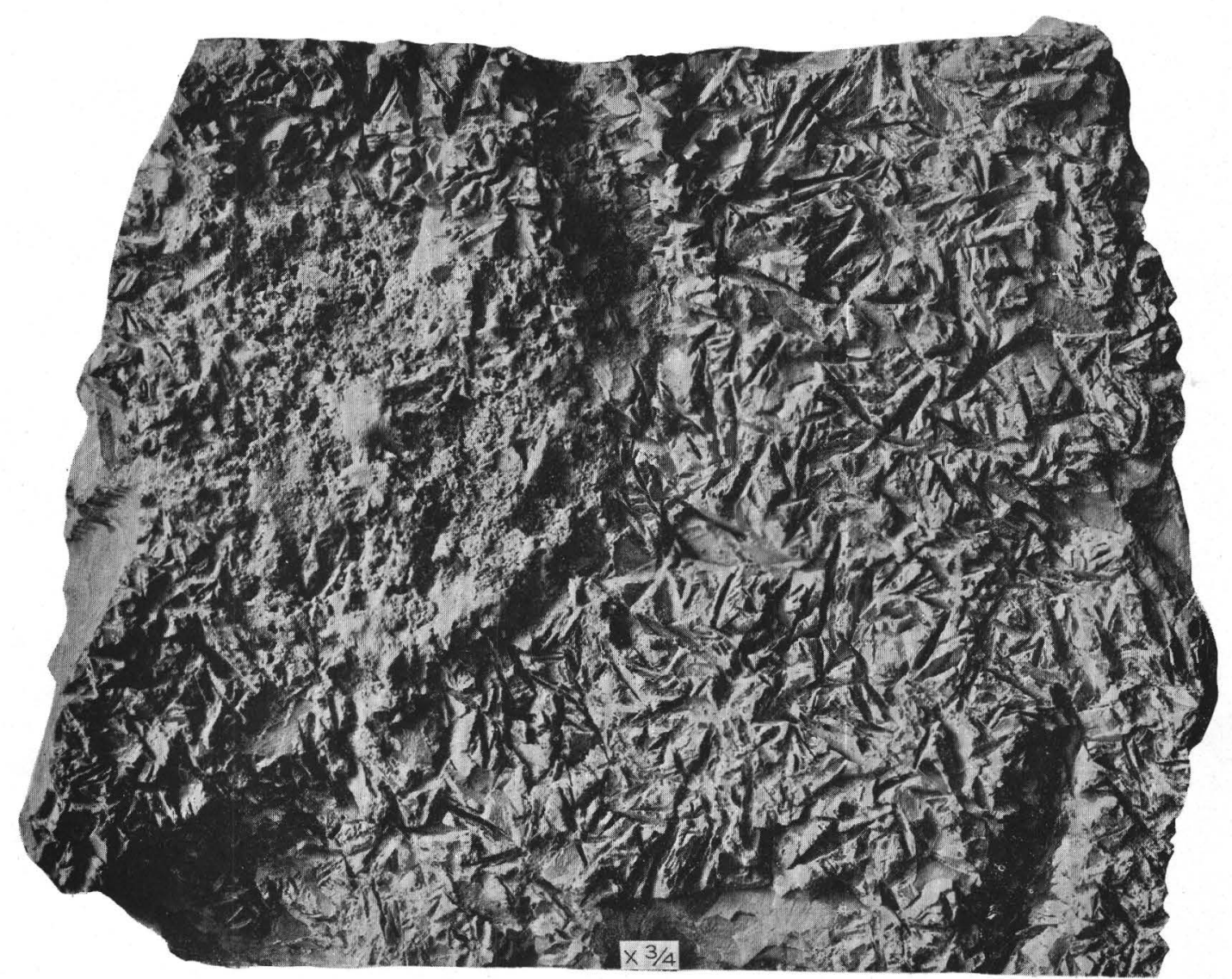

B. SALT CRYSTAL CAVITIES IN A BED OF MARLSTONE SUGGESTING INTERLOCKING PLATES OF ANHYDRITE 

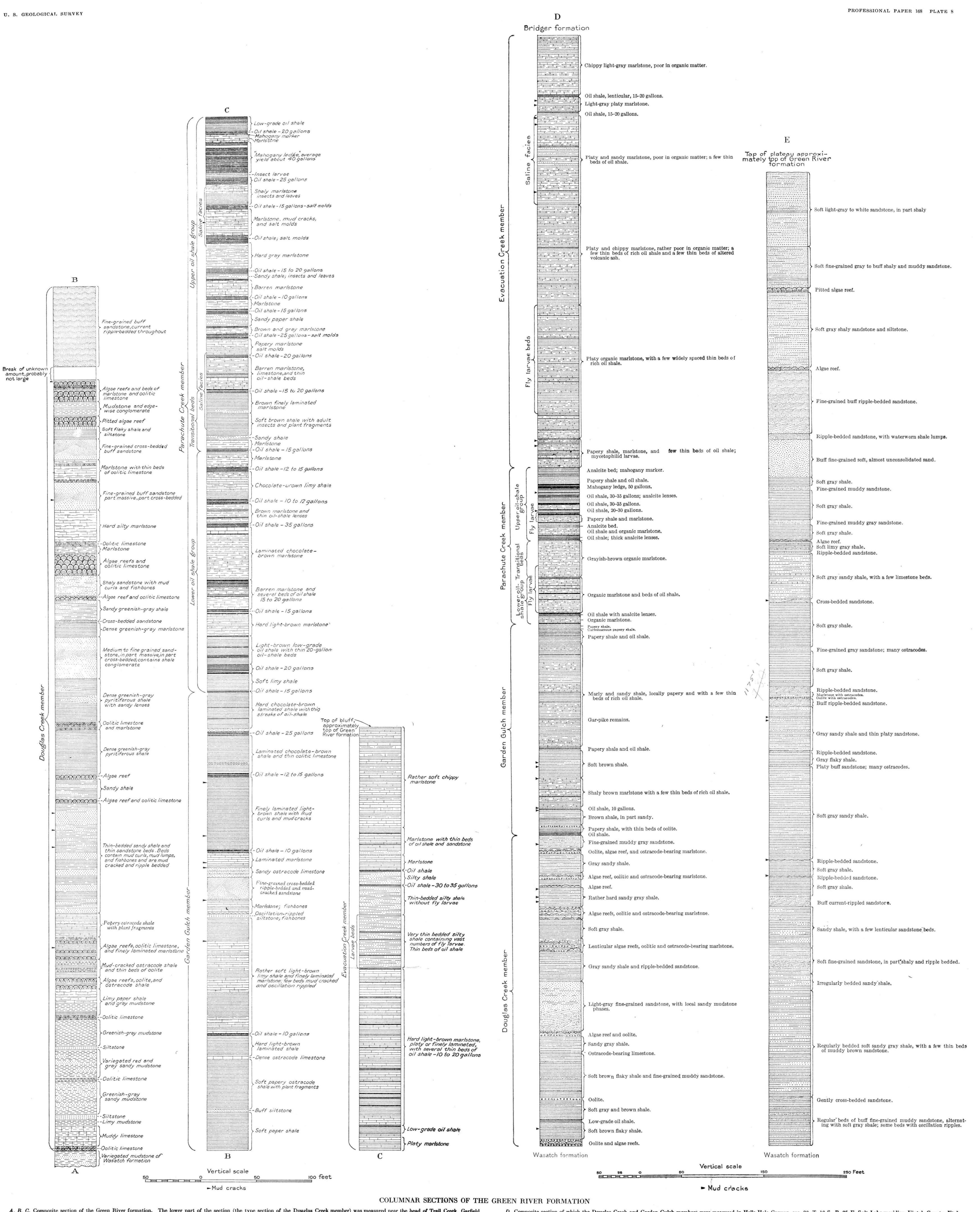

COLUMNAR SECTIONS OF THE GREEN RIVER FORMATION 
The Garden Gulch member contains only a few beds of fine-grained sandstone and siltstone, which in most places are thin bedded and platy. Nearly all these beds are gray on the fresh surface but weather dark brown. Some bear oscillation ripples, and a few show current-ripple bedding and cross-bedding.

Interbedded with the low-grade oil shale and nearly barren flaky and platy shale are a few thin elongate lenses of rich, massive oil shale, some of which are noticeably pyritiferous. Most of these lenses are less than 1 inch hick and 10 to 100 feet or more in length. In the northern part of the Piceance Creek Basin the Garden Gulch member includes several massive beds of oil shale 1 to 6 feet thick that may yield 15 gallons or more of oil to the ton.

Mud eracks are more abundant in this member than in any other part of the formation east of Bitter Creek. In the vicinity of Parachute and Cathedral Creeks, Colo., there are hundreds of closely spaced layers that are mud cracked. Mud cracks are less numerous in the section studied along the White River in Utah. On Piceance Creek, Colo., the Garden Gulch member was not examined for them. Near the head of Cathedral Creek mud cracks were noted in the troughs of large, sharp-crested oscillation ripples. In the more limy shale and sandy marlstone beds there are many mud curls but few edgewise conglomerates. Some of the oil-shale beds show mosaic brecciation. The term "mosaic breccia" is defined on page 28 , and in that part of the report the structure and significance of the shale breccias are discussed.

Ostracodes occur only sparingly in this member in thin limestone or lean paper-shale beds. Garpike scales are not numerous, and only a few skeletons of small fish were found. A few plant remains, mostly stem impressions and leaf fragments, were found in the sandstone and siltstone.

\section{PARACEUTE CREBK MEMBER}

The member next above the Garden Gulch member is distinguished from other parts of the formation by its content of oil-shale beds. It contains all the lárge groups of rich beds, most of the jndividual rich beds, and a very large proportion of the low-grade oil shale. As the oil-shale facies of the Green River formation reaches its maximum thickness and probably also its maximum richness in the vicinity of Parachute Creek, Colo., it seems particularly appropriate to name this unit the Parachute Creek member. This member ranges in thickness from about 175 feet in the vicinity of Watson, Utah, to a little more than 1,000 feet in the vicinity of Parachute Creek. It is predominantly a cliff-forming unit, and its top is marked by a soft limy sandstone which is conspicuous because of its bright ocherous color. This sandstone makes the top of the highest cliffs in the canyon of Parachute Creek and its tributaries. For convenience of description and discussion the oil-shale beds of the Parachute Creek member have been grouped into three units, designated here the lower oil-shale group, the transitional beds, and the upper oil-shale group. (See pl 7 )

Lower oil-shale group.-The lower oil-shale group is not a very clearly defined lithologic unit, but, as its rocks indicate different conditions of deposition from those which produced the beds above and below, it is a useful unit in discussing the origin of the formation and its geologic history. It is also a unit of economic interest, as it contains a considerable quantity of oil shale. The group is determined by its greater content of oil-shale beds with an estimated potential yield of more than 10 gallons of oil to the ton than occurs in either the member just below or the beds just above. East of Bitter Creek the thickness of the lower oil-shale group ranges from about 45 feet to nearly 200 feet, and the proportion of oil shale ranges from about 9 per cent to a little more than 30 per $\checkmark$ cent. The percentage of oil shale in this group is roughly proportional to the total thickness of the group.

In most of the Piceance Creek Basin the lower oilshale group makes a steep cliff that is prevailingly light buff or yellowish gray. The oil-shale beds, which weather bluish gray, give the cliff a faint color banding. Along the White River, both in Utah and in Colorado, the group is somewhat softer, perhaps because of less lime in the shale, and makes stepped cliffs or ledges. (See pl. 4, A.) In these places where the rocks are less limy they weather slate-gray rather than buff.

The oil shale that characterizes the lower oil-shale group occurs in beds ranging in thickness from a fraction of an inch to about 8 feet. Most beds, however, are $1 \frac{1}{2}$ to 3 feet thick. The probable yield of oil differs from bed to bed, but few if any beds 3 feet or more thick will yield more than 35 gallons to the ton, Nearly all the beds over 1 foot thick have an estimated potential yield between 10 and 25 gallons to the ton. Most of them are massive, but a few are papery or have papery phases. The massive beds are nearly black or very dark reddish brown on the fresh surface and weather dark to light bluish gray. Some beds show almost no bedding, but most of them are finely banded with lighter-gray or yellowish-buff' layers of leaner and more limy oil shale and appear laminated.

The irregularities of bedding in the oil shale range from slight undulations or loop bedding or discontinuity of the layers without any appreciable waviness to excessive mosaic brecciation and intricate plications due to differential compaction. (See pls. 14, A, and $15, A$.) Another common feature of the oil-shale beds in this unit is a speckled or finely mottled appearance due to flakes or short, very thin lenses of barren cream-colored or ash-gray marlstone. These limy inclusions range in size from dustlike particles up to 
films or layers several inches long. Small lentil-like or irregular limy concretions, mostly dark yellowish brown, are associated with these inclusions but are distinct from them. Locally also there are black chert concretions in the oil-shale beds. Mud cracks are not plentiful. Edgewise conglomerate, mudstone lumps, mud curls, ripple marks, and ripple bedding are rare or absent.

Some beds of oil shale are exceedingly variable along the strike, changing abruptly not only in thickness but also in structure, from massive to papery or the reverse. Locally, as along Piceance Creek, 'massive beds contain a great many lenses of papery oil shale, and some papery beds contain stubby lenses of massive oil shale. Only one or two beds in the lower oil-shale group show distortion by the growth of large radial aggregates of salt that crystallized out in the plastic ooze that later hardened and became shale.

Paper shale containing more or less organic matter is fairly abundant in this unit. It is most plentiful along Piceance Creek, where it makes up about 35 per cent of the group. There is less at Cathedral Creek and only about 2 per cent along the White River in Utah. The largest part of the group, however, consists of hard platy marlstone and a smaller amount of somewhat softer flaky shale. In these materials most of the bedding is regular, but locally it is wavy or distorted by differential compaction, especially in the thicker beds. Much of this marlstone contains a small amount of organic matter that ranges from a trace up to enough to yield a few gallons of oil to the ton. The organic matter may be uniformly distributed, giving the fresh rock a pale chocolate-brown color, or it may be distributed in layers that range in thickness from mere films to some several inches thick. Only a little of the marlstone is sandy.

Along the White River in Utah about 49 per cent of the lower oil-shale group consists of larvae-bearing beds. These are beds of oil shale that contain innumerable remains of fly larvae, most of which are about an inch in length, although some are only about oneeighth inch and others nearly 2 inches. Some of the families and genera to which these larvae belong are given on pages $50-51$. They cover nearly every bedding plane and in places are so abundant that they make glossy dark-brown layers or partings between the thin beds of rock. The bedding planes bearing larvae are either regular or only slightly undulating and about 0.1 inch apart. The larvae-bearing shale is chocolatebrown or gray-brown, and some of it is capable of yielding 8 to 15 gallons or more of oil to the ton. (See pl. 2, B.)

Limestone makes up but a very small part of the lower oil-shale group. Most of it is muddy, hard, thin bedded, and platy and occurs in zones a few inches to several feet thick. It weatbers cream-colored or ocher-yellow.
Sandstone is rare or absent in the lower oil-shale group. Most of the beds are very fine grained or muddy and are interbedded with shaly mudstone. There are a few beds less than 5 inches thick that are remarkably persistent. Closer study has shown that some of these are beds of volcanic ash that have changed to zeolites. Probably many of the others are also beds of similar altered ash.

Scales and partial skeletons of garpike (Lepidosteus sp.) are locally abundant in the low-grade oil shale of this unit. Ostracodes are also numerous in some of the limestone beds. At one place only were fragments of plant stems found.

Transitional beds.-Between the lower and upper oil-shale groups of the Parachute Creek member is a relatively thin unit of transitional beds consisting predominantly of marlstone that is nearly barren of. organic matter. (See pl. 7.) These beds, however; indicate a distinct phase in the history of the Green River lake. In most places they weather buff or gray and make either broken, steplike ledges or, where softer, smooth slopes interrupted by ledges. They range in thickness from 43 to about 118 feet.

The marlstone of these beds is either hard and platy or somewhat soft and shaly. Much of it is finely laminated, and some is even papery. The marlstone varies from place to place. In the vicinity of Cathedral Creek much of it is sandy, but along the White River in Utah it is only slightly sandy and rather soft and shaly. As in the rocks below, much of the socalled barren marlstone and shale contains a small quantity of organic matter that is either distributed uniformly or segregated in layers. There are also a few beds of hard greenish-gray mudstone that contain considerable $\mathrm{FeS}_{2}$, most of which is marcasite.

Oil shale occurs but sparingly in the transitional beds. Along Cathedral Creek there are several beds of lowgrade oil shale which, curiously enough, are burned in a few places at the outcrop. On Piceance Creek the unit contains several very thin beds of rich massive oil shale. These are elongate lenses, rarely more than 1 inch thick, and are intercalated with thick units of nearly barren marlstone.

Limestone and sandstone occur locally in thin beds. Much of the limestone is muddy and slightly organic. The sandstone, which was found only in the Parachute Creek section, is fine grained, muddy, and limy.

Some of the oil shale shows mosaic brecciation. Mud curls and waterworn fragments of shale and claystone occur locally in the sandy limestone. One sandstone bed showed contorted bedding and small ripple marks. No mud cracks were observed in this unit. Plant fragments and adult insects were observed in several places, but only one bed, along the White River in Utah, was found to contain fly larvae.

Upper oil-shale group.-The upper oil-shale group contains most of the rich oil-shale beds in the Green 
River formation and is therefore the object of greatest economic interest. (See pl. 7.) . It is a single unit that is coextensive with the formation in Colorado and Utah except for the shore facies in the Gray Hills north of the White River: It ranges in thickness from about 87 feet along the White River in Utah to more than 730 feet in the vicinity of Parachute Creek. In much of the area east of Bitter Creek the upper oil-shale group makes a high, nearly vertical cliff that is a conspicuous feature of the landscape. (See pl. 2, A.) This cliffforming tendency is due in part to the extreme resistance that the massive beds of rich oil shale offer to weathering and in part to the fact that much of the low-grade oil shale of this group is very limy and hard. The rocks weather prevailingly light gray or gray-buff but are more or less distinctly banded with dark bluish gray.

Oil shale makes up 29 to 38 per cent of the group, and much of this will yield more than 20 gallons of oil to the ton. (See pl. 13.) Nearly all the oil shale is massive, but some weathers papery. The massive oil shale that will yield 20 to 25 gallons of oil to the ton occurs in beds from a fraction of an inch to 9 or 10 feet thick. These weather dark bluish gray to almost black, but are always finely lined with lighter-gray or buff lines that indicate thin bedding. The rock, however, is truly massive, as it breaks across these minute bedding laminae. On the fresh surface the high-grade oil shale is either very dark gray finely lined with black layers that have a satiny luster or entirely black with a satiny . luster or dark reddish brown.

The buff bands in the massive oil shale may be mere fragmentary films that occur but rarely or they may be an inch or more thick and make up an appreciable part of the bed. Most of them are slightly lenticular, and in many beds they are accompanied by small limy concretions. In some beds the concretions consist of black chert. Locally a great many beds of oil shale show mosaic brecciation, but in the vicinity of Parachute Creek that structure is rare.

Some of the oil-shale beds are massive with papery phases. These beds also are finely laminated and contain thin limy layers and concretions. Locally they show mosaic brecciation.

In addition to the richer beds there are some that range in potential yield from about 10 to 20 gallons of oil to the ton. Most of these beds are papery or platy, but some are massive and very hard. Their poorer quality is generally indicated by greater weight and yellowish-gray or distinctly yellow weathered surface. They are also lighter colored on a fresh fracture.

East of Bitter Creek many of the oil-shale beds include ellipsoidal cavities ranging from about an inch to nearly 5 feet in length, which originally contained salt aggregates that apparently formed before the beds had completely hardened. The bedding is greatly distorted by these cavities. (See pl. 5, B.) Some have fillings of calcite that are evidently the molds of large radial aggregates of bladed salt crystals. (See pl. 6, A.) Very similar radial molds occur also in the low-grade oil shale of this group. These range from a fraction of an inch to several inches in diameter. Although some of the molds are sharp, no satisfactory measurement could be made to determine the original crystals, because they are so complexly intergrown. Molds of somewhat similar bladed crystals locally cover the bedding planes. (See pl. 6, B.)

Contorted bedding is a common structure in the oilshale beds and also in some of the more massive marlstone beds in the Piceance Creek Basin. Along the White River in Utah it is rare. The folding in some beds is simple and very. regular, the axial planes being nearly parallel to the normal bedding. In other beds the folding is exceedingly complex. (See pl. 14, A.) Minute faults also occur in the same kinds of rocks, but few were found closely associated with the beds that were contorted by differential compaction. Mosaic brecciation is a distinct structure which is only very rarely associated with the contorted bedding.

The remainder of the upper oil-shale group consists almost wholly of slightly organic marlstone similar to that in the lower parts of the formation but a little harder and somewhat richer. These leaner beds have been tested, and most of them will yield 4 to 10 gallons of oil to the ton. (See pl. 13.) Paper shale is not plentiful in the upper oil-shale group. The quantity of limestone is insignificant, and there are only a few sandstone beds. These are thin but persistent, and some of them have been confused with beds of altered volcanic ash.

Along the White River and in Hells Hole Canyon, north of Watson, Utah, the upper oil-shale group contains near its base two analcite beds. One bed consists of lenses one of which is about 40 feet long and 3 feet 3 inches thick at its thickest place. This lens comes into the middle of a rather rich bed of oil shale. The other bed is 13 feet above the lenticular one and is about 4 inches thick. It seems to be fairly persistent, but it was not studied with particular care in the field, as its unusual composition was not recognized until specimens were studied in the office. It lies between two beds of low-grade oil shale but is strongly saturated with bitumen, which exudes from it in minute droplets. These peculiar zeolite beds, which are alteration products of volcanic ash, have been treated fully in another report. ${ }^{41}$

Mud cracks are common in this unit, but mud curls, mudstone lumps, and ripple marks are rare.

Fly larvae are extremely abundant in the upper part of the upper oil-shale group on Parachute Creek, where there are more than 120 feet of larvae-bearing beds. Larvae were also found in this group along Piceance

4t Bradley, W. H., The occurrence and origin of analeite and maerschaum beds in the Green River formation: U. S. Geol. Survey Prof. Paper 158, pp. 1-7, 1929. 
Creek and along the White River in Utah. Adult insects, fragmentary leaves, and stem impressions also occur in this group, but they are not plentiful.

\section{EVACUATION CREEK MEMBER}

The uppermost lithologic unit of the Green River formation is the Evacuation Creek member, so named because of the excellent exposures on Evacuation Creek, Utah, and because in that locality it is a definite and readily mappable unit. (See pl. 8.) In the vicinity of Piceance Creek it is at least 840 feet thick and is overlain by about 400 feet of beds that are dominantly sandy. No fossils have been found in these uppermost sandy beds, but they are lithologically and stratigraphically equivalent to the basal part of the Bridger formation of the Uinta Basin and are here tentatively assigned to that formation. In the Uinta Basin the Evacuation Creek member is also a definite unit and along the White River in Utah is about 530 feet thick.

This member consists chiefly of barren shale and marlstone that weather brown or brownish gray, and in most places it makes gently rounded slopes broken by irregular and discontinuous ledges. Most of the shale is limy, thin bedded, and platy or irregularly chippy. Locally it is sandy. In the vicinity of Piceance Creek more or less sandy marlstone makes up nearly one-third of the unit, and groups of fine to medium grained dark-brown sandstone beds alternate with the marlstone. In other parts of the area east of Bitter Creek the marlstone of the unit is sandy, but sandstone is not so abundant. Locally there are thin beds of soft claystone. The Evacuation Creek member also contains a few thin beds of rich oil shale similar to those in the Parachute Creek member. They are nearly everywhere too thin and too discontinuous to be considered workable deposits.

Along Parachute Creek in Colorado and the White River in Utah the Evacuation Creek member contains numerous salt cavities. (See pl. 5, A.) Many of the oil-shale beds and a few of marlstone and muddy sandstone show contorted bedding, but shale breccias, mudstone lumps, and mud cracks are not so abundant as in the Garden Gulch member. At one place near the top of the section on the White River in Utah mud cracks were found on the upper surface of a bed of low-grade oil shale, and in another place mud cracks occur on a bed of sandstone marked with oscillation ripples. Several other beds of sandstone show oscillation ripples, but current ripples and cross-bedding are rare.

Most of the finely preserved adult insects and leaves of the Green River formation came from the lower part of the Evacuation Creek member. Larvae-bearing beds are also abundant in the lower part.
DELTA AND BHORE FACIES

A shore and delta facies of the Green River formation constitutes the Gray Hills, north of the White River in Colorado. This facies is chronologically equivalent to most of the formation described above, but as none of the lithologic units recognized south of the White River have been surely identified north of the river, the exact equivalence of the facies is unknown. Two complete sections north of Deep Channel Creek are about 1,100 and 1,175 feet thick. (See pl. 8.) The shore facies in that locality is a little less than one-half as thick as the section measured about 15 miles farther south along Piceance Creek, and probably therefore some of the upper part has been eroded, although the relative thinness of the shore facies is probably also to be explained by breaks in sedimentation.

Nearly 50 per cent of the shore facies north of Deep Channel Creek is sandstone. The sandstone beds form groups 10 to 80 feet thick, which alternate with shale units of about the same size. The shale is monotonously uniform, being either gray or grayish-buff, soft, flaky, and prevailingly sandy. A little of it is hard and platy. The sandstone is less uniform. Its colors range from nearly white through gray, buff, and yellowish brown to dark reddish brown, but light-gray or buff hues predominate. Most of the sandstone is fine or medium grained, but locally it is coarse grained and contains varicolored chert pebbles'as much as half an inch in diameter. Gravel of this kind is rather plentiful near the base along the east face of the Gray Hills. In a few places there are also coal lumps in the sandstone. Most of the beds are massive and broadly lenticular. Some are regularly bedded, and a fewthe more muddy and harder beds-are platy. There is more ripple bedding than cross-bedding; oscillation ripples are only moderately abundant. Many of the beds of siltstone and muddy sandstone show mud cracks, mud curls, and mudstone lumps, a few of which are waterworn.

There are several noteworthy algae reefs in the upper part of this facies, but beds of limestone and oolite are rare. Most of the limestone beds are brecciated.

Ostracodes are abundant in some of the sandstone beds. The shale contains a few fragmentary leaves and stems and locally also ostracodes and Estheria? shells. Some of the thin limestone beds consist largely of gastropod shells. Scattered crocodile and turtle bones, garpike scales, and the bones and teeth of other fish were also found.

Southward along the Gray Hills the shore facies changes gradually; shale, oolite, and marlstone become more abundant; the sandstone becomes finer grained, thinner bedded, and more muddy and limy; and the shale becomes less sandy and more evenly and distinctly bedded. Paper shale and thin beds of oil shale 
also appear. There is therefore a complete gradation southward from the very sandy shore and delta facies into the typical formation of the Piceance Creek Basin.

\section{COLUMNAR SECTIONS}

Plate 7 shows a columnar section of the Green River formation that was measured in the canyon of Parachute Creek, Colo. It is a composite section measured in four parts. The base of the section is in sec. 4, T. 6 S., R. 96 W., and the top in sec. 10 , T. 5 S., R. 96 W. As the parts of the section were correlated by tracing some single bed which had a distinctive topographic expression, the error in correlation is probably small. A Brunton compass was used as a hand level to measure the section, but a great many of the beds were measured with a 6-foot steel tape. This section contains the type sections of the Garden Gulch and Parachute Creek members. It also has particular significance for the specific study whose results are recorded here, because it represents the locality of greatest accumulation of oil shale in the basin of the ancient Uinta Lake. Plate 8 shows another composite section of the Green River formation. The lower part of this section, with the exception of a sandstone bed at the top, which is about 73 feet thick, was measured along the road from Fruita to Rangely, Colo., from a point near the head of Trail Creek to the top of the divide between Trail Creek and West Douglas Creek. The upper part of the section, including at the base the thick sandstone bed just mentioned, was measured on the north side of Cathedral Creek in sec. 26, T. 3 S., R. $99 \mathrm{~W}$., Rio Blanco County, Colo. The two parts of this section are widely separated, and their correlation is therefore doubtful, but nevertheless the writer believes that the interval not represented at the top of the Douglas Creek member is rather small.

Plate 8 also shows a composite section that illustrates the lithology typical of the Green River formation in the extreme eastern part of the Uinta Basin. The lower part of this section was measured in Hells Hole Canyon, in sec. 22, T. 10 S., R. 25 E. Salt Lake meridian, and the upper part in the canyon of the White River in sec. 27 , T. 9 S., R. 25 E., both in Uintah County, Utah. As measured in the field the two parts of this section overlap, and by matching several distinctive groups of beds it was possible to correlate the two parts so that the composite section is a complete cross section of the formation for that vicinity. At the top this columnar section contains the type section of the Evacuation Creek member. Plate 8 also shows a columnar section of the Green River formation measured a few miles north of Deep Channel Creek in secs. 29 and 30, T. 4 N., R. 95 W., Moffat County, Colo. This section illustrates the lithology of the delta and shore facies that make up the Gray Hills of that vicinity.
ROCKS WEST OF BITYER CRERK, MRTAH

DUCHESNE-UINTAH COUNTY LINE SECTION

West of Bitter Creek the lithologic units of the Green River formation are different from those recognized in Colorado and the extreme eastern part of Utah near Watson. Only the upper oil-shale group of the Parachute Creek member has been traced continuously across the region between Watson and that part of the Uinta Basin west of Bitter Creek. Two detailed sections were studied in this part of the Uinta Basinone on the north side of Minnie Maud Creek, near the Duchesne-Uintah County line, and the other a composite section in Indian Canyon along the post road from Castlegate to Duchesne. These sections are so different from each other and so unlike the formation east of Bitter Creek that they can best be described separately.

The section on Minnie Maud Creek is not complete. By comparison with the section 13 miles to the west, in Gate Canyon, the writer estimates that about 300 feet at the base is not exposed. But the remainder of the section on Minnie Maud Creek is excellently exposed and may be divided, for convenience of description, into two parts. The lower part or delta facies is about 440 feet thick and contains about 52 per cent of sandstone; the upper part is about 900 feet thick and consists principally of marlstone and shale.

Delta facies.-The delta facies makes the walls of the narrow inner canyon along Minnie Maud Creek. (See pl. 9, B.) It also makes the walls of a great number of short side canyons such as Gate, Petes, and Water Canyons. Most of the sandstone beds of this facies are medium grained, somewhat muddy, dark yellowish brown or olive-brown, and either crudely platy or massive. They contain an abundance of muscovite and some biotite. Many are cross-bedded or ripple bedded and fill shallow channels in the beds below. In a few the bedding is highly distorted, and in two places the writer measured dips as steep as $35^{\circ}$. (See pl. 9, A.) The sandstone beds range in thickness from about 1 foot to 55 feet. One thick bed that is greatly contorted contains several large lenticular blocks of oil shale and evenly bedded marlstone and also many small shreds-1 inch to several inches long-of very rich oil shale. (See pl. 10,A.) Some beds are very fine grained, muddy or limy, light gray to brown, and regularly bedded; others are coarse grained, light gray to white or very ferruginous, and variable in thickness. A few thin beds are saturated with bitumen. Mud curls, clay pellets, and waterworn mudstone fragments are plentiful in the sandstone beds in this part of the section. Current ripples are abundant, but oscillation ripples are rare.

Much of the shale in this facies is light brown to ashgray and flaky, but there are also many distinctly and finely laminated or even papery beds that contain some 
organic matter. In some of the marlstone beds organic matter is distributed uniformly; in others it is segregated in thin layers. There are also several beds of rather hard sandy and micaceous greenish-brown mudstone that show little or no bedding. The weathered outcrop of these beds is spheroidal, because the material spalls off in much the same manner that some homogeneous igneous rocks weather. Some of the limiest marlstone beds contain mud curls and edgewise conglomerate.

About 100 feet below the rim of the inner canyon that marks the top of the lower sandy part of the formation there are several rich oil-shale beds intercalated with thick beds of sandstone. These represent the upper oil-shale group of the Parachute Creek member. Where this section was measured it contains only three beds that have any probable economic interest. Each is about 3 feet thick and will yield 15 to 25 gallons of oil to the ton. These beds, however, are not regular. They have been distorted, broken, and pinched off by differential compaction that occurred soon after they were deposited. (See pl. 10,A.) Interbedded with them are several considerably thinner beds, which the writer estimates to range in potential yield from about 10 to nearly 40 gallons of oil to the ton. Some are papery and scabrous, but most of them are hard and massive and show unusually good mosaic brecciation.

Upper shaly facies.-The upper shaly facies of the formation is about 900 feet thick. It is interrupted a little above the middle by a group of hard sandstone beds, here named the Horse Bench sandstone lentil, which makes a remarkably smooth and extensive bench or table-land. (See pl. 9, B.) Below this bench the shale makes a steep slope down to a narrower bench at the top of the inner canyon. Above the Horse Bench sandstone there is a similar shale slope up to the base of the Bridger formation.

Grayish-brown shale and shaly marlstone, much of which is sandy and either regularly laminated or rather crudely flaky, makes up the larger part of the shaly unit below the Horse Bench sandstone. There are also some hard platy marlstone beds, a larger amount of hard greenish-gray micaceous mudstone that weathers spheroidal, and a few zones of very soft buff shale. Above the Horse Bench sandstone hard drab, either uniformly colored or faintly banded mudstone which weathers spheroidal and contains much marcasite is most plentiful, but chocolate-brown soft flaky shale also occurs.

In the lower part of the upper shaly facies beds of fairly rich oil shale 3 to 8 inches thick occur sparingly. Most of them are massive and show mosaic brecciation, but a few are papery and scabrous. Only a few thin beds of shale or marlstone above the Horse Bench sandstone contain organic matter, and they are very lean. About 250 feet below the top of the Horse
Bench sandstone are three thin beds of low-grade papery. oil shale that contain abundant fly larvae.

Sandstone makes up less than 9 per cent of the upper shaly facies of this section. The Horse Bench sandstone includes about half of it, and the rest occurs either as single thin regular beds or as small groups of beds. Most of it is fine grained, hard, thinly and evenly bedded, and micaceous. Muscovite is more plentiful than biotite, but in a few beds fresh black biotite is abundant. Perhaps these contain considerable volcanic ash. The colors of the sandstone range from light gray to nearly black in the more limy beds and from buff to dark reddish brown in the ferruginous beds.

The Horse Bench sandstone is about 55 feet thick and consists of nearly equal groups of thin-bedded and ripple-marked sandstone beds that alternate with a lesser amount of hard greenish-gray micaceous and sandy mudstone. About 15 feet of similar but thin and obscurely bedded mudstone separates the two sandstone groups. The whole unit is much more resistant than the associated rocks and makes a very conspicuous topographic feature. (See pl, 9, B.) Because it forms the broad table-land between Minnie Maud Creek and Jack Canyon, known as Horse Bench, the writer has named it the Horse Bench sandstone lentil. It is about 475 feet below the top of the formation and about 500 feet above the principal oil-shale beds. It makes a very convenient horizon marker and has been traced about 25 miles west and about 20 miles east from the Green River and probably could be traced many more miles in each direction.

Limestone is very rare in the upper shaly facies, despite the abundance of lime in the beds of marlstone, shale, and sandstone. There are, however, two thin algae reefs at the top of the formation.

Mud cracks are remarkably plentiful, having been found at 27 horizons in the upper 900 feet of the formation. Moreover, at most of these horizons more than one bed is mud cracked, and at many there are several hundred thin beds, a quarter of an inch to 2 inches thick, that are mud cracked. Mud curls and rain prints accompany some of the mud-cracked beds. Current ripples are very numerous in the beds of sandstone and sandy shale, but oscillation ripples are more rare. Some unusually fine sharp-crested oscillation ripples with well-formed medial ridges were found at the top of the Horse Bench sandstone.

Plant fragments were found at only two places.

The complete absence from this section of the molds of salt crystals, in comparison with their abundance at other localities, is worthy of note.

\section{GATE CANYON BECTION}

In the vicinity of Gate and Argyle Canyons the writer examined the formation and estimated the thick- 
ness of the larger units. A comparison of the rocks at these places with those just described is interesting. At the base, in the northeastern part of T. $12 \mathrm{~S}$., R. $13 \mathrm{E}$. Salt Lake meridian, there is a predominantly shaly unit which consists of thin-bedded gray and greenish-gray shale with a lesser amount of evenly bedded fine-grained limy sandstone. It also contains many beds of ostracode-bearing shale and limestone and a few beds of nearly black papery low-grade oil shale which also contain ostracodes.

A sandstone facies 500 to 600 feet thick overlies the basal part. It makes the deep, narrow canyon of Minnie Maud Creek and is the westward extension of the delta facies near the Duchesne-Uintah county line. However, in the vicinity of Gate Canyon it contains 75 to 80 per cent of sandstone. The sandstone is fine to medium grained, dark brown, and somewhat muddy. Many of the beds are massive and variable in thickness, but some are thin bedded and platy. Many also are cross-bedded or ripple bedded; some contain bottom-set, foreset, and topset beds, and others fill shallow channels cut into the beds below. The cross-bedding in one muddy channel sandstone is inclined $21^{\circ}$ from the normal bedding planes. Thin regular beds of hard greenish-gray mudstone are interbedded with the sandstone of this facies. A few red mudstone partings were also found.

Westward, up Argyle Canyon, the sandstone facies changes; beds of hard, evenly bedded greenish-gray mudstone with thin red bands replace sandstone beds and compose about half of the unit.

About 1,000 feet of shale and marlstone similar to the upper shaly facies 13 miles to the east, near the Duchesne-Uintah county line, makes the remainder of the formation at Gate Canyon. It also contains the Horse Bench sandstone, which is nearly identical with that farther east near the Green River.

\section{INDIAN CANYON SECTION}

The composite section along Indian Canyon is complete. It is about 4,900 feet thick and is the thickest known section of the Green River formation. It contains two tongues at the base-one, which presumably disappears westward, is lacustrine, and its lithology is characteristic of the basal member of the Green River formation; the other, which disappears eastward, overlies the lacustrine rocks and is identical in lithology with the Wasatch formation, to which it probably belongs. The rest of the Green River formation may be divided for convenience of description and interpretation into four distinct units-(1) the second lacustrine facies, which overlies the tongue of the Wasatch formation, (2) a thick delta facies, (3) an oil-shale facies, and (4) at the top a thick barren and saline facies. (See pl. 11.)

Tongue of Green River formation.-The basal part, a tongue of the Green River formation, is about 200 feet thick and consists mostly of light chocolate-brown flaky or paper shale with an abundance of cyprid ostracodes and hard gray platy marlstone that locally contains gastropod and thin pelecypod shells. Limestone, consisting mostly of ostracodes, and hard gray. mudstone, together with several thin beds of darkcolored shell marl that contain Goniobasis, Anodontalike shell fragments, and ostracodes, make up about 20 per cent of this unit. It also includes a small amount of carbonaceous shale and two thin beds of coal. Sandstone is rare, and only a little of the shale and marlstone is sandy. Very few beds contain enough organic matter to be considered low-grade oil shale. Oolitic beds are absent, and there is but one small and completely silicified algae reef.

Tongue of Wasatch formation.-The tongue of the Wasatch formation is about 380 feet thick and consists of drab, buff, greenish, and red mudstone with rather numerous thick lenticular beds of medium to coarse grained sandstone. Most of the sandstone beds are massive, but a few are cross-bedded. Their colors range from nearly white to dark reddish brown, but yellowish brown predominates. At the base and top of the tongue of Wasatch beds the changes in lithology. are transitional.

Second lacustrine facies.-The tongue of the Green River formation at the base represents the first lake stage; the lithologic unit above the tongue of the Wasatch formation represents the second and is called the second lacustrine facies. It is not greatly different from the basal unit but lacks the beds of carbonaceous shale, coal, and shell marl. It is about 750 feet thick and consists predominantly of shale, much of which is light gray or light grayish brown and flaky. A little is soft and papery. There is also some hard platy marlstone with delicate color banding. Only a few beds are sandy. Many of the beds, especially the chocolate-brown, papery, and flaky ones, contain great numbers of ostracodes. These beds are very low grade oil shale. A little above the middle of the unit, in the lower part of a low but persistent cliff, is a massive oil-shale bed which the writer estimates will yield about 20 gallons of oil to the ton.

Most of the limestone of the second lacustrine facies is thin and rather poorly bedded, light brown to buff, and muddy. A few beds are sandy; others are soft and earthy and might. be regarded simply as marl. Many contain abundant ostracodes, and some near the top of the facies contain numerous fishbone fragments. Mud cracks are also plentiful in those beds that contain the bone fragments.

All the sandstone of this unit is very fine grained, limy, and micaceous. Most of it is thin and evenly bedded, but a little is cross-bedded or ripple bedded. Yellowish gray and dark reddish brown are the prevailing colors. 
Delta facies.-The delta facies is about 1,875 feet thick and makes up a little more than one-third of the formation in this part of the Uinta Basin. More than 75 per cent of the facies consists of hard sandy and micaceous grayish or brownish-green mudstone in fairly regular beds a few inches to 2 or 3 feet thick which are either homogeneous or vaguely laminated and which exfoliate so that the weathered face consists of many spheroidal surfaces. Locally thin regular bands of brick-red or maroon mudstone or flaky shale alternate with the greenish beds.

Most of the sandstone of the delta facies is fine grained, muddy, micaceous, and light to dark gray, and forms rather regular beds from a few inches to about 1 foot thick. Many beds are gently cross-bedded or ripple bedded, but some are massive. Thick irregular lenses of fine to medium grained buff or brown sandstone are plentiful in the lower 350 feet of the facies. They rest in channels cut into the beds below and grade laterally into hard sandy greenish mudstone. A few of them contain very unusual conglomeratic lenses whose subangular to well-rounded pebbles of shale and claystone are firmly bound in a matrix of calcite in which there is some sand. These lenses of conglomerate contain many fragments of the carapaces and bones of turtles, the teeth and bones of crocodiles and fish, large garpike scales, pieces of carbonized wood and leaves, and the impressions of pelecypod shells.

Interbedded with the greenish mudstone and finegrained sandstone are rather numerous thin massive beds of marlstone. These are dense and buff; light chocolate-brown, or pinkish gray. Some, however, are greenish gray, sandy and micaceous, and crudely bedded or platy; others are soft, earthy; and ocherous. Several layers contain mud curls or mud cracks. One bed contains many palm-leaf and stem impressions.

Papery shale, evenly laminated, or flaky shale makes up only about 1 or 2 per cent of the delta facies, and most of that is in the lower few hundred feet. It is gray or light chocolate-brown, rather soft, and limy. Some beds are sandy; others somewhat carbonaceous.

Oil-shale facies. - The oil-shale facies is about 380 feet thick and contains many thin beds of oil shale, most of which are papery or have thin platy bedding. A few are massive, and nearly all show excellent mosaic brecciation. They are brown to black and weather ash gray to purplish gray. One bed near the base of the unit is of minable thickness, 4 feet 8 inches, and would yield, as estimated, 25 to 30 gallons of oil to the ton. The lower part of this bed is papery and tough but only moderately rich; the very rich upper part is tough and slightly contorted and weathers purplish gray. The rest of the oil-shale beds range in thickness from 4 inches to about 1 foot. Near the top of the unit a thin bed of rich oil shale is very clearly mud cracked. Another thin bed of rich oil shale about 50 feet lower in the unit contains abundant fly larvae, the only ones found in the Indian Canyon section.

The greater part of the oil-shale facies consists of barren or very lean gray or light-brown flaky shale. Some beds of marlstone are hard, sandy, and platy; others are soft and somewhat clayey. Thin beds of gray to brown very fine grained sandstone or siltstone are interbedded with the marlstone, shale, and oil shale. A few of them are cross-bedded or ripple bedded, and some show small oscillation ripples. Mud cracks and mud curls were found in some beds of shale and sandy mudstone. The oil-shale facies contains only a few thin beds of limestone. These are hard, dense, and muddy or sandy.

Barren and saline facies. - The barren and saline facies is about 1,700 feet thick and makes up the remainder of the Green River formation. Almost all of the upper half of this unit represents a distinctly saline stage of the lake. Calcite pseudomorphous after glauberite(?) and anhydrite(?) and empty molds of these crystals are extremely abundant in that part. Mud-cracked bedding planes are remarkably numerous.

More than 90 per cent of this facies consists of lean or barren shale and marlstone. Beds or groups of beds of soft clayey finely flaky shale alternating with beds of harder sandy marlstone having thin platy bedding predominate. The colors of these rocks are light brownish or greenish gray, buff, brown, and brownish pink. Shades of gray and brown prevail. Some beds are massive but show faint color banding that indicates bedding laminae; others are papery.

Calcite fillings of glauberite(?) molds make up as much as half of some of the shale beds. Most of the crystals are less than one thirty-second of an inch long, but in a few beds there are salt crystal molds about five-eighths of an inch long. The mud cracks of some beds are filled with small salt pseudomorphs. (See pl. 10, B.) A few beds contain innumerable radiating bundles of thin bladelike crystal molds. Beds of sandstone and limestone also contain crystal molds. These salt-crystal molds and their significance are discussed more fully in another report. ${ }^{42}$

Mud cracks were recorded at 38 different horizons in the barren and saline facies, and at nearly all of these horizons many rather than a few bedding planes showed the cracks.

Oil-shale beds in this facies are few and of poor quality. One near the top of the saline zone which the writer estimates would yield 15 to 20 gallons to the ton is 4 feet thick; another richer bed, but only 1 foot 6 inches thick, is just below the saline zone. Other oil-shale beds are thinner and less rich.

A few beds of muddy or sandy limestone are interbedded with the oil shale, marlstone, and sandstone.

12 Bradley, W. H., The occurrence and origin of analcite and moerschaum beds in the Green River formation: U. 8. Geol. Survey Prof. Paper 158, p. 5, 192. 


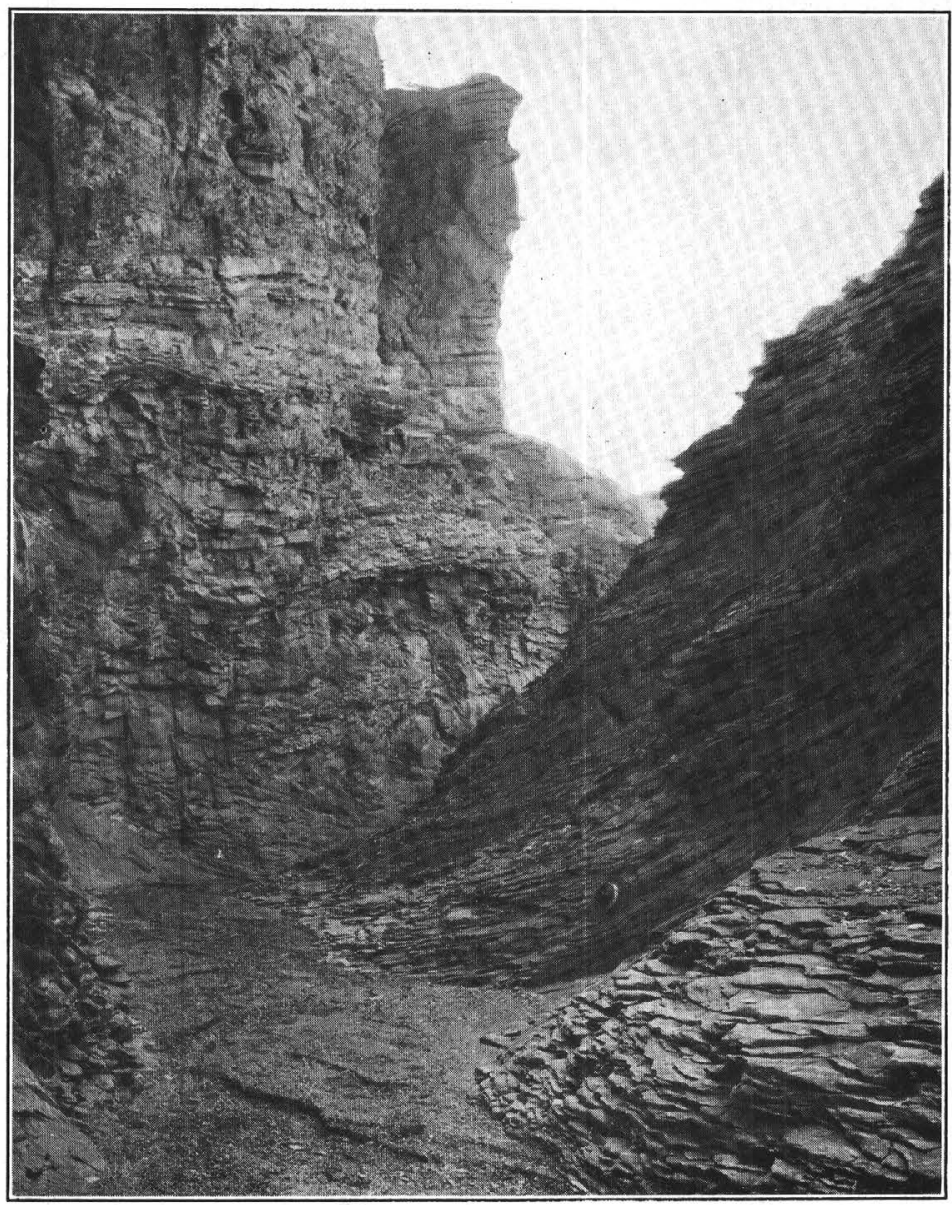

A. STEEP FALSE BEDDING IN A FINE-GRAINED MUDDY SANDSTONE OF THE DELTA FACIES IN A SMALL CANYON TRIBUTARY TO MINNIE MAUD CREEK NEAR THE DUCHESNE-UINTAH COUNTY LINE, UTAH

The steepness of the bedding is local and apparently due to differential compaction.

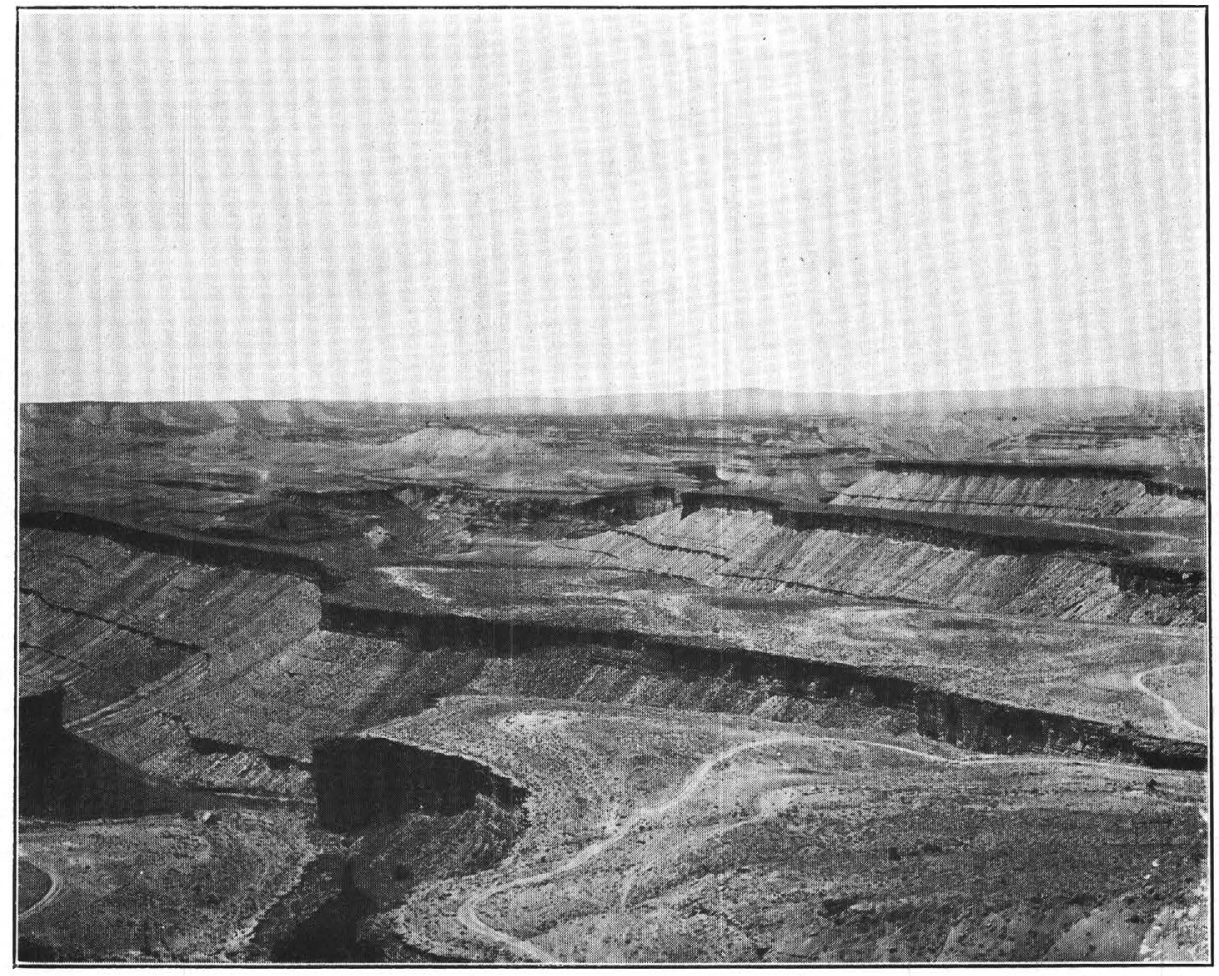

B. VIEW SOUTHWEST ACROSS THE VALLEY OF MINNIE MAUD CREEK NEAR THE BOUNDARY BETWEEN DUCHESNE AND UINTAH COUNTIES, UTAH

The remarkably flat bench is the top of the Horse Bench sandstone lentil. The inner canyon of Minnie Maud just below the rim of the inner canyon. The road in the foreground furnishes a scale. 




A. LARGE LENS OF OIL SHALE AND ORGANIC MARLSTONE IN THE MUDDY SANDSTONE OF THE DELTA FACIES OF THE GREEN RIVER FORMATION NEAR THE DUCHESNEUINTAH COUNTY LINE

Lens shown by white line. By differential compaction the top of this lens has been depressed several feet below its original position, which is indicated at the right.

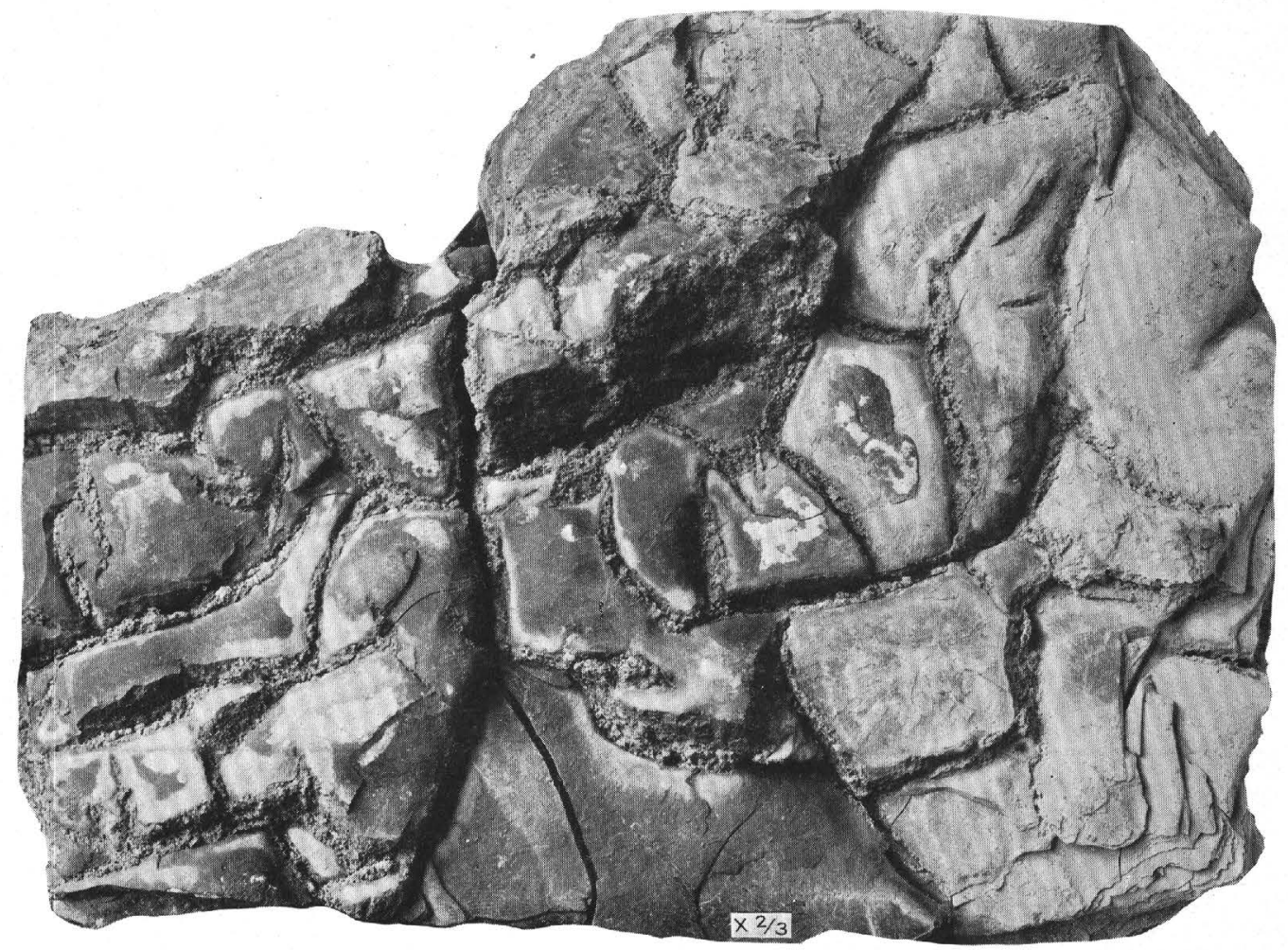

B. MUD-CRACKED ORGANIC MARLSTONE BED FROM INDIAN CANYON, UTAH

Small calcite pseudomorphs of a salt, probably glauberite, fill the cracks. Note the marked convexity of the polygon surfaces. 


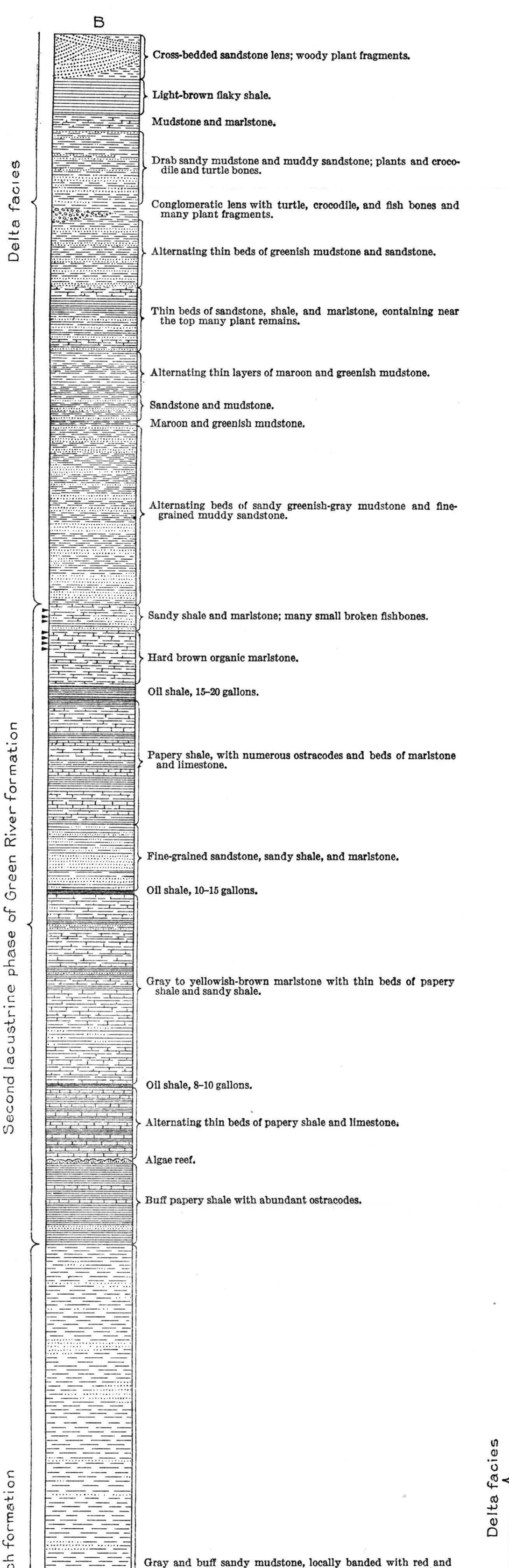

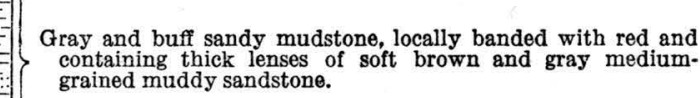

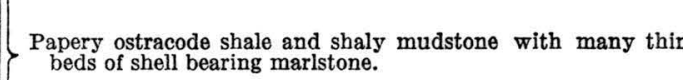

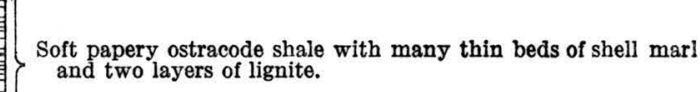
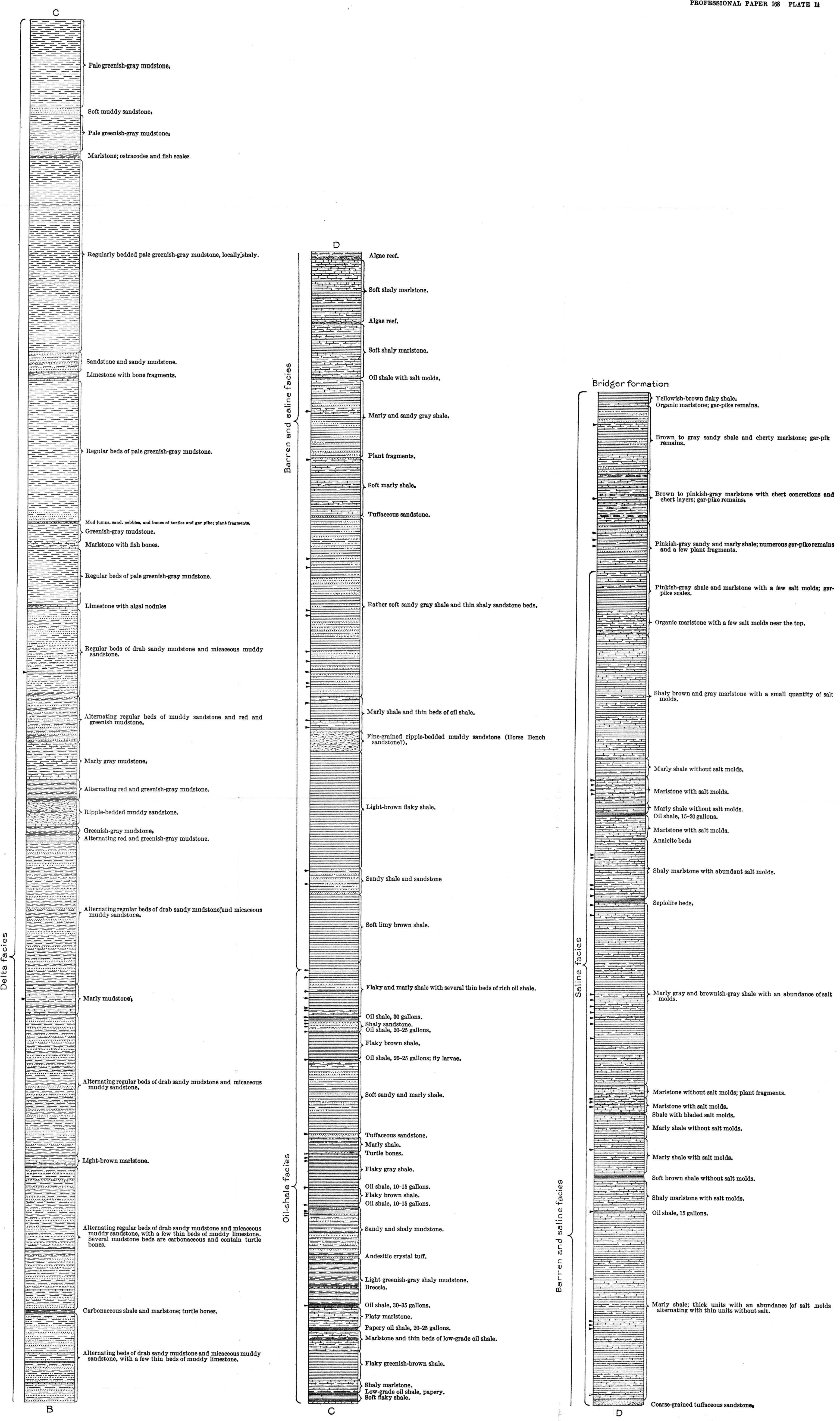


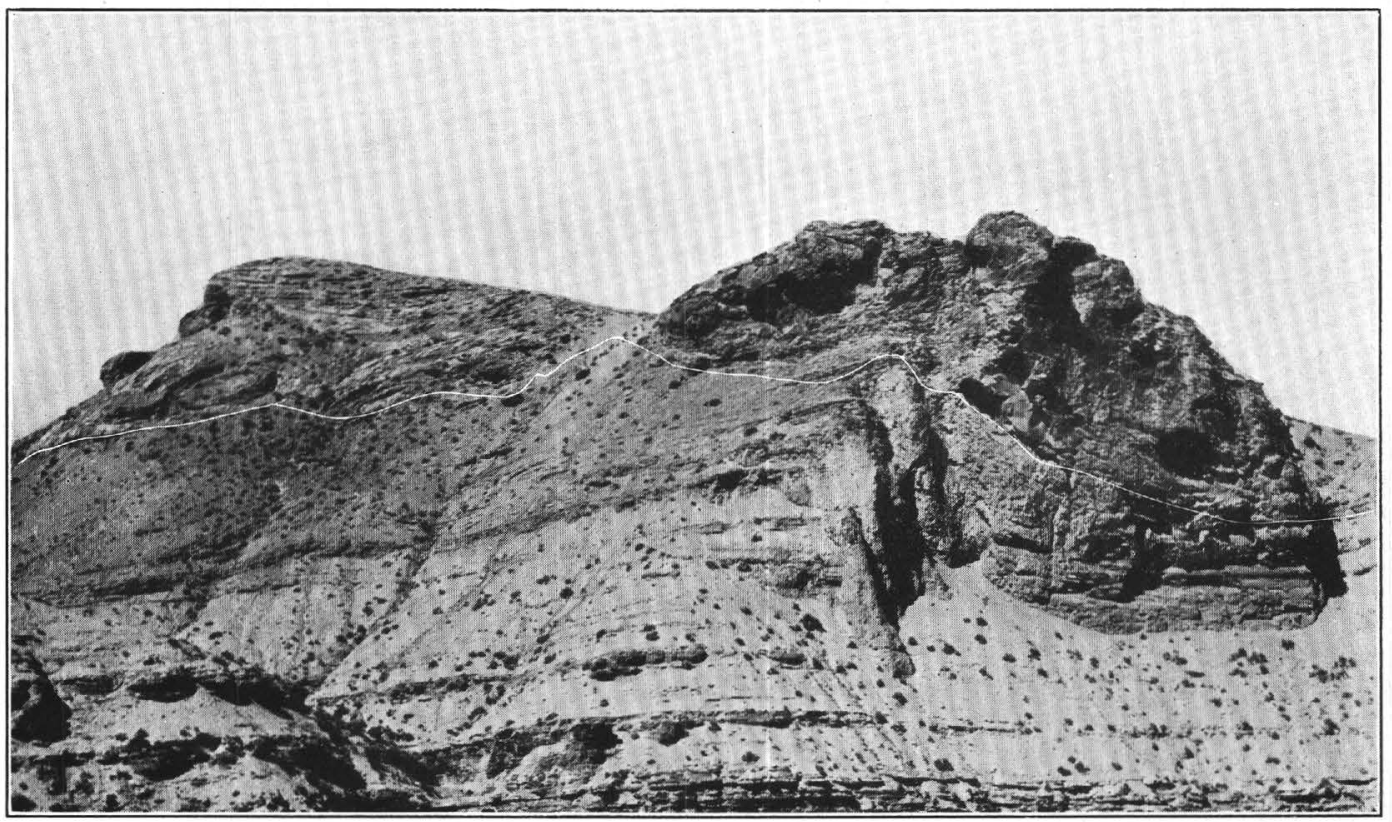

A. CONTACT BETWEEN THE BRIDGER AND GREEN RIVER FORMATIONS IN THE VALLEY OF EVACUATION CREEK, SEC. 12, T. 10 S., R. 24 E. SALT LAKE MERIDIAN, UINTAH COUNTY, UTAH

This view shows plainly the differential compaction between the shaly marlstone of the Green River formation (below white line) and the channel sandstone lenses at the base of the Bridger formation (above white line).

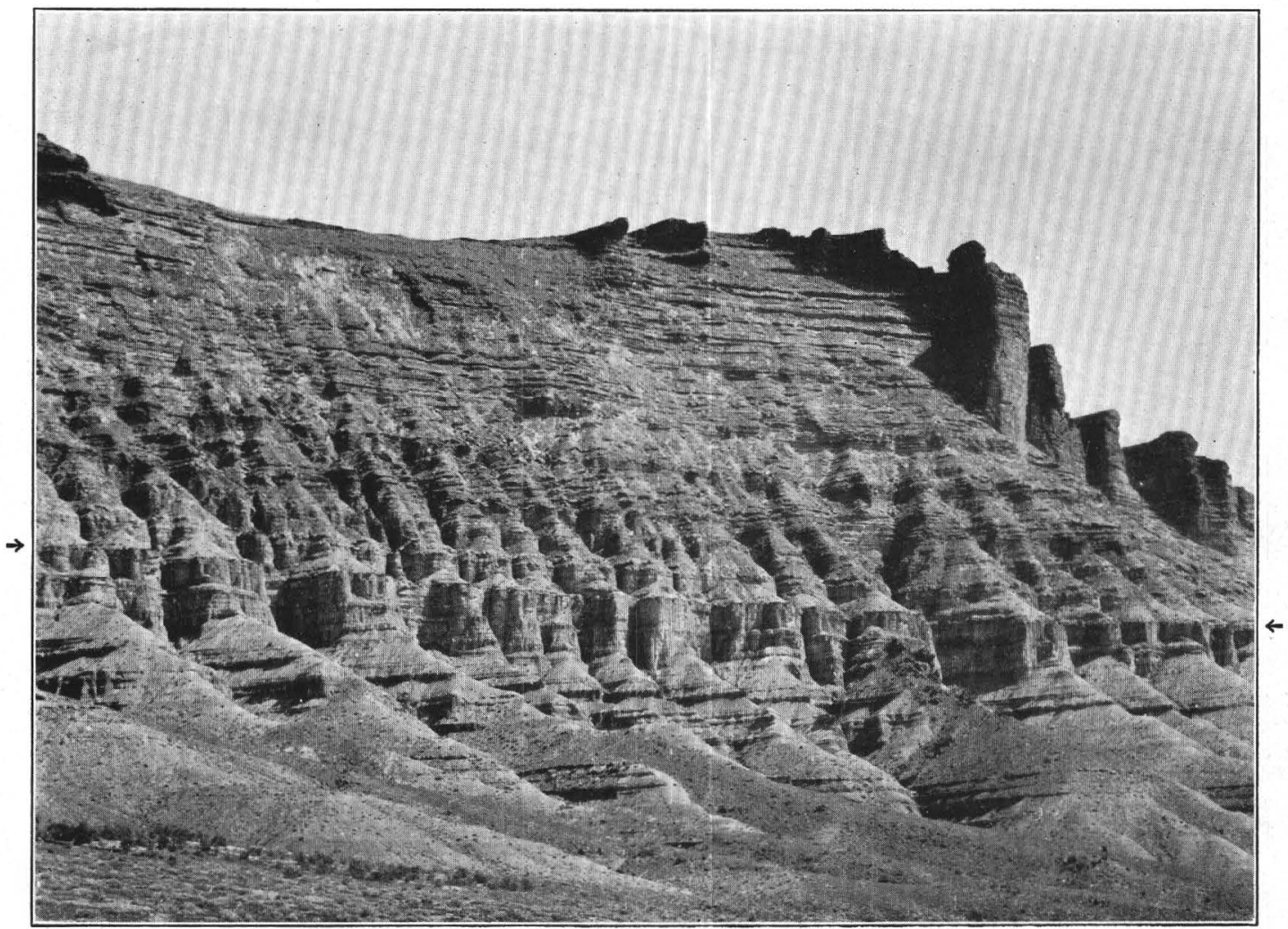

B. LOWER SANDY PART OF THE BRIDGER FORMATION RESTING IN EVIDENT CONFORMITY ON THE GREEN RIVER FORMATION, APPROXIMATELY IN SEC. 21, T. 11 S., R. 17 E., DUCHESNE COUNTY, UTAH The arrows at the margins mark the boundary. 
Most of them are thin bedded, dense, and buff or light chocolate-brown. Some beds contain an abundance of biotite.

Sandstone is even less abundant than limestone and makes up less than 3 per cent of this facies. Most of the beds are fine grained, muddy, micaceous, and platy. A very few are coarse grained and massive. Many of them are mud cracked, and some contain mud curls or plant fragments.

A thin bed near the base of the oil-shale zone, about 2,900 feet above the base of the formation, is saturated with bitumen but proved upon microscopic examination to be an andesitic tuff. It consists largely of fresh crystals of augite, andesine feldspar $\left(\mathrm{An}_{40} \mathrm{Ab}_{60}\right)$, and biotite, together with small irregular fragments of brownish glass whose index of refraction is about 1.49. Some of these fragments of acidic glass contain aggregates of pyroxene and plagioclase feldspar, evidently fragments of a glassy lava. In addition to these major constituents, there are a few minute crystals of zircon and apatite. The secondary minerals are opal, which forms the groundmass of the rock, and calcite, which is coarsely crystalline and rare.

About 550 feet above the oil-shale facies is a group of sandstone beds about 16 feet thick which makes a conspicuous and very persistent bench. These beds are gray or brown, fine grained, and micaceous. Many are current-ripple bedded; some are massive and others platy. This persistent sandstone unit may be the westward extension of the Horse Bench sandstone, which it resembles. It is also at approximately the same stratigraphic horizon, 500 to 550 feet above the principal oil-shale beds.

There are only two thin algae reefs in the barren and saline facies. These are just below the saline zone.

Columnar section.-Plate 11 shows a columnar section of the Green River formation measured in Indian Canyon. It is a composite section whose base is in sec. 27 , T. $11 \mathrm{~S}$., R. $8 \mathrm{~W}$. Uinta special meridian and the top is approximately in sec. $21, \mathrm{~T}$. 4 S., R. $5 \mathrm{~W}$. A Brunton compass was used to measure the section. The beds were correlated by tracing out distinctive beds or groups of beds from one locality to another. Although none of the groups of beds of this composite section are widely separated, the base and top are about 26 miles apart. The section is therefore not a true cross section of the formation at any one place, and some of the changes of lithology upward from the base may be due to the fact that the parts of the section represent different parts of the basin.

\section{CORRELATION OF FACIES AND ZONES IN UINTA AND PICEANCE CREEK BASINS}

The correlation of the various facies and zones of the Green River formation in the Uinta Basin west of
Bitter Creek is shown diagrammatically in Plate 3. The basal facies, which in the vicinity of Indian Canyon is a lacustrine tongue, has been traced from Soldier Summit to the eastern part of T. 12 S., R. 13 E., where it crosses Ninemile Creek. Although it has never been traced from that point across the south margin of the basin, it is probably, from its similarity in lithology and stratigraphic position, exactly correlative with the basal unit along the White River near Watson. The second lacustrine facies, which includes a few beds of oil shale, has been traced from Narrows, in T. 9 S., R. 5 E., where it crosses the main line of the Denver \& Rio Grande Western Railroad, to T. 12 S., R. 13 E. Between Willow Creek and T. 12.S., R. 13 E., the tongue of the Wasatch formation dies out and the second lacustrine facies becomes a part of the basal unit of the Gate Canyon section. Although notably different, the delta facies of the Indian Canyon section is equivalent to that at Gate Canyon and that in the vicinity of the Duchesne-Uintah county line. Probably the delta facies near the Duchesne-Uintah county line is represented in the section along the White River north of Watson by the Garden Gulch member and the lower oil-shale group and overlying transitional beds of the Parachute Creek member. Winchestèr ${ }^{43}$ mapped the group of richest oil-shale beds and demonstrated that it is continuous from the head of the Strawberry River, in T. 8 S., R. 6 E., eastward along the south rim of the Uinta Basin to the Colorado line. (See pl. 1.) The group of richest oil-shale beds of Colorado is almost surely an eastward extension of that in Utah.

\section{BRIDGER FORMATION}

In the Piceance Creek Basin, Colorado, no formation younger than the Green River formation has been certainly identified, although the writer believes that the uppermost 400 feet of sandy beds in the center of the basin are lithologically and stratigraphically equivalent to the Bridger formation, and he has tentatively assigned them to that formation. No fossils have yet been found in these beds. Both the Bridger and Uinta formations have been defined by vertebrate fossils in Utah.

\section{LOWER BEDS}

In the eastern part of the Uinta Basin a thick series of brown massive or cross-bedded medium to coarse grained sandstone beds overlies the Green River formation. It forms a rough and rather steep southwardfacing slope interrupted by many benches of harder sandstone. (See pl. 12, B.) This unit is about 800 feet thick, contains a small amount of hard greenishgray sandy mudstone interbedded with the sandstone, and in most places rests with evident conformity on the Green River formation. In an area extending over

43 Winchester, D. E., Oil shale of the Rocky Mountain region: U. S. Geol. Survey Bull. 729 , p. 105, pl. 16, 1923. 
many square miles in the vicinity of Evacuation Creek and the White River north of Watson, Utah, however, the contact between the two formations is decidedly irregular, having locally a relief of as much as 50 feet. (See pl. 12, A.) This irregular contact does not appear to indicate an erosional unconformity but seems rather to have been due to differential compaction of the shaly marlstone beds at the top of the Green River formation and the sandy mudstone beds and streamchannel sandstone lenses at the base of the Bridger formation. The regular thin beds of marlstone at the top of the Green River formation have been flexed so as to conform to the lower surfaces of the thick sandstone lenses, and though they have been distinctly squeezed and thinned below the lowermost salients of
Bridger beds were uniformly distributed, the contact is regular. (See pl. 12, B.) But in those areas where the lowest beds of the Bridger formation contain large stringers and lentils of medium to coarse grained sandstone the contact with the underlying Green River formation is irregular. Apparently in these areas the first deposits in the Bridger epoch consisted of sandy mud, and these beds were trenched rather deeply by streams, which later filled their own channels with relatively clean medium to coarse grained and crossbedded sand. Locally these streams cut down close to the top of the Green River formation. After the stream channels were filled with sand a thick group of rather regular beds of muddy sand were laid down, and above them the remainder of the Bridger formation

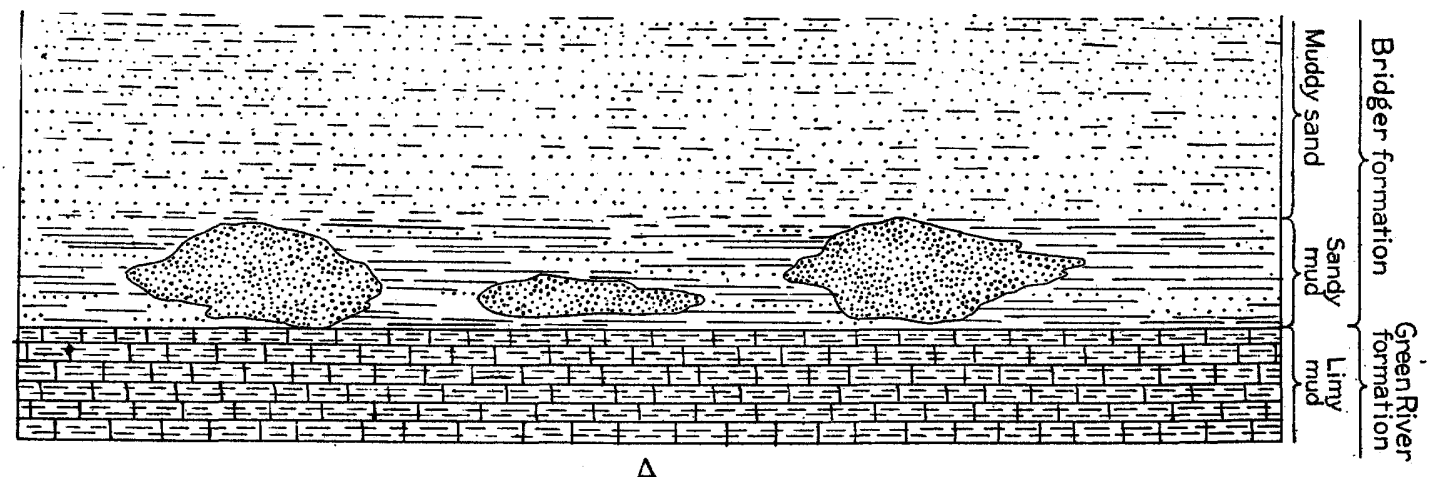

A

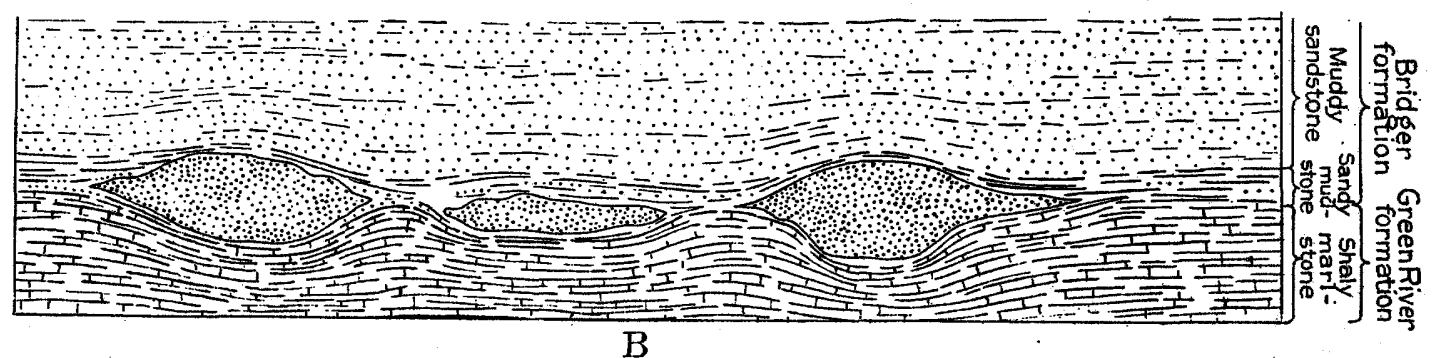

0

$\mathrm{B}$

300 FEET

FIGURE 2.-Probable original relation (A) between the beds of limy mud at the top of the Green River formation and the thick channel-sandstone lenses near the base of the Bridger formation near the mouth of Evacuation Creek, in sec. 12, T, $10 \mathrm{~S}$., R. $24 \mathrm{E}$. Salt Lake meridian, Uintah County, Utah, and the present relation between them (B) after having been compacted under the weight of nearly 2,000 feet of muddy sandstone and mudstone of the Bridger and Uinta formaticns

the sandstone lenses few of them have been truncated. Moreover, the beds of marlstone were deformed less and less downward, and a short distance below the sandstone lenses they were not at all disturbed. (See pl. $12, A$.) In the same way but to a less marked degree the beds of muddy sandstone overlying the sandstone lenses have been deformed, being compacted more over the highest parts of the lenses and less over the intervals between them. Likewise the sandy shale surrounding the sandstone lenses was much compacted above and below the sandstone lenses and less so between them.

The irregularity of the contact between the Green River and Bridger formations in certain localities, then, appears to be correlated with an irregular distribution of sandstone near the base of the Bridger formation. Where the sand and mud making up the lowermost and the Uinta formation. These overlying beds aggregate nearly 2,000 feet in thickness. Under this load the sediments at the top of the Green River formation and at the base of the Bridger formation were compacted. (See fig. 2.) Because the uppermost beds of the Green River formation and the sandy mud between the channel fillings were very fine grained they were distorted most by the relatively incompactible sand lentils. The beds of muddy sandstone that lie above the sand lentils were much less compactible than the fine-grained beds and accordingly were much less deformed.

For clarity the diagram shown in Figure 2 is considerably simplified. Actually in most places the sandstone lentils occur at various levels above the contact, overlap one another, and interfinger with the 
sandy shale, so that not only have the beds of marlstone and sandy shale been complexly contorted, but the thin fingers and marginal extensions of the sandstone lentils were considerably deformed and the crossbedding of the sandstone was twisted and tilted locally $15^{\circ}$ to $20^{\circ}$ from its original attitude. Because of this distortion of the cross-bedding it has been impossible to make out any regional trend in the dips of the cross beds and so determine the probable direction in which these early Bridger streams flowed-a determination that Rubey and Bass ${ }^{44}$ were able to make with certain stream-channel deposits of the Dakota sandstone in Kansas.

Winchester ${ }^{45}$ found fossil insects similar to those of the Green River formation in a thin mudstone bed of this large sandy unit and therefore included it in the Green River formation. Osborn ${ }^{46}$ and Peterson, however, regard this series of sandstone beds as a part of the Bridger formation, having found bones of Bridger mammals in it. The lower part of this sandstone unit, about 500 feet in thickness, contains few fossils, but according to Peterson ${ }^{47}$ the type specimens of Metarhinus and Sphenocoelus were found near the base. The upper part is more fossiliferous and according to Riggs ${ }^{48}$ contains Metarhinus, Dolichorhinus, Telmatherium, Mesatirhinus superior, Rhadinorhinus, Eobasileus, Triplopus, Mesonyx, and Harpagolestes, all of which are Bridger fossils. A few crocodiles, many turtles, and beds of fresh-water clams were also found. Reeds, leaves, and branches of trees were associated with the vertebrate fossils.

Because this sandstone series contains vertebrate fossils of Bridger age and because the very distinct lithologic change from regularly laminated marlstone and shale to medium-grained massive or cross-bedded sandstone indicates an abrupt change from lacustrine to fluviatile conditions, the writer prefers to regard it as a part of the Bridger formation, in spite of the fossil insects which it contains. Moreover, the insects are so like those now living that it seems dubious if they could be used to date so small a stratigraphic interval and to controvert the evidence of so large a vertebrate fauna.

It is somewhat puzzling that the vertebrate fossils found near the base of the sandstone series indicate middle or late Bridger time. This suggests that, as there appears to have been no significant break in sedimentation between the Green River and Bridger formations, the uppermost portion of the Green River formation is perhaps of Bridger age. In other words,

44 Rubey, W. W., and Bass, N. W., The geology of Russell County, Kans.: Kansas Geol. Survey Bull. 10, pp. 54-62, 1925.

45 Oral communication, September, 1925.

t6 Osborn, H. F., Fossil mammals of the Uinta beds: Am. Mus. Nat. History Bull., vol. 7, p. 73, 1895.

47 Peterson, O. A., quoted by Riggs, E. S., New or little-known tițanotheres from the lower Uinta formations: Field Mus. Nat. History Pub. 159, Geol. ser., vol. 4, p. 23, 1912.

48 Idem, p. 24 if the boundary between the Green River and Bridger formations were to be determined wholly by the vertebrate fossils it apparently should be placed at some indefinite horizon below the present lithologic boundary. According to this definition of the boundary, lakes seem to have persisted longer in the Uinta Basin than in the Green River Basin of Wyoming, where all of the Bridger epoch is represented by fluviatile deposits.

The writer has traced the contact between the Bridger and Green River formations a ong the north side of the White River from a place near the Colorado line southwestward to the mouth of Evacuation Creek, where the contact crosses the river, and westward across Uinta Basin to the Green River. It crosses the Green River near the northeast corner of T. 11 S., R. 18 E. Salt Lake meridian. Thence westward to the head of Gate Canyon it is nearly parallel to the road from the head of Gate Canyon to Hill Creek. West of Gate Canyon it has not been traced, and in Indian Canyon the contact between the two formations is transitional and uncertain.

The lower part of the Bridger formation is variable along the strike, and in places the lithologic changes are rather abrupt. In sec. 22 , T. 11 S., R. 17 E. Salt Lake meridian, it consists almost wholly of fine-grained brown micaceous sandstone in fairly regular beds, most of which are massive but some of which are cross-bedded or ripple bedded. The ripple bedding consists of only the steeper foreset beds, which dip generally northwest. Near the base are a few thin zones of hard gray sandy mudstone that have thin and regular bedding. One such zone contains a thin bed of carbonaceous shale. Near the top are several more beds of hard greenish-gray sandy mudstone. At this place the unit makes a steep cliff, which was measured by triangulation and found to be 454 feet high at one point and 495 feet at another. (See pl. 12, B.)

A few miles west, about in sec. 10, T. 11 S., R. 16 E., the Bridger formation contains only a little sandstone and makes a rather gentle slope that is faintly color bended. It consists mostly of buff and light-gray sandy mudstone. At the head of Gate Canyon the lower third of the unit consists of brown irregular sandstone with a smaller amount of gray sandy mudstone, and the rest consists of mudstone with a subordinate amount of sandstone.

In Indian Canyon the writer measured a detailed section of the lower part of the Bridger formation. It is about 550 feet thick. A little less than half of it is sandstone, most of which is medium grained, muddy, dark brown, and crudely platy. The beds are ripple bedded and discontinuous and alternate with sandy mudstone and shale. Locally this part contains thick massive lenses of yellowish-brown sandstone. The rest of the section consists of coarsely flaky sandy and limy shale and several beds of hard marlstone. Some 
of the shale is lavender, and some is distinctly reddish. Many beds contain small mud flakes and curls; a few are carbonaceous and mottled red and pale green.

\section{UPPER BEDS}

The upper part of the Bridger formation, zone B of Osborn ${ }^{49}$ and Peterson and the "Amynodon beds" of Riggs, ${ }^{50}$ consists of greenish, drab, red, maroon, ashgray, and buff sandy mudstone with lenticular medium to coarse grained massive or cross-bedded muddy sandstone beds, many of which are ferruginous and dark brown. Some are greenish brown and somewhat shaly. The writer observed this part of the formation at several places in the Uinta Basin, but did not study it.

The Uinta formation overlies the Bridger with apparent conformity.

\section{RELATIONS OF THE TERTIARY FORMATIONS IN THE UINTA} BASIN

The major relations of the Bridger and Uinta formations to the other Tertiary formations are not wholly clear. At the southern outcrop of the Bridger and Uinta there is no angular discordance between them or between the Bridger and Green River, and yet on the north side of the basin in the vicinity of Vernal the Uinta formation rests with marked angular unconformity upon the Mesaverde formation. Either of two explanations accords with these observations.

One explanation is based on the hypothesis that the Cretaceous rocks (the Mesaverde formation) were already flexed so as to form a basin whose north rim turned up rather steeply along the flanks of the Uinta Mountains. In that basin the Tertiary, Wasatch, Green River, Bridger, and Uinta formations were all deposited in strict conformity with one another. Accordingly each successive Tertiary formation would overlap more and more upon the edges of the rather steeply inclined Mesaverde formation along the north rim of the Uinta Basin. Around the other parts of the basin rim the initial inclination of the Cretaceous rocks was presumably so gentle that there is now no discernible discordance between them and the overlying Wasatch formation.

The other explanation also postulates a similar original basin of Cretaceous rocks but one whose northern rim was less steeply upturned. This hypothesis differs chiefly from the first, however, in assuming an angular unconformity either between the Green River and Bridger formations or between the Bridger and Uinta formations. The writer has found no evidence that leads him to regard as probable an unconformity between the Wasatch and Green River

\footnotetext{
1 Osborn, H. F., Fossil mammals of the Uinta beds: Am. Mus. Nat. History Bull., vol. 7, p. 74, 1895.

${ }^{50}$ Riggs, E. S., New or little known titanotheres from the lower Uinte formations: Field Mus. Nat. History Pub. 159, Geol. ser., vol. 4, p. 22, 1912.
}

formations, although Eldridge ${ }^{51}$ bas explained this same overlap of the Uinta formation on the Cretaceous rocks along the north margin of the Uinta Basin by that assumption. The very abrupt change in lithology between the Green River and Bridger formations makes a diastrophic break there much more probable than one between the Bridger and Uinta formations, whose rocks are so nearly identical that the boundary between them can be determined only by the vertebrate fossils. According to this second hypothesis the Wasatch and Green River formations might rest with only a slight angular discordance upon the Cretaceous rocks, but the Bridger formation would truncate the Green River and Wasatch formations and overlap the Mesaverde. The Uinta would then overlap the Mesaverde still more, producing the relations observed in the vicinity of Vernal, Utah. Further speculation is unwarranted without more field study in the area extending from the place where the White River enters the Green River formation west of Rangley, Colo., along Raven Ridge to the asphalt quarry about 3 miles southwest of Vernal, Utah.

\section{THE OIL SHALE}

\section{DEFINITION}

The term."oil shale" is defined on page 7 , where it is also pointed out that most of the oil shale of the Green River formation could not be regarded strictly as shale, but instead that it is really a more or less magnesian marlstone rich in organic matter.

\section{APPEARANCE IN HAND SPECIMENS}

The organic matter in oil shales imparts to them a distinctive aspect, which, however, varies greatly in different shales, depending chiefly upon the amount of organic matter and its distribution in the rock. To some extent also the appearance of these organic rocks, particularly the lower grades of oil shale, is determined by their predominant inorganic constituents. Rocks consisting largely of clastic mineral grains of clay size with which is admixed only a small quantity of organic matter resemble ordinary barren shale or mudstone except for a faint brownish tone on the fresh fractures. Such beds are particularly common in the shore phases of the formation and range in potential oil yield from 2 or 3 to as much as 10 or 12 gallons to the ton. Beds of ostracode-bearing limestone and ostracode-bearing shale, also in shore phases of the formation, are colored buff, yellowish brown, or even dark chocolate-brown with the organic matter that is uniformly diffused through them. They will yield oil in quantities ranging from 5 or 6 to perhaps 20 gallons to the ton. Dense marlstone, which ranges in color from light brownish gray or buff to chocolate-brown on fresh surfaces, is

51 Eldridge, G. H., The asphalt and bituminous rock deposits of the United States: U. S. Geol. Survey Twenty-second Ann. Rept., pt. 1, p. 338, fig. 29, 1901. 
very common, especially in the central parts of the basins. In rock of this type the organic matter may be uniformly diffused, imparting a light-brown or dark grayish-brown color, or it may be segregated in fine dark-brown laminae. As these three distinct types of low-grade oil shale weather buff, yellowish brown, or greenish gray, they can only with difficulty be distinguished from beds wholly barren of organic matter.

All transitions exist between these low-grade types, which themselves are intergradational, and the highgrade oil shale, which in general has a more uniform aspect both on fresh and weathered surfaces. Highgrade oil shale, which may be regarded as that capable of yielding more than about 10 gallons of oil to the ton, ranges in color from grayish brown, which may have a faint yellowish or reddish cast, to jet black. In most beds brown laminae are intermingled with darker-brown or black laminae which have a satiny luster. However, some beds are apparently homogeneous. These are either of a dull, lusterless black or jetlike with a bigh luster. Both of these varieties are very rich in organic matter and represent the highestgrade oil shale of the Green River formation. They grind down to a light grayish-brown, somewhat waxy powder. They resemble rather closely the purer varieties of algal bogheads, such as the kerosene shale of New South Wales or the Bathgate boghead of Scotland.

Weathered surfaces of rich oil-shale beds are distinctive and easily distinguished from other beds. Most of them weather light bluish gray, a color which is apparently due to a very thin residual layer of the mineral constituents of the rock from which the organic matter has been oxidized. The dark organic matter showing through this thin film lends it the bluish tint. If the weathered film is thick it appears stark white. All transitions exist between this white weathered surface through shades of grayish blue and grayish lavender to black surfaces which have only a fine dusting of white or yellowish brown. Some of the richest beds weather to look like antique unfinished mahogany. Polished surfaces of shale of that kind, even when examined critically with a hand lens, simulate old mahogany in a remarkable manner. From this resemblance the group of richest oil-shale beds in the Green River formation known as the "mahogany ledge" takes its name.

There are a few aberrant types of rich oil shale which might easily be ignored in the field on the assumption . that they were nearly barren shale. The most unusual of these looks like a felted mass of coarse brown-paper pulp. It weathers silvery gray and has a distinctly talcose appearance. Almost the only mineral constituent of this rock is a fibrous variety of sepiolite. Somewhat similar but more papery beds look equally poor. They are finely speckled with white. Still others consist of alternating coarse laminae of brown shale and vitreous black scabrous organic material.

\section{OCCURRETCE}

The oil shale of the Green River formation is most abundant in the vicinity of Parachute and Roan Creeks, Colo., and gradually decreases in amount in all directions from that area toward the original margins of the ancient lake basin.

For the lake which occupied the Uinta and Piceance Creek Basins during the Green River epoch and in which the sediments were deposited that now make up the Green River formation of Utah and Colorado the writer has proposed the name "Uinta Lake." ${ }^{2}$ For the ancient contemporary lake that occupied the Green River Basin north of the Uinta Mountains the writer has used the name "Gosiute Lake," 53 which King ${ }^{54}$ suggested long ago. Northward beyond the White River the beds of oil shale rapidly thin and become poorer in quality until in the area north of Deep Channel Creek none of the beds contain more than a minute quantity of organic matter. This relation between oil shale and shore phases of the Green River formation is typical and, as the writer has shown, ${ }^{55}$ is well illustrated in several parts of the Green River Basin of Wyoming.

The oil-shale units extend more than 140 miles westward from the vicinity of Parachute and Roan Creeks but thin gradually in that direction and become progressively less rich as they approach the western margin of the lake basin. In the Uinta Basin the changes in the oil shale from south to north can not be observed, for the beds do not crop out along the north margin of the basin but are buried beneath an overlap of younger rocks.

The vertical distribution of the oil shale in the Green River formation of Colorado and Utah is indicated in a broad way in Plate 3 . It is shown in much more detail for several localities in the columnar sections of Plates 7, 8, and 11 . In these columnar sections the estimated yields of many of the beds are given, but it should be noted that these estimates are subject to rather large errors, and therefore the columnar sections are chiefly of use in showing the number and distribution of the richest beds. Many beds indicated in the sections as organic marlstone or simply marlstone will yield oil upon distillation in amounts ranging from 2 or 3 gallons to as much as 10 or 12 gallons a ton. In general the richest of these beds of low-grade oil shale or organic marlstone are associated with beds of rich oil shale.

A more accurate picture of the relative richness of the beds in the principal oil-shale zones is given in

Bradley, W. H., The varves and climate of the Green River epoch: U. S. Geol. Survey Prof. Paper 158, p. 88, 1929.

ss Idem, p. 88.

4 King, Clarence, U. S. Geol. Expl, 40th Par, Rept, vol, 1, p. 446, 1878.

5s Sears, J. D., and Bradley, W. H., Relations of the Wasatch and Green River formations in northwestern Colorado and southern Wyoming: U.S. Geol. Survey Prof. Paper 132, p. 101, 1924. Bradley, W. H., Shore phases of the Green River formation in northern Sweetwater County, Wyo.: U. s. Geol. Survey Prof. Paper 140 , p. $127,1926$. 
ORIGIN AND MICROFOSSILS OF OIL SHALE OF GREEN RIVER FORMATION

Plate 13, which shows the results of several long series of retort tests. These series of retort tests, designated $\mathrm{A}, \mathrm{B}$, and $\mathrm{C}$ in Plate 13 , can be correlated with the columnar sections shown in Plates 7 and 8 by means of the mahogany marker, which was used as a datum for the retort tests and whose position is indicated in the columnar sections of Plates 7 and 8 . Of these series of retort tests the series designated A in Plate 13 was the longest and the one that showed the greatest differentiation of the beds. This series of tests was submitted to the Department of the Interior at a hearing on oil shale held before the Secretary December 1, 1926.

Additional information as to the correlation of the groups of beds sampled was given to the Geological Survey by Mr. Flavius Wood, ${ }^{56}$ who was the engineer in charge of the sampling and testing of the group of beds in this section extending from the base to a level 328 feet above the mahogany marker. The samples were collected on Clear Creek in sec. 9, T. 5 S., R. 98 W., Garfield County, Colo., and the retort tests were made in standard test retorts according to the Bureau of Mines specifications ${ }^{57}$ at the American Shale Oil Co.'s camp. The oil yields from about half the samples were checked by duplicate tests. The uppermost group of beds in section A were collected on the West Fork of Parachute Creek in secs. 2 and 3, T. 5 S., R. 97 W., Garfield County, Colo., and tested by J. W. Richards \& Son, of Denver, for the Federal Oil Shale Co. Several thin beds in the lower part of section A all have decidedly lower potential oil yields than the adjacent beds. These occur at $8,26,56,101 \frac{11}{2}$, and $103 \frac{1}{2}$ feet below the mahogany marker and, like the mahogany marker, are probably beds of altered volcanic ash. It is probable that they too have great lateral extent and could be used as horizon markers.

The series of retort tests designated $B$ in Plate 13 was furnished by the Columbia Shale Oil Co. It was nearly as long and showed almost as much differentiation of the beds as series A. The samples for this series were collected by Mr. F. A. Goodale and two assistants on the East Middle Fork of Parachute Creek in sec. 16, T. 5 S., R. 95 W., Garfield County, Colo. The oil yields were determined in standard test retorts at the Columbia Shale Oil Co.'s camp, in sec. 16, by Mr. Goodale and his assistants.

The series of tests designated $\mathrm{C}$ in Plate 13 was furnished by the Ute Oil Co. The samples were collected in the canyon of the White River in sec. $5, T .10 \mathrm{~S} ., \mathrm{R}$. 25 E. Salt Lake meridian, Uintah County, Utah, by Mr. Thomas J. Davis and his assistants. The tests were made in small test retorts comparable to those recommended by the United States Bureau of Mines at the Ute Oil Co.'s camp in sec. 5, T. 9 S., R. 25 E. This

${ }^{56}$ Personal communication, Dec. 18, 1927.

" Karrick, L. C., Manual of testing methods for oil shale and shale oil: U. S. Bur. Mines Bull. 249, pp. 2-28, 1926. series of tests was considerably shorter than the others, and the samples tested represented groups of beds rather than individual beds as in the other two series. Nevertheless it affords an interesting comparison of the oil-shale beds in the extreme eastern part of the Uinta Basin with those in the deepest part of the Piceance Creek Basin, represented by series $A$ and $B$.

\section{SEDIMENTARY STRUCTURE IN THE OIL SHALE AND ASSOCIATED ROCKS}

MAJOR FEATURES OF BEDDING

REGULAR BEDS AND THETR STGNIFTCANCE

In general the bedding of the oil-shale groups is thin and regular. Bed follows bed with monotonous uniformity through series measured in hundreds of feet. Slight differences in texture, relief, and color tone serve to distinguish the beds. Planes that appear to be geometrically perfect separate them. Such sharply defined beds range in thickness from a few inches to about 29 feet and represent units of sedimentation separated from one another by apparently abrupt changes in conditions. These abrupt changes may have been caused by breaks in sedimentation or merely by quick changes in the kinds of material deposited. The sharp change from dense marlstone which is banded with more or less regularly spaced fine laminae colored brown by organic matter to rich oil shale indicates a marked change in the conditions of deposition.

The leaner beds of dense marlstone with their minute, sharply defined varves, which average about 0.15 millimeter in thickness, must have been deposited in very quiet water. Otherwise the organic matter, which was an ooze at the time of deposition would have been stirred up and scattered through the deposit, giving it a nearly homogeneous and lighter-brown color. Probably these varved beds accumulated in water so deep that waves and ordinary currents had practically no effect upon them. At rare intervals small groups of varves in these beds have evidently been disturbed, for the lamination has been almost wholly effaced and organic matter is diffused through zones a fow millimeters thick. Apparently much of the rich oil shale also accumulated in relatively deep water, for it has an analogous laminate structure, but on the other hand many beds seem as clearly to have accumulated in shallow water at stages when the area of the lake was considerably reduced. The evidence upon which this conclusion is based is summarized on pages 28-29.

Certain of these abrupt changes in lithology are rhythmic and appear to be related to cyclic changes of climate induced by the precession of the equinoxes. At a horizon roughly 150 feet above the "mahogany ledge" is a small group of beds of oil shale and organic marlstone that alternate in a regular manner. This group has been recognized at three localities in Garfield County, Colo.-near the head of the East Middle Fork of Parachute Creek, in sec. 16, T. 5 S., R. 95 W.; on the north 
side of Cathedral Creek, approximately in sec. 26, T. 3 S., R. 99 W.; and on Clear Creek in sec. 9, T. 5 S., R. $98 \mathrm{~W}$. Most of the beds of organic marlstone, which contain fly larviae in remarkable abundance, are about 6 feet thick, and the beds of oil shale average a little less than 2 feet thick. According to the rates of accumulation indicated by varves in rock of these two types each sedimentary cycle, which is represented by one oil-shale bed and one marlstone bed, has an average interval of $a$ little more than 21,600 years. ${ }^{58}$ The average interval of the precession cycle and the cycle of the change in eccentricity of the earth's orbit is about 21,000 years.

The significance of the other similar but nonrhythmic abrupt changes of lithology is obscure, but it seems likely that the dominant factors were climatic, for the differences between successive beds lie chiefly in the content of organic matter rather than in the mineralogy, and the rate of production of organic matter in lakes depends largely upon the temperature. Changes in rate of warping of the lake bottom and other like physical changes probably would have been too gradual to cause such abrupt changes in the sediments. But, whatever the causes, it seems necessary, in order to rccoun ior the abruptness of these changes, to assume that $a$ aditions favorable to the formation of one type of sediment, once established, were fairly stable until a certain critical point was reached, when they changed rather quickly to another set of conditions which were equally stable but which favored the formation of a somewhat different kind of sediment.

\section{LENTICULAR BEDS AND THEIR SIGNIFTCANCE}

Not all oil-shale beds in the Green River formation are so extensive or so regularly bedded as those just described. On the contrary, many are exceedingly irregular either in thickness or in structure, or both. A great many beds of oil shale, especially those not included in the two chief oil-shale units, are lenticular. Most of these lenses are intercalated between relatively thick units of low-grade oil shale. They vary greatly in size and proportions. The most plentiful are lenses of very rich oil shale from half an inch to about 3 inches thick in the center and from about 15 feet to about 300 feet long. These taper uniformly to very thin but well-defined edges. Some lenses of these proportions, however, appear to be merely local thickenings of very thin, filmlike layers of organic matter which can be discerned only with difficulty. Locally thicker beds finger out into beds of low-grade oil shale by splitting up into several long, thin wedges whose rate of taper is about equivalent to that just described for the individual thin lenses. Presumably such thin lenses of oil shale accumulated in residual pools in the lake bottom.

\footnotetext{
is Bradley, W. H., The varves and climate of the Green River epoch: U. S. Geol. Survey Prof. Paper 158, pp. 105-106, 1929.
}

At a few places, high in the formation, the writer found very short stubby lenses of rich oil shale that clearly had been deposited in small dishlike depressions. Some of these short lenses found about 2,300 feet above the base of the Parachute Creek section rest in irregular depressions in the upper surface of a low-grade oil-shale bed and are overlain by a bed of earthy and somewhat carbonaceous marl. Most of these lenses are less than 1 foot long and from 1 to 3 inches thick. All end abruptly, wedging out from the maximum thickness within 4 or 5 inches along the bed. These short stubby lenses seem to have accumulated in small isolated pools that filled the depressions which the lenses now occupy. Thus they appear to corroborate other evidence that at certain stages the ancient lake contracted greatly, so that large areas of the bottom were exposed to the air. It is difficult to imagine such small pools having existed over periods of time long enough for the production of so much organic matter unless the water table was practically coincident with the surface of the lake bottom, so that in effect these small disconnected pools were furnished with spring water at a rate about equal to the evaporation. Of course, the water level must have been subject to repeated changes from this assumed stable equilibrium. Some indication of these supposed changes is furnished by irregular, somewhat contorted limy layers within the oil shale, which the writer regards as deposits formed at stages of higher water and then later warped and distorted by drying out when exposed to the air:

In 1924 the writer found small isolated spring-fed pools similar to those just postulated on the terraces of Strawberry Creek in sec. 12, T. 2 N., R. 95 W., Rio Blanco County, Colo. These terraces consist of sandy clay derived chiefly from the Wasatch formation. The pools were fed at a rate apparently just balanced by the rate of evaporation, for they did not overflow. They contained a prodigious quantity of organic matter, chiefly blue-green algae. Decay was going on along with the rank growth of vegetable matter. The whole mass, which was about 6 inches deep, had the consistency of very thick soup and supported countless nematodes and a lesser number of small dipterous larvae. In 1925 the writer found similar though somewhat larger spring-fed pools that were nearly as thick with living and decomposing aquatic organisms in the valley of the Strawberry River in the eastern part of Wasatch County, Utah, and again on the broad mud flat on the west side of Little Salt Lake near Parowan, Utah.

The soft, earthy, and somewhat carbonaceous marl that immediately overlies the short stubby lenses of oil shale near the top of the Parachute Creek section of the Green River formation is interpreted as a deposit somewhat akin to material now accumulating in places along the margins and out on the mud flats of Abert Lake, in southern Oregon, and Little Salt Lake, in 
Utah, where there is a rather sparse stand of sedges. Such a deposit, therefore, is regarded as indicating a period of time following the oil-shale deposition when the lake bottom at that place was exposed to air.

\section{MINOR FEATURES OF STRATIFICATION} IAYMTATION

The distinction between bedding and lamination is one of size, and Twenhofel's suggestion ${ }^{59}$ that the term "laminae" be restricted to layers less than half an inch thick is followed in describing the sedimentary structure of the oil shale and related rocks of the Green River formation.

With a very few exceptions the beds of oil shale are thinly laminated. A few beds of fine-grained limy sandstone contain laminae near the maximum thickness, and some rich oil-shale beds have no discernible lamination. In a rough way, the greater the proportion of organic matter in the rock the thinner the laminae. Thus in some of the poorer grades of oil shale the laminae may be as much as 0.5 millimeter thick, but in the higher-grade shales they may be as thin as 0.014 millimeter. (See pl. 14,B.) In most beds, however, the laminae are grouped more or less regularly, so that in the hand specimen the lamination appears to be somewhat coarser than it really is.

The lamination is due to an alternation of layers rich and lean in organic matter. In some beds the lamination is rhythmic, but in others it seems to be unsystematic. The rhythmic laminae have been interpreted by the writer as varves, and as their origin and significance have been fully discussed in another report ${ }^{\circ 0}$ it will suffice here merely to summarize the conclusions drawn from that investigation. Each varve consists of two laminae, one of which is made up principally of carbonate and clay particles and the other chiefly of structureless organic matter. This bipartite structure of the varves is explained in part by the differential settling rates of the two groups of constituents and in part by assuming essentially continuous sedimentation of the mineral and organic constituents, with first a peak in the production of the carbonates and then a peak in that of the plankton. Both peaks apparently occurred in the summer. The varves differ considerably in thickness, according to the kind of rock in which they occur, ranging from a minimum of 0.014 millimeter in the beds of richest oil shale to about 9.8 millimeters in the beds of fine-grained sandstone.

The time value of the varves is tested by analogy with the varves in the deposits of certain modern lakes and also by calculating from data on present stream loads the thickness of annual laminae to be expected in the ancient Gosiute Lake. On the basis

59 Twenhofel, W. H., Treatise on sedimentation, p. 432, 1926.

Bradley, W. H., op. cit. (Prof. Paper 158), pp. 87-110. of tha varves the writer estimates that the Green River epoch lasted between $5,000,000$ and $8,000,000$ years.

Not all the thin laminae in the oil shale and related rocks are as regular and persistent as the varves. In some beds, particularly the richer oil-shale beds, the laminae are lenticular. The organic laminae range in length from about 1.5 to about 7.3 millimeters and in thickness from about 0.015 to about 0.075 millimeter. The lenses of mineral grains are a little thicker and range in length from about 0.5 to about 2 millimeters, but they are ill defined, and most of them terminate by an insensible gradation into the organic matter. Although they are characteristically thin, they appear, locally, to be transitional into larger, sharply defined concretionary lenses of mineral grains which range from about 0.25 to 20 or more millimeters in length and whose thickness is about one-fourth the length. This transition into distinct concretions suggests that the lenticular mineral laminae may owe their form to rather weak tendency for the mineral grains to aggregate into concretionary masses. Nevertheless it is equally reasonable to suppose that their form may be entirely original. They may be the mineral laminae of varves that were deposited in slight depressions in the organic ooze, or the mineral particles may have been assembled by feeble water currents at the time of deposition.

\section{OOKTORTED BEDDHA}

Contorted bedding is common in beda of the Green River formation above the basal zone. In general it is more common in high-grade oil shale than in low-grade oil shale, but locally beds of sandy shale, marlstone, and even finemgrained sandstone show it. In the section measured along Parachute Creek contorted bedding was found at 23 different horizons. At 20 of these the structure was in high-grade oil shale, at two it was in dense marlstone finely banded with laminae rich in organic matter, and at the other it was in a fine-grained limy sandstone.

The flexures in the rich oil shale range in complexity. from rather simple folds whose axial planes are considerably inclined from the vertical, through large overfolds upon which one or two sets of minor folds are imposed, to extremely intricate plications and long overthrusts whose thrust planes undulate. (See pl. 14, A.) Practically all the deformation in these beds occurred when the material was plastic enough to yield readily without fracturing and yet firm enough to retain its form after deformation. Only in a few places are the strata broken at rather obtuse angles to the bedding, and where parts of one bed overrode the lower parts the laminae are drawn out greatly along the gliding surface. Consequently the gliding surfaces are not sharply defined, because the material which is drawn out in to "schlieren" blends insensibly into other 


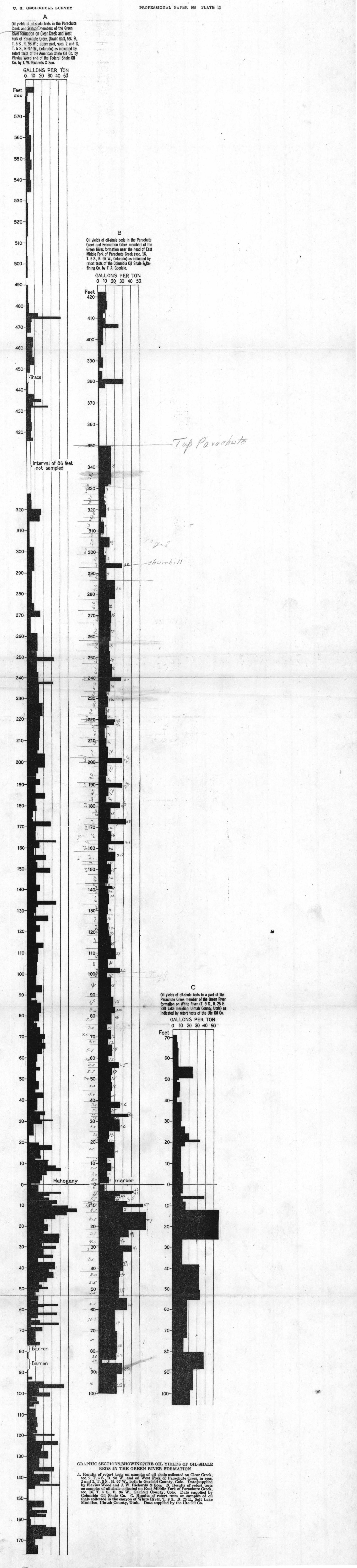




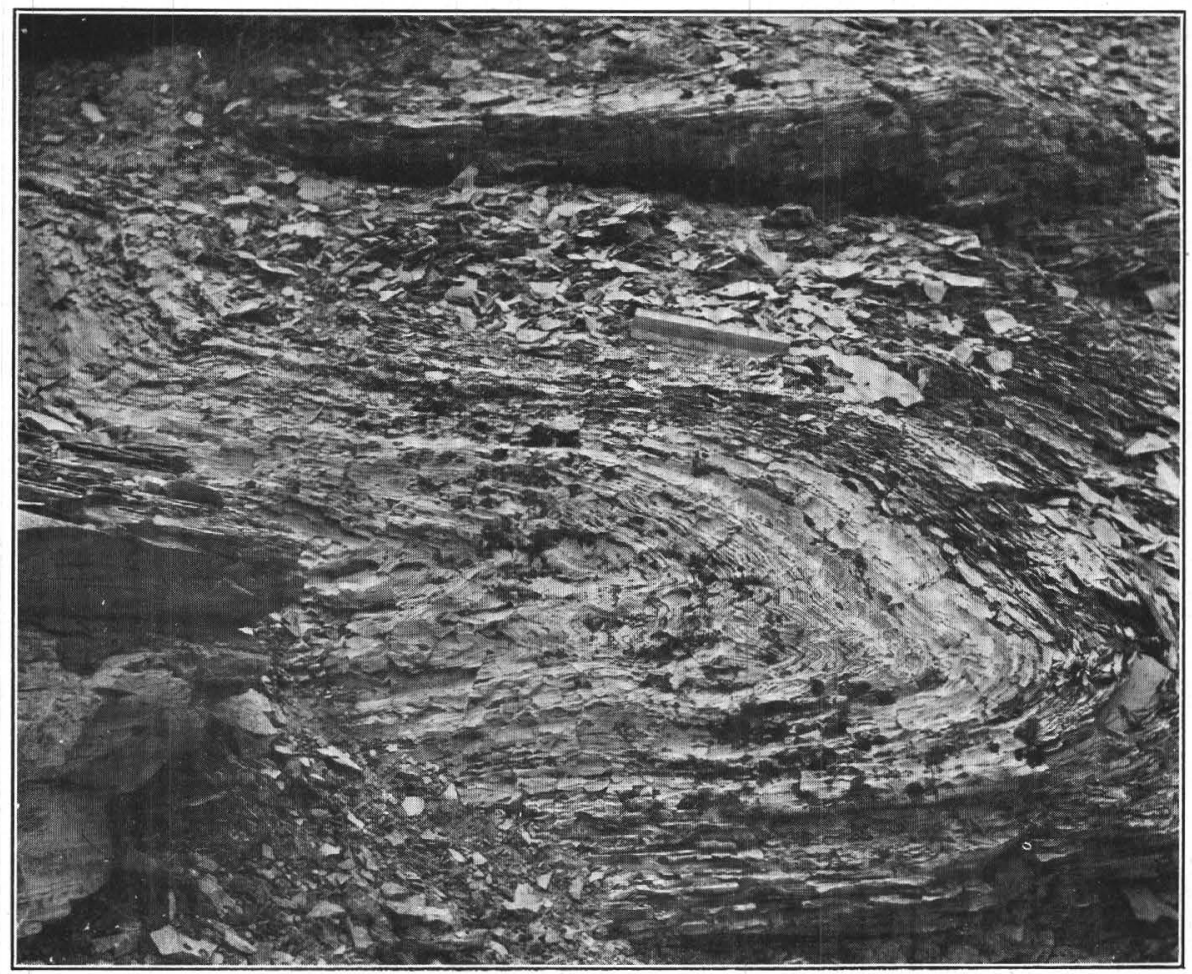

A. CONTORTED BEDDing DUE TO DIFFERENTIAL COMPACTION IN A BED OF OIL SHALE NEAR THE MOUTH OF PICEANCE CREEK, COLO.

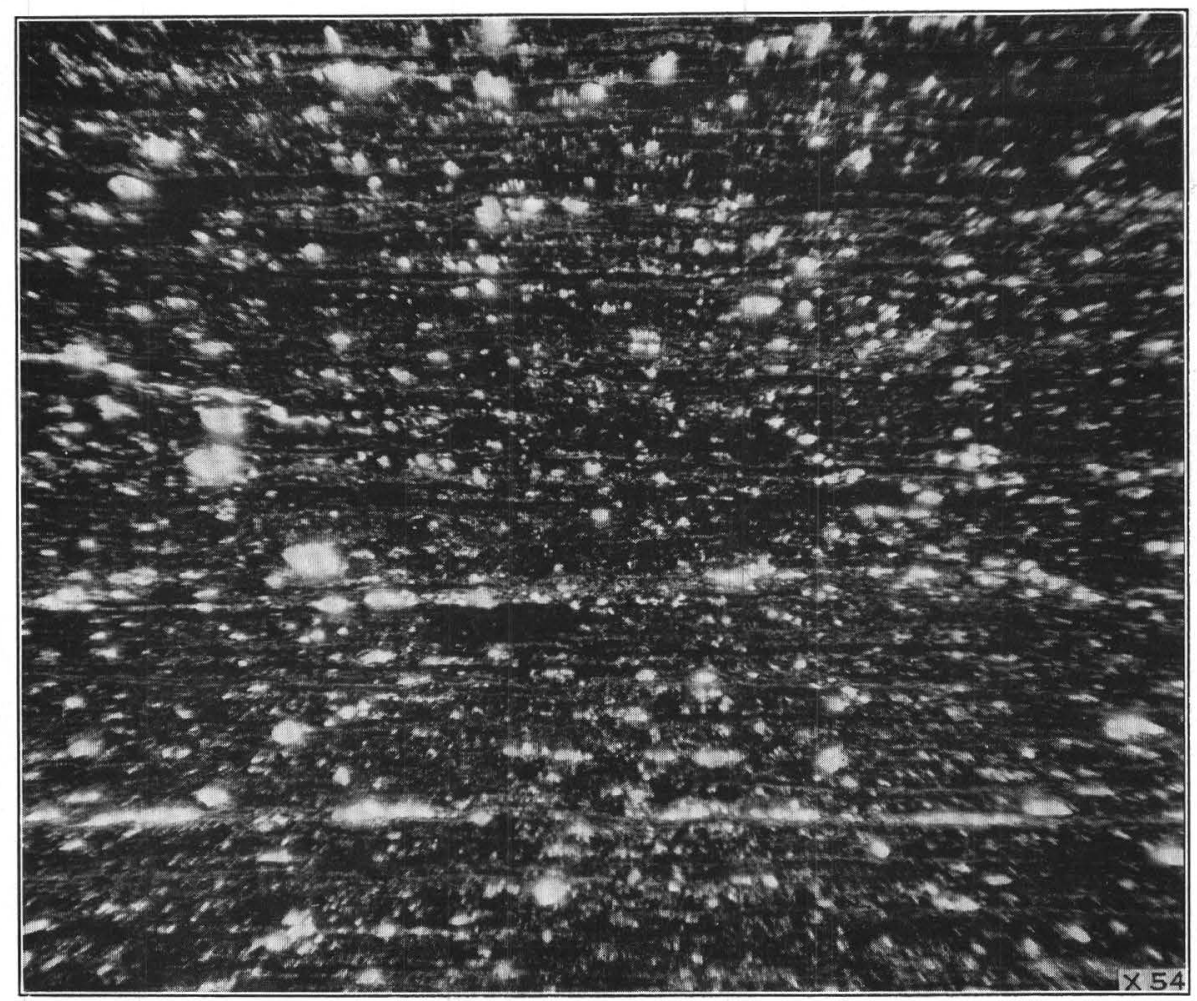

B. PHOTOMICROGRAPH OF A THIN SECTION OF RICH OLL SHALE FROM THE "MAHOGANY LEDGE" NEAR THE HEAD OF CLEAR CREEK, IN SEC. 9, T. 5 S., R. 98 W., GARFIELD COUNTY, COLO.

Shows thin regular lamination (varves). The black parts are organic matter, and the light-gray areas are mineral grains. 


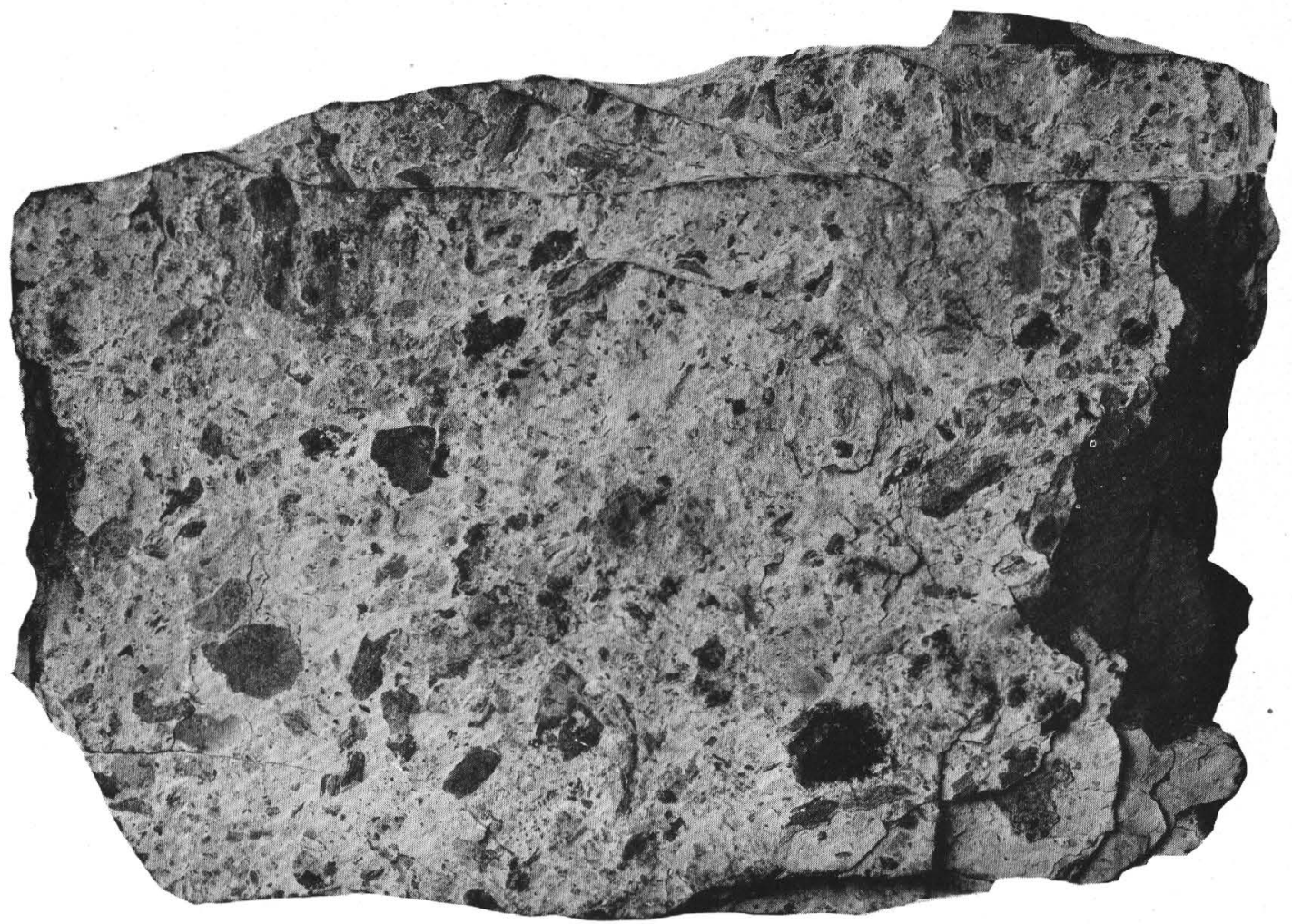

A. MOSAIC BRECCIA IN OIL SHALE SHOWING THE CONTRAST ON A WEATHERED SURFACE BETWEEN THE FLAKES OF VERY RICH OIL SHALE AND THE SLIGHTLY LESS RICH MATRIX

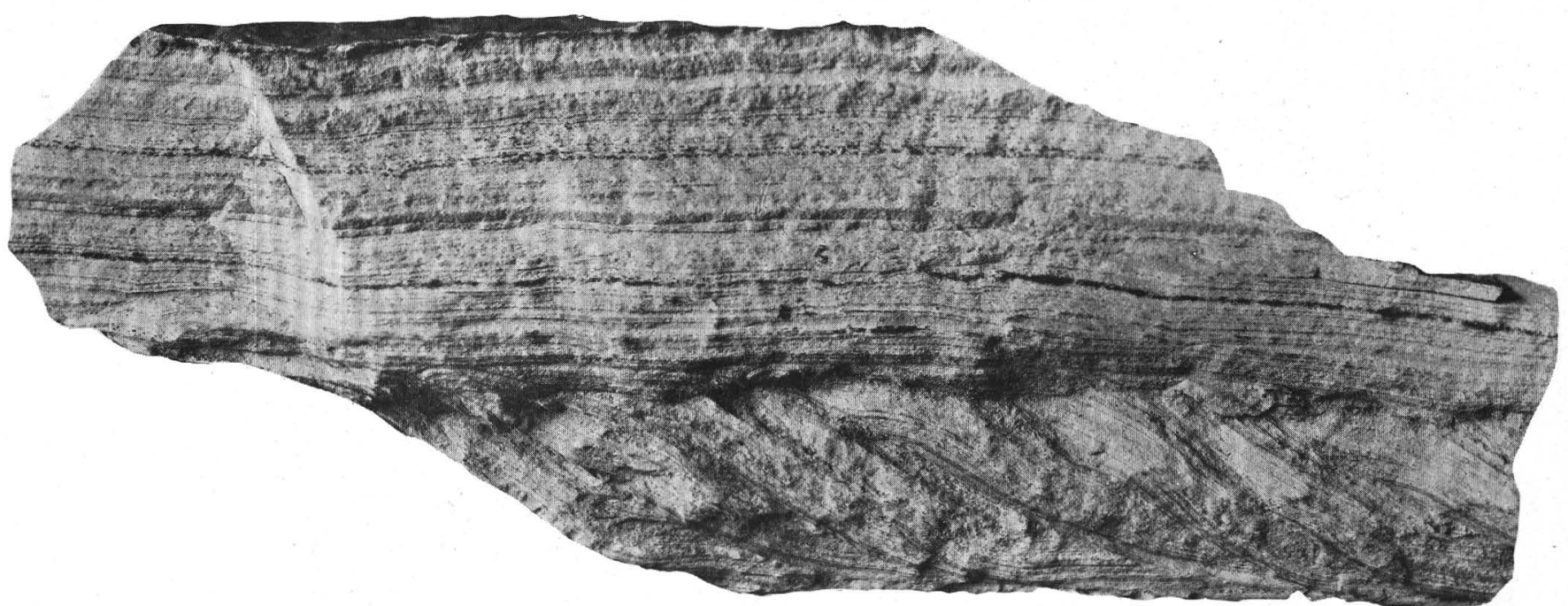

B. THIN BED OF FAIRLY RICH OIL SHALE WHICH FAILED LOCALLY UNDER STRESSES DUE TO DIFFERENTIAL COMPACTION BY DISTRIBUTIVE THRUST FAULTS

Other parts of the same bed yielded by folding. 


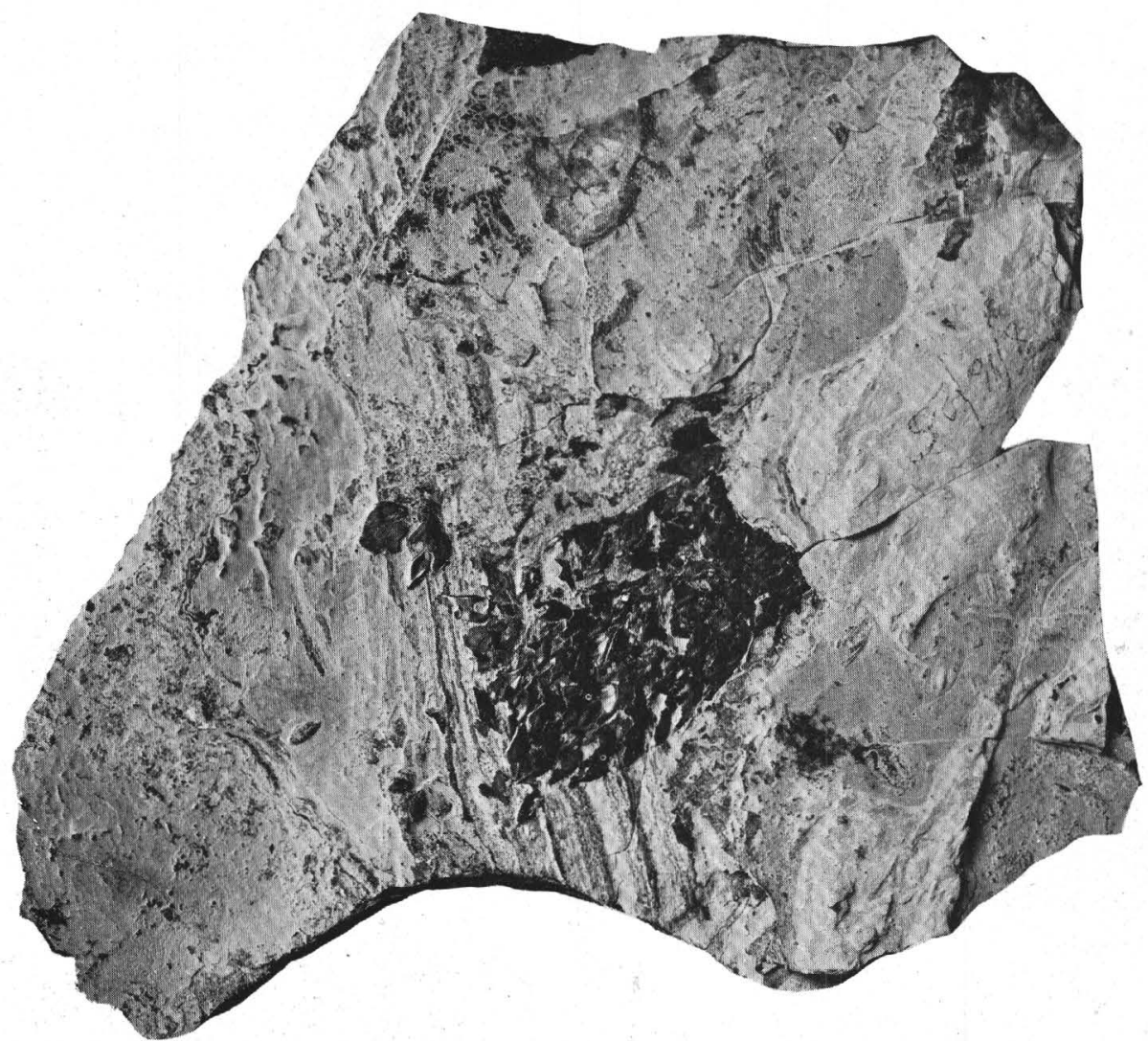

A. SPECIMEN OF OIL-SHALE BRECCIA

Shows a large fragment in the middle, oriented at a small angle with the normal bedding so that it shows its own lamination, which is quite different from that of the rock. Upon that upturned fragment is a patch of Lepidosteus scales.

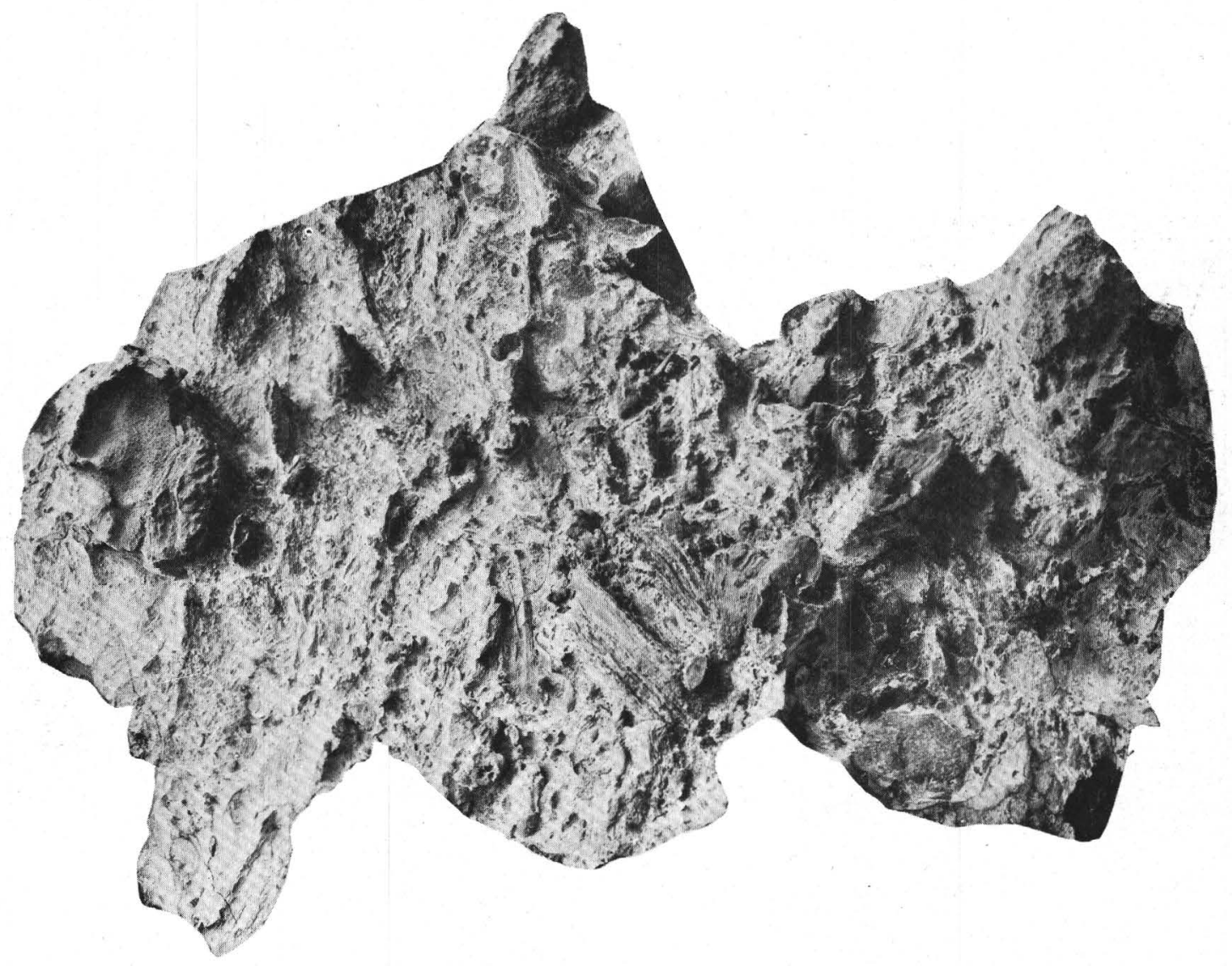

B. COARSE SHALE BRECCIA IN FAIRLY RICH OIL SHALE FROM PICEANCE CREEK, COLO. 


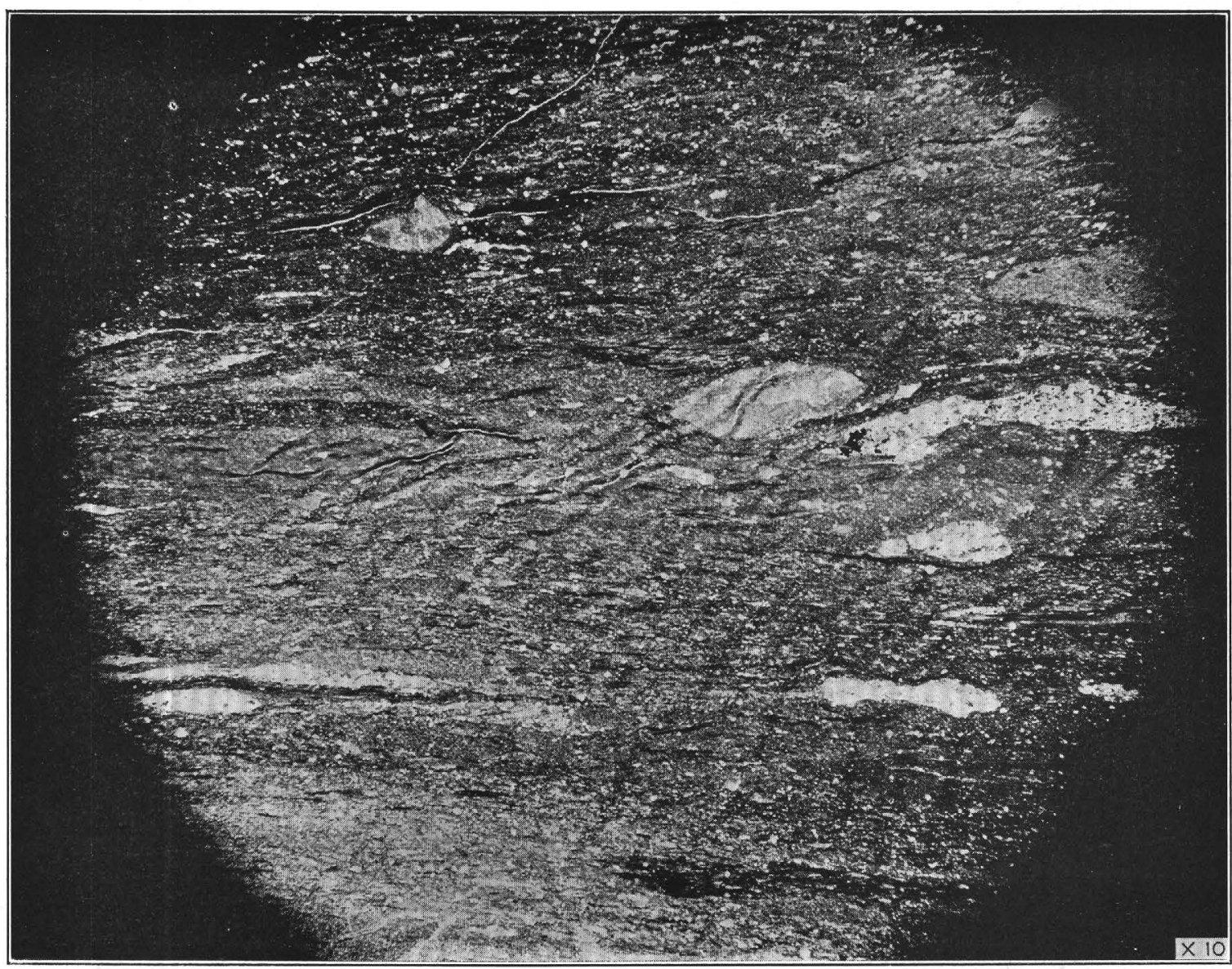

A. THIN SECTION OF A RICH OIL SHALE SHOWING SEVERAL RELATIVELY LARGE CONCRETIONS AND AN ABUNDANCE OF MINUTE CONCRETIONS, ALL OF MICROGRANULAR CARBONATES

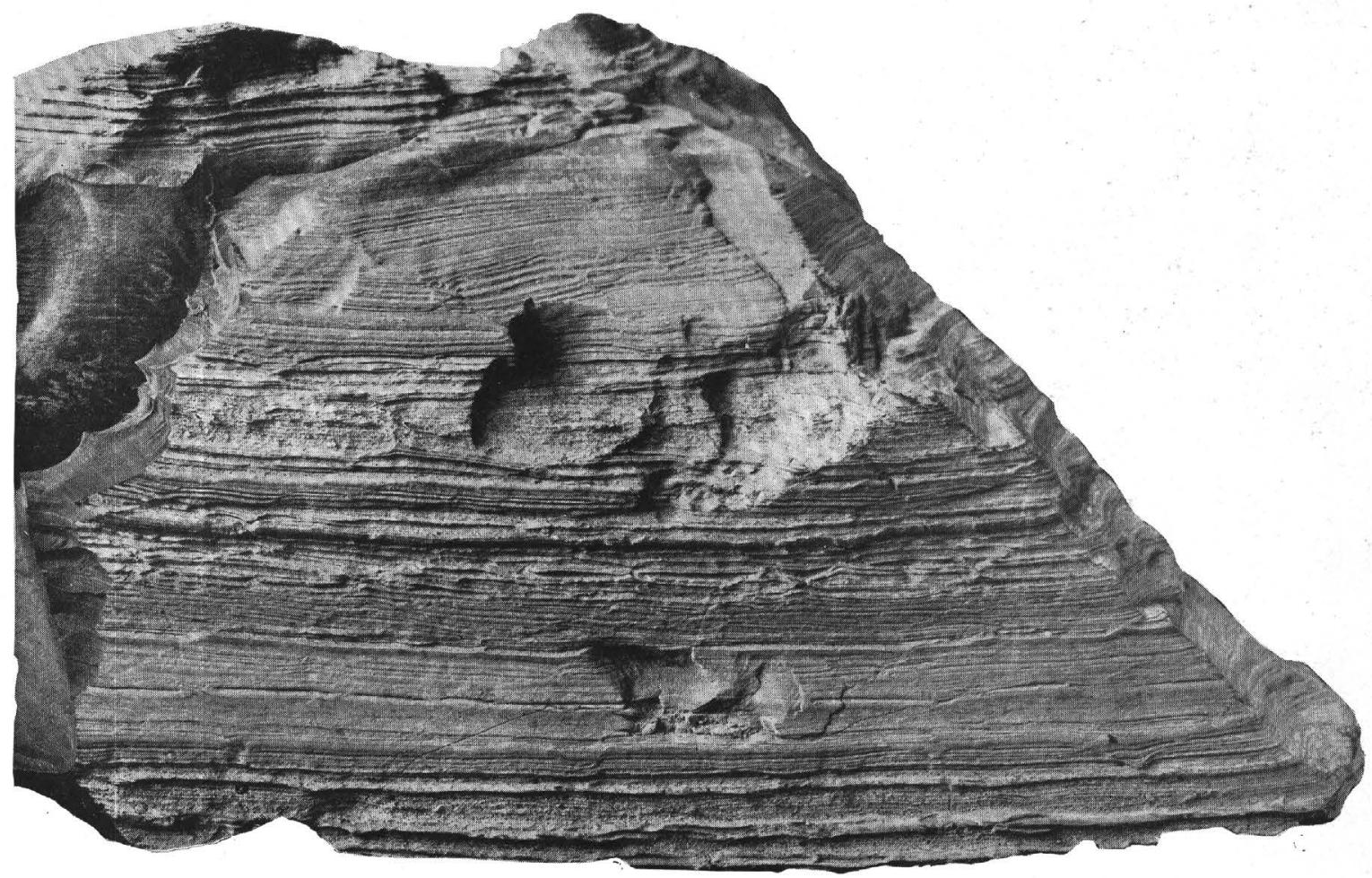

B. OIL SHALE FROM PARACHUTE CREEK, COLO., SHOWING "LOOP BEDDiNG" 


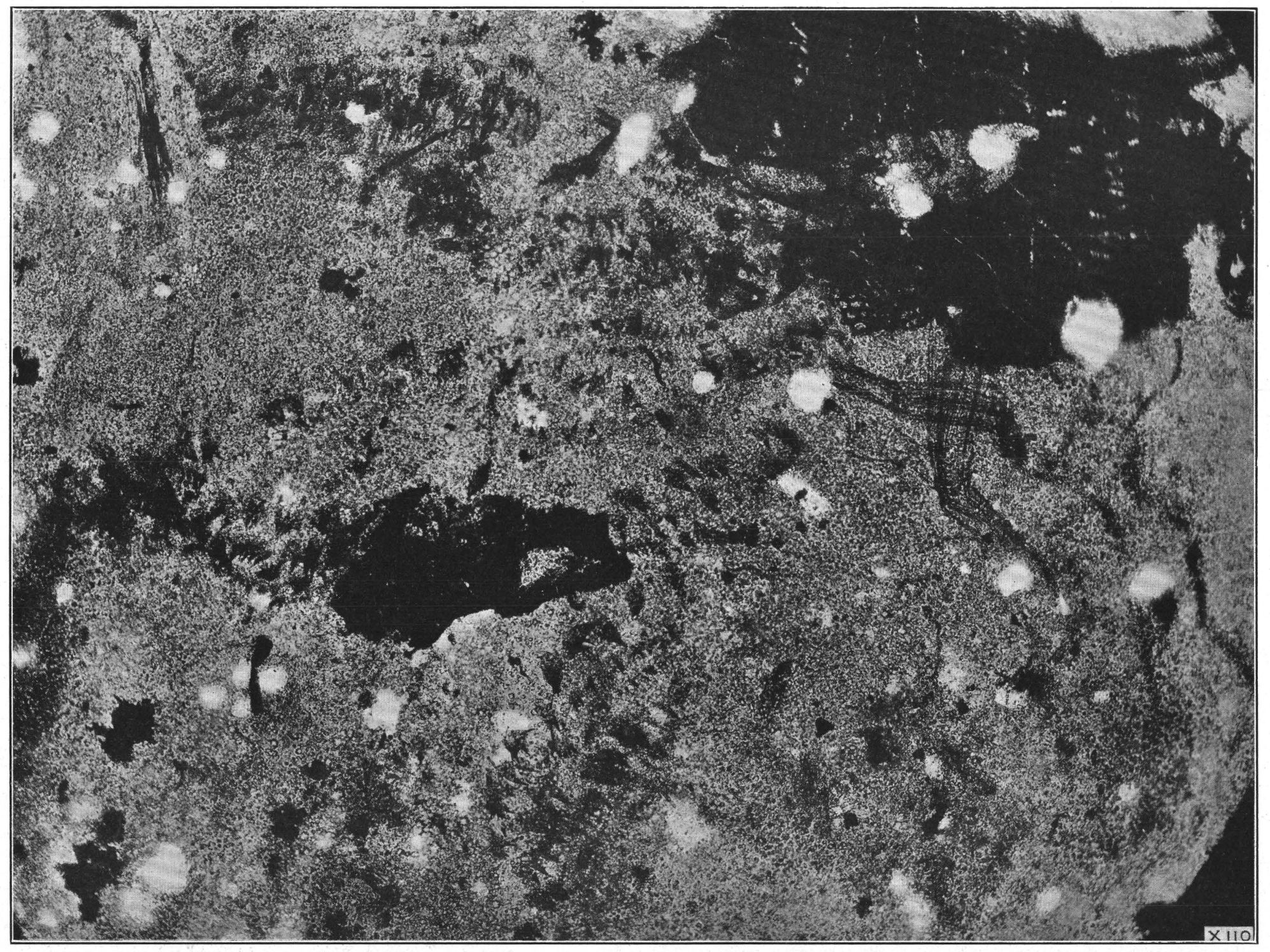

THIN SECTION OF A RICH OIL-SHALE BED FROM ASPHALT TUNNEL, SEC. 1, T. 7 S., R. 98 W., GARFIELD COUNTY, COLO., SHOWING FIGURED ORGANIC MATERIAL EMBEDDED IN A STRUCTURELESS ORGANIC GROUNDMASS

This photomicrograph shows the spines of insect larvae, probably a species of Oestridae, still arranged in tiers. It also shows parts of larval skins (the large black areas) and
fragments of the eyes and wings of minute adult insects. 
parts of the bed, where the bedding laminae are nevertheless plainly truncated.

In some beds of oil shale the differential movement has resulted in true "schuppen" structure. (See pl. 15, $B$.) In the hand specimen illustrated each plate is about 6 centimeters long and 7 to 10 millimeters thick. The thrust planes are inclined approximately $25^{\circ}$ from the horizontal; and the faulted zone has been shortened from about 41 centimeters to about 17 centimeters, or reduced to one-third its original length. This fault zone is about 4 feet long and therefore represents a differential movement of about 12 feet. Other parts of this same thin bed were evidently more plastic, for they yielded by folding.

Steep distributive thrust faults whose fault surfaces are somewhat obscured by merging of the wet, partly plastic material were found in beds of dense marlstone that is finely banded with dark-brown organic laminae.

Any of several factors may have been dominant causes of the contorted bedding and microfaulting. Floating ice that dragged along the bottom produced a comparable disturbance of the deposits in certain glacial lakes, but as there is no evidence to indicate the presence of ice in the ancient Green River lakes and much evidence that suggests its absence this possible cause may be ruled out as improbable. Deposition of the ooze upon a part of the lake bottom that sloped gently, so that a considerable thickness could be built up before the stress tending to make the material adjust itself to the inclination exceeded the rigidity, seems somewhat more likely. Now some of the oilshale beds whose laminae are deformed by flowage are as much as 3 feet thick. Before compaction by overlying deposits and before dehydration and shrinkage of the organic matter such a bed, according to an estimate by W. W. Rubey, ${ }^{61}$ of the Geological Survey, may have been about 30 feet thick. But during compaction an organic ooze of that sort loses water and becomes less fluid and more gel-like. Core samples of the deposits in a certain modern lake show that the ooze a few inches below the surface has a jellylike consistency ${ }^{62}$ firm enough to retain its laminated structure. Therefore it may be that thick beds of plastic ooze would yield by folding and flowage and where stiffer, even by faulting, to adjust themselves to a slight inclination of the bed upon which they accumulated. Essentially the same result might be produced by local abnormally rapid sedimentation. In the shallower parts of the lake the growth of organisms and also the precipitation of carbonates may have been appreciably more rapid than in the deeper parts, by reason of the slightly higher temperature. Thus the organic ooze may have accumulated more rapidly in places and built low

61 Oral commanication.

42 Whittaker, E. J., Bottom deposits of McKay Lake, Ottawa: Roy. Soc. Canada Trans., sec. 4, vol. 16, pp. 150-153, 1922.

$$
36544-31-3
$$

ridges or perhaps reef-like thickenings of the ooze layer. Such irregularities would probably tend to adjust themselves, either by flowing near the surface if the angle of repose were exceeded or by squeezing out from under the loaded areas. Local loading of ooze beds might also have occurred in other ways, such as the building out of deltas or sublacustrine slides like those described by Heim ${ }^{63}$ as occurring in the lake of Zug, Switzerland, which were due to oversteepening of the shores by local erosion. But these means seem less probable in shallow lakes that had nearly flat shores.

The differential movements and readjustments within and between the beds after burial and during compaction of the sediments may perhaps account more adequately for the contorted bedding. The irregularities in thickness of an essentially homogeneous bed of ooze would tend to smooth themselves out and so cause movement of the material from one part of the layer to another. Again, lenses poor in organic matter or lenses in which the mineral grains were for some reason unusually coarse would be less compacted than other parts and so would produce local thickenings in the layer that contained them. Then during further compaction such irregular beds, would cause unequal pressure and differential movement in adjacent more readily compactible beds. As a large part of the compaction of an argillaceous sediment occurs before it has been buried more than about 100 feet, the contortion of the beds probably. occurred when they were only shallowly buried and while at least some of the layers were still plastic. In beds containing about equal quantities of organic matter presumably those that contained a relatively large proportion of clay minerals would remain plastic longer than those that contained an abundance of calcium and magnesium carbonates, which would be likely to harden relatively rapidly. These mineralogic differences may be a part of the reason why certain oil-shale beds and particularly why thin layers within a bed are contorted, whereas others immediately adjacent and apparently identical are not. This suggested correlation between the mineralogy and contorted bedding has not been adequately tested, but of 10 thin sections from as many samples of oil shale that showed contorted bedding, 6 contained a large proportion of micaceous clay minerals and 4 contained chiefly carbonate grains, though 1 of these was exceptionally fine grained. All were very rich in organic matter. To summarize, it seems likely that contorted bedding due to differential stresses during compaction would be most commonly localized in beds that contained an abundance of organic matter, a relatively large proportion of micaceous clay minerals, and an unusually fine grained mineral aggregate.

8 Heim, Arnold, Ưber rezente und fossile subaquatische Rutschnngen und deren lithologische Bedeutung: Neues Jahrb., 1908, Band 2, pp. 137-141. 
A rather different explanation for the contorted bedding in the oil shale was proposed by David White in discussing a paper presented by Winchester ${ }^{64}$ to the Geological Society of Washington. He suggested that inasmuch as the organic muds must have remained soft for a long time after being deeply buried, they were probably deformed by differential movements between somewhat more competent beds above and below. This suggestion seems to imply that these movements were related to crustal warping.

\section{SHALE BRECCLAS}

Many of the rich oil-shale beds are apparently brecciated. They are not strictly breccias, however, for the beds themselves are not broken up. Instead they contain as inclusions many comparatively large angular fragments or flakes of more or less similar rock, which are clearly derived from the breaking up of a bed elsewhere. These fragments, then, are simply embedded in an oil shale which except for the irregular lamination is a normal oil shále. The pieces range in size from tiny flakes to fragments as much as 3 inches long. Most of them consist of oil shale whose content of organic matter differs enough from that of the matrix to make them easily distinguishable on the weathered surface. (See pl. 15, A.) Not all the fragments, however, are oil shale, some consist of marlstone. These weather buff or reddish yellow and are particularly conspicuous on the weathered surface of the rock. Most of the fragments in the shale breccias are flat and chiplike, or flakelike and are oriented nearly parallel to the normal bedding. But some are tilted at rather large angles and on their weathered edges show plainly their own lamination. (See pl. 16, $A$.) In general the boundaries of the pieces within a breccia are sharply defined, indicating that the fragments were hard before being embedded. Yet in some beds the fragments are rounded at the angles, have indistinct boundaries, and are drawn out into threadlike stringers that merge with the matrix. Moreover, several pieces that were turned so that their lamination was normal to the regular bedding were apparently soft enough to settle down, probably during compaction of the beds, with the result that they are rather minutely crenulated. In one bed a few pieces of marlstone are curved upward at the margins, suggesting mud curls, but the evidence is not conclusive. Only one of these beds has contorted bedding, and aside from the gentle irregularities of the lamination around the foreign fragments they appear to be normal beds of oil shale.

Two sorts of oil-shale breccias were distinguished in the field. One contains coarse fragments of both oil shale and marlstone which are in general oriented at appreciable angles to the bedding. (See pl. 16, B.)

4 Winchester, D.E. Contorted bituminons shale of the Green River formation in northwestern Colorado: Washington Acad. Sci. Jour., vol. 9, p. 295, 1919.
These seem to be most common near the margins of the basins, although one bed in the vicinity of Parachute Creek was locally brecciated in this manner. Shale breccias of this sort are not to be confused with beds of oil shale that contain abundant thin, flakelike lenses of iron-stained dolomite and calcite and thin ironstained concretions. Thin sections show that such inclusions are merely the thin carbonate-rich laminae of the normal oil shale or else incipient concretions. The other kind of oil-shale breceia contains great numbers of small flakes of richer oil shale, most of which are oriented nearly parallel to the lamination of the bed that contains them. (See pl. 15, A.) Shale breccia of this type, which may be termed a mosaic breccia, ${ }^{65}$ is much more common than the coarser breccia and is particularly abundant in the vicinity of Cathedral Creek, Colo,, where it was found at 13 different horizons.

White ${ }^{66}$ has called attention to the brecciated structure in the oil shale of the Green River formation, which he explains as follows:

The organic muds were evidently subject to sun cracking and scaling, and in some cases fragments of the scales appear to have fallen into sun cracks. The concentrated humic substances, being insoluble in water after once becoming dry, impart a degree of hardness and toughness or rigidity to the scales of sun-cracked organic muds, tending to preserve their integrity of form and relations when again they are submerged.

This explanation seems adequate to account for the brecciated structure. Apparently the dried and hardened scales and flakes were mixed with more organic ooze upon rise of the water level, for they appear to be embedded through several inches of atherwise normal oil shale. The flatness of the particles is perhaps to be explained by a certain amount of softening when wetted again, or by compaction of the beds.

It seems rather likely that the shale flakes in these beds were derived from areas of the lake bottom that stood a little above the water level during the low stages of the lake. Thus these shale breccias may not have any relation to the position of the shore lines. They do, however, provide strong evidence that locally, at least, the lakes repeatedly became very shallow and furthermore that at these stages there was practically no rainfall. This conclusion accords with other evidence that the climate was characterized by a seasonal. distribution of the rainfall. ${ }^{67}$

\section{MOD CRACKS}

Mud cracks are very plentiful in some parts of the Green River formation, as in the section measured along Indian Canyon, Duchesne County, Utah, where they were found at 51 different horizons. Moreover,

os Norton, W. H., Studies for students; a classification of breccias: Jour. Geology, vol. 25, p. 161, 1917.

66 White, David, The carbonaceous sediments, in Twenhofel, W. H., Treatise on sedimentation, p. $302,1926$.

or Bradley, W: H., The varves and climate of the Green River epech: U. S. Oteol. Survey Prof. Paper 158, pp. 90-95, 1929. 
at most of these horizons many bedding planes are cracked. White also found mud-cracked beds of High-grade oil shale in the Green River formation in northeastern Utah.

Sharply defined mud cracks filled with light-gray mudstone were found by the writer on the bedding planes of rich oil shale at about $3,100,3,400$, and 3,450 feet above the base of the formation near the head of Avintaquin Canyon, about sec. 27, T. 10 S., R. 8 W., Duchesne County, Utah. The uppermost of these beds is particularly significant, for the thin, mudcracked laminae also show mosaic brecciation, a fact which strengthens the hypothesis that the shale breccias are due to desiecation. The leaner shale and siltstone beds associated with the mud-cracked rich oil-shale beds in this part of the section are also mud cracked. A bed of rather low grade oil shale with excellent mudstone-filled mud cracks on its upper surface was found about 850 feet above the base of the formation in the canyon of the White River in sec. 27, T. 9 S., R. 25 E., Uintah County, Utah. Upon that mud-cracked surface rests a thin bed of very rich oil shale.

Comparatively few bedding planes of the oil shale are exposed so that the surface features can be seen, but the edges of the beds in the cliff face show plainly a structure which the writer regards as possibly due to mud cracks and which he recorded in his field notes as "loop bedding." Small groups of laminae that are otherwise quite regular are sharply constricted or even end abruptly at intervals, giving the effect of long, thin loops or links of a chain. (See pl. 17, B.) The groups of laminae so interrupted range from about one-sixteenth to about one-fourth inch in thickness. The intervals between constrictions range from about three-eighths inch to more than 5 inches. At the constrictions the uppermost and lowermost laminae of the affected groups converge abruptly and apparently pinch off the intervening laminae. Yet at many constrictions the upper and lower laminae do not end; instead they merely approach one another, then separate again to their normal distance apart. This detail of the structure can be best observed in thin sections. It is also clear from examination of thin sections and polished specimens of "loopbedded" oil shale that the central laminae of such constricted groups have indefinite terminations, which apparently indicates that the structure was formed when the original mud or sapropel was moist and plastic. These "loops" may possibly be explained as cross sections of mud cracks formed on a wet mud flat. The fact that the uppermost and lowermost laminae of each group are very clearly defined where they converge seems to preclude the possibility that the walls of the cracks were ever nearly vertical

os White, David, The carbonaceous sediments, in Twenhofel, W. H., Treatise on sedimentation, p. 302, fig. 43, 1926. and were bent or slumped down at the angle when they were again covered by water. Rather it seems that the mud dried out to a certain depth, so that a surface layer comprising a group of laminae contracted into polygonal blocks, which however, shrank more along the margins of the polygons, thus becoming somewhat lentil-shaped. These units may not. have dried sufficiently to curl up or, what is perhaps more probable, they were wet with more or less saline water and consequently showed no tendency to curl. The layers that broke into lentil-like polygons were surely much thicker at the time the mud was cracked, and the cracks may have been as much as several inches deep.

"Loop bedding" was observed only in beds of oil shale that were estimated to be capable of yielding at least 15 gallons of oil to the ton and only in that part of the formation above the base of the Parachute Creek member. Furthermore, in that part. of the formation many of the richer beds contain an abundance of salt crystal cavities. Beds that contain "loop bedding" were observed at 23 horizons in the Parachute Creek section, 10 horizons in the Cathedral Creek section, and 10 horizons in the White River section in Utah. "Loop bedding" was not studied very critically in the field, where its significance was not realized, and it is probable that a careful search would reveal this structure at many more horizons in the upper part of the formation.

\section{IINERALOGY}

\section{SYNGENETIC MINERALS}

Calcite and dolomite.-Calcite and dolomite are the predominant minerals of both the rich and the lean oil-shale beds of the Green River formation. The grains, which are essentially equidimensional, average about 0.008 millimeter in diameter, but some are less than 0.001 millimeter and a few as much as 0.038 millimeter. Perfect rhombs of either dolomite or calcite are also fairly plentiful and are of about the same order of size. It seems more likely that these idiomorphic crystals are dolomite, but there is no evident relation between the number of rhombohedral crystals and the magnesium content of the shale.

Lime and magnesia determinations have been made on 10 different samples of oil shale, and the relative proportions of dolomite and calcite in these rocks have been calculated. In these calculations it was assumed that all the $\mathrm{MgO}$ was combined as dolomite. One shale from Fossil Butte, Wyo., contains 45.3 per cent of dolomite and 7.1 per cent of calcite, whereas another from Green River, Wyo., contains 56.6 per cent of calcite and only 22.2 per cent of dolomite. These two samples represent the extremes. The average of the other seven analyses shows 35.6 per cent of dolomite and 16.5 per cent of calcite. This 
may be regarded as a fair average for the dolomite content of the Green River oil shales.

The dolomite was cTearly formed before solidification of the rock, for the organic matter through which the fine carbonate grains are scattered is almost wholly impervious to solutions. The dolomite may have been formed by a simultaneous precipitation of the calcium and magnesium carbonates, which later combined to form the double salt, or it may have formed by reaction between solutions of magnesium salts and the minute calcite grains soon after. they were precipitated. Or again the dolomite may have been precipitated as the double salt. There is no petrographic evidence to favor any one of these hypotheses more than another. Most of the grains of both dolomite and calcite are anhedral; some are euhedral. There is apparently no differentiation in size between the two carbonates.

According to Clarke ${ }^{60}$ the experiments of Scheerer and Hoppe-Seyler showed that finely divided calcium carbonate will precipitate magnesium carbonate from its solution in sea water. Clarke also says that in this process the mixed carbonates form and not true dolomite, but that if given sufficient time they might unite in the cold to produce dolomite, in much the same way that Klement made them combine rather rapidly by elevating the temperature. Van Tuyl, ${ }^{70}$ however, regards this process as less probable than a precipitation of the calcite grains, which soon thereafter react with the magnesium salts in solution to form magnesium carbonate, which in turn immediately combines with the calcium carbonate to form dolomite. Some experimental work done under conditions more nearly simulating those within a decomposing organic ooze are evidently necessary before the way in which the dolomite of the oil shale was formed can be determined.

Analcite and sepiolite.-Analcite crystals are scattered through many oil-shale beds and in a few make up as much as 16 per cent by weight of the rock. The crystals average about 0.065 millimeter in diameter but range from about 0.004 to 0.15 millimeter. They are clear and wholly isotropic and contain inclusions of minute irregular grains and rhombs of carbonates and tiny flakes of clay minerals. In general, those larger than 0.03 or 0.04 millimeter in diameter have been distinctly flattened parallel to the bedding laminae. Vertical sections of some of these crystals show only vague or badly distorted crystal faces, but considered together with the horizontal sections they show that the crystals are clearly trapezohedrons that have been compressed to only about half their normal diameters during the compaction of the shale. More-

\footnotetext{
To Clarke, F. W., The data of geochemistry, 5th ed.: U. S. Geol. Survey Bull. 770, p. 671, 1924 .

70 Van Tuyl, F. M., The origin of dolomite: Iowa Geol. Survey Bull. 45, pp. 400401, 1914.
}

over, these distorted crystals contain many irregular. cracks. The general distortion of the arialaite crystals in oil shale seems to indieate that they were formed when the shale was only shallowly buried; for a large: part of the compaction of an argillaceous sediment occurs before it has been buried to a depth of as much. as 100 feet. Minute apophyllite erystals are rather consistently associated with the analcite. Most of these are prismatic and range between 0.02 and 0.03 millimeter in length. Considerable evidence has been assembled which indicates that both minerals were formed in place on the lake bottom as a result of interactions between various salts dissolved in the lake water and the dissolution products of volcanic ash that fell into the lake. This evidence has been presented and fully discussed in another report. ${ }^{\text {11 }}$

The principal inorganic constituent of a few thin beds of rather rich oil shale is fibrous sepiolite. These beds, all of which are less than 1 centimeter thick, were found about 4,400. feet above the base of the formation in Indian Canyon, near the middle of T. $10 \mathrm{~S}$., R. 7 W., Duchesne County, Utah. The weathered surface is light bluish gray and has a distinctly silky luster. Below the weathered surface the rock is dark grayish brown. Like some other oil-shale strata of this formation it has a pronounced fissility and resembles matted coarse brown-paper pulp. Unlike. other oil shales, however, it is light enough when dry to float on water. An analysis and the physical and optical properties of the sepiolite have been given. elsewhere by the writer. ${ }^{72}$

Pyrite.-Pyrite occurs in various amounts in all the oil shale of the Green River formation. The greater part of it is in subspherical or irregular grains that range from 0.002 to about 0.05 millimeter in diameter, but in some beds; particularly the very rich beds in the eastern part of Uintah County, Utah, there are numerous discoid aggregates of microgranular pyrite from. 0.5 to 3 millimeters across. In vertical section it is clear that these aggregates have a sort of laminate structure and that the thin edges of successive disks interfinger with the microscopic laminae of the oil shale. Radial aggregates of elongate rodlets of pyrite were also found in some beds, but cubes or other crystal forms are less common.

Most if not all of the pyrite in the oil shale formed in place on the lake bottom while the organic ooze was still soft. Hydrogen sulphide is a characteristic byproduct of the putrefactive process through which the greater part of the organic matter in oil shale has passed and during which nearly all the minute aquatic organisms were reduced to a more or less fluid gel. Thus the organic ooze contained a plentiful supply of hydrogen sulphide, which would have reacted with any.

${ }^{71}$ Bradley, W. H., The occurrence and origin of analcite end meerschaum beds in the Green River formation: U. S. Geol. Survey Prot. Paper 158, pp. 4-6, 1929.

72 Idem, pp. 6-7. 
iron salts dissolved in the lake water to form iron sulphide. This theory is apparently supported by the abundance of pyrite in the organic ooze now forming. Furthermore the pyrite so formed seems to have a distinctive microgranular or rather microspheritic habit. Naumann ${ }^{73}$ has described in considerable detail these minute spherioal or subspherical grains that characterize pyrite formed in putrescent organic lake ooze. These grains, which range from one to several thousand ths of a millimeter in diameter, show a marked tendency to aggregate into larger spheroidal masses 0.01 to about 0.025 millimeter in diameter. He found that minute grains and agglomerated masses of them occur together with cubical grains of pyrite in the skeletal parts of dead plankton organisms, such as the Cladocera, and within the cells of partly decomposed plant tissue. Clearly the pyrite forms contemporaneously with the decay of the organic matter and therefore very soon after its deposition. Potonie ${ }^{74}$ also has described minute spherical grains of pyrite within and associated with the remains of plankton organisms in the fetid organic ooze from the Black Sea. The analogy between the occurrence of microgranular pyrite in recent lacustrine organic ooze and the occurrence of nearly identical granular aggregates of pyrite in the organic matter of the oil shale leads the writer to believe that the pyrite in oil shale formed contemporaneously with the deposition and putrefaction of the original organic ooze. Furthermore, the pyrite is more or less intimately intergrown with the analcite crystals, which seem clearly to have formed soon after deposition of the ooze. A small quantity of marcasite was also found in some of the shale beds.

Quartz and opal.-A few minute bipyramidal quartz prisms were found in several rich oil-shale beds. These seem to have grown while suspended in the organic ooze. Opal occurs in rather small quantities in the oil shale.

\section{CLASTIC MINERALS}

The predominant clastic constituents of the oil shale are clay minerals belonging to the beidellite group. In some beds these minerals make up as much as 21 per cent of the rock. They occur as isolated micaceous flakes of irregular shape that range from 0.03 to 0.045 millimeter in diameter or as minute lathlike flakes, few of which exceed 0.01 millimeter in length. According to the indices of refraction $(\alpha=1.50 ; \beta, \gamma=1.54)$

\footnotetext{
7a Naumann, Einar, Über das Auftreten der verschiodenen Eisenverbindungen in den limnisehen Ablegerungen: Sveriges geol. Undersokning Årsbok, ser. C, N.o. 289, p. 39, 1918

u Potonie, H., Die rezenten Kaustobiolithe und ihre Lagerstätten: K. preuss. geol. Landesanstalt Abh., new ser., Heft 55, Band 1, p, 213, 1908.
}

this mineral probably contains 8 or 9 per cent of iron, and its composition is therefore near that of the type beidellite, whose composition and optical properties were determined by Ross and Shannon.75 Grains of quartz, sanidine, orthoclase and plagioclase feldspars, muscovite, zircon, and apatite were also found in the oil shale, but they are not abundant. Quartz and feldspar grains are more common than flakes of muscovite and crystals of zircon and apatite, which are really rare. Many of the grains of quartz and feldspar are either sharply angular or subangular and range in size from about 0.01 to about 0.16 millimeter. However, a fair proportion of the sanidine and orthoclase crystals are euhedral, and in a few beds euhedral crystals of plagioclase, hornblende, and pyroxene were found. In addition to these minerals some beds contain a few scattered fragments of volcanic glass which is partly replaced by analcite. The most striking feature of the clastic grains, other than the clay. minerals, is their complete lack of sorting and their random arrangement. They are not assembled in layers but disseminated through the deposit, and the large and small sizes are intermingled without semblance of order. This arrangement of the minerals the predominance of sanidine over orthoclase, the association of euhedral crystals of sanidine, orthoclase, plagioclase, ferromagnesian minerals, and volcanic glass, and the prevalence of analcite and apophyllite imply that a considerable portion of the clastic minerals are of volcanic origin. Moreover, thin ash beds are $<$ rather common in the Parachute Creek member, which is the oil-shale member of the Green River formation. Nevertheless, probably the greater part of the clastic material was brought into the lake by streams and distributed by currents. Some may also have come in as wind-blown dust, though no grains with a mat surface have been observed.

The inorganic constituents of two samples of rich oil shale have been analyzed in the chemical laboratory of the United States Geological Survey. One of these samples (No. 17) was obtained just below the "mahogany ledge" in the Monarch Shale Oil Co.'s mine in sec. 32, T. 6 S., R. 97 W., Garfield County; Colo., and is characterized by an abundance of analcite. The other (No. 111) came from the "mahogany ledge" near the head of the East Middle Fork of Parachute Creek, in sec. 10, T. 5 S., R. 95 W., Garfield County, Colo., and is characterized by a predominance of clay minerals. The analyses are given on page 32 , together with the computed mineral composition.

76 Ross, C. S., and Shannon, E. V., The chemical composition and optical properties of beidellite: Washington Acad. Sci. Jour., vol. 15, pp. 467-468, 1926. 
Analyses of mineral portion of oil shales from the Green River formation

[J. G. Fairchild, analyst]

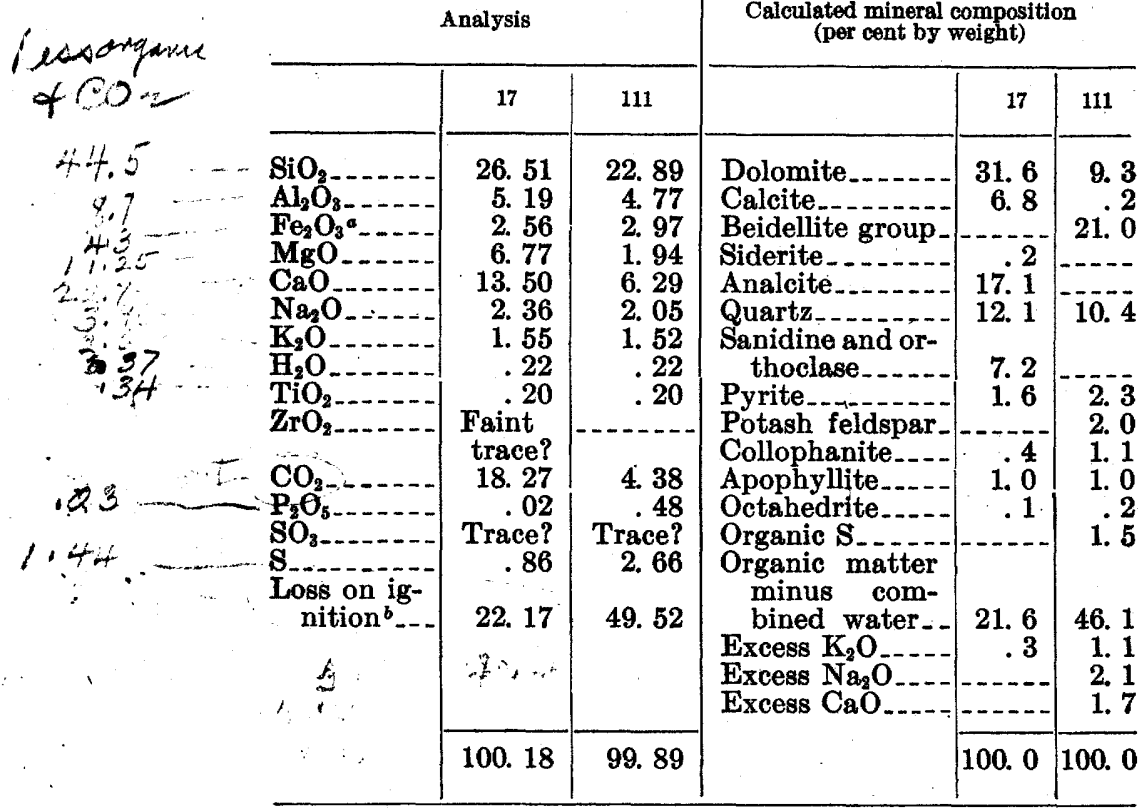

- From total $\mathrm{Fe}$

- Loss on ignition less $\mathrm{CO}_{2}$ includes $\mathrm{H}_{2} \mathrm{O}$ of hydrous minerals.

Estimated oil yield, No. 17, 38 gallons to the ton; No. 111, about 60 gallons to the ton.

The mineral composition as calculated from the analysis of No. 17 is fairly satisfactory and agrees well with estimates of the more plentiful minerals made by petrographic methods. The quantity of dolomite was computed by calculating out $\mathrm{MgO}$ and $\mathrm{CaO}$ as magnesite and calcite and then uniting all the magnesite with a chemically equivalent amount of calcite. Collophanite was not recognized under the microscope, but it seems to be a reasonable mineral to postulate to account for the $\mathrm{P}_{2} \mathrm{O}_{5}$. Apophyllite was recognized, and its quantity estimated at about 1 per cent. The excess $\mathrm{K}_{2} \mathrm{O}$ is probably adsorbed on the finest mineral particles.

The mineral composition as calculated from the analysis of No. 111 is much less satisfactory, yet it will serve to show approximately the proportions of the different minerals. In most beds of oil shale the carbonates predominate, but in this rock clay minerals belonging to the beidellite group are the principal mineral constituents. The beidellite occurs as irregular flakes from 0.20 to about 0.1 millimeter in diameter. It is optically negative, its refractive indices are $a=1.50, \beta, \gamma=1.54$, and the axial angle is rather large. The other clay mineral occurs as very minute lathlike flakes whose refractive indices are close to those of beidellite, but the birefringence is lower. The quantities of beidellite, potash feldspar, and apophyllite were estimated under the microscope, and then the remaining $\mathrm{Al}_{2} \mathrm{O}_{3}$ was computed according to the formula of montmorillonite, which though formerly regarded as a distinct mineral species is now regarded by C. S. Ross, ${ }^{76}$ of the Geological Survey, as a member of the beidellite group of clay minerals. The excess $\mathrm{CaO}$ is puzzling, but the $\mathrm{Na}_{2} \mathrm{O}$ and $\mathrm{K}_{2} \mathrm{O}$ are probably in large part adsorbed on other small mineral particles. The rock contains also a very small quantity of analcite, which would account for a part of the excess $\mathrm{Na}_{2} \mathrm{O}$. In both rocks the quantity of organic matter was determined by subtracting the percentage of water in the hydrous minerals from the loss on ignition minus $\mathrm{CO}_{2}$. As small quantities of both vanadium and chromium are commonly associated with well petroleum, sample 17 was tested for $\mathrm{V}_{2} \mathrm{O}_{3}$ and $\mathrm{Cr}_{2} \mathrm{O}_{3}$, but no trace of either was found.

\section{SALINE MINERALS AND THEIR SIGNIFICANCE}

Salt-crystal cavities are very plentiful at certain levels in the Green River formation. Some of these have been examined by W. F. Foshag, of the United States National Museum, and W. T. Schaller, of the United States Geological Survey, who have measured the angles and concluded that they probably represent glauberite and anhydrite. The occurrence of these crystal cavities and the measurements of the angles have been given in an earlier report. ${ }^{77}$

The relative abundance of the salt molds in certain parts of the formation furnishes the basis for some interesting speculation as to the approximate length of the stages of the ancient Uinta Lake. when it had no outlet and the dissolved salts accumulated and also as to the stages when the lake appears to have been freshened by at least intermittent overflow. These speculations are based in part on the distribution of the salt molds in the 'saline phase of the Green River formation as exposed in Indian Canyon, Utah, in part on the distribution of salt molds in the Green River formation in Wyoming, and in part also upon the inferred relations between the area of the ancient Gosiute Lake and its hydrographic basin (in Wyoming) and the climate that prevailed in the vicinity of that basin during the Green River epoch. ${ }^{78}$

In the western part of the Uinta Basin, in the vicinity of Indian Canyon, the Green River formation contains a zone a little more than 800 feet thick in which molds of saline minerals are more or less plentiful. Glauberite(?) is the predominant mineral represented, but several thin beds contain pseudomorphs or molds of an unknown mineral, presumably an alkali salt. Units within this zone that contain molds of glauberite(?) range in thickness from a few inches to 65 feet. They are separated by units of shaly marlstone and shale, which are generally thinner and which show no trace

\footnotetext{
76 Personal communication.

7 Bradiey, W. H., The occurrence and origin of analcite and meerscheum beds in the Green River formation: U. S. Geol. Survey Prof. Paper 158, p. 5, 1929.

78 Bradley, W. H., The varves and climate of the Green River epoch: U. 8. Cieol.
} Survey Prof. Paper 158, pp. 93-95, 106-107, 1929. 
of saline material. Nearly all the beds in this phase of the formation are limy, and most of them also contain some organic matter. A few of the beds, in fact, are moderately good oil shale, but the others are of low grade. At places the rocks are silty or even sandy and micaceous, and at wide intervals in the unit there are thin beds of micaceous sandstone and muddy limestone. The prevailing color range of the rocks is from graybuff to light chocolate-brown, but in the upper part many beds have an odd pinkish or lavender tone. Mud cracks are characteristic of the entire saline phase and are intimately associated with the impressions of the saline minerals. (See pl. 10, B.) The distribution of the various saline beds within the zone is shown in Figure 3.

As in the rocks of the saline phase of the Green River formation near Green River, Wyo., the layers of glauberite(?) molds in many beds of this phase in the Uinta Basin recur at rather regular intervals. Yet in those beds in which the molds make up perhaps as much as 50 per cent of the rock by volume either there is no rhythmic arrangement or the cycle of salt deposition was so short that its effect is obscured by the closeness of the salt-mold layers and their relatively large size. On the other hand, molds are so sparsely scattered through other beds that no systematic arrangement is discernible. In a specimen of comparable rock, though somewhat richer in organic matter, collected by the writer from the saline phase of the Green River formation in Wyoming the average interval between layers of salt molds is 3.4 millimeters. According to the varves in the intervening layers of oil shale the interval of salt (glauberite?) deposition recurred about every 50 years. ${ }^{79}$

The writer estimates that each layer of salt molds in this specimen represents a layer of solid glauberite about 0.5 millimeter thick. If this amount of material came into the lake in solution during each 50-year period intervening between times of salt deposition, then the annual increment of the constituents necessary for glauberite would be equivalent to 0.01 cubic centimeter or 0.27 gram of glauberite per square centimeter of lake bottom. This much glauberite contains 0.0186 gram of $\mathrm{SO}_{4}$. A measure of the total dissolved solids in the streams feeding the lake can now be obtained if a ratio between the $\mathrm{SO}_{4}$ and the total dissolved solids is assumed. For reasons explained below the Santa Maria River, in southern California, is taken as representative of the ancient streams in the Green River region. According to Clarke ${ }^{80} \mathrm{SO}_{4}$ constitutes about 52 per cent of the total dissolved solids in the water of this river. 'Using this figure would make the annual increment of total dissolved solids 0.0276 gram for each square centimeter

78 Bradley, W. H., op. cit. (Prof. Paper 158), pp. 106-107.

60 Clarke, F. W., The composition of the river and lake waters of the United States: ठ. 8. Geol. Survey Prof. Paper 135, p. 138, 1924. of lake bottom. Suppose next during each 50-year period the lake did not overflow but that evaporation balanced precipitation. Then the difference between the average annual precipitation over the land area of the drainage basin and the average annual evaporation from the land and plant surface will represent the runoff, or the annual increment of stream water reaching the lake. According to the estimates of rainfall and evaporation in the basin of the ancient Gosiute Lake given by the writer in an earlier paper, ${ }^{81}$ this figure is approximately 2.3 inches (5.84 centimeters). Hence, if the assumed annual increment of $0.0276 \mathrm{gram}$ of dissolved solids per square centimeter of lake bottom was brought to the lake in the streams they must have had an average concentration of about 4,700 parts per million of total dissolved solids.

The Santa Maria River is a torrential river in a region with a semiarid climate. It has an exceptionally large content of dissolved solids (2,412 parts per million), and of those solids $\mathrm{SO}_{4}$ makes up an exceptionally large percentage. The Santa Maria River was chosen for this calculation, not because it was regarded as having a particularly close resemblance to the streams that fed the ancient Gosiute Lake, but because of its high percentage of sulphates, which would make the estimate of the total dissolved solids carried in the ancient streams a minimum. Even by using for the ancient streams the improbably high percentage of sulphates found in the Santa Maria River, which would give the lowest possible concentration, the calculation indicates a concentration of about 4,700 parts per million of total dissolved solids. The writer has estimated by two independent methods that the average annual rainfall of the Gosiute Lake Basin was of the order of 30 to 40 inches, ${ }^{82}$ and inasmuch as few or perhaps none of the streams that fed Gosiute Lake could have been very long, this concentration or even one-quarter of it seems excessive. Because the assumption that all the material for each thin glauberite layer accumulated in the lake during the 50-year interval between times of salt deposition requires an improbable concentration of dissolved solids in the feeding streams, it seems valid to regard this assumption as wrong and to conclude on the contrary not only that the saline constituents had been accumulating for a relatively long time before the first glauberite began to form but also that this reserve of salts was being drawn upan, to some extent at least, as long as layers 0.5 millimeter thick continued to form at intervals of 50 years. Although a part of the saline phase of the Green River formation near its type locality in Wyoming has been used to reach these conclusions, the saline phase in the western part of the Uinta Basin is so similar that in a general way conclusions reached from a study of one will apply equally. well to the other.

B1 Bradley, W. H., op. cit. (Prof. Paper 158), pp. 91-93

Idem, pp. 91-03 


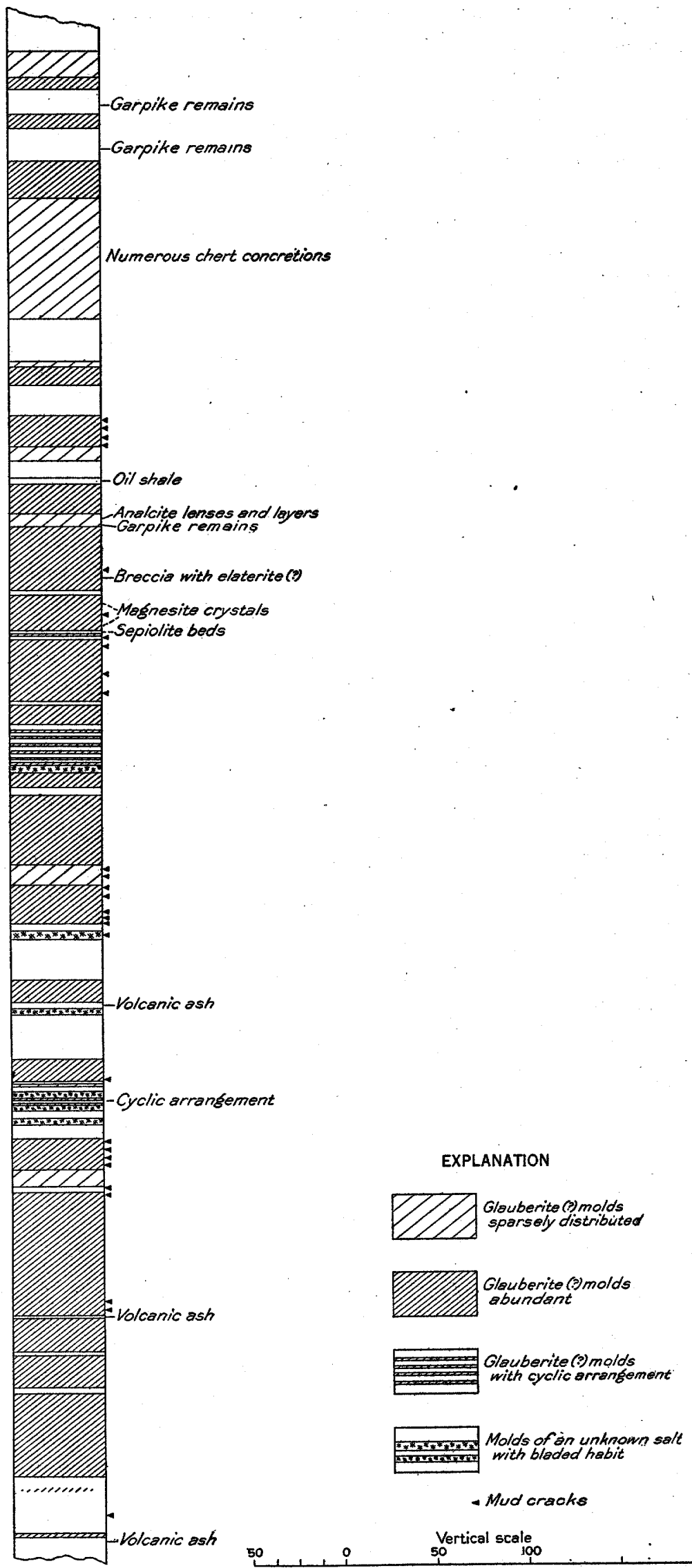

FIGURE 3.-Columnar section of the saline phase of the Green River formation in Indian Canyon. Duchesne County, Utah, showing the distribution of the salt molds, mud cracks, fossils, and volcanic-ash layers and the positions at which a fow unusual minerals occur 
Hence the ancient Green River lakes may be pictured as without outlet for long periods of time during the saline phase. While the lakes occupied closed basins the water volume apparently fluctuated periodically and at the extreme low levels precipitated some of its salt. However, as much of the salt or rather its molds are found on deeply mud-cracked bedding planes it may well be that even at the extreme low levels the brine was not so concentrated that glauberite crystallized from it, but rather that as the lake shrank salt formed only on the mud flats as the result of excessive evaporation. The higher temperature of the mud and the thin sheet of water at the strand line would also favor the formation of glauberite, for according to Van't Hoff ${ }^{83}$ glauberite can be precipitated by itself from solutions saturated with respect to gypsum and the decahydrate of sodium sulphate only between the temperatures of $29^{\circ}$ and $32.4^{\circ} \mathrm{C}$. $\left(84.2^{\circ}\right.$ and $90.3^{\circ}$ F.). Below $29^{\circ} \mathrm{C}$. gypsum forms, and above $32.4^{\circ} \mathrm{C}$. the anhydrous sodium sulphate thenardite crystallizes out. But the presence of other common salts tends to lower the temperature limit for glauberite, and Van't Hoff ${ }^{84}$ also shows that glauberite will form at temperatures as low as $10^{\circ} \mathrm{C} .\left(50^{\circ} \mathrm{F}\right.$.) if the brine is saturated with respect to sodium and potassium chlorides and magnesium sulphate as well as gypsum and Glauber's salt. As it is likely that chlorides, as well as the bases magnesium and potassium, were present in the waters of the ancient Uinta and Gosiute Lakes, the actual temperatures at which the glauberite formed probably varied with the composition of the brine and were generally less than the maximum possible temperature of $90^{\circ} \mathrm{F}$. No traces of thenardite, halite, or primary gypsum have been found directly associated with the glauberite(?) impressions, and hence the composition of the water and the environmental conditions probably were nearly alike each time the lake reached a stage of salt deposition. Different conditions are indicated by only six thin beds in the saline phase of the Green River formation in the western part of the Uinta Basin, where the saline zone is a little more than 800 feet thick. These beds indicating different conditions contain abundant molds of an unknown platy mineral, which is presumably, however, an alkali salt.

Although for very long periods during the saline phase the lake had no outlet, there were also intervals of considerable length in which the eoncentration of dissolved material was diminished and the lake may even have been freshened by occasional overflow. Several of these intervals are indicated in the saline phase in the western part of the Uinta Basin by units of shaly marlstone that contain remains of ganoid fish but no traces of salt and relatively few mud cracks.

69 Van't Hoff, J. H., Untersuchungen über die Bildungs-verhăltnisse der ozeanischen Salzablagerungen: K. Akad. Wiss. Berlin Sitzungsber., 1005, pp. 478-479. 4 Idem, pp. 482-483.

$36544-31-4$
One of these barren units is 24.5 feet thick. If the rate of sedimentation inferred from the varves in the marlstone beds of the Green River formation in Colorado ${ }^{85}$ is assumed, namely about 2,000 years to the foot, then this unit represents a little less than 50,000 years. If it is assumed that during this interval the streams which fed the ancient Uinta Lake had an average concentration of about 72 parts per million (the average concentration of 17 rivers in the South Atlantic States) ${ }^{86}$ and that the average annual run-off amounted to a layer of water 2.3 inches (5.84 centimeters or in round numbers 6 centimeters) deep per unit area of the lake surface and a layer of water of equal depth was lost from the lake by evaporation, as has been estimated for the ancient Gosiute Lake, ${ }^{87}$ which lay north of the Uinta Mountains, then it will be possible to test the hypothesis that it was necessary for the lake to overflow, for a short time at least, during this 50,000-year interval in order that the thickest barren marlstone unit in the Indian Canyon saline zone could have been deposited free from salt. Assume that the lake was entirely fresh and had an average depth of about 50 feet ( 15 meters). Consider a unit column of the lake water 1 centimeter square in cross section and 1,500 centimeters (about 50 feet) deep. Each year for 50,000 years the amount of solids dissolved in 6 cubic centimeters of the stream water, whose concentration is about 72 parts per million, is added to this column of lake water; but the volume of the column remains constant, for in each year a layer 6 centimeters deep is lost from the lake surface by evaporation. The total dissolved solids in 1 cubic centimeter of the stream water amount to $0.000072 \mathrm{gram}$, and as the annual increment of stream water per unit area is 6 cubic centimeters the annual increment of solids to the unit column would be 0.00043 gram and in 50,000 years about 21.5 grams. This amount of material dissolved in the unit column would give the water a concentration of a little more than 1,400 parts per million, which is far below that necessary to precipitate out salts like glauberite. If the lake instead of being nearly full at the beginning of this interval had been quite low, as it probably was just after salt deposition, and had expanded considerably during the deposition of the marlstone unit that contains no salt molds, it seems likely that the resulting concentration of the lake water would have been of about the same order of magnitude, despite the fact that the small volume of water in the lake at the beginning of this interval would probably have been a strong brine. From these considerations it is perhaps conceivable that even during the deposition of the thickest marlstone unit without salt molds Uinta Lake

84 Bradley, W. H., op. cit. (Prof. Paper 158), p. 99.

68 Clarke, F. W., The composition of the river and lake waters of the United States: U. S. Geol. Survey Prof. Paper 135, p. 48, 1924.

${ }_{87}$ Bradley., W. H., op. cit., pp. $91-93$. 
was not partly freshened by overflow. However, it is about equally justifiable to assume that the lake did overflow, for if, as seems wholly possible, the streams carried a greater quantity of dissolved solids, if the average depth of the lake even when full was less than about 50 feet, and if there was a considerable quantity of strong brine left at the beginning of the interval when the thickest barren unit was deposited, then as no salt was deposited it would be necessary to conclude that some of the dissolved solids had discharged from the lake by overflow. The presence of remains of ganoid fish in these barren units favors the hypothesis that the water was freshened.

A quite different interpretation might be placed upon some of the thinner barren units-namely, that they represent areas of the lake bottom which by reason of slight local warping were covered by deeper water from which no salt crystallized. According to this interpretation salt may have formed at the strand line in other parts of the lake basin and so maintained the balance between supply and precipitation.

The section of the Green River formation measured near the Duchesne-Uintah county line a few miles west of Desolation Canyon, Utah, contains no saline faciesa lack which appears to be significant in accounting for the utter dissimilarity between the saline zone of the Indian Canyon section and the saline zones east of Desolation Canyon. Approximately the lower half of the formation near the Duchesne-Uintah county line consists of a sandy facies which the writer regards as a sublacustrine deltaic deposit. This interpretation of the lower part of the formation and the absence of salt in the upper part suggest that a relatively large supply of fresh water continued to come into this part of the lake for most of the rest of Green River time. Detrital material brought in by the stream that furnished this water would tend ultimately to build up a low ridge that in times of low water would isolate the west end of the Uinta Basin. Nevertheless, the greater relative compaction of the predominantly shaly formation on each side of the less compactible sandy deltaic facies was probably a more effective factor in creating a north-south divide across this part of the Uinta Basin. According to this interpretation the saline phases in the western part of the Uinta Basin may have formed independently of those in the eastern part and in the Piceance Creek Basin. This would explain the lack of similarity in mineral composition and in general aspect between the two groups of saline phases.

The saline phases in the eastern part of the Uinta Basin and in the Piceance Creek Basin are less well defined and can not yet be correlated with one another. (See pl. 3.) The salt in these phases formed as radial aggregates and in layers much less closely spaced than the layers that contain glauberite (?) molds. Ellip- soidal cavities whose major axes range from a fraction of an inch to more than 5 feet in length now represent these radial aggregates of the saline mineral.

A few cavities from the beds along the lower part of Piceance Creek contain cellular calcite fillings which preserve as molds the long bladelike salt crystals. (See pl. 6, A.) Unfortunately the crystals were so complexly intergrown that they can not now be identified.

A general climatic change involving a diminution of the average annual rainfall or perhaps increased evaporation due to changes in the seasonal distribution of the rainfall was probably the principal factor controlling the shrinkage of the ancient Uinta Lake and consequently the precipitation of salt. Using as a measure the thickness of the saline facies in Indian Canyon, Utah, about 800 feet, and assuming again that the average rate of accumulation of the rocks in this facies is 1 foot in about 2,000 years makes the length of this interval of reduced precipitation or increased evaporation of the order of $1,500,000$ years. This is about one-fourth of the total length of the Green River epoch according to an estimate based upon the varves in the Green River formation in the vicinity of Parachute Creek, Colo. ${ }^{88}$

The absence of salt and the differences in lithology in that part of the formation above the saline facies seem to indicate a reversion to a somewhat moister climate or a reduction of the evaporation rate, perhaps more nearly comparable to that which prevailed during the earlier stages of Uinta Lake. The absence of salt from these uppermost beds might also be accounted for by either of two alternative hypotheses. If the outlet were cut down so that the area of the lake was materially diminished, the total loss by evaporation from the lake and its drainage area would be diminished, because in general the rate of evaporation from a free water surface is greater than from the land and plants. Thus if the outlet were cut down and the climate remained constant the run-off from the drainage basin might be sufficient to cause intermittent discharge from the lake and so prevent salt deposition. Accession of additional drainage area by stream capture would bring about the same condition of discharge from the lake, even if both the climate and the altitude of the outlet remained unchanged.

\section{SECONDARY MINERALS}

Apparently few changes have occurred in the minerals of the oil shale since the compaction and lithification of the original ooze. Very small quantities of chalcedony were found in some oil-shale beds, and secondary calcite is hardly more plentiful. The secondary calcite occurs as large irregular crystals or as minute spherulites with perfect radial structure.

Bs Bradley, W. H., op. cit. (Prof. Paper 158), p. 107. 


\section{CONCRETIONS}

Calcite coneretions.-Concretions of microgranular calcite are exceedingly abundant in some oil-shale beds and occur at least in small numbers in nearly all the oil-shale beds of the Green River formation. They are ellipsoidal and range in length from 0.25 millimeter to about 2 centimeters. The minor axes average about one-fourth of the major axes. (See pl. 17, A.)

As the beds that are rich in organic matter are so extremely fine grained and compact; it seems very doubtful if solutions could have moved freely enough in them after lithification to produce these calcite concretions. On the contrary, it seems rather probable that the concretions were formed while the ooze was still soft and plastic. Nevertheless, as they have crowded the laminae away from them both above and below, the ooze must have been a stiff enough gel to retain its original laminate structure. The carbonate grains in the smaller of these concretions average about 0.001 millimeter in diameter. This small size suggests that the minute mineral particles migrated and so assembled under the impulsion of the same forces that control the agglomeration of any extremely fine particles. Thus the fine mineral grains, although larger than colloidal particles, may be considered analogous to the dispersed phase of a colloid, and the organic matter may be regarded as the dispersion medium. An active coagulating agent might then have assembled many of these particles, the larger aggregates growing at the expense of the smaller ones, which by reason of their greater convexity would have been unstable in the presence of the larger aggregates.

Chert concretions.-Concretions of chalcedonic quartz are not particularly common but were found in several oil-shale beds, some of which are of rather low grade. These concretions like those of calcite; are roughly ellipsoidal. They range in length from about 5 millimeters to 5 centimeters. These concretions also displace the laminae of the oil shale, but they must have formed immediately upon the burial of the sediments, for they contain beautifully preserved organic structures, fern sporangia and spores, various pollens, algae, and fragments of the tissues of higher plants. (See pl. 23, figs. 5, 8, 10, 12.) Apparently these organisms together with other organic matter were suspended in a mixture of organic and silica gels. The parts of organisms were thus perfectly embalmed, though their original composition has doubtless been altered. Yet in that alteration and despite the crystallization of the silica the organisms were not at all crushed, distorted, or cracked by shrinkage.

These chert concretions are unusual in another feature. Each contains a peripheral layer of pyrite, which is in cubes, octahedra, acicular crystals, and minute spheroidal grains. The pyrite also must have been suspended in the mixture of organic and silica gels, as is shown by its excellent crystal form and with particularly convincing force by the bundles of acicular crystals. No satisfactory explanation can yet be offered to account for the segregation of the pyrite in peripheral zones of the concretions.

\section{MICROFOSSILS}

\section{PREVIOUS SIMILAR STUDIES}

Microorganisms, including algae, fungi, Protozoa, and bacteria, from oil shales and bogheads in many parts of the world have been described. The writer believes that the first to recognize and describe such fossil gelosic algae were Bertrand and Renault, ${ }^{89}$ who as long ago as 1892 pointed out that the boghead of Autun, France, consisted chiefly of the thalli of a simple colonial alga, to which they gave the name Pila bibractensis. This work was followed by a noteworthy series of publications by the same authors. ${ }^{90}$ The most remarkable of these papers are the two large systematic works, one by Renault $(1899,1900)$ and the other by Bertrand (1898).

Potoniés report ${ }^{91}$ on his study of the recent sapropels or organic oozes appeared in 1908. 'It is particularly valuable for the light it sheds upon the conditions governing the accumulation of sapropel and the stages of putrefaction which the material passes through.

Zalessky ${ }^{92}$ has commented on the genus Pila and the sapropel of Lake Balkash, which consists chiefly of Botryococcus braunii. In later papers ${ }^{93}$ he described some-very ancient blue-green algae in the Esthonian boghead and another species of Pila in a deposit near Tcheremkhova, Russia.

Davis, ${ }^{94}$ in a preliminary paper, reported finding wellpreserved blue-green and green algae and unclassified algae in the oil shale of the Green River formation. Of the blue-green algae he mentioned specifically one which he regarded as Spirulina sp. His photograph of this organism is reproduced in Plate 19, Figure 10, and the writer's description, together with some com-

Bertrand, C. E., and Renault, B., Pila bibractensis et lo boghead d'Autun : Soc. hist. nat. Autun Ball., vol. 6, pp. 159-253, 1892.

90 Renault, B., Reinschia australis et premières remarques sur le kerosene shalo de la Nourelle-Galles du Sud: Soc. hist nat. Autun Bull, vol. 6, pp. 321-425, 1893; Sur quelques microorganismes des combustibles fossiles: Soc. ind. min. St.-ftienne Bull., 3d ser., vol. 13, pp. 865-1169, 1899; vol. 14, pp. 1-150, 66 figs., 30 pls., 1900. Bertrand, C. E., Nouvelles remarques sur le kerosene shale de la Nouvelle-Galles du Sud: Soc. hist. nat. Autun Bull., vol. 9, pp. 193-292, 1896; Les charbons humiques et les charbons de purins: Univ. Lille Trav. et móm., vol. 6, Mém. 21, 214 pp.; 1898.

91 Potonié, H., Die rezenten Kaustobiolithe und ihre Lagerstatten: K. preuss. geol. Landesanstalt Abh., new ser., Heft 55, Band 1, pp. 3-35, 59-238, 1908.

92 Zalessky, M. D., On the nature of Pila or the yellow bodies of boghead and on sapropel of the Ala-Kool Gulf of the Lake Balkash: Com. geol. Bull., vol. 33, pp. 495-507, Petrograd, 1914 .

${ }^{93}$ Zalessky, M. D., Sur le sapropelite de l'âge silurien forme par une algue cyanophycée: Soc. paléont. Russie Annuaire, vol. 1, pp. 25-42, 1916; Sur quelques sapropelites fossiles: Soc. géol. France Bull., 4th ser., vol. 17, pp. 373-379, 1917.

94 Davis, C. A., On the fossil algae of the petroleum-ylelding shales of the Green River formation of Colorado and Utah: Nat. Acad. Sci. Proc., vol. 2, pp. 114-110, 1916. 
ments, is given on page 42. Davis also mentioned a green alga which he thought should be referred to Pediastrum or a closely related genus. His photograph of this is reproduced as Plate 21, Figure 5, of this report, and the writer's description and reasons for transferring to another genus are given on page 43 . In addition to these algae he referred to another green alga which had spiral chloroplasts and which he - regarded as either a prototype of Spirogyra or perhaps even a species of that genus. Unfortunately no photograph of this remarkable fossil was found among Davis's photomicrographs, and the writer has never discovered anything comparable to it in his own thin sections or those made by Davis. So far as the writer is aware Davis's mention is the only record of chloroplasts in fossil algae from the Green River formation.

Some brief notes made by Davis were published in Winchester's latest bulletin on oil shale. ${ }^{95}$ They are reproduced here, as they are particularly pertinent to this study.

\section{Flora of the oil shale of the Green River formation}

[Notes by C. A. Davis, March 30, 1915]

Bacteria: Crenothrix and similar low filamentous types. Myxophyceae: Blue-green algae.

Algae:

Protococcaceae: Protococcus pediastrum.

Conjugate: Spirogyra.

Fungi: Saprophytic molds, etc.

Mosses: Spores probably from these plants.

Pteridophyta: Ferns; annuli from fern sporangia.

Spermatophyta:

Gymnospermae: Pinaceae: Pollen of Picea and Pinus.

Angiospermae: Pollen and fragments of cells, tissues, etc. Bark cells and residues, small pieces, poorly preserved. In addition there are abundant and well-preserved remains of good size and of frequent occurrence, which seem to be structureless so far as cellular structures are concerned. However, they have definite and pretty regular forms and, in Dictyonophora, definite areas which carry well-marked and characteristic patterns which seem like cells but which show no cell walls. These anomalous forms seem to have been the most abundant organisms in the waters in which the shales were laid down and are evidently vegetables of a low order of development. They are manifestly in place as they grew, for they do not show in pressed-down masses but were buried in natural positions, very slowly.

White and Stadnichenko, ${ }^{\theta 6}$ in a recently published paper, describe some fucoid algae and spore exines and their chemical compositions.

The writer ${ }^{97}$ in 1924 described a new species of Epipolaia. The genotype of this alga was described by Bertrand ${ }^{98}$ and came from the Brown oil shale of Broxburn, Scotland.

${ }^{96}$ Winchester, D. E., Oil shale of the Rocky Mountain region: U. S. Geol. Survey Bull. 729 , p. $32,1923$.

White, David, and Stadnichenko, Taisia, Some mother plants of petroleum $n$ the Devonian black shales: Econ. Geology, vol. 18, pp. 238-252, 1923.

${ }_{97}$ Bradley, W. H., An oil shale and its microorganisms from the Fuson formation of Wyoming: Am. Jour. Sci., 5th ser., vol. 8, pp. 228-234, 1924.

98 Bertrand, C. E., Les charbons humiques et les charbons de purins: Univ. Lille Trans. et mém., vol. 6, Mém. 21, pp. 179-181, 1898.
Thiessen's study of coorongite ${ }^{p 9}$ demonstrated in a most satisfactory manner the algal origin of boghead corls. Coorongite consists of the gummified thalli of a modern alga whose systematic position is unknown but which be called Elaeophyton coorongiana. These planktonic algae live in salt lakes and lagoons in South Australia. During the summer the lakes dry up and the accumulations of algae quickly dry into sheets of rubber-like dark-biown material. The similarity, even in the minutest details, of Elaeophyton to the fossil colonial algae in many bogheads is most convincing.

White ${ }^{1}$ has recently given a comprehensive and concise summary of the work which has thus far been done on the sapropelic deposits. This summary he enriches with information from his own studies. He treats in particular the oil shale of the Green River formation and presents his conclusions regarding its origin together with some of the evidence upon which they are based.

The writer in a recent paper ${ }^{2}$ gave the descriptions of four of the algae described herein (pl. 21, figs. 3, 6, $7 ;$ pl. 22, fig. 1), together with a brief discussion of factors that have probably contributed to their excellent preservation. This paper was writted in response to Potonié's recently published assertion ${ }^{3}$ that the socalled fossil algae from certain boghead coals and oil shales were never organisms but instead structures resulting from the coagulation of certain colloidal constituents of the original organic ooze. In order to get some of these fossils before botanists eight of the algae described in this report (pl. 19, figs. 7, 8; pl. 21, figs. $1,3,5,6,7$; pl. 22 , fig. 1 ) were described in another recent paper ${ }^{4}$ together with some brief notes on the manner of their preservation.

\section{PREPARATION OF THIN SECTIONS}

Many thin sections of the oil shale were ground in the ordinary manner in the petrographic laboratory of the Geological Survey. However, heat was avoided as much as possible, and to this end the sections were mounted in a mixture of canada balsam and xylol. This mixture was thin enough to flow readily at room temperature. Small weights supported on cork disks were placed upon the cover glasses for several days, as otherwise the sections would have been badly wrinkled after a few months. Moreover, in most unpressed sections the distance between the section and the upper surface of the cover glass is so great that an immersion objective can not be used. A few grades

98 Thiessen, Reinhardt, Origin of the boglfead coals: U. \$. Geol. Survey Prof. Paper 132, pp. 126-135, 1925.

1 White, David, The carbonaceous sediments, in Twenhofel, W. H., Treatise on sedimentation, pp. 289-304, 1926.

- Bradiey, W. H., Neue Beobachtung über Algen als Urmaterialen der Bogheadkohlen und Schiefer: Centralbl. Mineralogie, Abt. B, No. 5, pp. 182-190, 1929.

'Potonie, R., Einführung in die allgemeine Kohlenpetrographie, pp. 181-140, Berlin, 1924. Potonié, R., and Hellmars, H., Zur Entstehung der Gerrinungsköroer (der sogenannten Algen) der Bogheadkohlen und Schiefer: Preuss. geol. Landesanstalt Jahrb., vol. 48, pp. 152-157, 1926.

4 Bradley, W. H., Fresh-water algae from the Green River formation of Colorado: Torrey Bot. Club Bull., vol. 56, pp. 421-428, 1929 . 
of oil shale may be so rich that it is advisable to avoid even the heat necessary to cement the chip to the glass slide: These may be cemented with and mounted in sodium silicate, which, however, is an unsatisfactory mounting medium because it does not clear the specimen enough, because bubbles are almost sure to develop, and because after a few years ib crystallizes.

Oil shale, especially the richer grades; can be softened and cut in a microtome. These sections are very satisfactory, particularly for study of the microorganisms and pollens, because all the mineral grains that transmit and diffuse the light have been removed. In preparing the oil shale for microtome sectioning the writer has followed essentially the method outlined by Jeffrey ${ }^{5}$ except that the treated shale is embedded in paraffin instead of celloidin. The use of paraffin not only eliminates the long, tedious process of the celloidin embedding but also makes it possible with a rotary microtome to cut good ribbons of sections as thin as 6 microns ( 0.006 millimeter).

So far as the writer is aware C. A. Davis left no notes describing his technique of preparing microtome sections. However, on some small specimen bottles in which he treated the shale are a few fragmentary notations from which it is clear that he used dilute nitric acid, potassium hydroxide, pyridine, phenol, and chloral hydrate as softening agents and hydrofluoric acid to remove the mineral matter. What the order of procedure was is unknown. He used paraffin as an embedding medium.

The writer's method of treatment is outlined here briefly. The fresh shale is cut with a hack saw into rectangular blocks 5 or 6 millimeters square and 3 or 4 millimeters thick, so oriented that the square surfaces are parallel to the bedding. These pieces are treated with equal parts of hydrofluoric acid and dilute nitric acid (1-1) at room temperature for about a week, or longer if the shale is obviously rich in pyrite. The excess acids are washed out with running water, and the shale is then soaked for several days in a very dilute sodium hydroxide solution to neutralize the acid remaining in the specimens. If any of the nitric acid remains the shale will be dissolved rapidly in the hot phenol. After thorough rinsing the shale blocks are then immersed in melted phenol, where they are kept at about $70^{\circ} \mathrm{C}$. until soft enough to be penetrated easily with a fine needle. The time required for this softening varies greatly, but roughly it bears an inverse ratio to the richness of the shale. The time necessary to soften various sorts of shale from the Green River formation ranged from three days to as many months. All kinds swell more or less in the softening process, and some warp and crack badly. From the phenol the shale is transferred to hot water, in which it remains for

\footnotetext{
seftrey, I. C., Methods of studying coal: Science Conspectus, vol. 6, pp. 71-76,
} 1916. several days. The hot water must, of course, be changed frequently. When entirely free of phenol the shale is dehydrated in strong alcohol and finally with three changes of absolute alcohol. From the absolute alcohol it is transferred to a mixture of equal parts of xylol and absolute alcohol. After about one hour in the xylol and alcohol it can be transferred to warm paraffin dissolved in xylol, and from that into pure melted paraffin, in which it should soak for at least 24 hours, but to leave it 48 hours is safer. The oil shale can then be cut with a sliding or rotary microtome. Serial sections so cut are valuable for making counts of the microorganisms or pollens and spores. Although some shale can be cut as thin as 5 microns, there is no advantage in such thin sections. Ordinarily sections 12 to 15 microns thick are satisfactory. The material is so translucent that sections as much as 150 microns thick can be studied easily under the microscope. These very thick sections are necessary to get complete individuals of the larger microfossils, such as some of the insects. The microtome sections are mounted in a mixture of Canada balsam and xylol, and the cover glasses are weightedlin the same way as for the ground sections.

\section{APPEARANCE OF ORGANIC MATTER IN THIN SECTIONS}

Two kinds of organic matter can be clearly distinguished in thin sections of oil shale. One is entirely structureless, translucent, and lemon-yellow to reddish brown. It makes up the groundmass of the shale and contains various quantities of finely divided mineral matter, which in many shales is segregated in more or less well-defined laminae. The other kind of organic matter consists of complete or fragmentary organisms such as algae, Protozoa, and insects and parts of higher plants-spores, pollen grains, or minute pieces of tissue. For the sake of brevity all this material that has definite form will here be designated "figured material:" In this sense "figured" implies nothing in the way. of illustrations. All the figured material is embedded in the structureless component and in addition to having definite form may even show internal structure. (See pl. 18.)

Structureless material exceeds the figured material in all thin sections of oil shale from the Green River formation which the writer has examined. Hence the microscopic aspect of this shale is very unlike that of pure alga bogheads-for example, the kerosene shale of New South Wales, which consists almost exclusively of well-preserved colonial algae. Nevertheless all thin sections of rich Green River oil shale contain some figured material, and a few contain considerable quantities. Relatively little of the figured material is well enough preserved to be identified and described, but in certain beds microfossils are fairly common. This fact explains why so many of the microorganisms described below came from only a few localities. 
The entire area of each thin section containing microfossils was searched systematically at a magnification of about 250 diameters. Objects to be studied more critically were located and recorded by means of the coordinates of the mechanical stage.

The writer tried several stains on the microtome sections but was wholly unsuccessful. The organic matter is evidently too inert and dense to react to them.

\section{FLORA OF THE OIL SHALE}

BACTERIA

Plate 19, Figures 1, 4

Davis ${ }^{6}$ reported Crenothrix, but none of his photomicrographs show filaments with internal structure definite enough to convince the writer that they should be referred to that genus. Yet several thin sections show an abundance of minute filaments 1 to 5 microns in diameter which are probably trichobacteria. (See pl. 19, fig. 4.) None of them show vegetative cells or gonidia, however, and so they can not be surely distinguished from some of the simplest Cyanophyceae, whose structure is nearly identical. Their unusual length and abundance favor the assumption that they are bacteria which lived within the organic ooze rather than algae, for most of the algae in the oil shale are fragmentary.

A few bacilli (?) occur in the richest beds, but they are so rare that it does not seem worth while to name them. The largest one shown near the center of figure 1, Plate 19, is about 1 micron in diameter and 20 microns long. It is constricted near one end, just below a beadlike termination. This cell resembles somewhat the large cells of Bacillus subtilis, some of which are 1 micron in diameter and as much as 17 microns long. ${ }^{7}$

Locality: Both the filamentous bacteria(?) and the bacilli(?) occur in a sample collected by $\mathrm{E}$. G. Woodruff from Asphalt Tunnel, about 2,300 feet above the base of the formation, in sec. 1, T. 7 S., R. 98 W., Garfield County, Colo.

Cocoid bacteria have not been found in the oil shale of the Green River formation. This seems rather strange, for they are exceedingly abundant in the Miocene oil shale from Elko, Nev., and the writer ${ }^{8}$ showed that they were plentiful in the oil shale of the Fuson formation. In neither of these oil shales is the organic matter so much disintegrated by microbian decomposition as that in the Green River oil shale.

\section{FUNGI}

Spores of fungi are more or less plentiful in most thin sections of the oil shale. Conidia and

\footnotetext{
6 Davis, C. A., notes cited by Winchester, D. E., Oil shale of the Rocky Mountain region: U. S. Geol. Survey Bull. 729, p. 32, 1923.

"Löhnis, F., Studies upon the life cycles of the bacteria: Nat. Acad. Sci. Mem. vol. 16, pl. 23, 1921.

8 Bradley, W. H., An oil shale and its microorganisms from the Fuson formation of Wyoming: Am. Jour. Sci., 5th ser., vol, 8, p. 242, fig. 4, 1924.
}

fragments of hyphae were also found, and locally they are numerous. : The following notes on the fungi spores are based very largely on suggestions made by Dr. C. L. Shear, ${ }^{9}$ of the Bureau of Plant Industry.

Plate 19, Figure 2.-The rigid epispore, together with its fusiform shape and symmetrical septation, strongly suggests that this is a spore belonging to Leptosphaeria or a closely related genus. Species of Leptosphaeria are common parasites, have a wide geographic distribution, and thrive in all climates.

Plate 19, Figure 3.-The general form and apparent hyaline terminal compartments, coupled with the thick epispore and thicker septa, suggest that this is probably a spore of a species of Pestalozzia with the filiform terminal appendages lacking.

Plate 19, Figure 5.-Apparently there are two elongate multiseptate spores here. These resemble the spores of the hyphomycete Septonema.

Plate 19, Figure 6.-This group of spores may represent an ascospore group, although there are apparently only seven spores. More probably, however, it is a chain of conidia similar to those of the genus Bispora.

Plate 20, Figure 1.-If these are conidia they may belong to a genus like Trichothecium; if they are ascospores they may belong to a genus like Mycosphaerella or Didymella, many species of which have similar unequally divided spores.

Plate 20, Figure 2.-This is evidently a chain of conidia similar to those produced in various genera of Hyphomycetes, such as Aspergillus and Haplographium.

Plate 20, Figure 3.-This small spore suggests the spores of Helminthosporium sp.

Plate 20, Figure 4.-This is probably a germinating spore. It suggests Hendersonia sp.

Plate 20, Figure 5.-These appear to be chains of conidia and may belong to a genus like Torula.

Plate 20, Figure 6.-This group suggests a hyphomycete with sporophores and detached uniseptate conidia. It somewhat resembles Cladosporium sp.

Plate 20, Figure 7.-These thick-walled spores resemble rather closely those of Macrosporium sp.

Plate 20, Figure 8.-This resembles a rust sorus and suggests the sorus of Uromyces sp. with spores.

Plate 20, Figure 9.-This slightly broken form is very similar to the conidia of Brachysporium sp.

\section{ALGAE}

The algae found in the oil shale are all microscopic, and although their outlines are remarkably well preserved their internal structural features, such as chloroplasts, nuclei, vacuoles, and pyrenoids, have disappeared except possibly in a fragment of Spirogyra in which Davis reported having found the chloroplasts. Other features have likewise disappeared,

Personal communication, March, 1927. 
such as the gelatinous sheaths that very likely inclosed some of the Cyanophyceae. Moreover, in none of the fossil algae has the writer been able to establish to his own satisfaction the mode of reproduction, despite the statement of Davis 10 that "many of them show a series of reproductive stages so characteristic as to fully establish their taxonomic relationships." Of course, their color has not been preserved, and therefore the writer's assignments to genera of living algae are based wholly on their external forms. Yet these are all simple and distinctive forms, and for that reason the writer feels that these assignments are probably not greatly at variance with the truth. Some of the algae are too uncertain to warrant assignment to even a tentative position in the natural system, but the similarity of some of these two living forms is pointed out. A few, on the other hand, are unique so far as the writer has been able to determine. One of the most unusual of these, Eoglobella longipes, is described in this report.

\section{Class FuagelLata \\ Order EUGLEIIDA \\ Family EUGLENINEAE \\ Genus PHACUS Dujardin \\ Phacus sp. cr. P. caudata Hubner \\ Plate 19, Figure 7}

Phacus sp. cf. $P$. caudata Hübner. Bradley, Torrey Bot. Club Bull., vol. 56, pp. 423-424, 1929.

This pyriform cell is-remarkably like certain species of the euglenoid genus Phacus. In the short, straight caudal spine, the asymmetry of the forward end, and the dimensions it is very close to $P$. caudata Hübner, which, according to Pascher, ${ }^{11}$ is 2.5 microns wide and 45 microns long. The fossil is about 25 microns wide and 46 microns long. However, no longitudinal striae and no longitudinal fold are discernible, though these characters may have been obscured during compaction and lithification of the organic ooze in which the organism was embedded. The fossil is also very nearly like Lepocincles teres Schmitz, especially in the shape and length of the spine, but this living species is symmetrical. Pascher ${ }^{12}$ gives the dimensions of $L$. teres as 41 microns long and 17 microns across. This fossil is remarkable in that it apparently represents the preservation of a naked protoplast. In commenting upon this unusual fossil Professor Smith ${ }^{13}$ called the writer's attention to a central light dot in just the position of the pyrenoid of Phacus. Examination under polarized light shows that this dot is due to the presence of a minute mineral grain which only by chance happens to occupy the position of the pyrenoid.

\footnotetext{
10 Davis, C. A., On the fossil algae of the petroleum-yielding shales of the Green River formation of Colorado and Utah: Nat. Acad. Sci. Proc., vol. 2, p. 116, 1916.

11 Pascher, A., Die Süsswasserflora Deutschlands, Österreichs und der Schweiz, Heft 2, p. 138, 1913.

12 Idem, p. 135.

13 Snith, G. M. (Stanford University), personal communication.
}

\author{
Class CYATOPBYCEAE \\ Order CHROOCOCCALES \\ Family CHROOCOCCACRAE \\ Genus CHROOCOCCUS IIägeli \\ Plate 19, Figure 8
}

Chroococcus? sp. cr. C. westil (w. West) P. Boye

Chroococcus sp. cf. C. westii (W. West) P. Boye. Bradley, Torrey Bot. Club Bull., vol. 56, pp. 422-423, 1929.

Each specimen of this fossil alga consists of a pair of broadly ovate semicells that range from 12 to 18.5 microns in diameter. The cell walls are thick and homogeneous. Sheaths are apparently absent, though originally they may have been present and have merely contracted and merged with the cell wall, thus making it appear somewhat thicker. In shape and size these cells agree very well with the living $C$. westii. Accord. ing to Pascher ${ }^{14}$ the cells of $C$. westii, without the sheaths, range from 13 to 27 microns in diameter.

The microflora of the Green River oil shale contains more individuals of this species than of any other. The writer calculated that in the sample of oil shale in which the specimen illustrated was found there are about 5,700 individuals to the cubic centimeter. This calculation depends upon the assumption that the fossils are as numerous in other parts of the shale as that from which the thin sections were cut and is obviously subject to a very large possible error, but the result is probably of the right order of magnitude. Volumetrically these algae are negligible, but their numbers indicate in a rough way the composition and aspect of the microflora.

Occurrence: The specimen illustrated was found in a sample of pyritiferous oil shale that yielded 44 gallons of oil to the ton. The sample was collected by D. E. Winchester from a bed of black thin-bedded oil shale in the Oil Shale Mining Co.'s quarry in sec. 27, T. 7 S., R. 100 W., Garfield County, Colo. This species was also found in samples of oil shale from other parts of Garfield County (sec. 1, T. 7 S., R. 98 W.; Monarch Shale Oil Co.'s mine, sec. 32, T. 6 S., R. 97 W., and sec. 25, T. 5 S., R. 95 W.), from Rio Blanco County, Colo. (sec. 25 , T. 1 N., R. 95 W.), and from Utah (sec. 6, T. 11 S., R. 24 E.).

Chroococeus? sp. or. C. dispersus (Von Kelssier) Lemmerman

$$
\text { Plate 19, Figure } 9
$$

This small group of tightly packed spherical cells is referred to Chroococcus with considerable hesitation. Of the species in this genus it comes nearest to $C$. dispersus, but its cells, which are about 6.5 microns in diameter, are a little larger and more tightly appressed. The cells of $C$. dispersus without their investments are 3 to 4 microns in diameter. The fossil might almost as well be referred to Microcystis, as in habit and cell size it is comparable with $M$. flos-aquae (Wittrock) Kirchner.

14 Pascher, A., op. cit., Heft 12, p. 78, flg. 70, 1925. 
Occurrence: The specimen illustrated was found in a sample collected by E. G. Woodruff from Asphalt Tunnel, about 2,300 feet above the base of the formation, in sec. 1, T. 7 S., R. 98 W., Garfield County, Colo. These algae also occur in small nodules of black pyritiferous chert from a bed of hard carbonaceous ostracode shale about 140 feet above the base of the formation in sec. 22 , T. 11 S., R. 10 E., Duchesne County, Utah.

\section{Order HORMOGONEAE \\ Family OSCMLIATORIACEAE \\ Genus CRINALITU Crow Crinallum? sp. \\ Plate 19, Figure 10}

Spirulina sp. Davis, Nat. Acad. Sci. Proc., vol. 2, p. 116, 1916.

The trichomes of this alga are a little less than 3 microns in diameter, duplex, and joined at the ends so that if untwisted they would apparently make a complete ring. As they have been flattened during compaction of the rock it is impossible to tell whether they were originally circular in cross section or flat and straplike. However, they apparently are not septate, though the numerous transverse shrinkage cracks now give that impression. The filaments form an ellipse about 60 microns long and 32 microns wide. In all these characters the fossil is remarkably like Spirulina duplex Wolle, but Wolle's species has not been generally accepted as valid. Recently Crow ${ }^{15}$ found an alga that agrees in many ways with Wolle's species but differs from it in having a sheath and in being $U$-shaped rather than closed as a complete ring.

The fossil alga described here seems to belong rather to Crinalium than to Spirulina, as Davis thought.

Occurrence: In a sample of oil shale collected by E. G. Woodruff from Asphalt Tunnel, about 2,300 feet above the base of the formation, in sec. 1, T. $7 \mathrm{~S}$., R. 98 W., Garfield County, Colo.

\section{Genus CRINaLruM Crow \\ Crinallum? sp. cr. C. endophyticum Crow \\ Plate 21, Figure 1}

Crinalium? sp. ef. C. endophyticum Crow. Bradley, Torrey Bot. Club Bull., vol. 56, p. 423, 1929.

These strap-shaped filaments are much like those of Crow's genus Crinalium. They are duplex, slightly twisted, and without apparent transverse septae. Moreover, some of them are sharply bent in the middle though none are really U-shaped. They differ from $C$. endophyticum in that they are nearly 7 microns broad, whereas the filaments of the living species are 3 to 4 microns in diameter. Like other fossil algae of this microflora they have no discernible sheath, and it is impossible to tell if there ever was one. Filaments like these are common in the oil shale, and all are much

\footnotetext{
1s Crow, W. B., Crinalium, a new genus of Cyanophyceae, and its bearing on the
} morphology of the group: Annals of Botany, vol. 41, No. 161, pp. 161-165, 1927. broken by shrinkage cracks. Their dark reddishbrown color is also a constant feature and seems to indicate that they are rather strongly bituminized."

Occurrence: In a sample of oil shale collected by E. G. Woodruff from Asphalt Tunnel; about 2,300 feet above the base of the formation, in sec. 1, T. $7 \mathrm{~S}$, R. 98 W., Garfield County; Colo.

\section{Family STTGOREMatackaR \\ Genus HAPALOSIPHON Fügeli \\ Hapalosiphon sp. cr. H. confervaceus Borzi \\ Plate 21, Figures 2, 3}

Hapalosiphon sp. cf. H. confervaceus Borzi. Bradley, Centralbl. Mineralogie, Abt. B, No. 5, pp. 184-185, 1929; Torrey Bot. Club Bull., vol. 56, p. 423, 1929.

This alga is remarkably suggestive of certain living species of Hapalosiphon, yet it does not agree exactly with any of them. It comes closest to $H$. confervaceus Borzi but differs in being slightly smaller and in not having its filaments coated with small grains of calcium carbonate, as described by Pascher. ${ }^{18}$ The trichomes of $H$. confervaceus range from 15 to 22 microns in diameter, whereas those of the fossil range fron 11 to 13 . microns. Moreover, no sheath is discernible in the fossil alga, and whether it ever had one is impossible to tell. The fossil also resembles $H$. aureus W. and G. S. West, but it is more richly branched, and the branches are of about the same size as the principal filament rather than smaller. $H$. flexuosus Borzi has all the characters of the fossil but is corrsiderably smaller. Its trichomes average 6 to 8 microns in diameter.

Occurrence: In a sample of oil shale collected by E. G. Woodruff from Asphalt Tunnel, about 2,300 feet above the base of the formation, in sec. 1, T. $7 \mathrm{~S} ., \mathrm{R}$. 98 W., Garfield County, Colo.

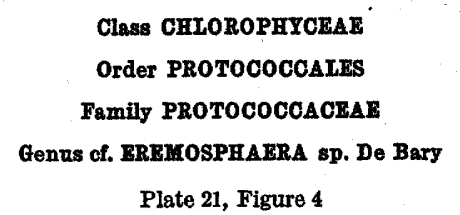

These large spherical unicellular algae seem to be members of the Protococcaceae, but as their chromatophores, pyrenoids, and mode of reproduction are unknown they can not be placed in any existing genus. Eremosphaera viridis De Bary is the only living member of this family comparable in cell size with these fossils. According to Pascher ${ }^{17}$ G. T. Moore's variety minor has cells that range from 30 to 50 microns in diameter. The fossil cells range from about 39 to about 65 microns in diameter. Moreover, the cell walls of the fossils are thin and smooth, like those of $E$. viridis. Botrydiopsis Borzi is another member of this family whose cell shape is like that of the fossil, but even the largest 
U. S, GEOLOGICAL SURVEY
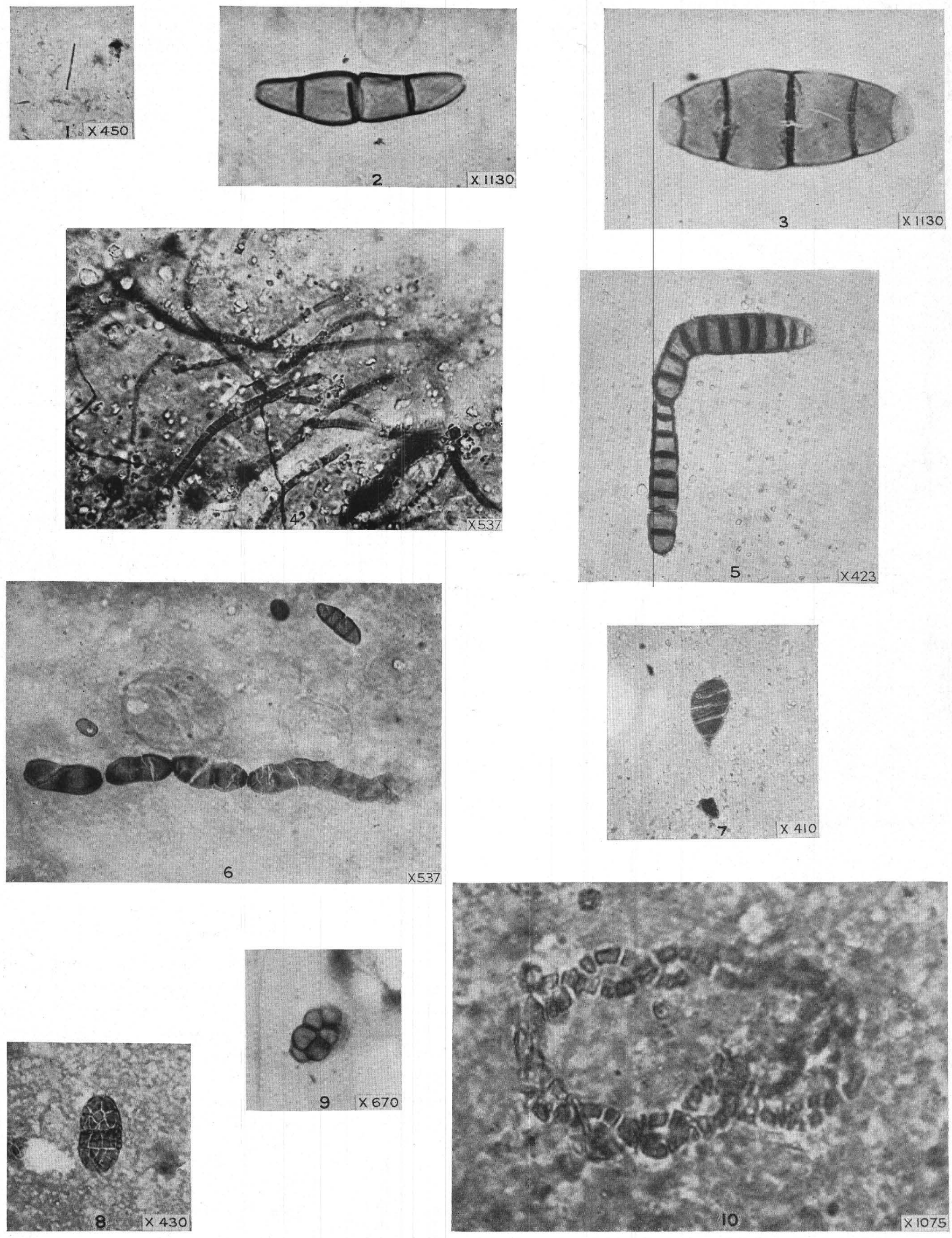

MICROFOSSILS OF THE OIL SHALE OF THE GREEN RIVER FORMATION

1. Large bacillus?
2. Ascospore of Leptosphaeria sp.?

3. Spore of Pestalozzia sp.?

5. Spores resembling those of Septonema.
PROFESSIONAL PAPER 168 PLATE 19
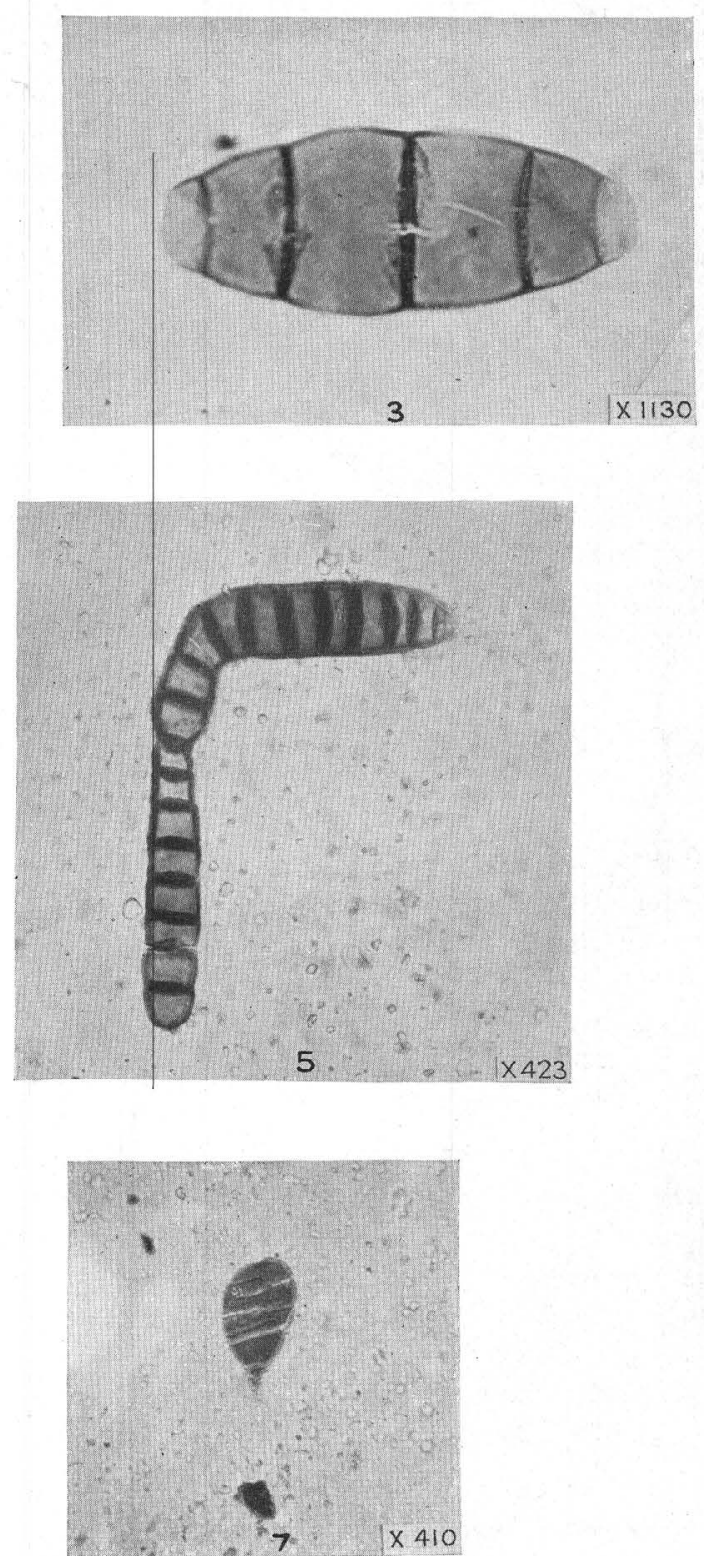

6. Chain of conidia? similar to those of Bispora.

7. Phacus sp. cf. P. caudata Hübner.

8. Chroococcus? sp. ce. C. westii (W. West) P. Boye

10. Chroococcus? spalium? sp. 
U. S. GEOLOGICAL SURVEY
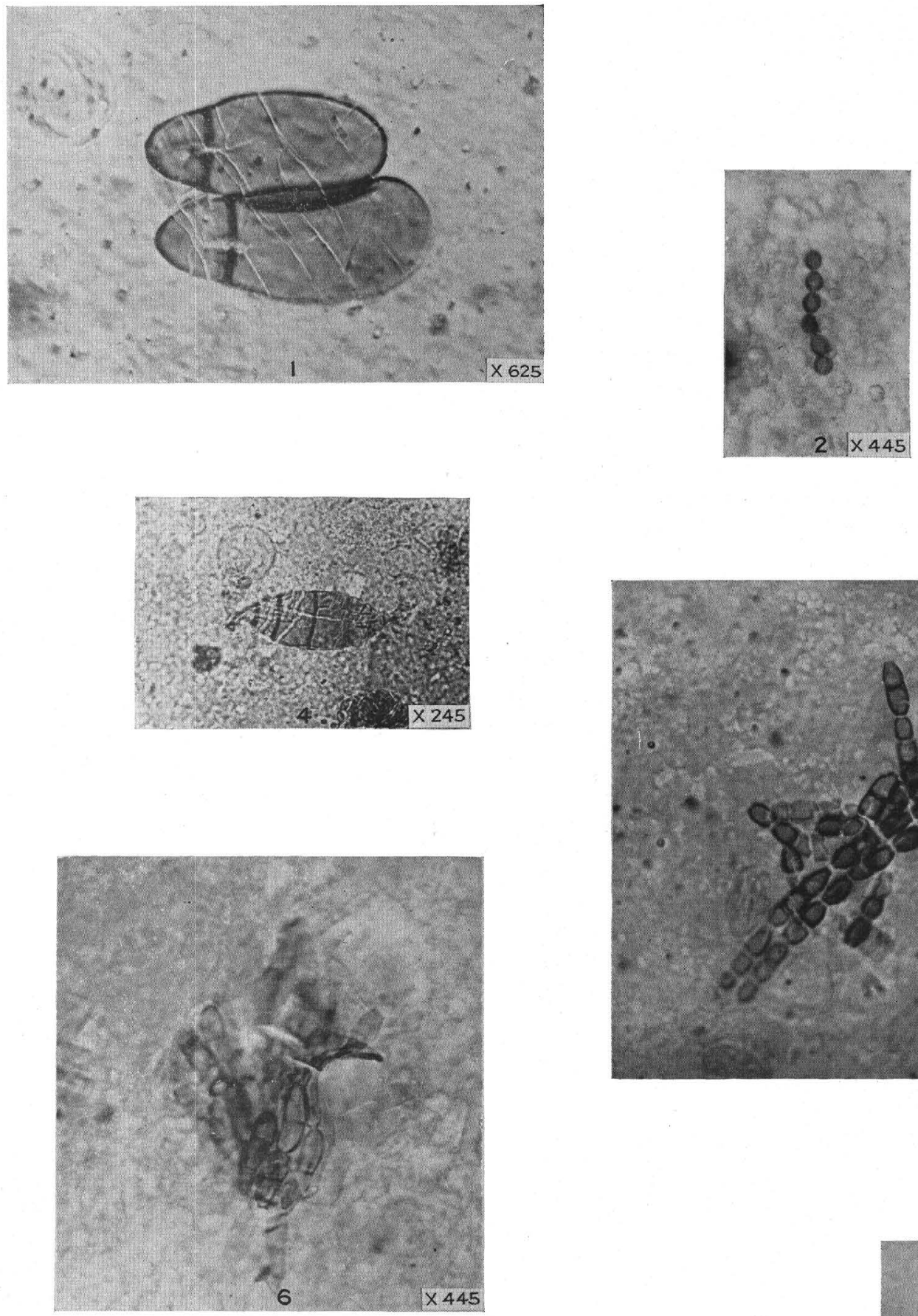

PROFESSIONAL PAPER 168

PLATE 20


MICROFOSSILS OF THE OIL SHALE OF THE GREEN RIVER FORMATION

1. Spores resembling those of Trichothecium, Mycosphaerella, and Didymella. 2. Chain of conidia resembling those of several genera of Hyphomycetes.

3. Spores resembling those of Helminthosporium.

5. Chains of conidia suggesting those of Torula

6. Conidia and sporophores resembling Cladosporium sp.

7. Spore similar to the conidia of Brachysporium sp.

8. Group of spores suggesting sorus of Uromyces sp.
9. Spores resembling those of Macrosporium sp. 



MICROFOSSILS OF THE OIL SHALE OF THE GREEN RIVER FORMATION

1. Crinalium? sp. cf. C. endophyticum Crow.

4. A member of the Protococcaceae, cf. Eremosphaera De Bary.
5. Coelastrum? sp. ef. C. verrucosum Reinsch.

6. Tetraedron sp. ef. T. regulare var. torsum (Turner) B
\%. Microspora sp. cf. M. pachyderma (Wille) Lagerheim. 
U. S. GEOLOGICAL SURVEY
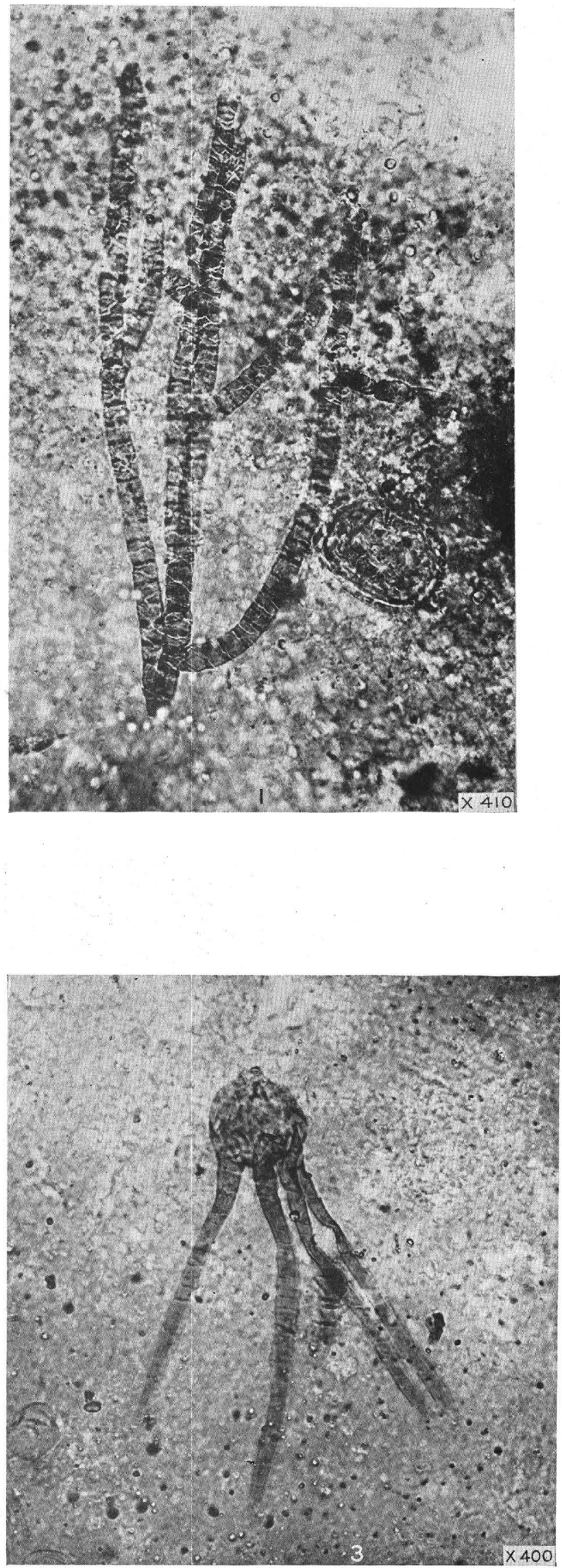

PROFESSIONAL PAPER 168 PLATE 22
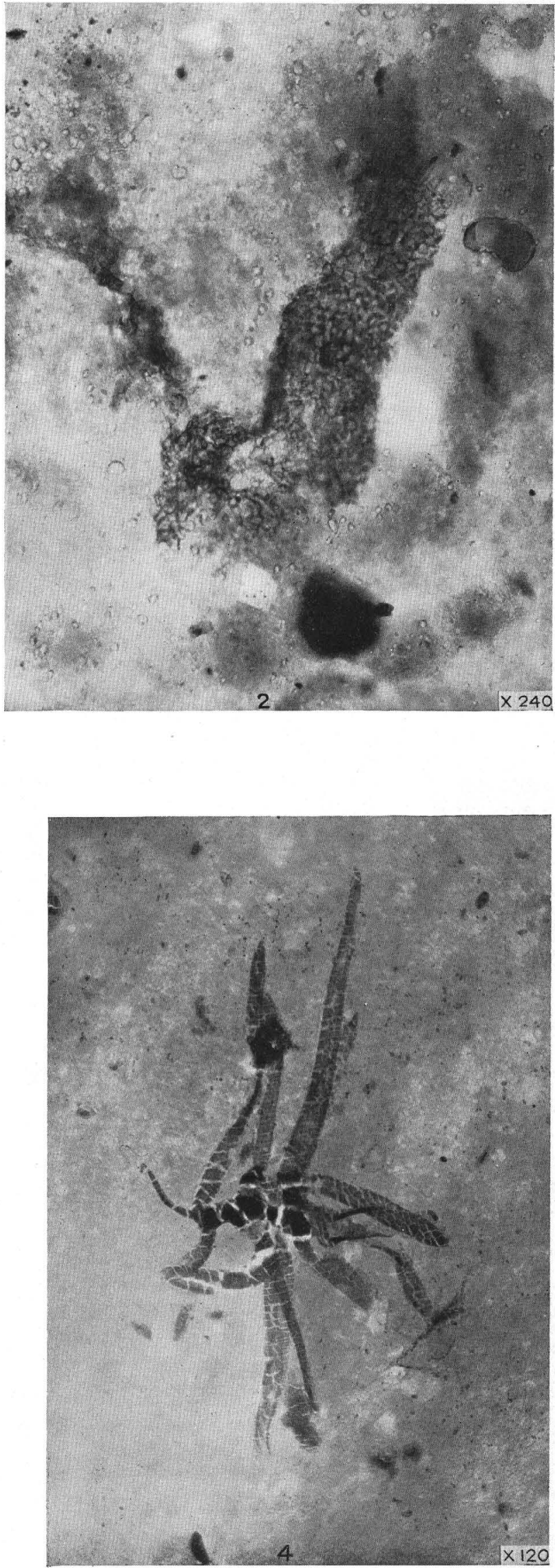

$\times 120$

MICROFOSSILS OF THE OIL SHALE OF THE GREEN RIVER FORMATION

1. Stigeoclonium? sp. cf. S. lubricum (Dillwyn) Kützing. 2. Alga, probably one of the Chroococeaceae.
3. Eoglobella longipes Bradley, n. gen. and sp.
4. Alga with some of the vegetative characters of the Siphonales. 

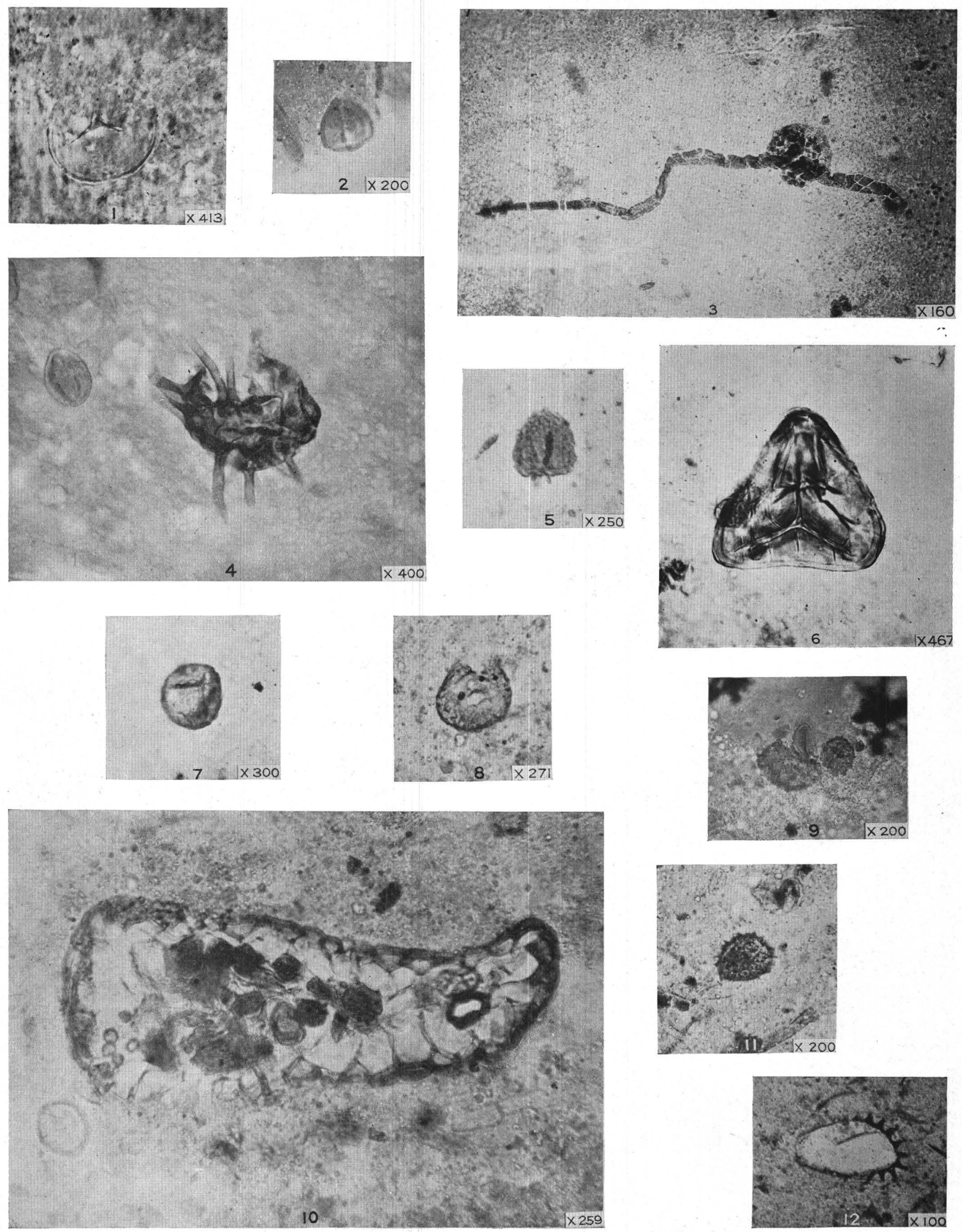

MICROFOSSILS OF THE OIL SHALE OF THE GREEN RIVER FORMATION

$\mathbf{1}, \mathbf{2}, \mathbf{5}, \boldsymbol{7}, \mathbf{8 , 1 1}$. Spores.

3. Alga, possibly related to Vaucheria De Candolle.

4. Zygospore, perhaps of a desmid.

6. Large tetrahedral spore.
9. Group of spores.

10. Optical section of a fern sporangium.

12. Fern sporangium with annulus. 
v. S. GEOLOGICAL SURVEY

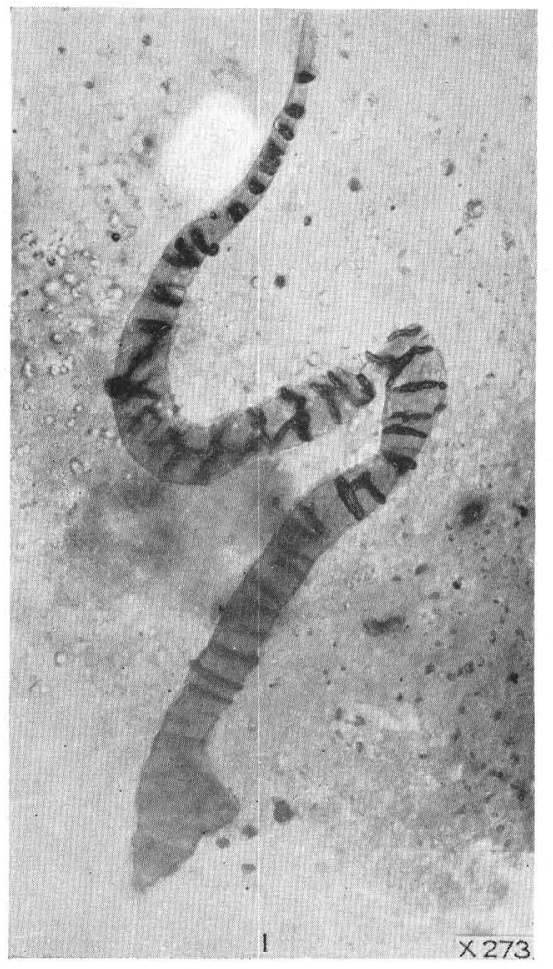

PROFESSIONAL PAPER 168 PLATE 24

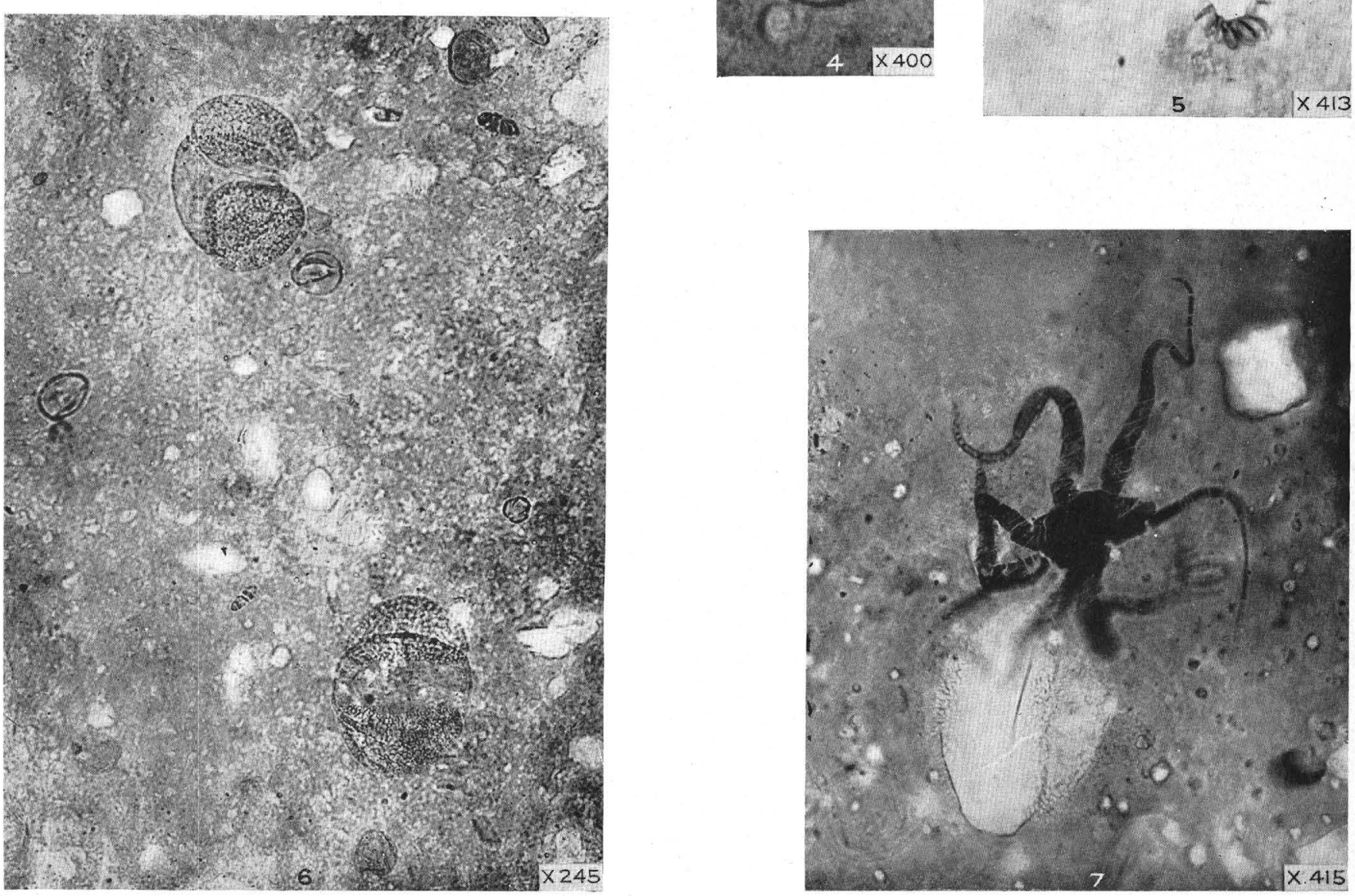

MICROFOSSILS OF THE OIL SHALE OF THE GREEN RIVER FORMATION

1. Peristome tooth? of one of the Bryales.

2. Transverse section of bark.

4. Pollen similar to that of Quercus prinus.
5. Spiral thickening of a tracheid.

\%. Stellate plant hair? 

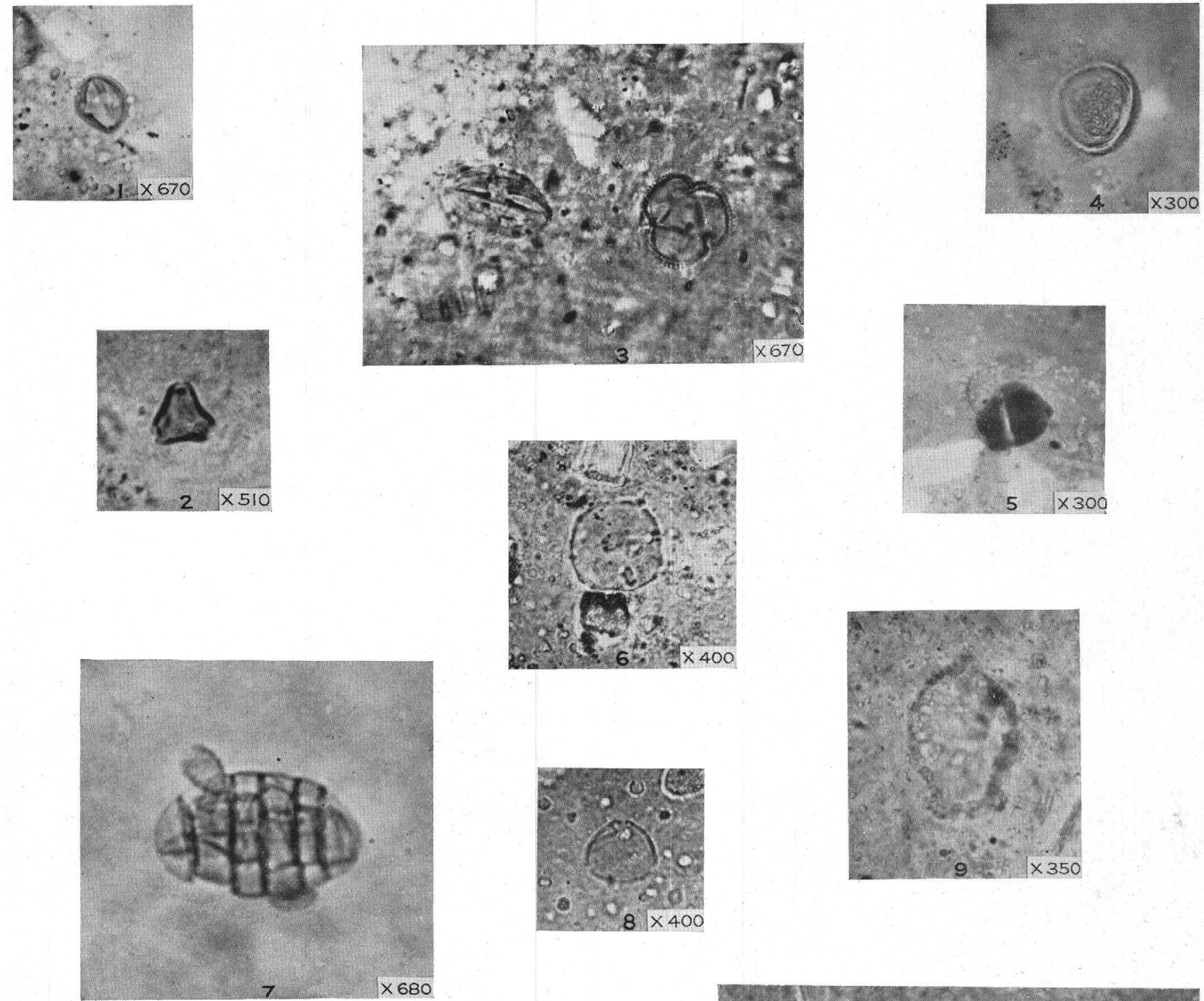

$\times 680$
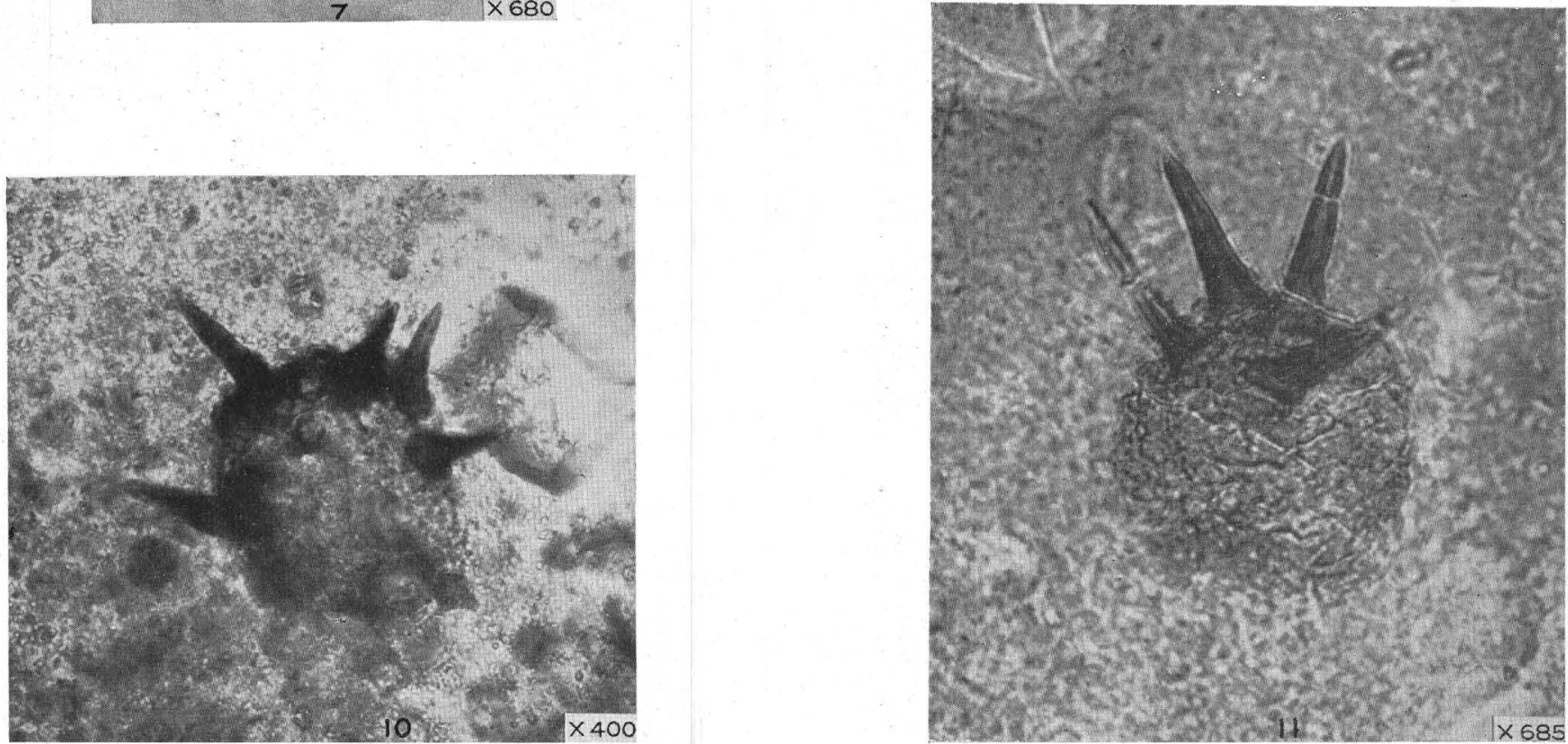

MICROFOSSILS OF THE OIL SHALE OF THE GREEN RIVER FORMATION

1. Pollen similar to that of the Umbelliferae.

very large apertures.

3. Trilobate spinose pollen grain.

4. Magnolia type of pollen.

6. Citrus type of pollen.
\%. Quadrula minuta Bradley, n. sp.

8. Tupelo type of pollen.

9. Difflugia calcifera Bradley, n. sp.

10. Euglypha robusticornis Bradley, n. sp., individual with 5 spines.

11. Euglypha robusticornis Bradley, n. sp., individual with 4 spines. 


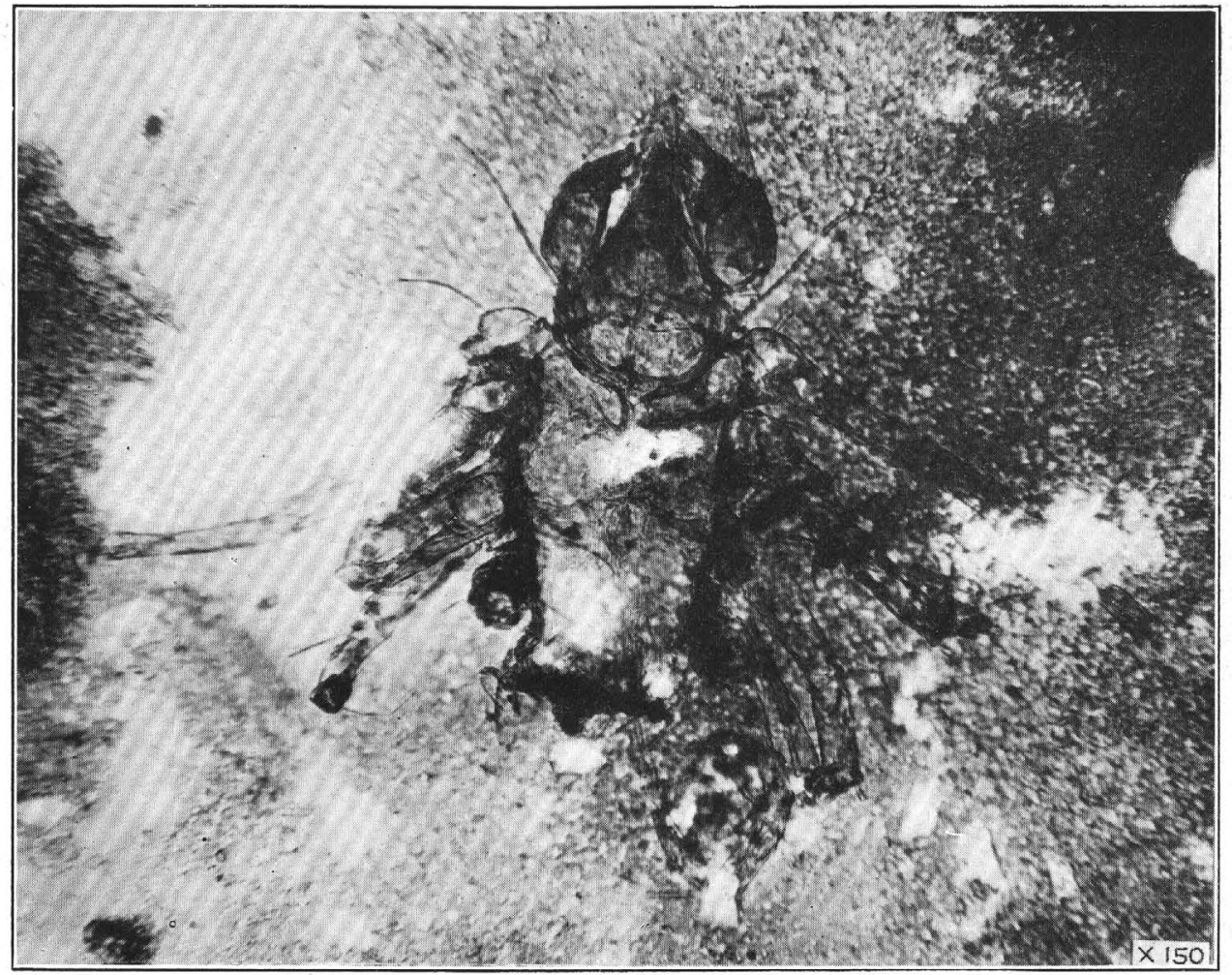

A. A predaceous mite Belonging to the Chelytidae



$B$. SPECIMEN SHOWN IN $A$ ENLARGED SO AS TO SHOW DETAILS OF HEAD PARTS

Microfossils of the Oil Shale of the Green River Formation. 

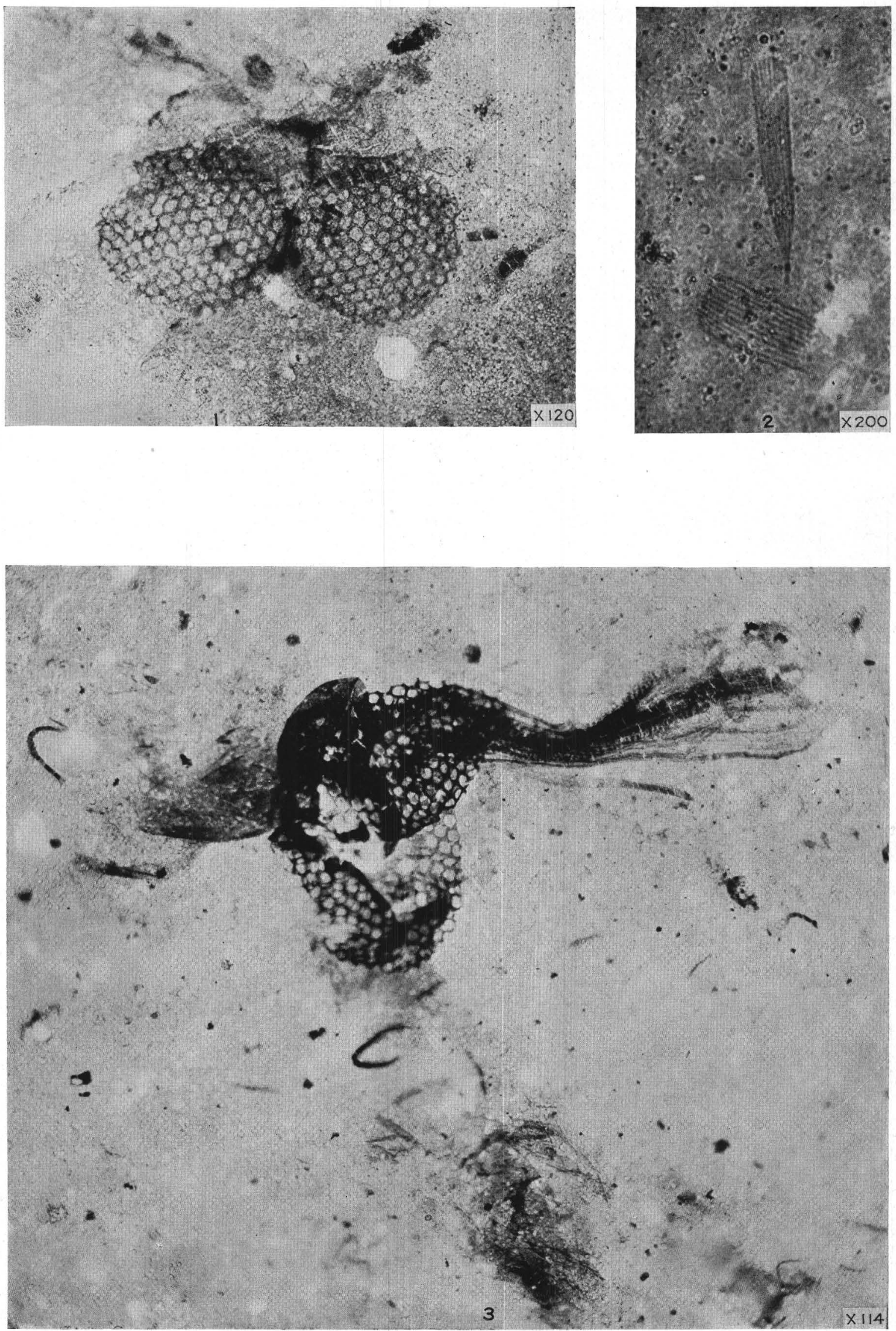

MICROFOSSILS OF THE OIL SHALE OF THE GREEN RIVER FORMATION

1. Eyes of a minute adult insect.

2. Wing scales of Culicidae?
3. Insect eyes and wings. 
U. S. GEOLOGICAL SURVEY
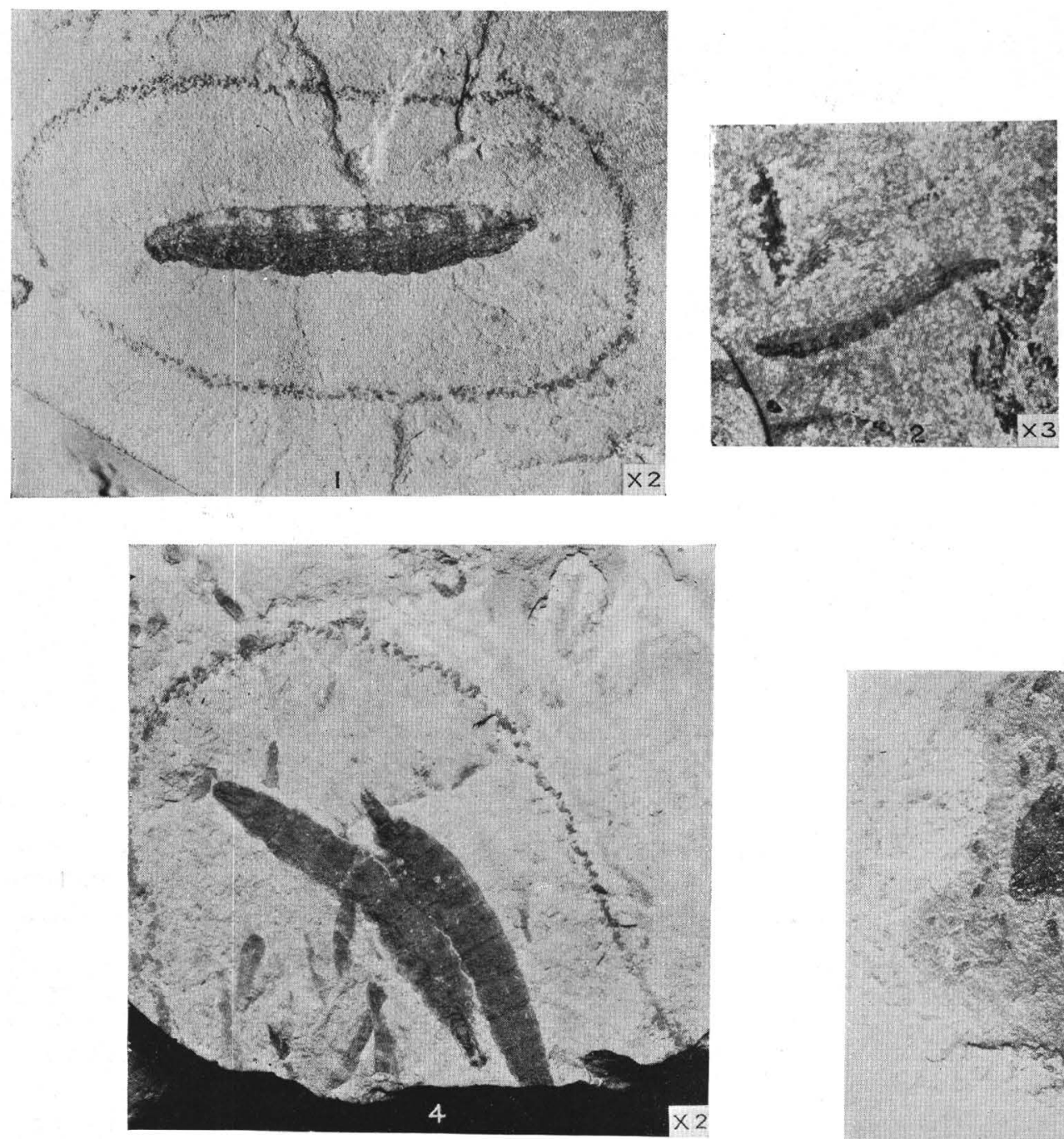

PROFESSIONAL PAPER 168 PLATE 28
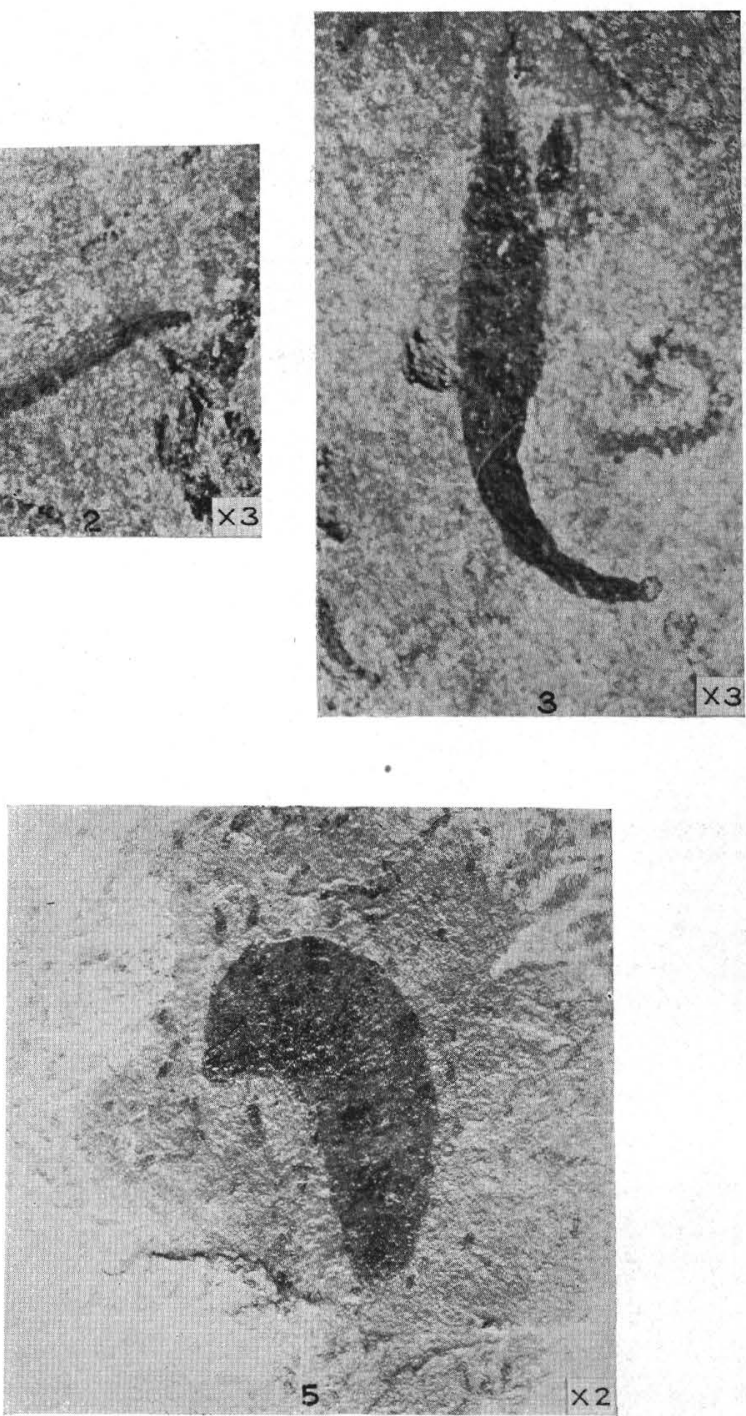
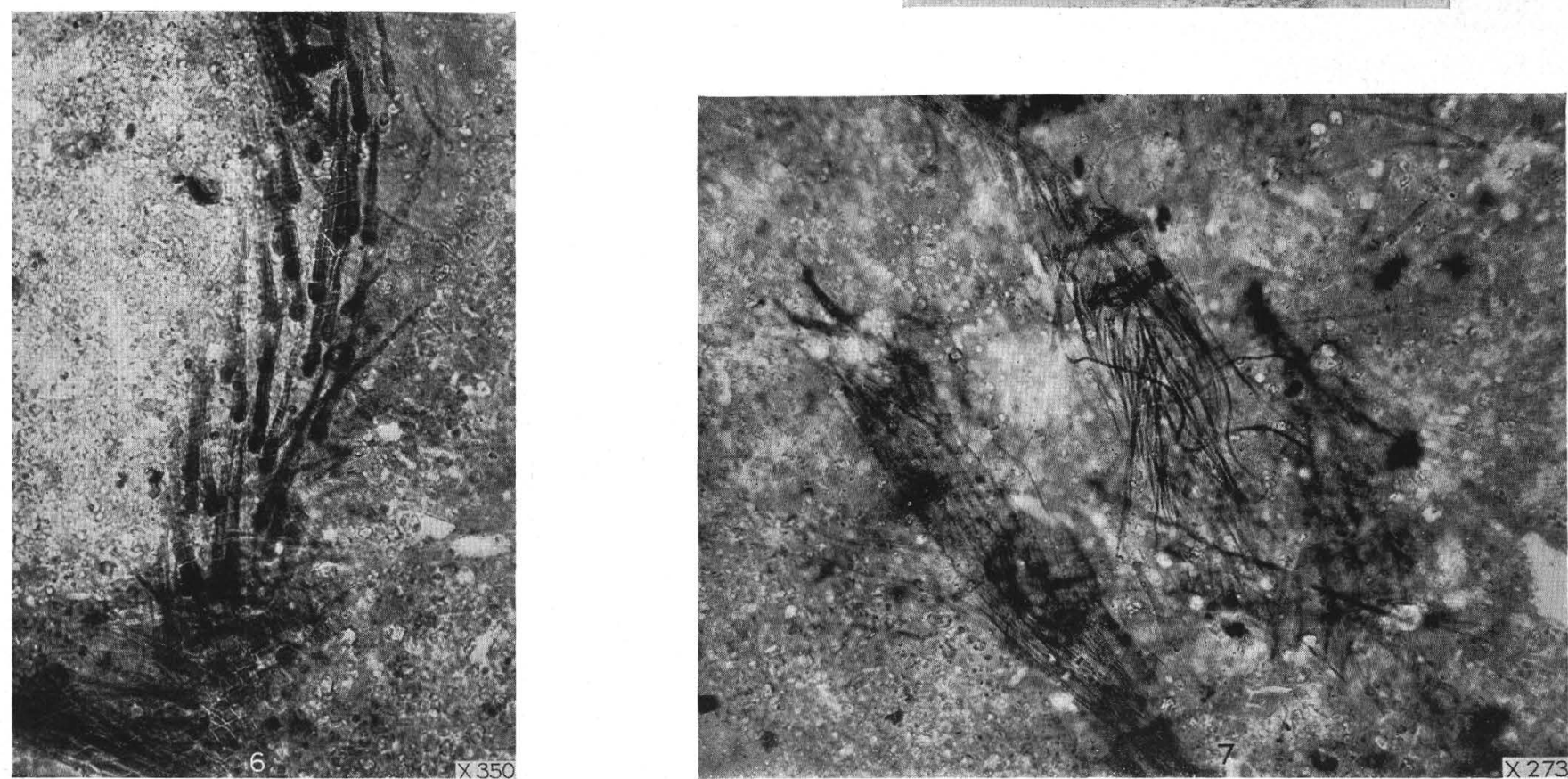

MICROFOSSILS OF THE OIL SHALE OF THE GREEN RIVER FORMATION

1. Larva of Tabanidae.

3. Larva of Chironomidae.

5. Larva of Lithohypoderma sp.
6. Stiff, bristlelike hairs of an insect.

4. Larvae of Syrphidae.

6. Stiff, bristlelike hairs of an insect. 
species, B: arhiza Borzi, which is $\mathbf{3 0}$ to $\mathbf{4 0}$ microns in diameter, is too small. Furthermore, as Prof. Gilbert Smith ${ }^{18}$ has pointed out to the writer, neither $E$. viridis nor $B$. arhiza would be expected far out in a lake like the ancient Uinta Lake. Eremosphaera is generally found in sphagnum bogs associated with desmids, and only one fossil of the Green River microflora might conceivably be interpreted as a desmid. (See pl. 23, fig. 4.) Botrydiopsis arhiza is a distinctly terrestrial alga.

Occurrence: The individuals are plentiful in the oil shale of the Green River formation, but the best ones were found in a sample of oil shale collected by $\mathrm{E}$. G. Woodruff from Asphalt Tunnel, about 2,300 feet above the base of the formation, in sec. 1, T. 7 S., R. 98 W., Garfield County, Colo.

\section{Family aUtosporacraE \\ Genus TETRAEDRON Etitzing}

Tetraedron sp. of. T. regulare var. torsum (Turner) Brunnthaler Plate 21. Figure 6

Tetraedron sp. cf. T. regulare var. torsum (Turner) Brunnthaler. Bradley, Centralbl. Mineralogie, Abt. B, No. 5, pp. 185186, 1929; Torrey Bot. Club Bull., vol. 56, p. 424, 1929

This alga shows a remarkable resemblance to the living Tetraedron regulare var. torsum. It is finely preserved and shows no shrinkage cracks. It is brownish orange-colored, and although clear and translucent it is somewhat darker than the groundmass, which ranges from reddish orange-colored to light lemon-yellow. The alga appears to be perfectly homogeneous, and all differentiation between the cell wall and contents has disappeared.

Occurrence: In a sample which upon distillation yielded 44 gallons of crude oil to the ton, collected by D. E. Winchester from a bed of black pyritiferous thinbedded oil shale in the Oil Shale Mining Co.'s quarry, sec. 27, T. 7 S., R. 100. W., Garfield County, Colo.

Genus cozrastrom Nägeli

Coelastrum? sp. cr. C. verrucosum Reinsch

Plate 21, Figure 5

Pediastrum sp. Davis, Nat. Acad. Sci. Proc., vol. 2, p. 116, 1916. Coelastrum? sp. cf. C. verrucosum Reinsch (or Pediastrum sp.). Bradley, Torrey Bot. Club Bull., vol. 56, p. 424, 1929.

This group of cells, which Davis regarded either as a Pediastrum or a member of a closely related genus, is probably. a Coelastrum, and Professor Smith ${ }^{18}$ pointed out its similarity to $C$. verrucosum Reinsch. According to this interpretation the group of eight cells represents a flattened and partly fragmented coenobium whose cells were more or less rounded and irregularly lobed. The individual cells of $C$. verrucosum, according to Reinsch, ${ }^{19}$ are 0.0097 millimeter in diameter. Those of

16 Personal communication, January, 1928.

10 Reinsch, P. F., Contribationes ad floram algarum aquae duleis Promontorii Bonse Spei: Linnean Soc. London Jour., Botany, vol. 16, p. 238, pl. 6, fig. 3, 1877. the fossil measure about 0.01 millimeter. But the irregular lobes on the cells of the fossil are apparentdy more rounded and larger in proportion to the size of the: cell than the irregular wartlike prominences on the cells of $C$. verrucosum. Nevertheless, in number, size, and, general aspect the cells are nearly enough like those of $C$. verrucosum to warrant the suggestion that the fossil is probably a species of Coelastrum comparable to $C$. verrucosum.

Occurrence: In a \$ample of oil shale collected by E. G. Woodruff from Asphalt Tunnel, about 2,300 feet above the base of the formation, in sec. $1, \mathrm{~T} .7 \mathrm{~S}$., R. 98 W., Garfield County, Colo.

\section{Order ULOLRICHAIES \\ Family ULOTrichacear \\ Genus morospora Thuret}

Microspora sp. cr. M. pachyderma (Wille) Lagerheim

Plate 21, Figure 7

Microspora sp. ef. M. pachyderma (Wille) Lagerheim. Bradley, Centralbl. Mineralogie, Abt. B, No. 5, pp. 186-187, 1929; Torrey Bot. Club Bull., yol. 56, pp. 424-425, 1929:

This alga, which is represented in the microflora of the Green River formation by a single fragment, is very close to $M$. pachyderma in filament structure, cell shape, and dimensions. The filament of the fossil is about 16.5 microns in diameter, and the cells average 13.5 microns in diameter and 20 microns in length. Pascher ${ }^{20}$ gives the dimensions of $M$. pachyderma as 9 to 12 microns wide and one to two times as long as wide.

The color of this fossil is unusual. It is pale lemonyellow and almost transparent, whereas most of the algae in the oil shale are reddish yellow, reddish orangecolored, or dark reddish brown. This color suggests that the plant is not much bituminized. The color is very close to that of the pollen' grains and waxy spore exines and might perhaps indicate that the living plant. had a different composition from most of the others associated with it.

Occurrence: This specimen was found in an unlabeled microtome section in the collection of C. A. Davis. The thin section is clearly oil shale from the Green River formation, but the locality is unknown.

\section{Family CHABTOPHORACRAE \\ Genus \$TIGEOQLONIU Ktitzing}

Stigeoclonium? sp. or. S. Iubricum (Dillwyn) Katzing

$$
\text { Plate 22, Figure } 1
$$

Stigeoclonium? sp. cf. S. lubricum (Dillwyn) Kützing. Bradley, Centralbl. Mineralogie, Abt. B, No. 5, pp. 187-189, 1929; Torrey Bot. Club Bull., vol. 56, p. 425, 1929.

It is not at all certain that this fragment of a branching alga belongs here. Tho few of its characters are known to be sure, in the first place, whether it is a

20 Pascher, A., op. cit., Heft 6, p. 152, 1914. 
member of the Chlorophyceae or the Cyanophyceae. However, it is placed here provisionally because its manner of branching and the size and shape of the cells are so strongly suggestive of $S$. lubricum. The cells are quadrate or cask-shaped and range in diameter from about 7 to nearly 10 microns. Hazen ${ }^{22}$ gives the diameter of the branchlets of S. lubricum as 6 to 7 microns and the diameter of the principal filaments as 14 to 16.5 microns. The fossil, which is unusually large compared with other specimens of the microflora, also resembles the blue-green alga Capsosira Kützing.

Occurrence: In a sample of oil shale collected by E. G. Woodruff from Asphalt Tunnel, about 2,300 feet above the base of the formation, in sec. 1, T. $7 \mathrm{~S}$., R. 98 W., Garfield County, Colo.

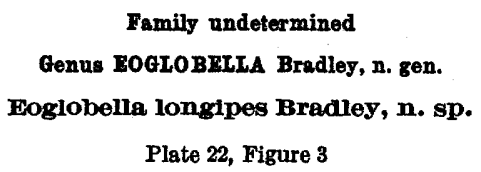

Thallus of definite shape, radially symmetrical, consisting of a single spherical cell to which are attached four equally spaced, greatly elongated cylindrical appendages. These are apparently single cells that are enlarged and flattened where they join the globular cell and tapered to a rather blunt conical point at the distal end. They arise from the globular cell a little below the equator and diverge slightly downward. The globular cell is about 38 microns in diameter; the appendages are about 6 microns in diameter and range in length from 115 to about 145 microns. The characters of the genus will also serve to define the species.

This organism does not resemble any living algae so far as the writer is able to judge. The name was suggested by C. A. Davis and appears on the labels of his photomicrographs. Only a single specimen has been found.

Type: The type, which is also the genotype, is a photomicrograph taken for Charles A. Davis. The negative, No. 3 , is filed in the photographic laboratory of the United States Geological Survey, Washington, D. C.

Occurrence: In a sample of oil shale collected by E. G. Woodruff from Asphalt Tunnel, about 2,300 feet above the base of the formation, in sec. 1, T. $7 \mathrm{~S}$., R. 98 W., Garfield County, Colo.

\section{ONCLASSIFIED FORMS}

Plate 22, Figure 4.-This alga apparently has the general vegetative characters of the Siphonales. The fronds are continuous, without dissepiments except perhaps at the junction of the stem and branches, but at those places the fossils are too opaque to make out

${ }^{22}$ Hazen, T. E., The Ulothricaceae and Chaetophoraceae of the United States: Torrey Bot. Club Mem., vol, 11, p. 196, 1902. the internal structure. Except for the minute size and the absence of roots, the fronds, which are clearly differentiated into stem and foliaceous branches, resemble species of Caulerpa Lamouroux, which is merine. The stolon was apparently horizontal and either rested : on the bottom or was shallowly buried, for the branches all arise from one side of it. The branches have a variety of shapes: some are relatively broad at the base and taper uniformly to a point; others are narrow at the base, broaden distad, and terminate in a blunt point; a few have rounded tips; and still others, usually short ones, are filiform with very acute tips. The branches are about 5 microns thick, but they were probably originally somewhat thicker. They range in length from about 83 to 675 microns. The broadest foliaceous branches are about 33 microns wide, but the filiform branches are not more than 8 microns. Both the branches and the stolon are homogeneous and excessively cracked by shrinkage. Apparently the membranaceous tissue was firm and tough. The branches are dark reddish brown but translucent, whereas the stolon is opaque.

Occurrence: Two complete plants and many isolated branches have been found in the oil shale. Most of these were found in thin sections cut from a sample collected by E. G. Woodruff from Asphalt Tunnel, about 2,300 feet above the base of the formation, in sec. 1, T. 7 S., R. 98 W., Garfield County, Colo. A few were found in sections cut from a sample of oil shale collected by D. E. Winchester at an unknown locality along Parachute Creek, Garfield County, Colo.

Plate 22; Figure 2.-This closely agglomerated mass of cells probably represents a member of the Chroococaceae, perhaps either Aphanocapsa Nägeli or Microcystis Kützing. Yet in one part of the mass the cells appear to be clearly united into filaments that show repeated dichotomous branching. In this respect they resemble certain species of the green alga Chaetophora Kützing.

Occurrence: In a sample of oil shale collected by E. G. Woodruff from Asphalt Tunnel, about 2,300 feet above the base of the formation, in sec. 1, T. $7 \mathrm{~S}$., R. 98 W., Garfield County, Colo.

Plate 23, Figure 3.-Apparently this cystlike cell grew upon the filament. The texture, color, and shrinkage cracks of the two parts appear to be identical and strengthen the impression that the fossil consists of a nonseptate filament to which is attached a large spherical cell. If this interpretation is correct the fossil has some of the characters of the Siphonales, and the large spherical cell suggests the oogonium of Vaucheria De Candolle.

Occurrence: In a sample of oil shale collected by E. G. Woodruff from Asphalt Tunnel, about 2,300 feet above the base of the formation, in sec. $1, T$. $7 \mathrm{~S}$., R. 98 W., Garfield County, Colo. 
Zygospore of desmid? (pl. 23, fig. 4).-This delicate fossil may possibly be the zygospore of a desmid. Its appendages are too short for it to be the perithecium of a powdery mildew.

Occurrence: Asphalt Tunnel, about 2,300 feet above the base of the formation, in sec. 1, T. 7 S., R. 98 W., Garfield County, Colo.

\section{BRYOPHYTA AND PTERIDOPHYTA}

Spores, sporangia, annuli, and scattered fragments of tissues of mosses and ferns are also found in the oil shale and in chert concretions. These the writer feels entirely unqualified to classify. Photomicrographs of some of the better preserved of them, together with brief descriptive notes on the spores, are included in this report for the sake of completeness. In the titles of a few the writer has suggested comparison with certain large groups of living plants.

\section{MOSS AND FERI SPORES}

Plate 23, Figure 5.-Exine thick, translucent, brownish yellow, rather coarsely scabrous and somewhat obscurely reticulate. No lines of rupture are discernible.

Occurrence: Chert concretion from a bed of oil shale about 1,300 feet above the base of the formation, in sec. 19, T. 5 S., R. 96 W., Garfield County, Colo.

Plate 23, Figure 2.-A large tetrahedral spore with a thick rigid exine and prominent episporic ridges along the interfacial angles. Elsewhere there is either no epispore or it is so thin as to be indistinguishable from the exine. The surface is minutely granular, almost smooth. The color is light orange.

Occurrence: Asphalt Tunnel, about 2,300 feet above the base of the formation, in sec. 1, T. 7 S., R. 98 W., Garfield County, Colo.

Plate 23, Figure 6.- Several of these microspores have been found. They are clear deep yellow, and all are finely preserved except for a few shrinkage cracks. The exine is very thick and perfectly smooth, and the lines of dehiscence are long and sharply defined. The diameter of the spore measured from the middle of one side through the center to the opposite angle is 61 microns. Renault ${ }^{23}$ described tetrahedral spores from a Russian boghead from Kourakino that are identical with these.

Plate 23, Figure 7.-An ellipsoidal spore with a thick scabrous epispore, which is not notably thickened along the lines of rupture and which is without ridges or spines. The color is strong reddish orange.

Occurrence: Asphalt Tunnel, about 2,300 feet above the base of the formation, in sec. 1, T. 7 S., R. 98 W., Garfield County, Colo.

Plate 23, Figure 1.-These perfectly smooth, spherical spores, which are pale yellowish orange-colored and translucent, are fairly common in oil shale from

\footnotetext{
23 Renault, B., Sur quelques microorganismes des combustibles fossiles: Soc.ind. min. St.-Etienne Bull., 3d ser., vol. 13, p. 1036, 1899.
}

various parts of the formation. They are of very nearly the same color and index of refraction as the structureless organic matter and so do not photograph well. The lines of dehiscence, however, are plainly. visible.

Occurrence: Asphalt Tunnel, about 2,300 foet above the base of the formation, in sec. 1, T. 7 S., R. 98 W., Garfield County, Colo.

Plate 2S, Figure 8.-This spore has a rather thin exine but a well-developed epispore, which is distinctly and coarsely reticulated with low but sharply defined episporic ridges. It is obviously broken and empty. This resembles the spores of some lycopods.

Occurrence: Chert concretion from a hard ostracodebearing shale about 140 feet above the base of the formation in sec. 27, T. 11 S., R. 10 E., Duchesne County, Utah, along the road from Castlegate to Duchesne.

Plate 23, Figure 9.-Spores of this sort are fairly common in the oil shale. This group of them shows particularly well the differentiation between the exine and epispore, especially the central spore, which is cut longitudinally. The exine and contents of that spore have shrunk away from the epispore. The spores are reniform and slightly flattened, suggesting that they were united in a tetrad. The exine is thick and rigid and is sheathed with a thick epispore, which is ornamented with high ridges and coarse conical and truncate conical spines. The spines are rather openly distributed over the surface. These spores resemble spores of some of the Marchantiales.

Occurrence: Asphalt Tunnel, about 2,300 feet above the base of the formation, in sec. 1, T. 7 S., R. 98 W., Garfield County, Colo.

Plate 23, Figure 11.-This spore has a thick rigid exine and an epispore which is ornamented with thickly set, sturdy conical spines. Locally the epispore is thickened but not in ridges. Lines of rupture are not discernible. The color is dark reddish orange. This specimen resembles the spores of some of the Marchantiales.

Occurrence: Asphalt Tunnel, about 2,300 feet above the base of the formation, in sec. 1, T. 7 S., R. 98 W., Garfield County, Colo.

Plate 23, Figure 12.- Several fern annuli have been found in the oil shale. One photographed by Davis is shown in Winchester's latest bulletin. ${ }^{24}$ The annulus illustrated in the present report, however, is still in place on the sporangium. The cells within the sporangium have disappeared, and the space is now filled with chalcedonic quartz. Presumably this is the sporangium of a leptosporangiate fern.

Occurrence: Chert concretion from a hard bed of ostracode-bearing shale about 140 feet above the base of the formation, in sec. 27, T. 11 S., R. 10 E., Duchesne County, Utah.

24 Winchester, D. E., Oil shale of the Rocky Mountain region: U. S. Geol. Survey Bull. 729 , pl. $7, C, 1923$. 
Plate 28, Figure 10.-This fossil is apparently an optical section of a sporangium. It shows plainly a number of cells whose dark granular contents have been preserved. There is apparently no annulus on the sporangium.

Occurrence: Chert concretion from a hard bed of ostracode-bearing shale about 140 feet above the base of the formation, in sec. 27, T. 11 S., R. 10 E., Duchesne County, Utah.

Plate 24, Figure 1.-This tapered filament strongly resembles the tip of an outer peristome tooth of one of the Bryales.

Occurrence: Asphalt Tunnel, about 2,300 feet above the base of the formation, in sec. 1, T. 7 S., R. 98 W., Garfield County, Colo.

\section{SPERMATOPHYTA GYMUTOSPERMAE}

The gymnosperms are represented in the oil shale only by the pollen of Pinus. Notes and photographs by C. A. Davis published in Winchester's bulletin ${ }^{25}$ record the occurrence of Picea and Pinus pollens. His photomicrograph of Pinus pollen is reproduced in this report as Plate 24, Figure 6. The writer has not been able to establish to his own satisfaction the presence of Picea pollen, though it is likely enough present. Pine pollen, as might be expected, is widely distributed in the oil shale, and most of it is very finely preserved. Most grains are lemon-yellow, clear, and of so nearly the same index of refraction as the structureless organic matter that it is often most difficult to discern them.

\section{AITGIOSPERMAE}

Davis ${ }^{26}$ also recorded the occurrence of pollen and fragments of tissues of angiosperms in the oil shale. He mentions also bark cells. His photomicrograph of a group of bark cells is reproduced in this report as Plate 24, Figure 2. As fragments of the tissues of higher plants are extremely rare in the oil shale their state of preservation is perhaps worthy of pasing note. Hence some notes on these bark cells, a spiral tracheid which the writer found, and some stellate plant hairs are included here.

\section{Transverse section of bark}

Plate 24, Figure 2

The fragment consists of a few layers of typical flattened, prismatic cork cells whose walls are much thickened secondarily. On the convex side of the strip are a few layers of thin-walled cells, much compressed and imperfectly preserved. These appear to be remnants of the cork cambium. A thin layer of poorly defined tissue on the other side may represent some of the bark. Owing to suberization and an adsorption of tannins, the secondary thickening of

26 Winchester, D. E., op. cit., p. 32, pl. 7, A.

20 Idem, p. 32. cork and bark cells becomes very resistant to decomposition and persists long after the purely cellulosic tissues have been destroyed. The middle lamella of: cork cells is usually lignified. Renault ${ }^{27}$ describod, two varieties of Micrococcus paludis which he found to be especially common in the woody tissues in peats; the variety $a$ he found attacking most frequently the thickening of cell walls, and the variety $\beta$ was most frequent in the median layers. He also found ${ }^{28}$ that when the constituents of lignites were in a very advanced state of disorganization the bark was usually reduced to the flattened cork cells.

The fragment of bark from the oil shale shows a stage of disorganization apparently similar to that described by Renault. The middle lamellae have almost entirely disappeared from the cork cells. Microbian activity very probably accounts for such a selective destruction. Unfortunately Davis's thin section from which this photograph was taken has been lost, and it is useless to look for the traces of bacteria, such as corrosion pits, at this magnification. At least it is evident that the median layers of the cell walls must have been destroyed after the bark strip was entombed in the organic ooze, or it would not have retained its organization. The suberized secondary thickenings were little affected by the process, but they have been so much compressed, by mechanical action or shrinkage, that the lumen is visible in but fow of the cells, and in these it is represented by a mere longitudinal slit.

Occurrence: Asphalt Tunnel, about 2,300 feet above the base of the formation, in sec. 1, T. 7 S., R. 98 W., Garfield County, Colo.

Spiral thickening of tracheld

Plate 24, Figure 5

This fragment represents a conducting vessel of a vascular plant. Only the strongly humified spiral thickening remains; the thinner and probably less lignified cell walls have disappeared in the maceration through which the original tissue must have passed. The fragment is dark reddish brown but still translucent. If the color and opacity may serve as indicators, it has apparently reached about the stage of carbonization of similar plant tissues in woody lignites.

Occurrence: Locality unknown; the fossil was found in an unlabeled microtome section of Green River oil shale in the collection of C. A. Davis.

\section{stellate plant hair?}

Plate 24, Figure 7

These minute fossils seem most likely to be stellate plant hairs, despite the fact that no point of attachment or stalk can be discerned on them. The leaves

${ }^{27}$ Renault, B., Sur quelques microorganismes des combustibles fosilles: Soe ind. min. St.-Fitienne Bull., 3d ser., vol. 13, p. 892, 1899.

${ }^{29}$ Idem, p. 945 . 
of at least two vascular plants, Viburnum alnifolium ${ }^{29}$ and Marrubium peregrinum, ${ }^{30}$ have stellate hairs comparable to these fossils. Some of the peltate scales from the petals of Thespesia populnea also resemble these fossils rather closely. ${ }^{31}$ All the plant hairs have definite cell walls, and no trace of this structure can be made out in the fossils. There remains the possibility that these forms are unicellular algae unlike any known species.

\section{Pollens}

Pollens in great number and diversity occur in the oil shale, and many of them show their structural characters with fair clarity. If these pollens could be surely referred to their proper genera they would shed much additional light upon the flora of the Green River epoch. Unfortunately the morphology of pollens is imperfectly known, and consequently they have never been accurately correlated with the classified plants. Mohl ${ }^{32}$ classified a great many pollens according to their superficial rather than fundamental characters, and in consequence, as Wodehouse ${ }^{33}$ points out, many of his groups widely separate species of the same genus and also associate species of totally unrelated plants. However, Wodehouse's studies ${ }^{34}$ established the fact that there are certain fundamental characters of pollen grains, such as the structure and shape of the germ apertures and textures of exines, which are constant within certain orders or families. These fundamental characters may also be found in other families, but taken with the superficial characters, such as ornamentation, number and arrangement of folds, and shape and size of the grains, they show a profound and intimate phylogenetic relationship of the pollens with the plants. In the hope that the morphology and relationship of pollens to the classified plants will be known these pollens are described in notes that make clear as many as possible of the characters that Wodehouse found to be of taxonomic value.

Doctor Wodehouse is now making a systematic study of the pollens found in the writer's thin sections of oil shale and chert from the Green River formation and expects to publish later the results of his investigations.

Some comparisons of the pollens with those of living plants are suggested here, but they are not to be regarded as rigorous determinations. The comparisons are based in part upon examination of fresh pollens

${ }^{20}$ McCleery, E. M., Stellate hairs and peltate scales of Ohio plants: Ohio Naturalist, vol. 7, No. 3, pp: 51-56, pl. 6, figs. 25, 26, 1907.

${ }^{20}$ Schmidt, Carl, Vergleichende Untersuchungen über die Behaarung der Labiaten und Boragineen (Inaug. Diss., Univ. Freiburg, Berlin), p. 39, fig. 7, 1888.

11 Yoangman, W., and Pande, S. S., The epidermnd outgrowths of the genera Thespesia and Gossypium: Annals of Botany, vol. 43, p. 722, pl. 19, fig. 25, 1929.

a2 Mohl, Hugo von, Sur la structure et les formes des graines de pollen: Annales sci. nat. bot., vol. 3, p. $148,1835$.

as Wodehouse, R. P., Morphology of pollen grains in relation to plant classifcation: New York Bot. Garden Jour., vol..27, p. 145, 1926.

* Idem, pp. 145-151. and in part upon Young's key for the determination of pollens, ${ }^{35}$ which aims simply to group similar pollen grains and thus indicate more or less closely their relationships.

Plate 24, Figure 3.-Apparently there are threo equally spaced germ apertures in this pollen. The thin smooth walls of the grains are notably thickened around the apertures. Grains like this are very plentiful in the oil shale and chert concretions.

The writer compared these grains with fresh Thuja pollen, and they seem to be identical in every respect.

Plate 24, Figure 4.-The three distinct germ apertures on these pollen grains are in slight bosslike elevations which are equally spaced around the periphery. The walls are comparatively thin except near the bosses, where they are somewhat thickened.

The writer compared these grains, which are not common, with fresh Quercus pollens. They are very similar to $Q$. prinus.

Plate 25, Figure 1. - In these pollens there are two pores midway on the grain and two on the inner edges of the longitudinal folds. The pair on the folds are shown by the semicircular indentations. The exine is thick, rigid, and finely granular except between the longitudinal folds, where it is smooth and apparently thin. The longitudinal folds are high and prominent and extend the full length of the grain.

According to Erdtman ${ }^{36}$ most of the Umbelliferse, a family of herbaceous plants that includes Carum carri (caraway), have pollen grains like these. They are very common in many beds of oil shale and in the chert concretions.

Plate 25, Figure 3.-The single pore of this trilobate grain is near the center of the grain, in a slight depression within a short groove between two of the rounded lobes. The grains are thickly beset with fine cylindrical spines. There are apparently no folds, and the exine seems to be fairly thick and rigid.

These grains are common in the oil shale and in chert concretions. They do not find a place in Young's classification, nor has the writer been able to find any to compare them with.

Plate 25, Figure 4.- This grain is a large depressed ellipsoid that has on one side a clear, highly refringent lunate margin. The exine is very thick, strong, and conspicuously scabrous. No pores were observed.

It runs out in Young's key to the magnolia type. These grains are only slightly larger than those of Liriodendron sp. They are not plentiful in the oil shale.

Plate.25, Figure 5.-Only part of this grain shows in the photograph. It is spherical, apparently without pores, and ornamented with rather openly spaced long

as Browne, C. A., and Young, W. J., Chemical analyses and oompositions of American honeys, including a microseopic study of honey pollen: U. B. Dept. Agr. Bur. Chemistry Bull. 110, pp. 70-93, 1908.

${ }^{36}$ Erdtman, G., Beitrag zur Kenntnis der Mikrofossilien in Torf und Bedimenten: Arkiv för Botanik, Band 18, Halfte 4, pp. 2-3, fig. 3, 1924. 
conical spines. The exine has a microgranular texture and does not appear to be thick.

This falls in Young's mallow type, but it is slightly smaller than the pollen of most Malvaceae. These grains are not plentiful in the oil shale.

Plate 25, Figure 2.-This somewhat triangular pollen grain has three very large germ apertures situated at the angles. The exine is thick, rigid, and smooth. No folds are discernible.

According to Dr. A. E. Longley ${ }^{37}$ of the Bureau of Plant Industry, this pollen resembles pollen of some of the Primulaceae. Very few of these grains have been found in the Green River formation. These grains also resemble the pollen of Betula sp., Corylus sp., and Ostrya carpinifolia, according to the figures of Erdtman. ${ }^{38}$

Plate 25, Figure 8.-The four germ pores which are located at the angles of this tetrahedral pollen are small. The exine is thin and perfectly smooth.

It resembles closely the tupelo type of Young but is somewhat smaller. It also agrees fairly well with the pollen of Corylus sp. figured by Hesmer. ${ }^{39}$ These grains are uncommon in the oil shale. .

Plate 25, Figure 6.-This pollen grain is subquadrate, and the small germ apertures are at the corners. They are marked by slight depressions and slight thickenings of the wall. The exine is thin and perfectly smooth.

This runs out to the citrus type in Young's key. Only one such grain has been found. It may, however, be a diagonal section of the pollen of Myriophyllum spicatum according to Erdtman's figure. ${ }^{40}$

\section{FAUNA OF THE OIL SHALE}

The microfauna of the oil shale is not large. It includes representatives of the Protozoa and Arthropoda. Fragments of insects very greatly predominate. The most remarkable member of this fauna is a finely preserved mite.

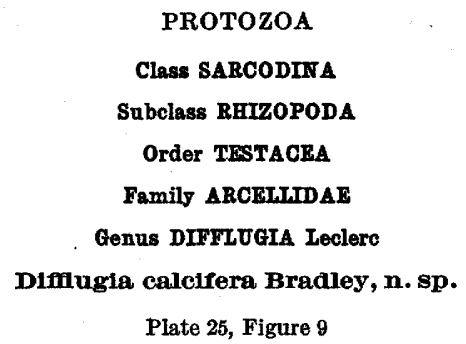

Shell pyriform, narrowed to a short cylindrical neck; mouth terminal, large, and apparently circular; fundus obtusely rounded; shell thin and composed of a compact mosaic of minute calcite grains.

This rhizopod might with some justification bave been referred to $D$. pyriformis Perty, from which it

\footnotetext{
" Oral communication, March, 1927.

98 Erdtman, G., op. cit., p. 7, pl. 2, figs. 50-56.

${ }^{20}$ Hesmer, H., Mikrofossilien in Torfen: Palaeont. Zeitschr., Band 11, Nr. 3, fig. 11, p. $246,1929$.

60 Erdtman, G., op. cit., pl. 2, fig. 88.
}

differs only in the kind of material used for the shell and in size. It is considerably smaller than most species of Diffugia.

Type: The type is in a thin section of a chert concretion cut for the writer and marked $25 / 3 \mathrm{c} \cdot$ It is in the writer's collection at the United States Geologioal Survey, Washington, D. C.

Occurrence: In a small black pyritiferous chert concretion from a bed of hard carbonaceous ostracodebearing shale about 140 feet above the base of the formation, in sec. 22, T. 11 S., R. 10 E., Duchesne County, Utah.

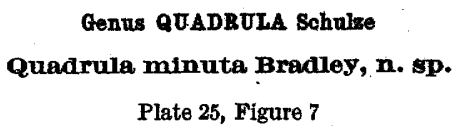

Shell ellipsoidal, composed of distinct rectangular transparent plates regularly arranged in tiers transverse to the major axis of the shell, plates at either end notably larger and more triangular in outline. By changing the focus of the microscope the outline of the plates on the other side of the shell may be clearly.seen through the upper layer of plates, and the small oral opening at the right may be discerned. Near the posterior end half a row of plates has been lost; only those on the lower side of the shell show at that place in the figure. The shell was probably once chitinoid and may even now be unchanged, as it is not marred by shrinkage cracks, nor is it colored reddish brown like so many of the oil-shale microfossils. No trace of the sarcode mass remains. The fossil is represented by three individuals.

Except for its minute size (28 microns long and 16 microns wide) it might be included in the living species Q. symmetrica (Schulze). The smallest individual of that species mentioned by Leidy ${ }^{41}$ is 80 microns long and 40 wide, and the largest 140 microns long and 96 wide. The fossil species resembles most closely in shape an individual of $Q$. symmetrica figured by Conn, ${ }^{42}$ but it is less than one-third the size of that individual.

Type: The type is in a microtome section cut by Charles A. Davis and marked "No. 7." It is in the writer's collection at the United States Geological Survey, Washington, D. C.

Occurrence: Oil shale of the Green River formation, Uinta Basin of Colorado and Utah, exact location unknown.



Shell spherical, 40.2 to 61.5 microns in diameter, composed of slightly overlapping elliptical translucent plates whose major axes are parallel to the axis of the animalcule; plates probably consisted originally of chiti-

41 Leidy, Joseph, Fresh-water rhizopods of North America: U. S. Ceol. and Ceog Survey Terr. Rept., vol. 12, p. 143, 1879.

4 Conn, W. H., The Protozos of the fresh waters of Connecticut: Connectient Nat. Hist. and Geol. Survey Bull. 2, pl. 3, fig. 20, 1905. 
noid membrane. Shell armed at the top with four or five exceedingly stout spines each of which tapers uniformly to a rather acute point; they appear to be hollow and thick walled. The spines range in length from about 30 to 80 microns in different individuals. On all specimens of the fossil species the spines are confined to a smaller area of the fundus than those of living species, in which they usually arise from the sides more or less remote from the top.

None of the specimens are so oriented as to show the mouth clearly. Two, however, present side views, and in both of these the oral end is devoid of denticulate marginal plates. The opening appears to be a little more than one-third of the diameter of the shell.

This protozoan is represented by four specimens, all rather well preserved. The shells are pale lemonyellow to brownish yellow and translucent, but the spines are dark reddish brown and nearly opaque. The shells are remarkably little crushed, and only the spines show breaks due to shrinkage after entombment.

Type: The type is in a microtome section cut by Charles A. Davis and marked "Loc. P, sp. 1a, box 6, slide 2." It is in the writer's collection at the United States Geological Survey, Washington, D. C.

Occurrence: The type specimen came from an unknown locality in either Colorado or Utah. It is possible that the letter $P$ refers to Winchester's location designated by the same letter in sec. $22, \mathrm{~T} .6 \mathrm{~S}$., R. $95 \mathrm{~W}$., Garfield County, Colo. ${ }^{43}$ Other individuals are recorded by Davis's photomicrographs from Asphalt Tunnel, about 2,300 feet above the base of the formation, in sec. 1, T. 7 S., R. 98 W., Garfield County, Colo.

\section{ARTHROPODA \\ Class ARACHIIDA \\ Order ACARIDA \\ Family ChelYTtoak \\ Plate 28}

According to Dr. H. E. Ewing, ${ }^{44}$ of the United States National Museum, this mite is clearly a member of the Chelytidae, but the smaller parts of the palpi by means of which the genera are distinguished are concealed, so that it can not be compared with any existing form now known. The living members of this family are predaceous and feed upon other mites. Only this one individual has been found in the oil shale of the Green River formation, and so far as Doctor Ewing is aware this is the first fossil mite to be reported from this hemisphere. It was found by C. A. Davis, under whose direction it was photographed. The thin section containing it was not among those which came to the writer when he began this study. The photographic negatives, Nos. 109 and 110, are filed in the photographic laboratory of the United States Geological Survey.

\footnotetext{
49 Winchester, D. E., Oil shale of the Rocky Mountain region: U. S. Geol. Survey Bull. 729 , pp. 54-55, pl. 8, 1923 .

4s Oral communication, May, 1928 .
}

The oil shale from which the thin section was made was collected by E. G. Woodruff from Asphalt Tunnel, about 2,300 feet above the base of the Green River formation, in sec. 1, T.5 S., R. 98 W., Garfield County, Colo.

\section{Class ImswoTA}

Fragments of insects are very common in many beds of rich oil shale. Most plentiful are pieces of the chitinous skins or sclerites. Although many are apparently smooth or finely granular, others bear hairs or spines. In some seetions the spines are still arranged in tiers. (See pl. 18.) The mono-, di-, and polyspiculated spines are characteristic of dipterous larvae and particularly of the Oestridae or bot flies. (See pl. 28, fig. 5.)

Much more remarkable and hardly less common are the remains of the eyes of minute but adult insects. (See pl. 27, figs. 1, 3.) Only the chitinous integument remains; the facets have apparently been decomposed. These eye remains commonly occur in pairs, and many of them are still attached to parts of the insect. These parts include antennae, wings, sclerites, hairs, and unidentifiable smooth pieces of the skin. H. G. Dyar, ${ }^{45}$ of the. United States National Museum, thought that these insects were rather highly specialized, perhaps as much so as the Hymenoptera. The wings of some are apparently paired and the antennae fork from a common cylindrical pillar.

David White ${ }^{46}$ has long regarded these peculiar netlike fossils as the eyes of insects, but apparently Davis ${ }^{47}$ believed that they were plants, for in his notes he describes them as plants of a low order. (See p. 38.)

The minute scales from the wings of insects are plentiful in some thin sections of oil shale. (See pl. 27, fig. 2.) These scales range in length from 61 to about 98 microns and in maximum width from 11 to 18 microns. The striae are pale yellowish brown, and the membrane between them is transparent and very difficult to differentiate from the straw-colored organic matrix in which the scales are embedded. Probably the membrane is colorless. The striae are spaced about 1.5 microns apart, are essentially parallel, and end abruptly against the margins near the pedicle. The margins of the scales are entire except at the distal end, where the striae terminate in acute points, thus making the scale arcuate. The pedicles are cylindrical, not enlarged at the base, and rather long. Although the scales are intermediate between the generalized hairlike type and the broad, digitate scales like those of certain Lepidoptera they incline more toward the generalized type, because they are narrow. They resemble most nearly the scales on the wings of mosquitoes (Culicidae), of which four

\footnotetext{
45 Oral commumication, March, 1927.

to Oral communication, 1924.

47 Davis, C. A., notes cited in Winchester, D. E., Oil shale of the Rocky Mountain region: U. S. Geol. Survey Bull. 729, p. 32, pl. 7, B, 1923.
} 
species, according to Winchester, ${ }^{48}$ have already been found in the Green River formation.

Occurrence: These scales, together with fragments of larger scales whose structure is identical, are rather plentiful in thin sections cut from a sample of oil shale collected by D. E. Winchester from a bed of black pyritiferous thin-bedded oil shale in the Oil Shale Mining Co.'s quarry in sec. 27 , T. 7 S., R. $100 \mathrm{~W}$., Garfield County, Colo. This sample yielded 44 gallons of oil to the ton.

In addition to these there are also a few short sections of legs showing the joints and pieces of cuticlebearing hairs. (See pl. 28, fig. 6.) Plumose appendages are not rare. Some of these have stout, rigid bristles, but the bristles of others are fine and almost hairlike. (See pl. 28, fig. 7.)

\section{Order DIPTERA}

Though the larvae of flies are plainly not microfossils and though they have not been given the detailed study they deserve, a few of them are included in this report because they are so abundant in certain zones in the Green River formation, especially in most of the rich oil shales. Dr. Charles T. Greene, of the Bureau of Entomology, has examined the larvae illustrated here and determined the families, and for some the genera, to which they belong.

\section{Family CHIronomidate \\ Plate 28, Figure 2}

Most of the members of this family of minute flies have aquatic larvae. They inhabit the bottom oozes of lakes even to great depths, for their oxygen requirements are apparently low. Fossil chironomid larvae are plentiful at certain horizons in the upper part of the Green River formation. The one illustrated was found about 2,200 feet above the base of the formation, in sec. 16, T. 5 S., R. 95 W., Garfield County, Colo. Adult members of this family have been found on the bedding planes of certain marlstone beds, and three of them (Chironomus septus Scudder, $C$. depletus Scudder, and $C$. patens Scudder) have already been described.

\section{Family STRATIOMYIDAE \\ Genus ODONTOMYIA \\ Odontomyla sp. \\ Plate 28, Figure 3}

These larvae aquatic and breathe through the tail spiracles while suspended from the surface film. Many of them pupate in the mud close to shore. In the Green River formation these larvae are abundant and are associated with chironomid, mycetophilid, oestrid, and tabanid larvae and unidentified adult insects. The Odontomyia larva shown here was collected from a bed about 2,200 feet above the base of

(B Winchester, D. E., op. cit., p. 28. the formation, in sec. 16, T. 5 6., R. 85 W., Garfield County, Colo. No adult species of Odontomyia have been described, but species of four related genera of this family have been described.

\section{Family TaBantoaz \\ Plate 28, Figure 1}

To this family belong the horse flies, gad flies, deer flies, and the like. The larvae are predaceous, and many are aquatic. In the Green River formation these larvae are fairly plentiful. Specimens were collected from a bed of marlstone about 1,500 feet above the base of the formation, in sec. 26 , T. 3 S., R. 99 W., Garfield County, Colo. At this place they are associated with the larvae of Tabanidae, Oestridae, and Mycetophilidae, various adult insects, and a few leaves. Adults of this family apparently have not been described.

\section{Family SYRPIIDAE \\ Plate 28, Figure 4}

The larvae of this family live in putrefying vegetable matter. Their - well-preserved remains abound in certain organic marlstone beds of the Green River formation. Those illustrated here were collected from a bed in the upper part of the formation, in the south half of T. 2 S., R. 95 W., Rio Blanco County, Colo. Adults of five genera of this family have been described.

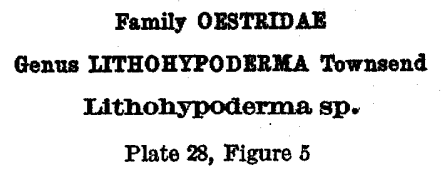

Genotype: Musca ascarides Scudder, U. S. Geol. and Geog. Survey Terr. Rept., vol. 3, p. 551, 1890.

These larvae are among the most interesting fossils. found in this formation. Scudder regarded them as probably members of the Muscidae, despite their remarkable similarity to certain Oestridae, particularly Hypoderma sp. Later Cockerell ${ }^{49}$ examined new collections of these larvae and referred them to the living genus Hypoderma, though he said that they should probably constitute a new genus of Oestridae. Townsend ${ }^{50}$ pointed out several distinct differences between the fossil larvae and Hypoderma and founded the new genus Lithohypoderma. Scudder's reluctance to place these larvae in the Oestridae ${ }^{51}$ was apparently influenced somewhat by the difficulty he found in conceiving the conditions under which so many parasitic larvae could have become embedded in the lacustrine mud, for he said:

It would seem improbable that so large a number of oestrid larvae could be found, when the only way in which they could have reached their present condition would be through, the droppings of animals affected by the bots standing in the water.

40 Cockeren, T. D. A., Some American fossil insects: U. S. Nat. Mus. Proa, vol. 51, pp. 91-92, 1916.

so Townsend, C. H. T., Lithohypoderma, a new fossil genus of oestrids: Insecutor inseitiae menstruus, vol. 4, Nos. 10-12, pp. 128-130, 1916.

si Seudder, S. H., op. cit., p. 551 . 
Cockerell ${ }^{62}$ also expressed a little of this doubt when in referring to the remark just quoted from Scudder he said: "This, however, is quite possible if they infested gregarious animals, though we must agree that the infestation seems to have been remarkably heavy."

The idea that these spinose larvae lived in tumors under the skin of mammals, like the modern species of Hypoderma, and that their occurrence in the lake beds is merely accidental and the result of their having fallen from their hosts while the hosts were drinking from the lake seems to the writer quite beyond any reasonable possibility. The larvae are far too abundant and occur in continuous beds over far too large areas to have come from that source: In general, wherever they are found they are numerous. Scattered individuals are rather rare. On certain bedding planes so many larvae overlap one another as to make up continuous thin laminae of chitinous material. But on most bedding planes of the shale in the flylarvae zone of the Green River formation the larvae are very closely spaced or touch one another. (See pl. 2, B.) Furthermore, these beds that contain so many oestrid and other dipterous larvae are continuous over many square miles. (See pl. 3.) Accordingly, it seems to the writer utterly inconceivable that so many animals could have been so badly infested with bots as to drop the countless numbers of them that occur in these beds. Moreover, these larvae-bearing beds have been examined carefully at many places in Colorado and Utah, and no mammalian remains of any kind have yet been found in them, although in general watering places are particularly liable to have about them the bones of the animals that drink there. Again, if these maggots came from mammals the ooze into which they fell must have been thoroughly trampled so that all traces of original lamination were effaced; but, nearly all the larvae-bearing beds are rather thinly laminated, and indeed in some beds the layers of rock a few millimeters thick that lie between laminae containing the larvae have distinct varves. For these reasons the conclusion that the larvae of Lithohypoderma spent at least a part of their larval life on the lake bottom in decaying organic ooze seems inescapable. As the writer noted in an earlier paper, ${ }^{53}$ this hypothesis is materially strengthened by the intimate association of Lithohypoderma with the larvae of Stratiomyidae (Odontomyia sp.), Syrphidae, Mycetophilidae, Tabanidae, and Chironomidae, many of whose living species are aquatic and live among decaying vegetable matter. The syrphid larvae are particularly noteworthy, for they are saprophytic.

The taxonomic significance of the larval habitat of Lithohypoderma must be left to students of Diptera.

62 Cockerell, T. D. A., op. cit., p. 92.

5 Bradley, W. H., A contribution to the origin of the Green River formation: Am. Assoc. Petroleum Geologists Bull., vol. 9, p. 261, 1925.
It may mean that Lithahypoderma really belones to another family and that this is merely an examplo of convergent evolution, or it may mean that these; really forerunners of Hypoderma but were aquatic free-living forms that either fed upon the decaying organic matter or were predaceous and fed upon other ooze-dwelling organisms. The writer is inclined to regard the second hypothesis as more probable. According to this idea these free-living forms acquired their parasitic habit later in geologic time.

The Lithohypoderma larvae illustrated here (pl. 28, fig. 5) were collected from a bed about 1,100 feet above the base of the formation on the west side of Piceance Creek, in sec. 11, T. 1 N., R. 97 W., Rio Blaneo County, Colo. The group of oestrid larvae shown in Plate 2, $B$, were collected from a bed about 875 feet above the base of the formation in the canyon of the White River, in sec. 27, T. 9 S., R. 25 E., Uintah County, Utah.

\section{INTERPRETATION AND SIGNIFICAITCE OF THE MICROFOSSILS}

The fossil bacteria in the oil shale of the Groen River formation are too doubtful to be of any value. The fungi, however, suggest an interpretation of certain phases in the formation of oil shale. The abundance of fungi, particularly the delicate filaments, indicates that they probably grew in place, and the fact that some of them seem to be forms that lived upon decaying plants suggests that they grew on the surface of the organic ooze while it was exposed to the air for brief periods of time. Renault ${ }^{54}$ observed that woody peats which had remained for a short time above the water table contained a great abundance of fungus filaments and spores, whereas those which had been continuously submerged contained relatively few fungi. It seems logical to assume that the relation between the number of fungi and exposure to air might be similar also in deposits of organic ooze. Yet it should be emphasized that the evidence which the fungi bring to the interpretation of the origin of the oil shale is tenuous. Moreover, at least some of the fungi (Saprolegniae) were probably aquatic.

Blue-green algae apparently dominated the algal flora of the ancient Green River lakes. In general algae of this class find their optimum temperature several degrees higher than that of the other algae. Furthermore, a great many of them flourish in stagnant and more or less foul waters. Hence they are peculiarly adapted to live in shallow stagnant pools. Indeed, they are so characteristic of the shallow old-age lakes of Denmark that Wesenberg-Lund ${ }^{55}$ calls that stage of the life histories of lakes the "cyanophycean stage."

4 Renault, B., Sur quelques microorganismes. des combustibles fossiles: Boo. ind. min. St.-Etienne Bull., 3d ser., vol. 13, p. \$02, 1899.

s6 Wesenberg-Lund, C., cited by Lenz, F., Bchlammschichtung in Binnenseen: Naturwiss. Wochenschr., vol. 18, p. 330, 1921. 
The absence of diatoms from the oil shale of the Green River formation is astonishing, but its significance is ambiguous. It may be that fresh-water diatoms do not go that far back in geologic time, or it may be that the lakes were too saline for them. According to Dr. Albert Mann, ${ }^{56}$ of the Carnegie Institution of Washington, who studied the diatoms from a core of Lake Lahontan beds, the diatoms became depauperate and finally disappeared at one or more stages in the lake's history when it was low and consequently saline. It seems doubtful, therefore, if diatoms ever lived in the ancient Green River lakes, for none of their tests have been found even in the limy and clayey beds associated with the oil shale, where there is little likelihood that the products of putrefaction of the organic matter have dissolved them all, as might perhaps have happened in the organic oozes.

The green algae suggest stages of the lake when the water was less saline and better aerated, but they do not provide conclusive evidence, for their range of habitats is too great.

The unclassified algae are particularly interesting for their exotic forms, but they contribute little else.

Six of the algae described here seem from their structure and by comparison with similar-shaped living algae to have been plankton organisms. Eight others seem to have been attached to substrata and must therefore have lived either on the bottom or upon other plants. One, Eoglobella longipes, may have been either a free-living or a bottom-dwelling form.

The great abundance of the remains of rather large fly larvae (Oestridae, Stratiomyidae, Syrphidae, Mycetophilidae, and Tabanidae) in the oil shale indicates a probable moderate depth of water. Certain living members of these families (Odontomyia) frequent chiefly the very shallow water close to the shores of ponds and lakes. The living aquatic members of the Tabanidae also generally frequent shallow pools. The larvae of Syrphidae and Mycetophilidae live in decaying vegetable débris, and as the other larvae (Lithohypoderma) are associated with all these forms and occur in rock of exactly the same sorts they probably were accustomed to the same habitat, despite the utterly different life habits of their nearest living relatives (Hypoderma). The midge-fly larvae (Chironomidae), however, have no significance whatever as depth indicators, for their living representatives abound alike in the shallowest pools and at the bottoms of really deep lakes. The parts of minute adult insects are of little use in interpretation, for they might have fallen into a water body of any sort. Their fragmentary condition and the loss of all but the most strongly chitinized parts seem to indicate rather distinctly that they did not get stuck on exposed mud flats, like so many of the larger adult insects found in the marlstone. Forms caught in that

se Oral communication, 1922. way and covered quickly are characterized by the perfection of their preservation.

Pollens and spores were carried in by wind and so are erratically distributed through the deposit. Locally they are very plentiful. The shriveled condition of certain groups of pollen suggests that they fell upon a dried mud flat. Their possible relation to known types of plants shed a little additional light on the composition of the flora of the adjacent region. When the pollens and spores are better known they undoubtedly can add much information about the land flora of that region in the Eocene epoch.

\section{STRUCTURELESS ORGANIC MATTER}

The material here termed "structureless" is so designated to differentiate it from that with definite outline called here for the sake of brevity the figured organic material. It appears perfectly homogeneous, even at magnifications of 1,500 diameters, unless the light is reduced and slightly oblique, and then it appears somewhat flocculent. Its color in very thin edges of sections ranges from straw color to a faint reddishorange color, but in slices the thickness of ordinary thin sections most of it appears brownish or reddish orange.

Trager ${ }^{57}$ pointed out that there were two kinds of structureless organic matter, one optically active and the other not. He gave none of the optical properties; however. According to the writer's observations most of the structureless material is apparently isotropic. In a few sections two sharply differentiated sorts of optically active organic material were found. One is a clear, brilliant cadmium-yellow: This material has an index of refraction about equal to 1.61. It is not pleochroic but has sharply defined parallel extinction and birefringence a little higher than quartz. It is uniaxial negative. The structureless material of the other kind is clear reddish orange-colored and very slightly pleochroic, with the absorption greater in the plane normal to the bedding. Its index of refraction is a little less than 1.61 ; the extinction is shadowy and the birefringence feeble. The interference figure is vague but appears to be uniaxial or perhaps biaxial, with the value of $2 V$ very small.

Davis ${ }^{58}$ said that "the structureless material probably originated in a collection of plant débris which has by decomposition and the activities of bacteria and other microscopic organisms passed into a jellylike phase such as is to be found in certain kinds of modern peat deposits."

The evidence appears conclusive that the structureless material which makes up by far the greater part of the total organic matter of the Green River oil shale was derived from the partial putrefaction of aquatic

57 Trager, E. A., Kerogen and its relation to the origin of oil: Am. Assoc. Petroleum Geologists Bull., vol. 8, p. 309, 1924.

38 Davis, C. A., notes in Winchester, D. E., Oil shale in northwestern Colorado and adjacent areas: U. S. Geol. Survey Bull. 641, p. 165, 1916. 
organisms that grew in the lakes. The organic matter is most abundant in the center of the lake basin and diminishes in all directions toward the shore phases, from which it is practically absent. Aquatic microorganisms dominate the microflora and microfauna of the oil shale. Fragments of the tissues of higher land plants are exceedingly rare, though their spores and pollens are not uncommon. And finally, as the writer has pointed out in a previous paper, ${ }^{59}$ there is a remarkably close parallelism between the oil shale and recent lacustrine organic oozes or isapropels. This analogy with recent sapropel has lately been greatly strengthened by the results of a brief study of an algal ooze from a small lake near Reddick, Marion County, Fla. This ooze consists chiefly of fragmentary and complete blue-green algae belonging chiefly to the genera Gloethece, Aphanothece, Arthrospira, Microcystis, Phormidium, and Chroococcus. It also contains bacteria, diatoms, fungi, sponge/spicules, and pollens, as well as a fairly large proportion of structureless organic jelly. D. Stuart Mossom, ${ }^{60}$ assistant State geologist of Florida, collected some of this material more than three years ago and permitted it to dry out very slowly in a warm place. It contracted greatly and dried down to a dense grayish-black substance fully as hard as oil shale, which it resembles in every way save that it is more brittle. Moreover, it is very significant that in the drying no perceptible odor was given off, showing that decomposition had been very greatly retarded, if it had not entirely ceased. Thin sections of the dried material, pieces of which Mr. Mossom was kind enough to supply, are identical in most respects with oil shale. Even the structureless organic material has the same appearance and nearly the same optical properties as the structureless matter in some sections of the Green River oil shale. Furthermore, the hardened Florida sapropel will burn with a smoky flame. The smoke, however, smells quite unlike that of burning oil shale. Evidently the two materials are not precisely alike, yet the similarities are very remarkable and suggestive. Upon distillation this dried sapropel yields about 16 gallons of tarry oil to the ton.

The predominance of structureless organic matter in the oil shale of the Green River formation is in itself fair testimony of an active microbian decomposition. The partly decomposed organisms and particularly the large quantities of syngenetic pyrite or marcasite afford strong evidence of the extensive putrefaction of organic matter.

Mechanical and chemical actions, such as the mastication and digestion of the original material by bottom-living organisms, were probably also important factors in the disintegration of the organic matter. Saprophytic organisms, too, assisted in the decomposition.

w Bradley, W. H., A contribution to the origin of the Green River formation and its oil shale: Am. Assoc. Petroleum Geologists Bull., vol. 9, pp. 252-258, 1925.

w Oral communication, November, 1926.
In discussing the microbian decomposition of sepropelic matter, White ${ }^{61}$ says:

It appears that plant protoplasm, and in most case the gelatinous and mucous substances, which are less resistent to bacterial decomposition, quickly disintegrate, and later the cellulosic matter of the original cell membranes, whereas the waxy and waxy fat or "higher fat" products, the resinous exines, and the chitins are last to be lost.

White also believes ${ }^{62}$ that the animals in the ancient lakes contributed only indirectly to the organic deposits. The soft parts of animals are very rare in the oil shale. He says, however:

The products of the total. biochemical decomposition of the animal tissue may form part of the colloidal groundmass solution, and the decomposition derivatives, mingling with those of the plants, may contribute new compounds and impart new. qualities to the humic aggregate, thus making the derivative solution more distinctly bituminous.

To judge by analogy with the life societies in modern lakes, the production of zooplankton was very probably also large in the Green River lakes. Insect larvae were surely plentiful in some of the ooze beds, and probably nematodes were also. It seems reasonable that these organisms should have contributed some of the "fatty" constituents in the sapropel. Naumann ${ }^{63}$ demonstrated that the Entomostraca synthesize fats and thus may. account for a considerable fat production in lakes where they abound.

The preservation of so much organic matter must have been determined by a copious supply of the organisms, an effective check upon the microbian activity, and the absence of strongly oxidizing conditions. That the rate of supply of organisms far exceeded the rate of decomposition is obvious, - and from that it follows that the production of organisms within the lakes was large. The absence of strongly oxidizing conditions is amply proved by the quantity of syngenetic iron sulphide disseminated through the oil shale. But the means by which the microbian decay was held in check are less certain. White ${ }^{34}$ suggests that toxic humic solutions derived from the decomposition of the organic material impede the putrefactive processes and so conserve the material. Other factors, however, may have been equally effective. As the organisms decayed the material clearly passed over into a gel, which might have adsorbed large quantities of water and-held it so firmly that it was not available for bacteria. Hence the organic ooze might have become physiologically dry as soon as it gelatinized. It would then have been entirely unfavorable for bacteria. Potonié as called attention

et White, David, The carbonaceous deposits, in Twenhofel, W. H., Treatise on sedimentation, p. 291, 1926.

62 Idem, p. 293.

${ }^{63}$ Naumann, Einar, Einige Gesichtspunkte betreffs der Fettproduktion des Süsswasserzooplanktons: Archiv Hydrobiologie und Planktonkunde, vol. 13, pp. 307-312, 1922.

* White, David, The carbonaceous sediments, in Twenhofel, W. H., Treatise on sedimentation, pp. 289-294, 1926.

os Potonié, H., Die rezenten Kaustobiolithe und ihre Iagerstartten: K. preuses geol. Landesanstalt Abh., new ser., Heft 55, Band 1, p. 13, 1908. 
to the stability of sapropel after the first stage of putrefaction and said that he had kept it in an oozy or slimy condition in poorly corked bottles for years without detecting any odor of decomposition. This accords with Mossom's observation on the sapropel from Florida and with the writer's experience with some sapropel collected by C. A. Davis nearly 18 years ago. Biochemical studies of this material are much to be desired, and the results would probably elucidate many puzzling questions regarding the preservation of sapropelic material.

The asepticity of the gelatinous organic ooze explains the remarkable preservation of delicate organisms like algae and Protozoa. When these were mixed into the gel accidentally they were apparently mummified and, having escaped the biochemical stage were subsequently changed only by a slow process of bituminization, which evidently affected both the gelatinous organic ooze and its entombed microorganisms, spores, pollens, and fragments of animal and plant tissue. Späte ${ }^{66}$ gave a very concise definition of bituminization, which may be freely translated as follows:

Bituminization as well as coalification leads to an enrichment in carbon. But in coalification carbon is enriched at the expense of all the other components together, whereas in bituminization both carbon and hyrogen are increased in proportion to the other components, oxygen, nitrogen, and sulphur.

\section{PHASES OF UINTA LAKE DURING THE GREEN RIVER EPOCH}

Uinta Lake, the great Eocene lake in which the Green River formation of Utah and Colorado accumulated, may be pictured at its earliest stage as a very broad sheet of water flooding a large fluviatile plain, bounded by mountains or high hills except on the south, where the country must have been fairly low. This plain was built up of clay, silt, and sand brought down by streams from the surrounding mountains, and as the alluvial material is predominantly mudstone the basinward slopes must have been rather gentle. The mudstone and stream-channel sandstone beds make up the Wasatch formation and in the greater part of the basin are comparable to the youngest flood-plain deposits in Sacramento Valley, California, between Butte City and the Montezuma Hills, which according to Bryan ${ }^{67}$ consist chiefly of clay and silt with more or less braided stream-channel deposits of coarser sand and gravel. The gradient of the Sacramento River through this area is a little less than 1 foot to the mile.

If this gradient is assumed for the basin floor over which Uinta Lake first spread and if it is also assumed that the water was not more than 10 or 15 feet deep

Spate, Friedrich, Die Bituminierung, ein Beitrag zur Chemie der Faulschlammgesteine (Inaug. Diss, Friedrich-Wilhelms-Univ., Berlin), pp. 44-45, 1907; cited by Potonie, H., op. cit., p. 20, 1908.

Bryan, Kirk, Geology and ground-water resources of Sacramento Valley, California: U. S. Geol. Survey Water-Supply Paper 495, pp. 7, 10, 30, pl. 4, 1923. near the shores, where the algie reefs formad, theo the deepest parts of the lake-near the centerief ithe basin may have been as much as 50 or 60 foet deep. But other things being equal, lacustrine sedimentation would probably soon have lessened this relief on the lake floor, so that while the greater part of the basal member was being formed the lake bottom was nearly. level. On the other hand, the lake may have started as small ponds and backwaters along the stream courses in the alluvial plain and expanded very gradually, filling the basin and leveling up the plain as it grew, until finally a continuous lake opread over the entire plain from mountain flank to mountain flank.

In this great shallow lake algae flourished and built bedlike reefs that expanded broadly over the smooth lake floor. Fish, mollusks, crustaceans, and aquatic insect larvae were also plentiful in the lake, and turtles (Baptemys sp. and Echmatemys sp.), crocodiles, birds, and small camels, as well as myriads of winged insects, frequented the shores. Along some shores there were marginal swamps, which persisted for a considerable time and whose former positions are revealed now by thin beds of coal and carbonaceous mudstone. But this lake, despite its enormous area and slight depth, must have been is fairly stable water body with an outlet, for the writer estimates ${ }^{68}$ that some of the thicker algae reefs required at least 355 years to form. During that time only slight changes in water level, rate and manner of circulation, and rate of sedimentation could have occurred. Such changes would register in the growth layers of the reef. A considerably longer period when the lake overflowed is indicated by the composite reef near the divide between Douglas and Salt Creeks, Colo., which is 18 feet thick. Nevertheless it is possible that between these long periods of apparent stability in the early stages of Uinta Lake the overflow was intermittent. The prevalence of mud-cracked bedding planes and mud curls in some parts of the basal member supports this hypothesis. Yet complete desiccation probably was not even approached. At this stage Uinta Lake may have been entirely fresh, or it may have been comparable in relative permanence, depth, and content of dissolved salts to Goose Lake, Oreg., which contains about 1,000 parts per million of dissolved salts, rarely overflows, and although very shallow has never been known to dry up. ${ }^{60}$ Yet much more convincing evidence that the lake had an outlet is found in the absence of salt crystal molds from the Douglas Creek or basal member of the Green River formation.

The climate of the Green River epoch seems to have exerted a marked influence upon the fluctuations of

ob Bradley, W. H., Algae reefs and oolites of the Green River formation: U. 8. Geol. Survey Prot. Paper 154; p. 220, 1929.

${ }^{69} \mathrm{~W}$ aring, G. A., Geology and water resources of a portion of south-central oregon: U. S. Geol. Survey Water-Supply Paper 220, pp. 12, 38, 1808. 
Uinta Lake. In another report ${ }^{70}$ the writer has attempted rough quantitative estimates of several factors of this climate and concluded from the relative areas of Gosiute Lake (the ancient Green River Lake in Wyoming) and its hydrographic basin and from the fossil flora that the climate was characterized by cool, moist winters and relatively long, warm summers. Presumably the temperatures fluctuated rather widely from a mean annual temperature that was of the order of $65^{\circ} \mathrm{F}$. The rainfall also appears to have varied with the seasons and probably departed rather widely from a mean annual precipitation between 30 and 43 inches. The evaporation from the lake surface seems to have nearly balanced the supply of water from rain and the streams, for the lake level fluctuated repeatedly and apparently between wide limits. The seasonal distribution of the precipitation probably played a large part in determining this characteristic of the ancient lake. If, as the writer supposes, the greater part of the rainfall came during the winter, then the relatively long, hot summer would have been particularly favorable to evaporation. Thus at certain stages Uinta Lake may have overflowed during part of each wet season and then have contracted more or less during the dry season, so that, as the lake was rather shallow, large parts of the bottom were repeatedly left exposed. But at one stage the lake apparently did not overflow for a long time. During that stage the water became so saline that at times of exceptionally low levels salts crystallized out on the mud-cracked flats or below the surface of the wet mud. At times the deposition of salt was apparently cyclic. In the saline zone of the Green River formation thus produced the most common crystal cavities are those which were formed by glauberite(?) and anhydrite(?).

But between these stages characterized by extreme low lake levels occurred periods in which the lake seems to have maintained a persistently rather high level. The preservation of the varves in certain rocks of the Green River formation ${ }^{71}$ appears to indicate that while they were forming the lake was so.deep that the water was thermally stratified. While so stratified the water at the bottom of a lake is virtually stagnant. Only the water in the warm uppermost layer circulates and transports material for sedimentation. The supply of oxygen is soon exhausted from the stagnant bottom water, and so because of the decaying organic matter the bottom ooze becomes a strongly reducing medium that is distinctly unfavorable for most bottomdwelling animals. The original ooze of the varved rocks could not have supported an active population of worms, larvae, crustaceans and the like, for these organisms would surely have destroyed the delicate lamination. Moreover, the abundance of finely granular

\footnotetext{
T0 Bradley, W. H., The varves and climate of the Green River epoch: U. S. Geol. Survey Prof. Paper 158, pp. 93-95, 1929.

7 Idem, pp. 101-103.
}

primary pyrite also supports the hypothesis that these *? varved deposits accumulated under reducing conditions: such as prevail generally in the stagnent hypolimion, or lower stratum, of modern lakes that are themally stratified. Now, as not only marlstone but also beds of exceptionally rich oil shale contain varves and an abuat. dance of microgranular pyrite the two kinds of rocks must have accumulated under essentially' these same conditions of quiescence and stagnation. These conditions seem to imply that the water may have been 75 or 100 feet deep. ${ }^{72}$ The regularity of most of the oil-shale beds and their remarkable persistence over many square miles in the central part of the basin make it seem likely that the greater part of the high-grade oil shale in the Green River formation was formed in the relatively cool, stagnant hypolimnion of a lake that was deep enough for a thermal stratification of its water to persist for long periods of time.

On the other hand, it seems quite clear that some of the lenticular and irregular beds of oil shale, especially those that are mud cracked and brecciated and those that are full of salt-crystal cavities; must have been formed in very shallow water. These shallow-water bodies seem to have been residual pools or ponds left in depressions of the lake bottom at stages of extreme low level. They probably contained in solution an ample supply of nitrates accumulated from the decay of organic matter during the shrinkage of the parent lake. Dissolved salts must also have beeome concentrated in them. In short, they must have been exceedingly rich in the foodstuffs necessary to the production of vast numbers of organisms. Ward ${ }^{73}$ makes the following generalization about the life in lakes and ponds:

Purely temporary water bodies, such as pools that form in hollows after a heavy rain or in a wet season, develop little if any life. Such places on poor soil are most barren of all; the aquatic life increases with the fertility of the soil, the age of the water body, and the consequent accumulation of organic débris. Residual ponds, water bodies in which the drying out is more gradual and often incomplete and in which the central area may be protected from complete desiccation by vegetation or proximity to the general water level, afford conditions at the opposite extreme.

Conditions were evidently near the optimum in these shallow residual lakes of Green River time, for they had a tremendous production of aquatic organisms. In fact, the abundance of the organisms and consequently the large quantity of decaying organic matter must have given rise to strongly reducing conditions in these pools, comparable to those that prevailed in the stagnant hypolimnion when the water was deeper. At certain stages these pools perhaps approached playa conditions, though they could have been dry for only relatively very short intervals.

72 Idem, p. 103.

73 Ward, H. B., and Whipple, G. C., Fresh-water biology, p. 3, 1918. 
After the deposition of most of the oil shale the lake seems to have reverted nearly to the conditions that prevailed during its earlier stages, when the marlstone and low-grade fil shale of the basal member were formed. However, the central parts may have been even shallower than at first, as is suggested by the occurrence far out in the basin of mud cracks and fossil leaves and inwects. During this last stage the water level also fluctuated and the bottom was repeatedly exposed, so that the large mud flats were dried and and cracked. But sometimes apparently the water was withdrawn only for short intervals, for many bedding planes are uncracked, and yet they bear adult insects which, it seems, must have fallen on a wet mud flat, where they stuck until covered. Perhaps such temporary withdrawals were due to a steady wind that piled up the water on the opposite shore. Similar phenomena have been observed repeatedly in the shallow lakes of the West. For example, Waring reports that the north end of the Abert Lelve Buing so nearly level that a strong south wind forcent the water back nearly 2 miles. Leaves, flowns, stamvs and seeds were also found on these bedding plawes Locally, too, there are many small fish akelotons, apparently indicating that the fish were stranded:-

- A sudden but not large diastrophic change rejw. venated the streams in the vicinity of Uinta Lake so that they carried a great quantity of medium to coarse grained sand far out into the basin and formed a thick layer over the lake beds. Thus the deposition of the basal sandstone of the Bridger formation brought the lacustrine history of the Green Riter epoch to a close.

7 Waring, G. A., Geology and water resources of a portion of south-contral Oreqone J. S. Geol. Survey Water-Supply Paper 220, p. 38, 1908 


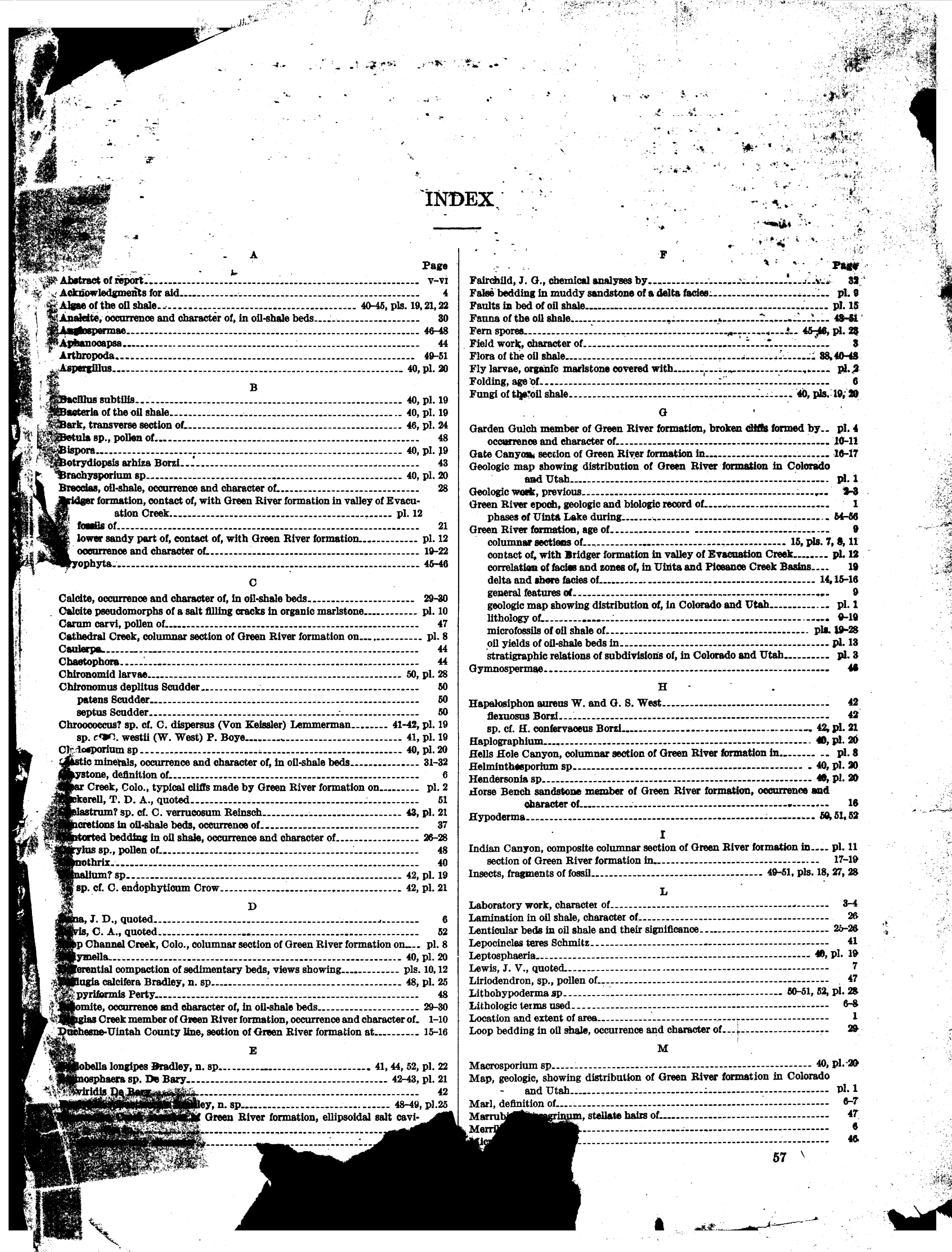




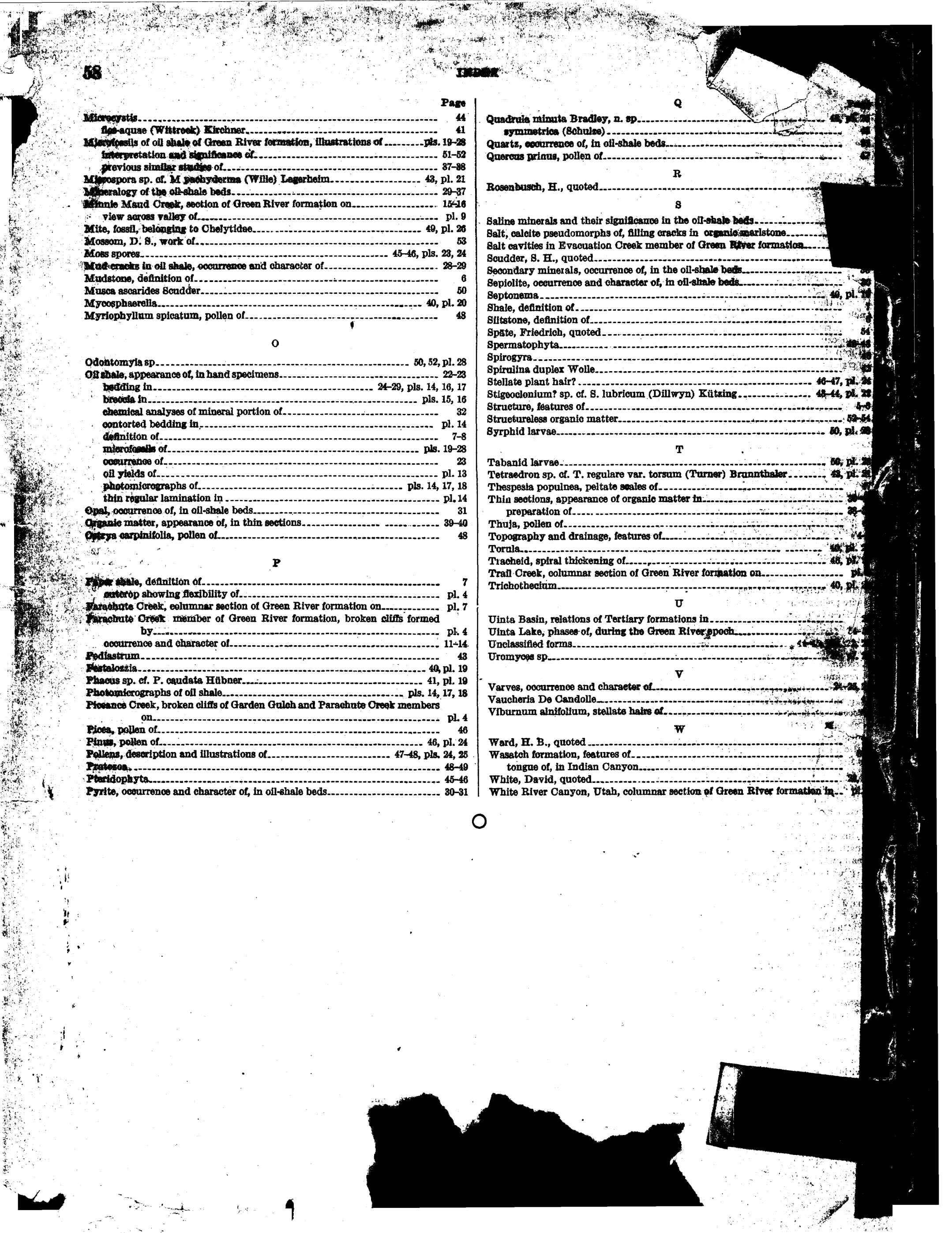

